University of Michigan Law School

University of Michigan Law School Scholarship Repository

1950

\title{
Survey of Metropolitan Courts: Detroit Area
}

Maxine Boord Virtue

Follow this and additional works at: https://repository.law.umich.edu/michigan_legal_studies

Part of the Courts Commons, and the State and Local Government Law Commons

\section{Recommended Citation}

Maxine Boord Virtue, Survey of Metropolitan Courts: Detroit Area. Ann Arbor: The University of Michigan Law School, 1950.

This Book is brought to you for free and open access by the Law School History and Publications at University of Michigan Law School Scholarship Repository. It has been accepted for inclusion in Michigan Legal Studies Series by an authorized administrator of University of Michigan Law School Scholarship Repository. For more information, please contact mlaw.repository@umich.edu. 


\section{MICHIGAN LEGAL STUDIES}

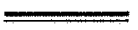 \\ SURVEY OF METROPOLITAN COURTS DETROIT AREA}

PUBLISHED UNDER THE AUSPICES OF THE UNIVERSITY OF MICHIGAN LAW SCHOOL (WHICH, HOWEVER, ASSUMES NO RESPONSIBILITY FOR THE VIEWS EXPRESSED) WITH THE AID OF FUNDS DERIVED FROM GIFTS TO THE UNIVERSITY OF MICHIGAN BY WILLIAM W. COOK. 


\section{MICHIGAN LEGAL STUDIES}

Hessel E. Yntema, Editor

Discovery Before Trial

George Ragland, Jr.

ToRTS In THE CONFLict of LAWS

Moffatt Hancock

The Amending of the Federal Constitution

Lester B. Orfield

Review of Administrative Acts

Armin Uhler

The Prevention of Repeated Crime

John Barker Waite

The Conflict of Laws: A Comparative Study

Volumes One, Two, and Three

Ernst Rabel

UnReported Opinions of the Supreme Court of Michigan I 836-I 843

William Wirt Blume, Editor

Problems in Probate Law: Model Probate Code Lewis M. Simes and Paul E. Basye

$$
\begin{aligned}
& \text { Soviet Civil LaW } \\
& \text { Volumes One and Two } \\
& \text { Vladimir Gsovski }
\end{aligned}
$$

Survey of Metropolitan Courts : Detroit Area

Maxine Boord Virtue 


\section{SURVEY OF METROPOLITAN COURTS DETROIT AREA}

PREPARED FOR

The University of Michigan LaW School AND

The Section of Judicial Administration of the AMERICAN BAR ASSOCIATION

BY

\section{Maxine Boord Virtue}

Of the State Bars of Michigan and Kansas

Formerly Research Associate, the University of Michigan

FOREWORD BY

IRA W. JAYNE

Presiding Judge of the Circuit Court of Wayne County, Michigan

Chairman of the Committee on Judicial Administration in Metropolitan Trial Courts of the Section of Judicial Administration of the American Bar Association

Ann Arbor

University of Michigan Law School 


\section{COPYRIGHT, I950}

BY

UNIVERSITY OF Michigan 
To my family this book is dedicated, and especially to John B. Virtue, my husband, to whom no man is an island. 


\section{Foreword}

T N ITS continuing study of the problems in its field, the Section of Judicial Administration of the American Bar Association came to realize that the conduct of judicial business in a big city differed from that of the onejudge court in smaller communities; that the former had little in common with the latter but the law-and even the application of that was sometimes quite different.

This feeling came to a head in 1947 when Judge Alfred P. Murrah was Chairman of the Section. He appointed the writer Chairman of a Committee on Judicial Administration in Metropolitan Trial Courts. As a beginning, this Committee requested the University of Michigan Law School to make a professional study of the problem. The faculty, through its research committee under Professor Lewis M. Simes, designated Professor Edson R. Sunderland to supervise the work. They employed Mrs. Maxine Virtue to conduct the survey. She is equipped with experience as a practicing lawyer and as a public servant with a background of scholarship.

Detroit was selected for the first study, not only for convenience, but because on general inquiry it has most of the problems characteristic of a metropolitan area. The judges and administrative staffs of each of the courts co-operated well. Such records and statistics as the courts had were made available. In addition to consulting these during a year of field work, Mrs. Virtue devoted another year to analyzing, writing, and revising the findings to obtain a manuscript satisfactory to herself as author, and to the supervising editor, the faculty, and the editor of the Michigan Legal Series.

The result is this study and analysis of the conduct of 
judicial business in one of the largest metropolitan districts. It should be a contribution to the solution of one of the most acute problems of democracy. It is hoped that the survey may furnish a measuring stick by which those interested in other cities may gauge their local situations, and that it may be useful as a guide to all who wish to make constructive efforts to improve their local conditions.

Since the purpose of the study was simply to recognize and define the special problems of courts in a typical metropolitan area, this volume properly confines itself to facts and conditions without critical comment or specific recommendation. However, comment by this writer, the administrative judge of such a large metropolitan court, who should profit by this study, may not be out of place.

It appears that court administration in a metropolitan district is a problem distinct from the administration of the courts in the State as a whole. It cannot be solved by including it in any plan for state-wide court integration.

It appears that the practice of creating a court to adjudicate each new set of issues has run amuck. The inflexibility of a court system based on many special purpose statutes results in duplication, overlapping, and confusion among these special courts. Shifts in the load of litigation by reason of changing social and economic conditions overburden one court while leaving another idle. Consideration should be given to returning all of these courts to the court of first instance, which should be developed to cover jurisdiction of all types of cases. Administration of judicial business could then profit by proven principles of administration of other branches of government and of business and industry, by establishing a unified and flexible administration, balanced case load, and-when advisable-the use of a specialist judge rather than the development of many specialized courts. 
As a lawyer, this writer commends this survey to the thoughtful study of every other lawyer who is concerned with the contribution his profession should make to balancing the common good against the rights and dignity of the individual. The lawyer may find that while he has been busying himself with stopping the leaks of unauthorized practice here and there, the need for his services in adjusting personal relations has been flowing freely into the cups of the social worker and the administrative assistants of the court.

As one lays down the study, he may wonder that democracy works as well as it does. However, he may console himself with the thought that to recognize shortcomings is the first and most important step; to understand them usually points the solution. It is with that thought in mind that the study is offered to the bench and bar, and also to the layman interested in better government.

IRA W. JAYNE 


\section{Preface}

T T HAS long been recognized that the social problems 1 of the city are something more than a mere multiple of the social problems of the rural community. The bigness of the metropolitan area breeds its own difficulties, which find no counterpart outside its borders. Only recently, however, have experts begun to suggest that this same uniqueness inheres in the problems of the organization of metropolitan courts.

Should the organization of the metropolitan court system differ from court organization elsewhere? How should it differ? Before these questions can be answered, we must know something of existing court organizations in metropolitan areas and of the manner in which they operate. It was for the purpose of securing this necessary background of information that the present study of the Detroit area was undertaken. It proposes to answer this question: What is the judicial organization of the Detroit area, and how does it function?

Late in 1947 , Honorable Ira W. Jayne, chairman of the committee on Judicial Administration in Metropolitan Trial Courts of the Section of Judicial Administration of the American Bar Association, presented to the University of Michigan Law School a request that the Law School co-operate with the Section in a study of metropolitan courts. In accordance with the usual procedure at the Law School, it is necessary that a member of the faculty agree to become a sponsor for a research project before it can be approved. In this instance Professor Edson R. Sunderland agreed to sponsor a study of metropolitan courts provided a qualified person could be secured to make the survey and prepare the study. It was then determined that, 
if such a person could be secured, the factual study of metropolitan court organization would be conducted in the Detroit area. In January, 1948, Mrs. Maxine Virtue, a member of the state bars of Michigan and Kansas, was employed for this purpose on the staff of the University of Michigan Law School as a research associate; and the study was at once undertaken.

Statutory and case materials having a bearing on the subject were first examined. This included home rule and other charters of special character of all municipalities in the area. The main portion of the work, however, consisted in courtroom observation, in interviewing court clerks, judges, probation officers, and other personnel, and in reading litigation files, case histories, and other material. Considerable statistical material was also gathered from court sheets and annual reports. Actual court observation was largely limited to the Circuit Court, Probate Court, Juvenile Court, Court of Common Pleas, Recorder's Court, and Traffic Court. Letters were addressed to each of the justice courts, home rule courts, and other city courts which are found in the Detroit area outside of the city of Detroit requesting data as to their respective court organizations and their operation. Statistical materials were supplemented by the reports of the Judicial Council of Michigan.

Unless otherwise indicated, statistics in this study are for the year 1948. Every effort has been made to insure their accuracy. The year 1949 was spent in preparing and revising the manuscript and in rechecking factual data. Representative officers of each of the Detroit courts studied were given an opportunity to examine the manuscript either in typewritten form or in galley proof, in order that any error of fact might be corrected.

Any introductory statement which I might make would be incomplete if I did not point out that this study would 
have been impossible without the untiring efforts of three persons who co-operated in it. First of all, of course, is Mrs. Maxine Virtue, the author of the study. Her work as an original presentation of an aspect of judicial administration, and as a detailed picture of "law in action," speaks for itself in the pages which follow. Professor Edson R. Sunderland, of the Law Faculty, veteran expert on judicial procedure, was more than a sponsor. He continued to supervise the organization of the materials and to edit the manuscript throughout the process of writing and revising the monograph. The other person whose co-operation was essential to the success of the project was Judge Ira W. Jayne. As representative of the Section of Judicial Administration of the American Bar Association, he was in constant touch with the progress of the factual study. His counsel and assistance in connection with the field work in the Detroit courts was invaluable.

Grateful acknowledgment should be made, both on behalf of the author, Mrs. Virtue, and on behalf of the University of Michigan Law School, for the co-operation of judges, clerks, probation officers, and other court personnel, as well as case workers from public and private social agencies, in affording ready access to records, files, and statistics under their supervision, and in aiding the author of this study in innumerable ways to secure accurate information.

LEWIS M. SIMES,

Director of Legal Research The University of Michigan 


\section{Resolution of the Section of Judicial Administration}

$\Lambda \mathrm{T}$ ITS regular midyear meeting in Chicago, Illinois, Saturday, February 25, 1950, the Council of the Section of Judicial Administration of the American Bar Association adopted the following resolution:

Resolved: That the Study of the Courts of the Metropolitan Area of Detroit, undertaken at the instance of this Section and soon to be published by the University of Michigan, should carry the endorsement of this Section and be published under the joint auspices of this Section and the University;

That the Council expresses its gratitude for the outstanding contribution to the field of judicial administration which this Study constitutes, particularly to Judge Ira W. Jayne for his foresight and leadership in the conception, planning, execution and publication of the Study, and to the University of Michigan Law School for financing and sponsoring it and providing the necessary personnel.

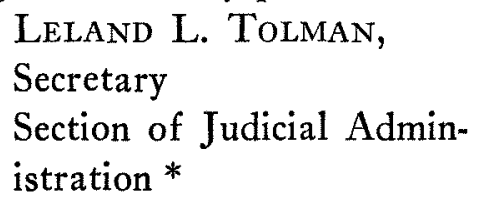

- Section Committee on Judicial Administration in Metropolitan Trial Courts.

1947-1948: Chairman, Ira W. Jayne, Detroit, Michigan

Murray Seasongood, Esq., Cincinnati, Ohio

Judge Richard Hartshorne, Common Pleas Court, Newark, New Jersey

Judge J. Russell McElroy, Presiding Circuit Judge, Birmingham, Alabama

Harry D. Nims, Esq., New York City

J. Ed Lumbard, New York City 
1948-1949: Chairman, Ira W. Jayne, Detroit, Michigan

Murray Seasongood, Esq., Cincinnati, Ohio

Honorable J. Russell McElroy, Presiding Circuit Judge, Birmingham, Alabama

David W. Peck, Esq., Supreme Court, New York City

Judge Emory H. Niles, Baltimore, Maryland

Honorable Edward S. Scheffler, Chief Justice, Municipal Court, Chicago, Illinois

Honorable Robert L. Aronson, Judge of the Circuit Court, St. Louis, Missouri

Honorable Paul A. Buzard, Judge of Division No. 8, Kansas City, Missouri

Honorable Philbrick McCoy, Judge of Municipal Court, Los Angeles, California

Paul G. Kirk, Esq., Superior Court, Boston, Massachusetts

Eustace Cullinan, Jr., Esq., Municipal Court, San Francisco, California

1949-1950: Chairman, Ira W. Jayne, Detroit, Michigan

Murray Seasongood, Esq., Cincinnati, Ohio

Honorable J. Russell McElroy, Presiding Circuit Judge, Birmingham, Alabama

Honorable David W. Peck, Supreme Court, New York City

Honorable Emory H. Niles, Court House, Baltimore, Maryland

Honorable Edward S. Scheffler, Chief Justice, Municipal Court, Chicago, Illinois

Honorable Robert L. Aronson, Judge of Circuit Court, St. Louis, Missouri

Honorable Paul A. Buzard, Judge of Division No. 8, Kansas City, Missouri

Honorable Philbrick McCoy, Judge of Municipal Court, Los Angeles, California

Honorable Paul G. Kirk, Superior Court, Boston, Massachusetts

Honorable Eustace Cullinan, Jr., Municipal Court, San Francisco, California 
Officers of the Section of Judicial Administration of the American Bar Association

1949-1950: Officers

Chairman: John Caskie Collett, Kansas City, Missouri Vice-chairman: James M. Douglas, Supreme Court, Jefferson City, Missouri

Secretary: Leland L. Tolman, U.S. Supreme Court Bldg., Washington, D.C.

Director of State Committees: Paul B. DeWitt, New York City

Section Delegate to House of Delegates: Alfred P. Murrah, U.S. Court of Appeals, Oklahoma City, Oklahoma

1949-1950: Council

The officers ex officio and

Richard Hartshorne, Newark, New Jersey (last retiring chairman)

Armistead M. Dobie, Charlottesville, Virginia

Earl Welch, Oklahoma City, Oklahoma

Earle W. Frost, Kansas City, Missouri

Bolitha J. Laws, Washington, D.C.

John J. Parker, Charlotte, North Carolina

Will Shafroth, Washington, D.C.

Ira W. Jayne, Detroit, Michigan

Arthur T. Vanderbilt, Newark, New Jersey 


\section{Table of Contents}

PAGE

FOREWORD BY IRA W. JAYNE.............. vii

PREFACE BY LEWIS M. SIMES.............. Xi

RESOLUTION OF THE SECTION OF JUDICIAL ADMINIS-

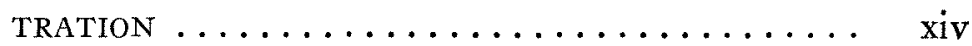

Officers of the Section of Judicial Administration of the American Bar Association......... xvi GUIDE TO TABLES................... xxix

Chapter I. Scope and Purpose of the Survey. .

Section I. In General ................ 3

Section 2. Governmental Units Comprised in the Detroit Metropolitan District.....

Section 3. Characteristics of Metropolitan Districts ................. 8

a. Multiple Governmental Units.......... 8

b. Heavy Case Load............... Io

Large court staffs............... I3

Conditions favoring judicial specialization. . I 4

Use of supplementary administrative agencies for investigation and supervision....... I 5

c. Special Types of Cases.............. I6

Mental cases ................. I6

Traffic cases $\ldots \ldots \ldots \ldots \ldots \ldots \ldots \ldots$ I 8

Criminal offenses ............... 20

Habitual drunkenness .............. 23

Domestic relations cases............. 25

Chapter II. Jurisdiction of Courts in the Detroit Metropolitan District......... 3 
PAGE

Section I. Jurisdiction of the Circuit Court..... 3 I

a. Civil Jurisdiction ............. 3 I

b. Chancery Jurisdiction ........... 33

c. Circuit Court Commissioners.......... 33

d. Criminal Jurisdiction ............. 35

e. Appellate Jurisdiction ............. 35

Section 2. Jurisdiction of the Probate Court.... 36

Section 3. Jurisdiction of the Juvenile Court... 37

a. In General ................ 37

b. Dependent and Neglected Children....... 39

c. Delinquent Children ... . . . . . . . . . 39

d. Children of Divorced Parents......... 40

e. Wayward Minors ............. 40

f. Afflicted and Crippled Children........ 4 I

g. Adoptions ................. 42

h. Juvenile Traffic Offenders........... 42

i. Incidental Jurisdiction over Adults....... 42

Section 4. Jurisdiction of the Recorder's Court of Detroit .............. 44

a. Historical Development ........... 44

b. Criminal Jurisdiction ............ 45

c. Civil Jurisdiction ............. 46

Section 5. Jurisdiction of Traffic and Ordinance Court ............ 46

a. Relation to Recorder's Court.......... 46

b. Traffic Offenses ................ 47

c. Nontraffic Ordinances .............. 47

Section 6. Jurisdiction of the Court of Common

Pleas of Detroit........... 48

a. Creation and Constitutionality........ 48

b. Civil Jurisdiction . . . . . . . . . . 48

c. Criminal Jurisdiction $\ldots \ldots \ldots \ldots \ldots \ldots$ 50 
Section 7. Jurisdiction of Minor Courts in the Metropolitan District Outside De-

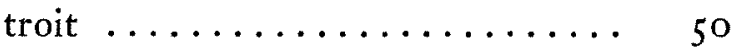

a. Flint Act City Courts.............. 50

b. Home Rule Act City Courts........... $5^{\mathrm{I}}$

c. City Justices Outside Detroit.......... 52

d. Township Justices in the Detroit Metropoli$\tan$ District ................ 53

e. Distribution of Minor Courts in the Detroit Metropolitan District .............

f. Tendency toward Enlargement of Jurisdiction of Minor Courts.............

Chapter III. Organization of Courts in the Detrott Metropolitan District : Judicial Personnel ..................... 56

Section I. Qualifications of Judges......... ${ }_{5}^{6}$

a. Circuit Court ................... $5_{56}^{6}$

b. Probate Court ................... $5_{58}^{8}$

c. Recorder's Court ............... 59

d. Traffic Court ................... 6o

e. Court of Common Pleas of Detroit....... 6I

f. Qualifications of Judges of Minor Courts in the Metropolitan District outside the City of Detroit ................ 62

Section 2. Age of Judges............. $6_{3}$

Section 3. Methods of Selecting Judges........ $6_{3}$

a. Selection of Circuit Court Judges........ 64

b. Selection of Probate Judges........... $6_{4}$

c. Selection of Recorder's Court Judges...... 64

d. Selection of Judges of the Traffic and Ordinance Court .................. 
e. Selection of Judges of the Court of Common Pleas of Detroit................ 65

f. Selection of Judges in Home Rule Cities.... 66

g. Selection of Judges in Flint Act Cities...... 66

h. Selection of City Justices............ 66

i. Selection of Township Justices.......... 66

j. Comment on Methods of Selecting Judges. . 66 Section 4. Compensation of Judges......... 68

a. Compensation of Circuit Judges......... 68

b. Compensation of Probate Court Judges.... 69

c. Compensation of Juvenile Court Judge..... 69

d. Compensation of Recorder's Court Judges. .

e. Compensation of Traffic and Ordinance Court Judges ................... 70

f. Compensation of Common Pleas Judges.... 70

g. Compensation of Judges of Minor Courts in the Area outside the City of Detroit.... $7 \mathrm{I}$

h. Comment on Compensation of Judges..... $7 \mathrm{I}$ Section 5. Organization of Judicial Personnel in Multi-Judge Courts ......... 72

a. Nature of the Problem............. 72

b. Methods Employed in the Several MultiJudge Courts in the Detroit Metropolitan District ................... 74

State-wide organization of circuit judges and recorder's court judges............ 74 Circuit Court of Wayne County......... 75 Probate Court of Wayne County........ 80 Recorder's Court .............. 82

Traffic and Ordinance Court.......... 86

Court of Common Pleas............. 87

Outlying courts in the district......... 90

c. Use of Specialized Judges and Administrative Judges in Detroit.............. 
Section 6. Extent of Judicial Services Rendered. .

a. Hours of Service of Judges........... 93

Circuit Court of Wayne County judges..... 93

Recorder's Court judges............. 94

Common Pleas judges.............. 95

Judges of Traffic and Ordinance Court, Pro-

bate Court, and Juvenile Court....... 96

Comment on hours of service......... 96

b. Case Load per Judge............... 96

Circuit courts ................. 96

Courts sitting in Detroit............ 97

Comment on case load per judge......... $\quad 98$

Section 7. Quasi-Judicial Personnel ......... roo

a. Circuit Court Commissioners........... roo

b. Friend of the Court............. IOI

c. Referees .................... IоI

In the Traffic and Ordinance Court....... IOI

In the Juvenile Court............. ${ }_{102}$

In the Probate Court.............. I0 5

In the Recorder's Court............ Io6

Section 8. Total Personnel Exercising Judicial Functions in Detroit Metropolitan District .............. 106

Chapter IV. Organization of Courts in the Detroit Metropolitan District: AttorNEYS AND JuRIES............... 108 Section r. Attorneys $\ldots \ldots \ldots \ldots \ldots \ldots \ldots$ I08

a. Prosecutor and Defense Counsel in Misdemeanor Cases ................ I08

b. Prosecutor and Defense Counsel in Felony Cases ..................... 108 Assigned defense counsel.......... 109 
Defense counsel in felony cases in Recorder's Court ....................... II I

"Quick justice" ............... I I 2

c. Counsel for Prosecution and Defense in Traffic and Ordinance Court............ I 3

d. Counsel in Probate Court............. II 4

e. Counsel in the Juvenile Court........... I I 5

f. Counsel in the Common Pleas Court....... I I 6

g. Counsel Supplied by Legal Aid Bureau of Detroit .................... II 7

h. Comment on Use of Counsel.......... Ir 7 Section 2. Trial Juries ............ I I 8

a. Right of Jury Trial............... I 8

b. Methods of Selection............... I I9

In general .................... II9

In the Circuit Court of Wayne County as compared with other courts in the state....

By the Circuit Court Commissioners of Wayne County ............... 120

In the Probate Court............. I 20

In the Juvenile Court............. I 2 I

In the Common Pleas Court........... I 2 I

In the Recorder's Court............ I 2 I

In the Traffic and Ordinance Court...... 122

In the city courts outside Detroit......... I 23

Comment on the methods of selecting juries. I 23

c. Extent of Use of Juries in Detroit....... I I23

Use of juries in the Circuit Court........ I 23

Use of juries in felony division, Recorder's Court .................. I 26

Use of juries in misdemeanor division, Recorder's Court .............. I 26

Use of juries in Traffic and Ordinance Court. I 26 
Use of juries in the Probate Court...... I 27

Use of juries in the Juvenile Court. . . . . . 127

Use of juries in the Court of Common Pleas. 127

Use of juries by circuit court commissioners. .

Comment on extent to which juries are employed $\ldots \ldots \ldots \ldots \ldots \ldots \ldots$

Chapter V. Organization of Courts in the DeTroit METROPOLITAN DISTRICT: ADMINIStrative and Clerical Personnel...... I3O Section I. Public Administrators .......... I 30 Section 2. Bailiffs ............... I 3 I Section 3. Clerical Staffs ............. I35

a. In General ................. 135

b. Court Reporters .............. I 36

c. Clerks ................ I 37

In the Circuit Court of Wayne County .... I 37

In the Probate Court of Wayne County... I I 40

In the Juvenile Court of Wayne County.... I 4 I

In the Recorder's Court. . . . . . . . . I 142

In the Traffic and Ordinance Court...... I 45

In the Court of Common Pleas........ I 46

d. Comment on Drafting Journal Entries.... I I 47

e. Periodical Reports ............. I 47

Section 4. Administrative Agencies Performing Administrative and Supervisory Services for Courts........... I 49

a. Probation Agencies ... . . . . . . . . . I 49

In general $\ldots \ldots \ldots \ldots \ldots \ldots \ldots \ldots$ I 49

Probation department of the Circuit Court of Wayne County .............. I 52 Probation department of the Recorder's Court 
Probation department, Juvenile Court of

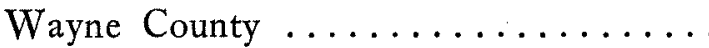

Probation in city and justice courts in Wayne

County outside Detroit............ I 70

Comment on probation............ r $7 \mathrm{r}$

b. Detention Home, Juvenile Court......... I I I

c. Friend of the Court.............. I 73

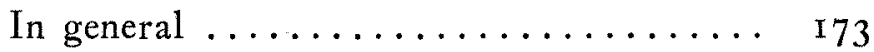

Investigation department ........... I75

Complaint and enforcement department.... 178

Cashier's department ............. I 79

Comment on extent of use of Friend of Court

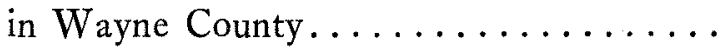

d. Court Agencies Dealing with Mental Problems ..................... I8 r

In the Circuit Court of Wayne County..... I 8 I

In the Recorder's Court............ I 8 I

In the Juvenile Court of Wayne County... I 83

In the mental division of the Probate Court. I 86

Section 5. Size of Court Staffs in Detroit..... 192

Chapter Vi. Machinery for Handling Dockets

and Disposition of Case LoAD........ I94

Section I. Machinery for Handling Dockets at

Circuit Court .............. 194

a. Relation of Pre-Trial Conference to Docket. 194

b. Assignment of Cases.............. 195

Trial calendar ................. 195

No progress calendar.............. 196

Special divisions and dockets.......... I96

Calls ...................... 197

Assignment .................. I9 8 
Section 2. Machinery for Handling Dockets at Recorder's Court ........... I 99

a. Preliminary Examinations ............ 199

b. Misdemeanors ................. 199

c. Felonies .................... 200

Presiding judge $\ldots \ldots \ldots \ldots \ldots \ldots \ldots .200$

Necessary steps preliminary to official docketing ...................... 200

Assembling of docket by docket clerk..... $20 \mathrm{r}$

Daily distribution of docket by presiding judge ................... 202

Maneuvering for or away from a particular judge .................... 203

Section 3. Machinery for Handling Dockets at Traffic and Ordinance Court..... 203

Section 4. Machinery for Handling Dockets at Probate Court ............. 204

Section 5. Machinery for Handling Dockets at Juvenile Court ............. 204

Section 6. Machinery for Handling Dockets at Court of Common Pleas........ 205 Section 7. Age of Cases................ 205

a. Circuit Court ................. 205

Law and chancery cases............ 205

Criminal cases ................. 206

b. Recorder's Court ................ 207

Jail cases ................... 207

Bail cases .................... 208

Machinery for supervising timely disposition of cases .................. $2 \mathrm{I} 3$

Section 8. Disposition of Case Load......... 214

a. Cases Disposed of without Trial........ 214 
Cases disposed of by police without court action

Cases disposed of by court administrative agencies prior to trial........... 215

b. Cases Disposed of Summarily......... 2 I 5

c. Cases Reported as Tried, in which Legal Safeguards Are Not Fully Used.......... 2 I6

d. Age and Duration of Cases.......... 2 I7

Chapter VII. Operative Relationships Among

VARIOUS CoUrTs and LAW ENFORCEMENT and Welfare Agencies in the City of

Detroit .................

Section r. Overlapping, Defective, and Conflicting Jurisdiction over Subject Matter

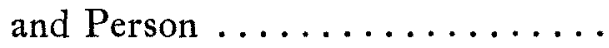

a. Small Claims ................ 2 I9

b. Landlord-Tenant Cases ........... 222

c. Trials de novo on Appeals........... 222

d. Mental Cases ................. 223

e. Chronic Alcoholics ............... 223

f. Criminal Cases .............. 225

g. Cases Involving Minors. . . . . . . . 226

Machinery for waiver of jurisdiction to cure

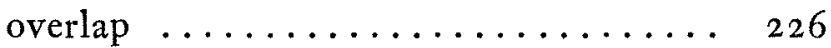

Wayward minors ............. 227

Domestic cases ............... 23 I

Section 2. Extent of Co-operation among Courts. 233

a. Exchange of Personnel, Facilities, Records, and Information ............. 234

Exchange of judicial personnel........ 234

Exchange of other personnel.......... 235

Exchange of facilities ........... 235 
Exchange of records and information..... 236

Transfer and exchange of cases......... 238

b. Areas of Inadequate Co-operation between

Courts .................... 238

"Protected record" at juvenile court...... 238

Family support ............... 24r

Family supervision ............... 244

c. Factors Restricting Co-operation........ 245

Section 3. Effect of Diversity of Sources of Financial Support ............. 246

Section 4. Co-operation between Courts and Welfare Agencies ............. 249

a. Number and Character of Welfare Agencies. 249

Public welfare agencies............. 249

Private agencies ............... 250

b. Areas of Co-operation with Welfare Agencies ..................... 250

Welfare agencies concerned with mental cases ..................... 250

Welfare agencies concerned with criminal offenses $\ldots \ldots \ldots \ldots \ldots \ldots \ldots \ldots .25 \mathrm{r}$

Welfare agencies concerned with child placement .................... 254

Welfare agencies concerned with family case work ................... 256

Welfare agencies concerned with family support ................... 257

c. Methods of Co-operation with Welfare Agencies .................. 258

Probate Court : aid to dependent parents.... 258

Recorder's Court ............... 259

Circuit Court ............... 260

d. Central Registration Bureau.......... 264 
e. Areas and Extent of Overlapping between Courts and Welfare Agencies........ 267

Chapter Viti. Summation and General ConclusIONS ................... 268

APPENDICES

Appendix A. A Chancery Pre-Trial Statement... 273 Appendix B. Organization and Personnel of Courts Operating in Detroit (1948) ....... 275 Appendix C. Hearing on Petition to Commit Alleged Insane Person............. 282 BIBLIOGRAPHY $\ldots \ldots \ldots \ldots \ldots \ldots \ldots \ldots \ldots \ldots \ldots$ $\operatorname{INDEX} \ldots \ldots \ldots \ldots \ldots \ldots \ldots \ldots \ldots \ldots \ldots \ldots \ldots$ 


\section{Guide to Tables}

TABLE

PAGE

I. Courts in the Detroit Metropolitan District..$\ldots \ldots \ldots \ldots \ldots \ldots \ldots \ldots$

II. Illegitimate Births in Detroit and in Wayne

County from 1942 to 1947 Inclusive.... .

III. Consolidation and Civil Jurisdiction of City

Courts in the Detroit Metropolitan Dis-

trict Excluding Detroit.............

IV. Legal Education of Judges of the Circuit

Court of Wayne County (1948).......

V. Judicial Experience of Wayne County Circuit

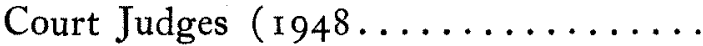

VI. Legal Education of Wayne County Probate and Juvenile Court Judges (1948) .... 58

VII. Judicial Experience of Wayne County Probate and Juvenile Court Judges ( 1948 ) . $\quad 58$

VIII. Legal Education of Recorder's Court Judges (1948) $\ldots \ldots \ldots \ldots \ldots \ldots \ldots$

IX. Judicial Experience of Recorder's Court Judges (1948) ............. 59

X. Legal Education of Traffic Court Judges (1948) .................. 60

XI. Judicial Experience of Traffic Court Judges (1948) $\ldots \ldots \ldots \ldots \ldots \ldots \ldots$ 6o 6

XII. Legal Education of Common Pleas Judges (r 948$) \quad \ldots \ldots \ldots \ldots \ldots \ldots \ldots$.

XIII. Judicial Experience of Common Pleas Judges

(1948) $\ldots \ldots \ldots \ldots \ldots \ldots \ldots \ldots$ 6I

XIV. Age of Detroit Judges.............. $6_{3}$ 
XV. Multi-Judge Courts in the Detroit Metropolitan District (1948)........... 74

XVI. Case Load per Judge, of Courts Sitting in Detroit (1947) ............ 98

XVII. Number and Status of Total Judicial Personnel in the Detroit Metropolitan District (1948) $\ldots \ldots \ldots \ldots \ldots \ldots \ldots \ldots \ldots \ldots \ldots \ldots$ ro6

XVIII. Circuit Court Jury Cases (1947) ...... 124

XIX. Judgments in Jury Trials, Circuit Court of Wayne County (1947).......... I25 XX. Judgments in Nonjury Trials, Circuit Court of Wayne County (1947)......... I25 XXI. Personnel of Courts Operating in Detroit (1948) $\ldots \ldots \ldots \ldots \ldots \ldots \ldots \ldots \ldots \ldots$ 


\section{SURVEY OF METROPOLITAN COURTS \\ DETROIT AREA}




\title{
Chapter I
}

\section{Scope and Purpose of the Survey}

\author{
Section I. In General
}

7 HIS survey was undertaken at the request of the Committee on Judicial Administration in Metropoli$\tan$ Trial Courts, appointed by the Section of Judicial Administration of the American Bar Association.

It is the object of the survey to make a detailed factual study of the organization and operation of the courts of a metropolitan area in order to find a basis for determining in what respects the problems of metropolitan trial courts differ-in substance as well as in extent-from the problems of courts in nonmetropolitan areas. It is thought that when the distinctive metropolitan problems are identified, it will be possible to devise measures for improving the efficiency of judicial administration in metropolitan trial courts.

The metropolitan area of Detroit, which is largely located in Wayne County, Michigan, was selected as the special subject for this study because of its convenient proximity to the Law School of the University of Michigan, at Ann Arbor, which had undertaken to conduct and finance the survey.

Since the statutes, ordinances, and rules regulating the practice of courts cannot give a complete picture of their actual administration, it has been the aim of this survey to supplement fully the study of these regulatory provisions with detailed observations not only of courtroom proceedings and the administrative organization and practices of the courts, but also of the work of a large number of sup- 
plementary agencies. This has required extensive field work throughout the area, including innumerable conferences with judicial and administrative personnel, and the collection of a large amount of statistical data. The generous cooperation of practically all those whose aid and advice were sought in the course of this study is gratefully acknowledged.

It is hoped that by drawing as complete a picture as possible of the organization and operation of the courts of the Detroit area, a pilot survey may be provided which will be useful in making similar studies of other metropolitan areas. A group of such surveys should furnish sufficient comparative data for a sound solution of many of the basic problems of metropolitan courts.

A metropolitan area, in the sense in which the term is used in this survey, is a social and economic unit comprising a large city and the suburbs which cluster around it. The city and its suburbs are usually organized as separate governmental entities.

In 1920, the United States Bureau of the Census took cognizance of the existence of metropolitan areas in analyzing its population reports. In the sense used by the bureau, a metropolitan area is one of 140 areas in the United States, each comprising a district of 100,000 or more inhabitants containing one or more nucleus cities of 50,0oo or more within which conditions of life are predominantly influenced by the central city. Detroit is the center of one of the largest of these areas.

\section{Section 2. Governmental Units Comprised in the Detroit Metropolitan District}

The Detroit metropolitan district, as defined and mapped by the Bureau of the Census, now ${ }^{1}$ includes not only most

1 Bureau of the Census, "Population Characteristics of the Detroit, Mich., Metropolitan District: April, 1947," Current Population Reports, series P-21, no. 19. The map on page 6 is taken from this study. 
of Wayne County, but portions of Oakland and Macomb Counties as well. The area includes twenty-eight cities, ${ }^{2}$ fifteen villages, ${ }^{3}$ and twenty-six townships. ${ }^{4}$

The court problems which can be considered characteristically metropolitan are largely concentrated in Detroit, the central city of the area, and for that reason the administration of justice in Detroit has been treated more exhaustively in this survey than that in the outlying sections of the area. At the same time it has been the purpose to give sufficient consideration to these peripheral courts to show clearly their relation to the central courts in regard to jurisdiction, personnel, and case load.

The number of judicial tribunals in the Detroit metropolitan district as defined by the Bureau of the Census in 1947 is set forth in Table I.

${ }^{2}$ Cities in Wayne County: Dearborn, Detroit, Ecorse, Garden City, Grosse Pointe, Hamtramck, Highland Park, Lincoln Park, Melvindale, Plymouth, River Rouge, Wyandotte (twelve).

Cities in Oakland County: Berkeley, Birmingham, Bloomfield Hills, Clawson, Farmington, Ferndale, Huntington Woods, Oak Park, Pleasant Ridge, Pontiac, Royal Oak, Sylvan Lake (twelve).

Cities in Macomb County: Center Line, East Detroit, Mt. Clemens, Utica (four).

Ecorse, Sylvan Lake, Oak Park, and Clawson, though listed as villages by the census department, are now cities.

3 Villages in Wayne County: Allen Park, Grosse Pointe Farms, Grosse Pointe Park, Grosse Pointe Shores, Grosse Pointe Woods, Inkster, Trenton, Wayne (eight).

Villages in Oakland County: Lake Angelus, Orchard Lake, Rochester (three).

Villages in Macomb County: Fraser, Roseville, St. Clair Shores, Warren (four).

${ }^{4}$ Townships in Wayne County: (listed by tiers) Northville, Plymouth, Livonia, Nankin, Redford, Dearborn, Taylor, Monguagon, Ecorse, Grosse Ile, Gratiot, Grosse Pointe (twelve).

Townships in Macomb County: Sterling, Clinton, Harrison, Warren, Erin (five).

Townships in Oakland County: Waterford, Pontiac, Avon, West Bloomfield, Bloomfield, Troy, Farmington, Southfield, Royal Oak (nine).

The sparsely populated southwestern portion of Wayne County, comprising about one third of the county area, is not included in the Detroit metropolitan district as mapped by the U.S. Census Bureau in 1947.

In 1950, subsequent to the preparation of this book, Livonia Township became the city of Livonia. The I950 census included all of Oakland and Macomb Counties in the Detroit metropolitan district. 


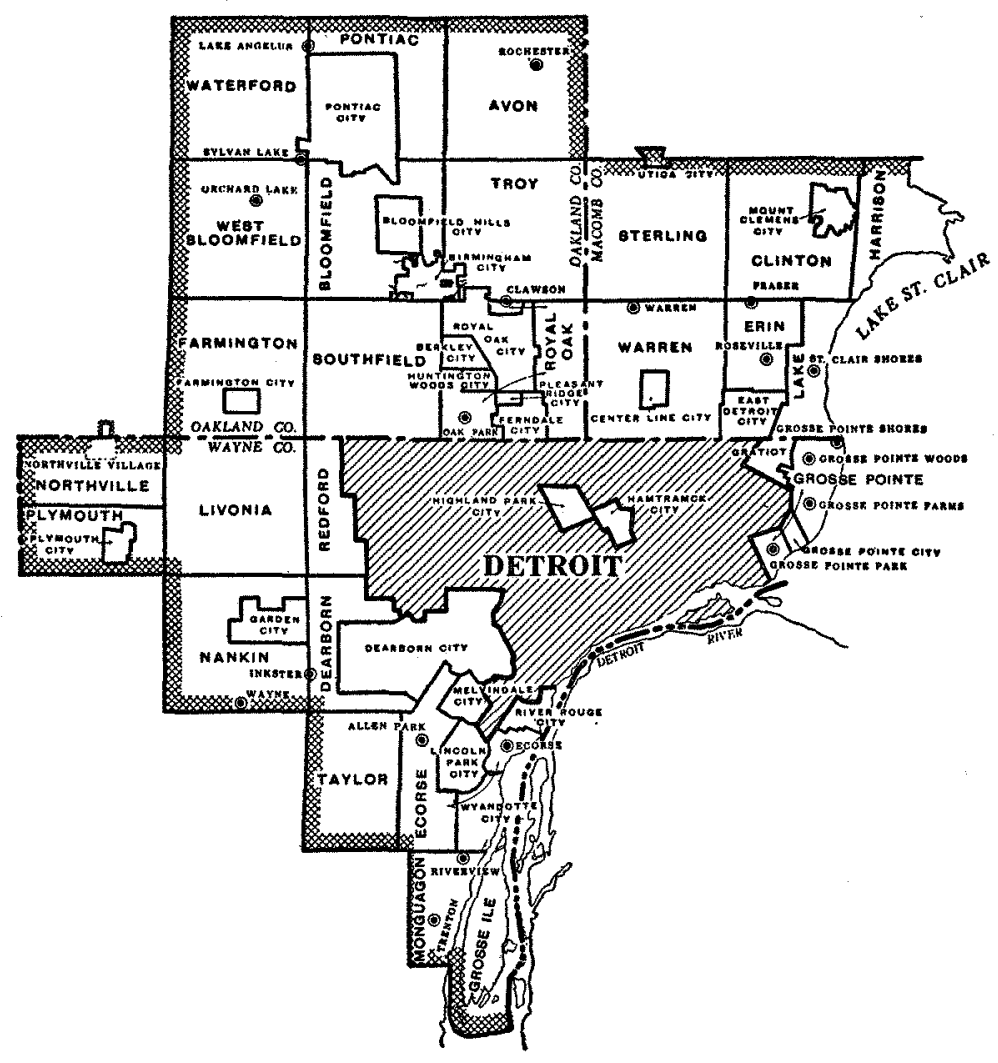

TABLE I

Courts in the Detroit Metropolitan District

Court

Circuit

Probate $\ldots \ldots \ldots \ldots \ldots \ldots \ldots \ldots$ I

Juvenile $\ldots \ldots \ldots \ldots \ldots \ldots \ldots$ r

City of Detroit.................... $3^{1}$

Flint Act city courts.......... $2^{2}$

Home Rule Act city courts...... $4^{2}$

City justice courts.......... $8^{5}$

Township justices $\ldots \ldots \ldots \ldots \ldots 48^{8}$
Wayne Oakland Macomb

County County County Total

Total $\ldots \ldots \ldots \ldots \ldots .68$

\begin{tabular}{ccr} 
I & I & 3 \\
I & I & 3 \\
$\cdots$ & $\cdots$ & 1 \\
$\cdots$ & $\ldots$ & 3 \\
$\ldots$ & $\cdots$ & 2 \\
$6^{3}$ & $1^{4}$ & 11 \\
$6^{6}$ & $4^{7}$ & 18 \\
$36^{9}$ & $20^{10}$ & 104 \\
\hline 50 & - & -
\end{tabular}


1 Court of common pleas, recorder's court, and traffic and ordinance court.

2 The Flint Act is a statute providing for consolidated city courts with jurisdiction up to $\$ I, 500$ in civil matters, and with minor criminal jurisdiction, in cities of more than roo,ooo population. Dearborn and Highland Park, both immediately adjacent to Detroit, have established courts under this act. 73o.xor et seq. Comp. Laws (1948); 27.383 M Mich. Stats. Ann.

The Home Rule Act provides for the optional incorporation of cities and for home rule thereafter. In cities which adopt home rule, the laws governing the jurisdiction of justices of the peace remain in effect unless the cities specifically establish a consolidated home rule city court as permitted by the statute. I17.28 et seq. Comp. Laws (r948); 5.2 ro7 MrсH. Stats. AnN.

In Wayne County, the cities of Lincoln Park, River Rouge, Plymouth, and Wyandotte have home rule courts. Hamtramck, although a home rule city, has retained its two separate justice courts.

${ }^{3}$ In Oakland County, the cities of Birmingham, Bloomfield Hills, Farmington, Oak Park, Pontiac, and Royal Oak are those within the Detroit metropolitan district which have established home rule courts.

4 In Macomb County, there is, among the cities in the Detroit metropolitan district, only one which has a home rule city court: Mt. Clemens.

${ }^{5}$ In the Wayne County portion of the Detroit metropolitan district, the cities of Garden City and Melvindale each have one justice of the peace. The cities of Ecorse, Hamtramck, and Grosse Pointe each have two separate justices of the peace.

${ }^{6}$ In the Oakland County portion of the Detroit metropolitan district, the cities of Berkeley, Clawson, Ferndale, Huntington Woods, Pleasant Ridge and Sylvan Lake each have one justice of the peace. No city in this part of the area has two justices.

${ }^{7}$ In the Macomb County portion of the Detroit metropolitan district, the cities of Center Line and Utica each have one justice of the peace. East Detroit has two separate justices of the peace.

Information as to the status of the courts in cities outside Detroit within the metropolitan district was obtained by consulting the statutes and the charter of each city, and by addressing a questionnaire to the judges and city attorneys, as listed in the 1948 official directory of the county clerk in each county.

${ }^{8}$ The Constitution of the State of Michigan (1908) provides, at article VII, section I5, for a maximum of four justices of the peace in each township. These officers are elected at township elections; one justice may be elected each year. Township justices serve villages within the townships as well as the area that is within the townships but is outside the villages.

In order to learn the number of township justice courts, in the Detroit metropolitan district, the official directory of the county clerk of each county was consulted. Since each justice conducts his own tribunal, the number of justices is also the number of township justice courts.

Each of the twelve townships in the Wayne County portion of the Detroit metropolitan district had four township justices listed in the r 948 directory.

${ }^{9}$ Each of the nine townships in the Oakland County portion of the district lists four justices of the peace in the 1948 directory.

${ }^{10}$ There are five Macomb County townships in the Detroit metropolitan district. The $1948 \mathrm{Macomb}$ County directory, however, does not include justices of the peace among the township officers. As to Macomb County, therefore, the number given is based on the assumption that four justices have been elected for each township, as is the case in the rest of the district. 
Six of these courts are located within the city limits of Detroit; two are in cities-Dearborn and Highland Parkimmediately adjoining the city of Detroit.

\section{Section 3. Characteristics of Metropolitan Districts}

\section{a. Multiple Governmental Units}

The coexistence of many independent and partially overlapping political units is the normal condition of a metropolitan district. The term was adopted by the Bureau of the Census, in fact, because of the wide occurrence of large population centers which had outgrown their original legal boundaries. The haphazard application of traditional local government patterns to the needs of rapidly growing physical communities causes "a mere conglomeration of political divisions of various kinds, established at various times, and not bound together in any way." ${ }_{5}$ A study made by the Bureau of the Census in 1942 showed that the 140 metropolitan districts are made up of a grand total of 15,827 organized governmental units : 272 counties, 895 townships, I,74I municipalities, I I, 822 school districts, and I,097 special districts. The metropolitan district of Detroit at the time of that study was found to contain 458 governmental units : 3 counties, 27 townships, 45 municipalities, 380 school districts, and 3 special districts. ${ }^{6}$

Many of these units, such as the municipalities, have the legal power to develop independent judicial tribunals, which overlap, compete with, and are not integrated with other

5 The Government of Metropolitan Areas in the United States, prepared by Paul Studenski with the assistance of the Committee on Metropolitan Government (New York: National Municipal League, I93o), p. 23. R. D. McKenzie, The Metropolitan Community (New York: McGraw-Hill Book Company, Inc., 1933), p. 303: "The rapid centrifugal movement of urban population and the relatively slow progress of annexation have produced a general dislocation between population and units of local government which is characteristic of all metropolitan areas."

"Bureau of the Census, Governmental Units in the United States r942 (Washington, D. C.: Government Printing Office, 1944), table Ix, p. 64. 
courts in the metropolitan district either in jurisdiction or procedure. Thus, a study of the judicial system of the Chicago metropolitan district in 1932 found $55^{6}$ autonomous courts in the entire region, and 205 in Cook County alone. $^{7}$

Population growth and the independence of various courts within a metropolitan district give rise, then, to a typically metropolitan court problem: there is recurrent shifting and redistribution of court organization and jurisdiction, in response to ephemeral changes in population, in case load, and in the aggressiveness and skill of court personnel. General civil jurisdiction in the Detroit area, for instance, has shifted several times since Michigan was admitted to statehood in I 835. Originally in a circuit court which had jurisdiction beyond the Wayne County line, this jurisdiction was placed in a Wayne County district court in 1843 , but that court was abolished in 1846 , whereupon general civil jurisdiction reverted to the circuit court, in which the circuits had been redistributed so as to constitute Wayne County a separate circuit. Later, in 1873 , the legislature created a special superior court for the city of Detroit, which had jurisdiction over civil cases throughout the city, and which left the circuit court with general superior jurisdiction in that part of Wayne County outside the city limits. But in I 887 , the superior court was abolished, and its functions as a civil court of superior jurisdiction were thereby restored to the Circuit Court of Wayne County. ${ }^{8}$ More re-

7 Albert Lepawsky, The Judicial System of Metropolitan Chicago (Chicago: The University of Chicago Press, r932), p. $4^{x}$.

8 The district court was originally established in 1805 , prior to the statehood of Michigan. The 1843 statute, therefore, was a revival. The historical development of these and other courts in the Detroit metropolitan district is set forth in Michigan Official Directory and Legislative Manual, published by the state of Michigan, 1949-r950, passim; and in Clarence M. and M. Agnes Burton (eds.), History of Wayne County and the City of DeTroit, Michigan (Chicago: The S. J. Clarke Publishing Company, r930), vol. I, p. 568 et seq. 
cently, the court of common pleas, a petty civil tribunal in the city of Detroit, shows a recurrent growth in monetary jurisdiction. This suggests that the court is becoming a general civil court which, within the city limits, will compete with the Circuit Court of Wayne County. ${ }^{9}$ In like manner, the criminal jurisdiction within the city of Detroit has been continually changed by shift and redivision, as is described in another connection elsewhere. ${ }^{10}$ Instability of allocation of jurisdiction, then, is a logical by-product of the multiplicity of governmental units, and of courts especially, in a metropolitan area.

\section{b. Heavy Case Load}

Density of population is the distinguishing characteristic of a metropolitan district. The density is greatest in the central city and decreases toward the periphery of the district. In 1920, the population of the city of Detroit was 996,321 ; in 1930 , it was $1,568,662$. The rate of growth within the city during this decade was only 57.4 per cent; for the area inside the district but outside the city, however, it was I08.9 per cent. The rate of growth for the entire district from I 920 to 1930 was 68 per cent. ${ }^{11}$

From 1930 to 1940 , the population of the entire district increased from 2,104,764 to $2,295,867$-a rate of growth of 9.1 per cent. In a special study of the population characteristics of the Detroit metropolitan district in April, 1947, the United States Bureau of the Census reported that a further increase of 18 per cent had taken place in the population of the entire area since $1940 .^{12}$

Infra pp. 219-221.

10 Infra pp. 3 I-55.

11 Bureau of the Census, Fifteenth Census of The United States: r930: Metropolitan Districts, Population and Area (Washington, D. C.: Government Printing Office, 1932), table 4, p. ro.

12 Bureau of the Census, Sixtenth Census of the United States: r940: Population, Volume I, Number of Inhabitants (Washington, D. C.: Gov- 
In terms of density, the 1930 population per square mile within the city of Detroit was II,375.4; in the area outside the city in the metropolitan district it was 880.8 , and the population per square mile for the entire district was $2,8 \mathrm{I} 9 \cdot 4 \cdot{ }^{13}$ In 1940 , the population per square mile within the city was II,772.7; in the area outside the city limits it was 936.0, and in the entire district, the population per square mile was 2,68I.4. The land area in square miles is given as 746.52 in 1930 and as 856.3 in $1940 .{ }^{14}$

By way of comparison, the 1940 population per square mile of the Chicago metropolitan district was $3,799.3$ ( $16,433.5$ within the city); of Cleveland, 3,6 13.8 ( $12,015.5$ within the city); of Los Angeles, I,885.I $(3,355.5$ within the city); of New York, 4,565.o (23,648.7 within the city); and of Philadelphia, 2,838.2 (15, 833.4 within the city).$^{15}$

The relatively greater density within the city limits accounts for the greater case loads carried by courts located there. These differences are very great. The Court of Common Pleas of Detroit, for instance, which exercises a minor civil jurisdiction within the city, disposed of 40,466 cases in 1947, while the city justice of Garden City, exercising a similar civil jurisdiction in an outlying part of Wayne County, reports ${ }_{1} 76$ such cases during the same period. ${ }^{10}$ The civil case load of the Circuit Court of Wayne County, which has jurisdiction throughout Wayne County in civil cases, was 52.4 per cent of the civil case load of the

ernment Printing Office, I942), table r8, p. 62; and Bureau of the Census, "Population Characteristics of the Detroit, Mich., Metropolitan District: April, 1947," Current Population Reports, series P-21, no. 19, p. r. The population of the city of Detroit as of I940 was 2,104,764, and was 91.6 per cent of the population of the district.

13 Fiftennth Census of the United States, loc. cit.

14 Sixteenth Census of the United States, op. cit., table 77, p. 59.

15 Ibid., table I7, pp. 58-60.

${ }^{16}$ Report of the presiding judge of the Court of Common Pleas of Detroit to the Common Council of the city, 1947. Letter from the justice of Garden City to the writer. 
circuit courts for the entire state of Michigan, ${ }^{17}$ in the year I 947.

The justice at Garden City disposed of twenty-two minor criminal matters in 1947; the Recorder's Court of Detroit in its misdemeanor division disposed of 20,428 misdemeanors during that period, excluding misdemeanors disposed of at traffic and ordinance court. ${ }^{18}$

The circuit courts of Michigan outside Wayne County disposed of $4,4 \mathrm{I} 6$ criminal cases in $1947 .^{19}$ The Circuit Court of Wayne County, which has general criminal jurisdiction outside Detroit, disposed of 500, and the felony division of the Recorder's Court of Detroit disposed of $4,474 \cdot{ }^{20}$ Not only did the 4,974 felony dispositions in Wayne County including Detroit outnumber similar dispositions in the rest of the state by 558 , but the felony dispositions in the city of Detroit alone outnumbered the felony dispositions in the state outside Wayne County by fifty-eight cases. $^{21}$

The size of the case load of the courts in the central city

17 Eighteenth Annual Report of the Judicial Council of Michigan: Judicial Statistics For THE YeAR r947 (September, r948), table II, pp. 31-39, is the source of the figures from which the percentage was computed.

${ }^{18}$ Letter from the justice at Garden City to the writer; ANNUAL REPORT of the Recorder's CoURt of the City of Detroit for the Year 1947.

See infra pp. 46-47 for an explanation of the treatment of the traffic and ordinance division of the recorder's court as a separate court.

19 Erghteenth Annual Report of the Judicial Counchl of Michigan, loc. cit.

20 Ibid., and ANNuAl Report of THE ReCorder's CoURT, supra, n. 18.

${ }^{21}$ I bid. The felony division of the recorder's court has jurisdiction over the same class of cases (classified as felonies and high misdemeanors) as the circuit courts. High misdemeanors are offenses punishable by more than "\$roo fine and/or 90 days' imprisonment," and thus are beyond the jurisdiction of a justice of the peace, but which are not covered by the statutory definition of a felony ("an offense punishable by death or imprisonment in the state prison"): 761.x CoMp. LaWs (1948); 28.843 Mich. Stats. AnN.; and see 750.7 Comp. Laws (1948); 28.197 Mich. Stats. Ann. High misdemeanors are handled like felonies in the circuit courts and in the felony division of the recorder's court. Hereafter, when the word felony is used in this survey, it will be understood to include high misdemeanor unless the contrary is indicated. 
of the metropolitan area distinguish these courts from those outside the central city, and give rise to problems which are encountered only by those persons concerned with judicial administration in such a city. In the Chicago metropolitan district, the same differences between the case load in the central city and the load in outlying portions of the district were found in a I 932 study. In I93 I, it was found, the 193 justice courts in Cook County reported that 80,000 cases were filed during the year, as compared to Io cases filed in the two justice courts in Grundy County. The Municipal Court of Chicago reported 426,756 cases filed, the City Court of Zion, I 8 cases. In the County Court of Cook County 7,794 cases were filed and in the County Court of Kendall County roo were filed. The Circuit and Superior Courts of Cook County reported 46,423 cases filed, as compared with 162 filed in the Circuit Court of Kendall County. In the Cook County Probate Court ro,235 cases were filed and in DuPage County Probate Court 283 were filed. ${ }^{22}$

\section{Large court staffs}

The existence of comparatively large case loads in the central city is reflected directly by the comparatively large court staffs there. The Circuit Court of Wayne County employs approximately 240 persons; the Probate Court of Wayne County, approximately 75 ; the Juvenile Court of Wayne County, approximately i 76 ; the Court of Common Pleas of Detroit approximately 139; the Recorder's Court of Detroit approximately 130 ; and the traffic and ordinance court approximately 150 - there are, at a minimum, 9ro people working for courts in Detroit, and this

\footnotetext{
22 LePawsKY, $o p$. cit., appendix I, table I, at p. 237 , furnished the data from which the figures given were selected.
} 


\section{4 \\ METROPOLITAN COURTS: DETROIT AREA}

figure does not include such occasional personnel as referees and appraisers occasionally appointed in probate court. ${ }^{23}$

Similarly large court staffs have been found in other metropolitan cities: in Cook County, which is approximately equivalent geographically to Chicago, there were 2,257 persons comprising the court staffs there in $1932 . .^{24}$

In the Detroit metropolitan district, large court staffs occur only in the city of Detroit. Even the municipal courts of Dearborn and Highland Park, immediately adjacent to the central city, have total staffs of only nine and ten persons, respectively. The Circuit Court of Macomb County employs eleven persons, that of Oakland County seventeen persons. Most "home rule" courts in the area employ one typist-clerk. In cities with two justices, the justices sometimes co-operate to share the salary of a typist-clerical employee. Township justices ordinarily employ no help, although some of them use, for occasional court work, persons employed by the justices in their private capacities. ${ }^{25}$

\section{Conditions favoring judicial specialization}

The number of judges per court, like the number of all members of court staffs, is larger in metropolitan districts, and is largest in the central cities. In the Detroit metropoli$\tan$ district there are nine multi-judge courts, of which seven are located in Wayne County and five are situated within the city limits of Detroit. There are four courts within the city limits of Detroit which have more than three judges apiece, and such courts occur nowhere else in the district. ${ }^{26}$ There were 146 judges in the Chicago

23 See infra pp. 56-193 for a classification of the duties of these members of the court staffs, especially pp. 192-193.

24 LEPAWSKY, $o p$. cit., table III, at p. ro7.

25 Information furnished by the clerks of the various courts, by the official county directories of Macomb and of Oakland Counties for 1948, and by several individual justices.

26 Table XV, at infra p. 74, presents the multi-judge courts in the Detroit metropolitan district in detail. 
metropolitan district in 1932, of whom 97 were in Cook County alone. ${ }^{27}$ These figures do not include quasi-judicial personnel..$^{28}$

The metropolis especially, and the metropolitan area generally, then, has consistently large case loads handled by multi-judge courts; these two factors seldom occur outside metropolitan areas, and seldom are lacking within them. Such an environment is likely to produce specialized judges, for only in a metropolitan area are there enough cases to justify assignment by subject matter, and only there has the talent of the administrative or presiding judge sufficient scope to mature fully. At a final stage, the specialized docket may develop into a specialized court-e.g., the Juvenile Court in Detroit, the Traffic and Ordinance Court in Detroit, the family courts of Denver and New York, the criminal courts of Cook County, New York, the Parish of Orleans, and many others.

Use of supplementary administrative agencies for investigation and supervision

The tendency to extend the control of courts over individuals for a period of time after trial is apparent in rural, urban, and metropolitan areas-especially in cases involving such social problems as juvenile delinquency, domestic conflict, and criminal offenses, where satisfactory disposition of a single case cannot be obtained by the making of a single court order at the close of the trial. But although a rural or small urban judge may thus extend control, his use of professionally trained psychiatrists, psychologists, case workers, probation officers, and other skilled investigators and supervisors must of necessity be mostly occasional and informal.

27 LEPAWSKY, loc. cit.

28 For quasi-judicial personnel in the Detroit metropolitan district, see pp. 100-107. 
In the metropolis, however, the use of supplementary investigating and supervising agencies as part of the court staffs has reached unique proportions, for two reasons: there are more cases involving social problems in metropolitan districts than elsewhere, ${ }^{29}$ and the size of the court staffs there permits the use of such specialized personnel on a broad scale. The psychiatric clinic at the recorder's court, the probation department in that court with fifty-five probation officers and four separate divisions, and the Wayne County Circuit Court's "Friend of the Court," with almost a hundred employees, could exist only in a metropolis. ${ }^{30}$

\section{c. Special Types of Cases}

The population density in a metropolitan district results in the more frequent occurrence of certain kinds of cases there, and most particularly in the central city, or metropolis.

\section{Mental cases}

Where people are crowded together in numbers of almost I 2,000 per square mile, as in Detroit, the number of mental cases might be expected to be proportionately higher than in less thickly settled places, for several reasons:

(I) Mental deviations show up more quickly and more frequently in the confusion and frictions of a densely populated area. ${ }^{31}$

(2) In the heart of a metropolis, where living quarters

20 See infra pp. 25-30.

30 See infra pp. 149-192.

31 "A shepherd in Wyoming might be as schizophrenic as can be. He wouldn't last five minutes in Times Square." Dr. Riley H. Guthrie, U. S. Public Health Service, quoted in TIME, November 29, 1948, p. 72. Lewis Mumford, The Culture of Cities (New York: Harcourt, Brace and Company, x 938), p. 258, inter alia. Bureau of the Census, Patients in Mental. Institutrons r 934 (Washington, D. C.: Government Printing Office). In this study, which was published as a separate volume, the suggestion was advanced that the conditions under which dwellers in the metropolitan district live tend to contribute to the occurrence of mental deviations. 
are small and scarce, there will be less tolerance of mental deviation, and hence a greater desire to shift responsibility from the family to the court. ${ }^{32}$

(3) The mobility of population in a metropolitan district results in the presence of more people without family connections or friends who are willing to aid them when mental illness occurs. ${ }^{33}$

It has, in fact, been demonstrated that the rate, per unit of population, of admissions to mental hospitals is greater inside metropolitan districts than outside. ${ }^{34}$

The weight of this case load in Wayne County may be indicated by the fact that the Probate Court of Wayne County in the year 1947 dealt with 2,694 persons brought before the court on mental petitions: of this number $2,13 \mathrm{I}$ persons were committed as insane, 349 petitions were dis-

32 In a study of population characteristics of thirty-four selected metropolitan districts in April, 1947, it was found that the proportion of married couples who were sharing the living quarters of others in April, 1947, ranged from about 5 per cent to about 15 per cent. In Detroit, it was ro per cent, or 7o,ooo couples, as compared to $4 x, 200$ in $x 940$. In 1940 , only one of the thirty-four districts had as large a proportion as ro per cent. Bureau of the Census, "Population Characteristics of Metropolitan Districts: April, I 947," Current Population Reports, series P-21, no. 35 ; and "Population Characteristics of the Detroit, Mich., Metropolitan District: April, r947," series $\mathrm{P}-2 \mathrm{r}$, no. $\mathbf{r}$.

${ }^{33}$ Ibid. In April, 1947, $\mathrm{r} 7$ per cent of the population were found to be recent migrants. See also McKenZIe, op. cit., p. 6.

34 Bureau of the Census, Patients in Mental Institutions 1945 (Washington, D. C.: Government Printing Office, 1948), p. 15; Christopher Tietze, Paul Lemkau, and Marcia Cooper, "Personality Disorder and Spatial Mobility," The American Journal of Sociology, July, 1942, pp. 29-39.

See also Howard Woolston, Metropolis: A Study of Urban Communities (New York: D. Appleton-Century Company, Inc, I938) at pp. 82, 83, containing a summary of Dr. H. M. Pollock's study of mental disease in relation to environment, sex, and age. The rates are based on roo,ooo population of the same age in each group, and analyze 63,624 first admissions to hospitals in the United States during r 922. The finding is that for all mental diseases, the rate per 100,000 population is as follows: urban, 89.6 male, 67.8 female; rural, 46.4 male, 35.5 female. Several individual mental diseases are shown at p. 83 , among them alcoholic psychoses (urban male, 8.5, urban female, r.I ; rural male 2.5, rural female o.I). Woolston comments: "These figures leave no doubt. Insanity is more frequently discovered in cities of the United States than in the country." 
missed, IO4 petitions were denied, 53 petitions were discontinued by the petitioners, 57 persons were transferred to the federal Veterans' Administration. ${ }^{35}$ During the first eleven months of 1948 , the mental case load had increased by 5 oo over the 1947 annual total. ${ }^{36}$

\section{Traffic cases}

Population density in the metropolis is expressed daily in traffic congestion, not only because of the number of city dwellers, but also because the size of the city necessitates the use of mechanical transportation several times a day by the average dweller. In addition to this daily movement of dwellers within the city, there are several other factors augmenting the traffic case load in the central city of any metropolitan area.

The commercial and financial leadership of the metropolis is the magnet which attracts the population that causes a metropolitan district to develop. Through the automobile, these large centers have extended their influence upon formerly independent towns, villages, and rural territories, which are thus drawn within the metropolitan district. As one study puts it, the concrete highway has eliminated the distinction between the urban and the rural community, through movement of automobile traffic to and from the central city. ${ }^{87}$

Since many who work in the city live in the suburbs, there is heavy daily suburban commuter traffic, and as the rate of suburban growth increases, this commuter movement also increases. The thickly populated Willow Run

${ }^{35}$ Annual report of the mental division of the Probate Court of Wayne County, (1947).

${ }^{36}$ Information supplied by the head of the mental division, Probate Court of Wayne County.

${ }^{37}$ McKenZre, op. cit., pp. 6-7, 85, et seq. See also chap. XX, beginning p. 296, "Trends in Urban Traffic." 
area, located thirty miles below Detroit in Washtenaw County, and spreading into the southern tip of Wayne County, is not included in the 1947 Detroit metropolitan district. There is heavy daily commuter traffic between Detroit and Willow Run.

In a I930 study of the pattern of motor traffic to and from the city limits of Detroit on five major highways, I 70,000 motor vehicles were counted in twenty-four hours within a four-mile circle, 168,000 within a five-mile circle, I03,400 within a ten-mile circle, 61,200 within a twentymile circle, 40,400 within a thirty-mile circle, 31,400 within a forty-mile circle, and 35 ,ooo within a fifty-mile circle. ${ }^{38}$ And in a seven-hour traffic count made in November, I932, on five major highways leading into Detroit, it was found that passenger-car traffic composed 88.6 per cent of the total. ${ }^{39}$

Since these data were assembled, vehicular traffic in the city of Detroit has increased. The city-wide vehicular traffic index shows a I7 per cent increase between March, 194I, and March, 1949. In the first three months of 1949 , the index is I 5 per cent above a comparable period in I94 I and 7 per cent above the same period in $1948 . .^{40}$

The Traffic and Ordinance Court of Detroit, a consolidated tribunal originating as a specialized division of the recorder's court and having jurisdiction over all traffic matters whether classified as ordinance violations, mis-

${ }^{38}$ Ibid., p. 87. The data were compiled by the Detroit Rapid Transit Commission from traffic counts made by the Michigan State Highway Department and the city of Detroit. "The five trunk-line routes selected were Fort Road-U.S. 25; Michigan Avenue-U.S. Ir2; Grand River AvenueU.S. 16; Woodward Avenue-U.S. ro; and Gratiot Avenue-U.S. 25." See table 40, p. 87 .

39 Ibid., p. 88. " 7 -hour count of traffic made November 26,1932 , under the supervision of Kenneth McGill, University of Michigan, on Detroit highways-count made on U.S. ro, in Royal Oak, on U.S. 25, at Fort Street, and on U.S. 112 in Dearborn. ...."

${ }^{40}$ Letter from Arthur W. Knoske, Safety Engineer, Automobile Club of Michigan, 139 Bagley Avenue, Detroit, April 25, 1949. 
demeanors, or felonies, demonstrates the importance of the traffic case load in Detroit. Detroit police report a total number of 535,555 traffic violations known in 1947 , and the traffic and ordinance court disposed of 543, I5 I traffic cases during the same year. ${ }^{41}$

\section{Criminal offenses}

The density of metropolitan population creates friction, and the degree of mobility peculiar to metropolitan places makes for a substantial degree of anonymity. Another factor, also, contributes to a disproportionately heavy criminal load upon courts in a metropolitan area: namely, the phenomenon of population patterning known as "centrifugal drift." This is the tendency of solid, law-abiding families to move outside the central city, to which the breadwinner commutes for business. ${ }^{42}$ In a study of the residential distribution of over 2,000 of Detroit's substantial families during a twenty-year period, it was found that 50 per cent maintained residence beyond the city limits. ${ }^{43}$

41 Information supplied by the Detroit Police Department and by the chief deputy clerk of the traffic and ordinance court. Offenses known to the police include all offenses of which the police take official cognizance in making their statistical reports.

42 "The most conspicuous form of population shift within the metropolitan area is the so-called suburban ... tendency. This is usually measured in terms of the proportion which the population of the central city or cities bears to the total population of the metropolitan district .... data indicate the tendency of family groups to establish themselves around the periphery of the community." McKenzIE, op. cit., pp. I73-180. See also table 62 at p. 174 and figure 14, p. 18 r.

See supra pp. Io-rI. Between 1920 and 1930 , the total rate of increase in metropolitan areas was: within cities, 19.4 per cent, in areas outside central cities, 39.2 per cent. Fifteenth Census of The United States, op. cit., p. 7 .

43 "The families are those whose names are recorded in Dau's Blue Book and its successor, the Social Secretary, registers of the leading business, professional, and social personages having offices in Detroit." McKenzIE, op. cit., p. 183. See table 65 at p. I84: "Residential Distribution of Detroit's Substantial Families, r9ro-1930" (compiled by Thomas M. Pryor of the University of Michigan): "The general exodus of competent families from the inner zone of the city is apparent." At pp. 184-85: "Whereas in 1910, 
This movement leaves the "weaker and less stable elements of the population" in the metropolis, or central city, wherein remain fewer children, fewer married couples, and more drifting single men. ${ }^{44}$ The concentration of single men is of peculiar import in breeding crime, for the singleman-rooming-house district is accompanied by a concentration of saloons, dance halls, and other places which attract the professional degenerates of the city.

The per capita crime rate is known to increase with the density of population. Specifically, it has been established by several studies that there is more crime per capita in the central city of a metropolitan area than elsewhere, and that the rate of crime, like the rate of destitution, increases toward the heart of the city as the density of population increases. ${ }^{45}$

$5^{\text {I.8 }}$ per cent resided within the Grand Boulevard circle and 9.7 per cent beyond the city's corporate limits; in 1930,50 per cent lived outside the city's municipal boundaries and 7.5 inside Grand Boulevard. . . Measured by almost any index, the city shows a tendency toward increasing wholesomeness and social stability with distance from the center."

44 Ibid., pp. 179 et seq. See especially table 64 at p. 182: "Distribution of Four Series of Social Data in Indianapolis, by Zones," from R. Clyd White, "The Relation of Felonies to Environmental Factors in Indianapolis," JoURNAL OF Social Forces, vol. X, no. 4, May, 1932, 498-509. There zones were established by drawing circles at successively larger numbers of miles from the geographic center of the city. The per cent of single males in zone I (closest to the center) was 35.5 per cent; in zone II, 3 r.o per cent; in zone III, 27.3 per cent; in zone IV, 22.3 per cent; in zone $V, 20.4$ per cent.

See also Sixtennth Census of the United States, op. cit., p. 8.

E. M. Jellinek, "Recent Trends in Alcoholism and in Alcohol Consumption," Quarterly Journal of Studies on Alcohol, vol. 8, no. 1, June, 1947, $\mathbf{1 - 4 2}$; and Robert Straus, "Alcohol and the Homeless Man," QUARTERLY Journal of Studies on Atcohol, vol. 7 , no. 3, December, r946, 360-404.

${ }^{45}$ Reginald E. Watts, "The Influence of Population Density on Crime," 26 Journal of The American Statistical Association, XXVI, March, r93 I, 18; and also Stuart Lottier, "Regions of Criminal Mobility", Journat oF Criminal Law and Criminology, vol. 28, no. 5, 657-673; "Distribution of Criminal Offenses in Metropolitan Regions," ibid., vol. 29, no. 1, 37-50, especially table I, p. 42 and tables, pp. $43-48$; and "Distribution of Criminal Offenses in Sectional Regions," ibid., vol. 29, no. 3, 329-344. The Lottier studies were done in the city of Detroit.

See also McKenzIE, op. cit., table 66 , at p. 185 , showing jurenile delinquency rates by zones from center of city outward in Chicago, Philadelphia, Cleveland, Richmond, Birmingham, Denver, and Seattle. And ibid, at 
The first, eighth, and thirteenth precincts of the Detroit Police Department are closest to the geographic center of the city, and are the most densely populated. The first and thirteenth precincts are described by the police as predominantly slum areas, more than half of the inhabitants of which are "floaters." Single men, nonwhites, and structures other than family dwellings dominate in these two precincts. The eighth precinct is less distressed economically, has more family dwellings, and has fewer different races. The I947 report of the Detroit Police Department contains the following classification: "persons charged, resulting in prosecution by the precinct of arresting officer." Of a total of 29,0 5 offenders so classified, 4,495 were charged from the first precinct, 5,446 from the thirteenth. No other precinct shows more than 2,85 I charges; the eighth precinct accounts for only 623 . These three precincts together account for $3^{6}$ per cent of all offenders charged resulting in prosecution. Precincts one and thirteen together account for 34.2 per cent of such offenders. ${ }^{46}$

The 39,38 I criminal offenses reported as known to the Detroit police in 1947-that is, offenses on which tickets were made out-constitute an increase of 26.3 per cent over 1943. Of the known offenders 28,756 , or 73 .o per cent, are reported by the police to have received final court disposition in $1947 .^{47}$

table 67 , page 186 , are set forth the results of a study of "Felons and Felonies per 1,000 Males 15 to 74 Years of Age and Per Square Mile of Area, by Zones" in Indianapolis, and showing that the rates of both felons and felonies decline rapidly with distance from the business center of the central city.

Rates of destitution: table 64 , at p. 182, cited at n. 44 supra. At zone I, 30.0 per cent of families were on welfare; zone II, 17.9 per cent; zone III, I2.8 per cent; zone IV, 6.5 per cent; zone V, 3.2 per cent.

46 Detroit Police Department, Eightx-Second Annual Report (Detroit, Michigan: 1947), table X, pp. 98-99; and information supplied by the records bureau of the department, from which percentages were calculated by the writer.

${ }^{47}$ Information supplied by the records bureau of the Detroit Police Department. 
The recorder's court disposed of 4,474 felonies in 1947 , the traffic court disposed of 63 traffic felonies, and the Circuit Court of Wayne County disposed of 500 felonies occurring in Wayne County outside the city limits of Detroit. In 1947 , the recorder's court disposed of 20,428 misdemeanors, while the traffic court disposed of 3,240 state traffic violations below the level of felonies. ${ }^{48}$

In Michigan in $1947,47.3$ per cent of all felony dispositions took place in the Recorder's Court of Detroit, and 50.6 per cent of all felony dispositions in the state took place in Wayne County, either in the recorder's court or in the Circuit Court of Wayne County. ${ }^{49}$

\section{Habitual drunkenness}

Among criminal offenses, alcoholism, or habitual drunkenness, has been the subject of numerous studies which show that chronic alcoholism has a heavier incidence, per unit of population, in metropolitan districts than elsewhere. In a study made in 1940 of chronic alcoholism by population size groups, it was shown that the total rate of chronic alcoholism for places of 100,000 and more inhabitants was more than twice as great as the rate for less densely populated places. ${ }^{50}$ The same results were obtained by using deaths from alcoholism as the basis for study: using incidence per unit of population, it was found that urban rates for deaths from chronic alcoholism increased 32.3 per cent between $193^{\circ}$ and 1940 , while in rural areas such deaths decreased 8.5 per cent in the same decade. ${ }^{51}$

48 Annual Report of the Recorder's Court of Detroit, I947; information supplied by chief deputy clerk, traffic and ordinance court; EIGHTEENTH Annual Report of the Judicial. Council of Mrchigan, op. cit., table II, p. 39 .

49 Per cent calculated from Annual Report of Michigan Department of Corrections: "Cases Disposed of During Year 1947."

50 Jellinek, op. cit., table $\mathrm{r}_{4}$, p. 23.

51 Ibid., p. 23. 


\section{4 \\ METROPOLITAN COURTS: DETROIT AREA}

The rate of chronic alcoholism in Detroit in 1940 was reported to be I,044 per I00,000 population, or a total of I 1,654 chronic alcoholics. ${ }^{52}$ Since I 943 , the rate of alcoholism at all levels of the population is said to be rising sharply, so that the present rates would be much higher than the figures shown.

In 1946 , of 9,002 persons charged with drunkenness resulting in prosecution, 3,5 8 were charged from the first precinct and I,930 from the thirteenth precinct, while 254 were charged from the eighth precinct. Of the persons so charged, 62.2 per cent were from all three of these precincts, which are closest to the geographic center of the city, and 59.4 per cent of such persons were accounted for by the first and thirteenth together. ${ }^{53}$

A total of 8,783 persons were reported to Detroit police as intoxicated and later appeared in court as defendants in cases disposed of on that charge during the year. The figure does not include persons who were not charged, nor those who reached court on other charges (such as assault and battery), nor does it include 13,600 persons arrested for drunkenness who were detained overnight and released without action, and for that reason designated by the police as "golden rule" cases. ${ }^{54}$

Eighty-nine of the 1947 referrals to the psychopathic clinic of the recorder's court were charged with drunkenness. ${ }^{55}$ Of 1,753 misdemeanor cases disposed of in October, I948, by the recorder's court, over 32.4 per cent were charged with drunkenness. ${ }^{56}$

Alcoholics are also a problem to the traffic and ordinance

52 Ibid., at table 19, p. 30 .

53 Eighty-First Annual Report, Detroit Police Department (Detroit, Michigan: 1946), table X, pp. 66-67.

54 Information supplied by the records section of the Detroit Police Department.

${ }^{55}$ Information supplied by the psychopathic clinic of the recorder's court.

${ }^{56}$ Information obtained from the court sheets. 
court, which disposed of $\mathrm{x}, \mathrm{OO} 3$ cases of "drunk driving" in 1947, and to the Probate Court of Wayne County, where, in 1947 , sixty-nine petitions for commitment of chronic alcoholics went to final disposition in the mental division of that court: fifty persons were committed to state mental hospitals, nineteen were not committed. ${ }^{.7}$

\section{Domestic relations cases}

In a previous study of the Detroit area, it was said: "the problem of the family court is primarily a problem of large urban areas, where modern conditions have produced the greatest disruption in family organization and where the difficulties in producing satisfactory adjustment of family problems is [sic] greatest." 58

The special nature of the domestic relations case load in this area was recognized in I9I3, when the legislature established a court of domestic relations in counties having upwards of 250,000 population-i.e., Wayne County. The single judge of this court was to have been a judge of the circuit court of the county, and as such was directed by the statute to hear and determine all divorce and annulment suits and other matters assigned to him by the presiding judge of the circuit court of the county. In addition, the statute provided, the court was to have original jurisdiction to try and determine all actions relating to (I) violations of laws compelling support for wife and minor children by husband and father, forbidding desertion and abandonment, prohibiting contribution to delinquency of children, compelling compulsory education of children, and forbidding

${ }^{57}$ Information supplied by chief deputy clerk, traffic and ordinance court, and by head of the mental division of the Probate Court of Wayne County.

${ }_{58}$ Theodore E. Lapp, Frank E. Cooper, and John P. Dawson, "The Administration of Family Law in Michigan," Seventh Annual RePort of the Judicial Council of Michigan (July, r937), p. 7 r. 
cruelty to children; and (2) actions brought to compel support of illegitimate and bastard children.

After election of a judge, but before disposition of any business, the court was attacked by an information in the nature of a quo warranto going to the constitutionality of the statute. The Supreme Court of Michigan declared the statute to be unconstitutional as local and special legislation, because it deprived the probate court of constitutionally bestowed jurisdiction over delinquent children, and for other reasons. ${ }^{59}$

Since that time and at present, the various domestic conflict problems are handled piecemeal in the various courts in which jurisdiction over specific actions falls-divorces in the Circuit Court of Wayne County, juvenile matters in the Juvenile Court of Wayne County, and various criminal actions in the circuit court, the recorder's court, the traffic court, or one of the outlying courts as the case may be.

Although the proportion of marriageable persons is greater inside than outside cities, ${ }^{80}$ the duration of city marriages is shorter ${ }^{61}$ and the frequency of broken marriages is greater in cities. ${ }^{62}$

Specifically, divorces occur almost twice as often in urban areas. A recent study shows that in both $193^{\circ}$ and $194^{\circ}$ divorced persons made up a larger portion of the population in urban than in rural areas ${ }^{68}$ and that in the ten largest cities in the United States, the 1940 population of those

59 Attorney General v. Lacy, 180 Mich. 329 (1914).

60 Woolston, p. 62.

61 Ibid., table p. 64.

62 Loc. cit.

63 Ernest W. Burgess and Harvey J. Locke, The Family: From InstiTution to Companionship (New York: American Book Company, 1945), p. 633: "Of those, 15 years of age and over, who had the marital status of divorced in 1940 the percentages residing in urban, rural-nonfarm, and rural-farm areas, with the respective percentages of the population 15 years of age and older residing in these three areas were: urban, $72.0,59.3$; ruralnonfarm, 17.8, 19.8, rural-farm 10.2, 20.9. For 1930 the respective per cents 
cities showed a disproportionately heavy incidence of the divorced population ${ }^{64}$ of the states in which the cities were located.

In the Circuit Court of Wayne County, 3,766 divorces were granted in the year $192 \mathrm{I}$,

$\begin{array}{rcccc}4,746 & \text { divorces were granted in } & 1925, \\ 5,943 & \text { " } & \text { " } & \text { " } & 1940, \\ 9,702 & \text { " } & \text { " } & \text { " } & 1945, \\ 13,062 & \text { " } & \text { " } & \text { " } & 1946, \\ 9,816 & \text { " } & \text { " } & & 1947 .^{65}\end{array}$

In 1947, Wayne County issued 29,036 marriage licenses. In that year the number of divorces granted was 33.8 per cent of the number of the marriage licenses. ${ }^{66}$

During $1948,13,728$ petitions for divorce were filed during the calendar year; 9,036 divorces were granted, 37 were refused, 5,583 were disposed of by withdrawal or otherwise. ${ }^{67}$

Although city dwellers have fewer children per unit of population than others, illegitimate births are known to

were: urban 69.9, 59.0; rural-nonfarm, 17.7, r8.8; rural-farm, 12.4, 22.2. Thus for both 1940 and 1930 divorces were not distributed in proportion to the distribution of the population; cities had a decided excess, villages a slight deficit, and farming areas a slight deficit.

"Data on the ten largest cities of the United States give additional evidence on the frequency of divorce in cities." Table 25 shows that in 1940 in Detroit, 31.9 of the state's population resided in Detroit, and 37.2 of the state's divorced population were residents of Detroit. Thus the ratio of per cent divorced to per cent urban in Detroit was 1.r7. For all ten cities, the percentage of the state's divorced population 15 years and older residing in the city was significantly higher than the percentage of the state's entire population of the same age group residing in the city. Table at p. 634 .

${ }^{64}$ See supra n. 63 .

65 Joel D. Hunter (ed.), Survey of Community Services in Wayne CoUnty, Michigan (1948), table 22. This and other material cited from the Hunter survey was obtained by a reading of the typescript prior to publication, by permission of the editor.

${ }^{66}$ Marriage license data at ibid., table 20.

${ }^{67}$ Information supplied by the presiding judge of the Circuit Court of Wayne County. 
constitute a larger percentage of all births registered in cities than in the country as a whole. ${ }^{88}$ There were 50, 100 births in the city of Detroit in $1947 ; 1,665$ illegitimate births occurred in the city during the same year. The ratio, therefore, of illegitimacy to recorded births is 3.3 per cent for that year. ${ }^{69}$

A comparison of illegitimate births for six years both for Wayne County and for the city of Detroit has recently been made, and is reproduced below : ${ }^{70}$

\section{TABLE II}

Illegitimate Births in Detroit and in Wayne County from I 942 TO I 947 INCLUSIVE

$\begin{array}{cccc}\text { Year } & \text { City of Detroit } & \begin{array}{c}\text { Wayne County } \\ \text { Outside Detroit }\end{array} & \text { All Wayne County } \\ \text { I942 } & 992 & \text { I I } 9 & \text { I, I IO } \\ 1943 & \text { I,O49 } & \text { I } 42 & \text { I, I9I } \\ 1944 & \mathrm{I}, \mathrm{I} 68 & 2 \text { I6 } & \text { I,384 } \\ 1945 & \mathrm{I}, 404 & 205 & \mathrm{I}, 609 \\ 1946 & \mathrm{I}, 534 & 257 & \mathrm{I}, 79 \mathrm{I} \\ \mathrm{I} 947 & \mathrm{I}, 665 & 270 & \mathrm{I}, 935\end{array}$

In $1947,5,9$ I 8 boys under seventeen were reported as known to the Detroit police because of circumstances indicating delinquency; this is 13.5 per thousand of population. ${ }^{71}$ In the same year 4,292 children were in care of all Wayne County child-caring institutions and agencies, as compared to 4,152 in 1946 . Classified by reason for referral, they are : I,524 neglect, I, I 22 dependency, I, I36 illegitimate, 505 delinquent, 5 feeble-minded. ${ }^{72}$

The Detroit police report 492 prosecutions and convictions for offenses against family and children in 1946,

68 Woolston, op. cit., pp. $6 \mathrm{I}, 68$.

69 HuNTER, op. cit., tables 14 and 21 .

70 Hunter, $o p$. cit., table 14, p. 35 .

71 Information supplied by Detroit Police Department, relation to population calculated in HUNTER, $o p$. cit., table 28 .

72 Hunter, op. cit., table 32. 
a 7.0 per cent increase over I945. They further report 6r I court dispositions of offenses against family and children, with 80.5 per cent of convictions in that year. ${ }^{73}$ These figures do not include criminal action taken by the circuit court in enforcement of support and custody orders relevant to divorces previously granted, nor do they include service rendered by any of the court staffs previous to the attachment of formal court jurisdiction.

The close connection between defective family relationships and delinquency of both adults and children has been established by a number of studies. ${ }^{74}$ About 60 per cent of juvenile delinquents, according to Burt, suffer primarily from defective family relationships. ${ }^{75}$ The Friend of the Court of the Circuit Court of Wayne County, the probation officers of the Juvenile Court of Wayne County, and the head of the women's division of the probation department at recorder's court regard this estimate as exceedingly conservative.

Of great effect upon the incidence of domestic relations cases as encountered by metropolitan courts is the rate of destitution. Destitution has been found to occur more often in large urban areas, and has even been demonstrated to occur in segregated areas of congestion which also show the high-

73 Eighty-First Annual Report, Detroit Police Department (Detroit, Michigan: (1946), table III-A, pp. 16-17, and table III-C, p. 19.

${ }^{4}$ Sheldon and Eleanor T. Glueck, 5oo Criminal Careers (New York: Alfred A. Knopf, r930), pp. ir6-ri7; Frve Hundred Delinguent Women (New York: Alfred A. Knopf, 1934), pp. 70-73; and One Thousand Juvenile Delinguents: Therr Treatment by Court and Cuinic (Cambridge: Harvard University Press, 1934), p. 75 (footnote 20 collates several studies noting the point) and pp. $80-83$ (summarizing results for the study cited). See also Cyril Burt, The Young Delinguent (Bickley, Kent: University of London Press, Ltd., I945), pp. 93-ror; this study deals with juvenile delinquents known to London juvenile courts over a period of several years.

${ }^{75}$ BURT, op. cit., pp. 93-104, especially p. 95. According to E. O. Lundberg and K. F. Lenroot, "Illegitimacy as a Child-Welfare Problem," U. S. CHLDREN's Bureau Bulletin, no. 75, quoted by Burt at p. 94 ff., misconduct among illegitimate children is nearly twice as common as among those born in wedlock. For the relatively very high incidence of illegitimacy in metropolitan areas, see supra pp. 27-28. 
est incidence of vice, crime, and mobility. ${ }^{76}$ There are many reasons for this, among which the most often mentioned are the economic pressures which force the unsuccessful into slum neighborhoods, the environmental influences tending to result in antisocial behavior of all kinds, and the natural tendency of irresponsible persons to display their irresponsibility at various levels of behavior.

Burt found that over one half the total amount of juvenile delinquency in London occurs in homes that are poor (i.e., supported by intermittent earnings) or very poor (i.e., those of criminals, loafers, or the chronically destitute).$^{77}$ In the Harvard Law School survey of one thousand juvenile delinquents in Boston, the Gluecks found that in "only I 2 I of the families had there been no assistance of one kind or another from social welfare organizations, while in eightyeight per cent of the families several agencies had been active." 78 In their study of five hundred delinquent women in Boston, the same authors found that 76.6 per cent of the families of the 500 "were known professionally to social agencies at one time or another prior to the commitment of their daughters to the Reformatory. At least 697 agencies had contact with these families."

Thus the irresponsible family, as such, is the raw material with which the public welfare agencies spend most of their time and with which the courts operating in any large urban area spend much if not most of their time.

${ }^{76}$ Noel P. Gist and L. A. Halbert, URban Society (New York: Thomas Y. Crowell Company, 1937), p. 448 et seq.

77 Burt, op. cit., pp. 66-70, especially p. 69.

78 Glueck, One Thousand Juvenile Delinquents, pp. 69-70, 81.

79 Glueck, Five Hundred Delinquent Women, p. 67. 


\section{Chapter II}

\section{Jurisdiction of Courts in the Detroit Metropolitan District}

$\mathbf{I}^{\mathrm{N}}$

N MICHIGAN, the circuit court is the court of general original jurisdiction throughout each county in the absence of special statutory restrictions. A probate court in each county has jurisdiction over estates, mental cases, and guardianships; its juvenile division is governed by a statute which purports to give it exclusive jurisdiction over children under seventeen and concurrent jurisdiction over older children. Petty civil and criminal jurisdiction lies in township justices, in city justices, or in municipal courts which have replaced the justices.

In Wayne County, wherein lies the city of Detroit, general criminal jurisdiction in the city has been placed in the recorder's court. The traffic and ordinance court, historically a division of the recorder's court, is now a separate tribunal. In like manner, the Juvenile Court of Wayne County, which is located in Detroit, has become entirely separated from the probate court. Petty civil matters in the city are determined in the court of common pleas, a consolidated tribunal succeeding to the civil jurisdiction of the former Detroit city justices. The general hierarchy of courts in the district is set forth in the chart on page 32 .

\section{Section i. Jurisdiction of the Circuit Court}

a. Civil Jurisdiction

In most matters, the civil jurisdiction of the circuit court to determine legal controversies does not extend below $\$ 100$. In the area between $\$ 100$ and the upper limit of jurisdic- 


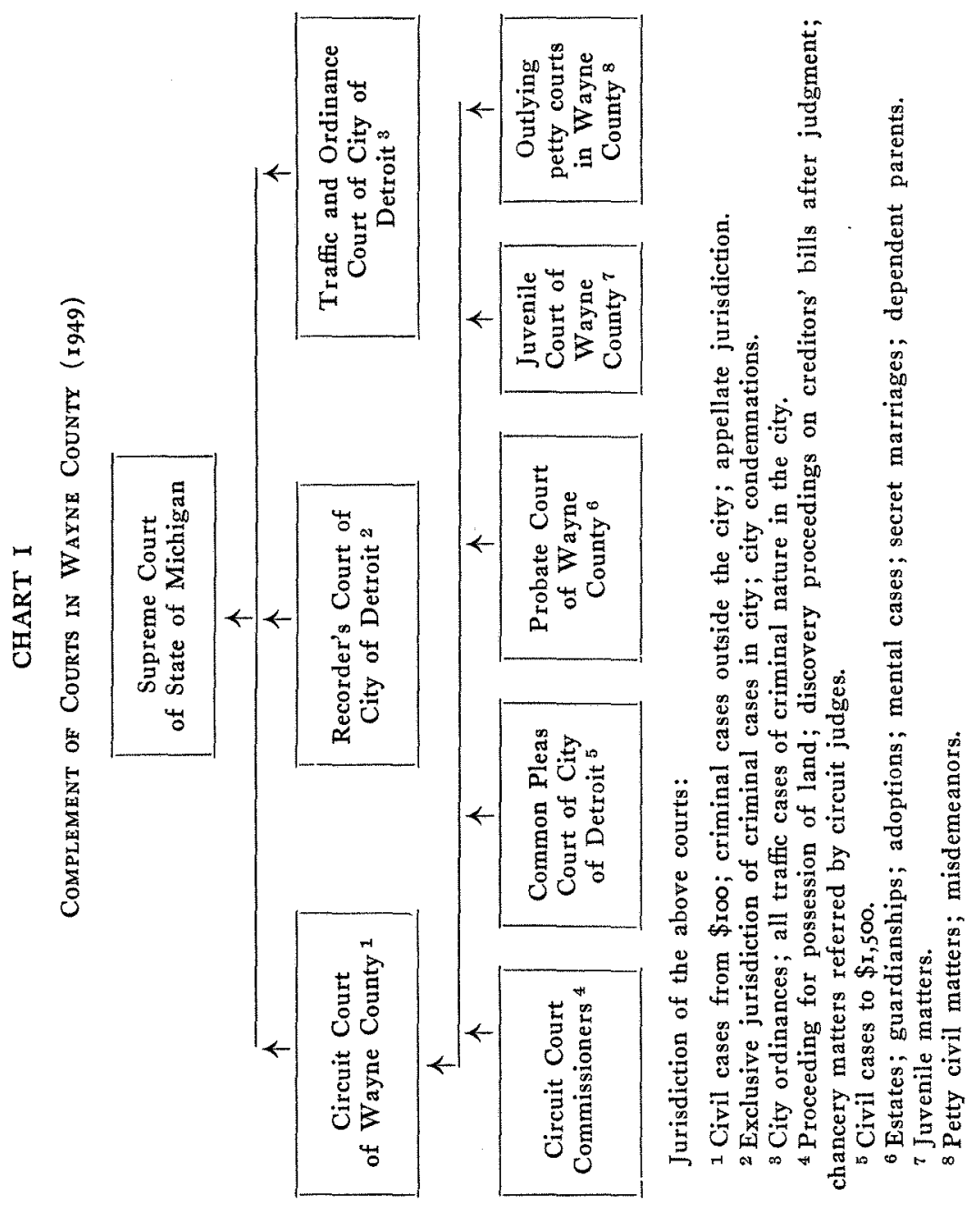


tion of the local justice or municipal court, the jurisdiction of the circuit court is concurrent; above such limit it is exclusive. ${ }^{1}$

\section{b. Chancery Jurisdiction}

When sitting in chancery matters, the circuit court acts as "the circuit court . . . in chancery," and the separation between law and chancery cases is maintained in all court records. A large part of the domestic relations case load in the Detroit metropolitan district falls in the Circuit Court of Wayne County, wherein are heard matters involving marriages of doubtful validity, divorces, and civil acknowledgment proceedings brought by the father of an illegitimate child. ${ }^{3}$ Bastardy proceedings, which are begun in the justice court or its successor as criminal actions, are bound over to the circuit court for the making of a final order for support of the mother and child. ${ }^{4}$ In all these matters, the court exercises a continuing jurisdiction over the minor children, which are its wards, and maintains continuing control over the amount of support, the parties to whom custody is given, and the way in which its orders are carried out.

The chancery jurisdiction is exclusive in the circuit court.

\section{c. Circuit Court Commissioners}

The Michigan constitution prohibits the use of masters in chancery. ${ }^{5}$ Auxiliary judicial officers, however, may perform

${ }^{1}$ Constitution of Michigan (r9o8), art. VII, $\$$ r6: "In civil cases, justices of the peace shall have exclusive jurisdiction to the amount of roo dollars. ..."Jurisdiction is determined by the amount claimed in the declaration, not by the amount recovered. Strong v. Daniels, 3 Mich. 466 (1855), inter alia.

2 606.2-3 Comp. Laws (1948); 27.543-5 Mich. Stats. AnN.

${ }^{3}$ Doubtful marriages: 552.3 Comp. Laws (1948); 25.83 Mrch. Stats. Ann.; divorce: 552.28 et seq. Comp. Laws (1948); 25.106 et seq. Mrch. STATs. ANN.; acknowledgment of paternity: 722.602 CoMp. LAWs (1948); 25.352 Mich. Stats. Ann. (Supp.).

${ }^{4} 722.60$ r Comp. Laws (r948); 25.45 I Mich. Stats. Ann. (Supp.).

5 Constitution of Michigan (Ig08), art. VII, $\S 5$. 
for circuit judges such acts as masters in chancery were wont to do. ${ }^{6}$ The circuit court commissioners, of whom there are one each in Oakland and Macomb Counties, and four in Wayne County, do in fact make reports on certain chancery matters which are referred to them by the circuit judges. Commissioners may not, however, adjudicate children's custody. The chancery jurisdiction is exclusive in the circuit court.

Besides their duties as aides in chancery, the circuit court commissioners have statutory authority to enter final judgments in summary proceedings for the recovery of possession of real estate, after nonpayment of rent, default in the conditions of a land contract, or after sale of mortgaged property. ${ }^{7}$ Commissioners cannot, however, enter a money judgment for rent. Statutory authority is further given the commissioners to compel the attendance of a debtor in discovery proceedings after a judgment on a creditors' bill, and to carry out the discovery proceedings. The litigant in either a land possession or a discovery matter must appeal to the circuit court as from any final judgment. ${ }^{8}$

In Wayne County, the circuit court commissioners make reports to the presiding judge, under whose authority they are placed, with respect to special chancery references. ${ }^{9}$ The Wayne County commissioners, however, have their own filing system and their own clerical personnel, as well as separate courtrooms, and they do not report as to forcible entry and detainer or as to discovery matters,

I Ibid, art. VII, § 21. Michigan court rule 46. Rowe v. Rowe, 28 Mich. 353 ( 1873 ).

7630.13 Comp. LaWs (1948); 27.1987 Mrch. Stats. Ann.; 634.I Comp. Laws (1948); 27.2171 Mich. Stats. AnN.

${ }^{8}$ I bid. In Wayne County, there were 167 such appeals from decisions of the circuit court commissioners in 1948 .

${ }^{9}$ In 1948 , there were fifty-two such special chancery reports, as reported by the presiding judge of the Circuit Court of Wayne County. 
which are handled separately and apart from the business of the Circuit Court of Wayne County. ${ }^{10}$

\section{d. Criminal Jurisdiction}

In general, the criminal jurisdiction of the circuit court embraces felonies and high misdemeanors. ${ }^{11}$ In the city of Detroit, however, the circuit court has no jurisdiction over any criminal offense occurring within the city; its criminal jurisdiction comprises criminal offenses not cognizable by justices of the peace and/or municipal courts, because the offenses were committed outside the city limits of Detroit but within Wayne County.

\section{e. Appellate Jurisdiction}

The appellate jurisdiction of the circuit court extends over all inferior courts and tribunals. ${ }^{12}$ The question of the appellate jurisdiction of the Circuit Court of Wayne County to entertain appeals from misdemeanor convictions in the recorder's court is a perplexing one, which has been more confused by the cases sent up to clarify it. ${ }^{13}$

10 Information supplied by the clerk of the Circuit Court Commissioners of Wayne County, and through observation.

11 Supra chap. I, n. 2x. The line between low and high misdemeanors is drawn by the Detroit police department as follows: "A low misdemeanor is an offense punishable by up to and including \$roo fine and/or 9o days' imprisonment, but less than State Prison. High misdemeanors are those punishable by more than $\$ 100$ fine and/or 90 days' imprisonment."

12 Constitution of Michigan (igo8), art. VII, § 10; 678.1 Comp. Laws (1948); 27.348 I Mich. Stats. Ann.; 730.8 CoMp. LaWs (1948); 27.3758 Mich. Stats. Ann.; 728.4 Comp. Laws (1948), 27.3654 Mich. Stats. Ann.; 804.12 Comp. Laws (1948), 27.3178 (598.22) Mich. Stats. AnN.

13 People v. Jackson, 8 Mich. 78 (1886); Swift v. Wayne Circuit Judges, 64 Mich. 479 (1859); Detroit v. Wayne Circuit Judge, 233 Mich. 356 (r925). And see Grosscup v. Wayne Circuit Judge, 233 Mich. 362 (1925). L. 1883, act 326 provides that recorder's court proceedings may be removed directly to the Supreme Court. L. I919, act 369 , provides that those convicted of misdemeanor without a jury trial may have a rehearing before a different judge of the recorder's court within fifteen days-with a jury. In practice, no appeals are taken from recorder's or traffic court to circuit court. 


\section{Section 2. Jurisdiction of the Probate Court}

In addition to supervisory and dispositive power over decedents' and disappeared persons' estates, the probate court has similar powers over the estates of the mentally diseased, of habitual drunkards and drug addicts, and of minors. ${ }^{14}$ It may exercise continuing guardianship over the persons of minors, mentally diseased persons including those afflicted with epilepsy and feeble-mindedness, and habitual drunkards and drug addicts. ${ }^{15}$

The probate court has authority to commit to institutions for the mentally ill those found to be insane, feeble-minded, epileptic, habitual drunkards, and drug addicts. It also has authority to make orders containing declarations of sanity so as to restore to the cured patient his personal and legal rights. ${ }^{16}$

When an illegitimate child has been conceived, the probate court may perform a secret marriage to protect the mother and to prevent the stigma of illegitimacy from attaching to the child. ${ }^{17}$ A related power over domestic problems is that of the probate court to accept and record affidavits of acknowledgment of parentage of illegitimate children. This proceeding, which establishes the father's duty to support, is widely used in Wayne County. The court

14 Constitution of Michigan (I908), art. VII, § 13, disappeared persons: 705.3 Comp. Laws (1948), 27.3178 (323) Mich. Stats. Ann.; mentally afflicted: 330.11 et seq. Comp. Laws (1948), 44.801 et seq. Mrch. Stats. Ann.; profligates: 703.r CoMp. Laws (r948), 27.3178 (201) Mich. Stats. AnN.; minors: 720.219 CoMp. Laws (1948), 27.3178 (r9) Mrch. STATs. ANn.; habitual drunkards and drug addicts: 703.I CoMp. LAws (1948), 27.3178 (20I) Mich. Stats. ANN.

15 Ibid.

${ }^{16} 330.21$ Comp. Laws (1948); 14.811 Mrch. Stats. Ann.; 330.39 Comp. LaWs (1948), r4.829 Mrch. Stats. ANn.; 720.219 Comp. Laws (1948), 27.31 78 (201) Mich. Stats. Ann.; 330.I8 Comp. Laws (1948), I4.808 Mich. Stats. ANN. The last cited section empowers the court to commit habitual drunkards and drug addicts to institutions for the insane.

17 55r.201 Comp. Laws (r948); 25.5 I Mrch. Stats. Ann. (Supp.). A marriage license is issued without publicity upon showing "deemed to be sufficient by the judge of probate." The statute also permits the marriage, with consent of parents, of persons under marriageable age when, "according to his judgment, such marriage would be a benefit to public morals." 
has power to waive the requirement that the mother join in the acknowledgment, where such waiver is judically deemed desirable. ${ }^{18}$

The probate court may make an order requiring the spouse, parents, children, or grandparents of any poor person to support him. ${ }^{19}$ Petitions for support in such cases are filed by the county prosecutor upon information received from the county welfare authorities. ${ }^{20}$

\section{Section 3. Jurisdiction of the Juvenile Court}

a. In General

Under the Michigan constitution, the probate court has jurisdiction in all cases of juvenile delinquents and dependents. ${ }^{21}$ The present statute provides that when dealing with juveniles under the chapter devoted to that subject, the probate court shall be termed the juvenile division. ${ }^{22}$

In Wayne County, the work of the juvenile division has been handled since $\mathrm{r} 933$ by the same judge, with a separate administrative and clerical staff, in a building some distance away from the County Building where the probate court sits. In operation, the juvenile court is an entirely distinct tribunal having no connection with the probate court except that one of the probate judges spends a day and a half a week at juvenile court on juvenile traffic cases. Because of this separate identity and jurisdiction, the juvenile court is treated, for the purpose of this survey, as a separate court.

In this connection, it is interesting to note that a 1905 statute establishing a separate juvenile court was held unconstitutional. ${ }^{23}$

18 702.83 Comp. Laws (1948); 27.3178 (r53) Mrch. Stats. Ann. (Supp.). ${ }^{19} 400.77$ and 401.2 Comp. Laws (1948); 16.122 and 16.477 Mrch. Stats. AnN. (Supp.).

${ }^{20}$ See infra pp. 258-259.

21 Constitution of Michigan (Igo8), art. VII, § 13.

22 712.A.1-712.A.28 CoMp. LAWs (1948); 27.3178 (598.1)-27.3178 (598.28) Mich. Stats. Ann. (Supp.).

23 P.A. no. 312, r905, established juvenile courts in all but seven counties, 
Until I944, the juvenile statute defined various classes of children coming within the jurisdiction of the juvenile court -e.g., ". . . the words 'delinquent child' shall include any boy or girl under I 7 . . who violates any law. . . ." This portion of the statute was called "the branding law" by members of the juvenile court staff and by case workers working with children, because it officially designated the delinquent child a criminal offender. Accordingly, the law was overhauled in 1944 for the purpose of eliminating "branding," and the present statute specifically states that its proceedings are not criminal in nature. ${ }^{24}$ The definitions have been eliminated from the present statute: although the circumstances giving rise to jurisdiction in the various classes of cases are specifically stated, no child is labeled "delinquent," "dependent and neglected," or "wayward minor."

In practice, however, "to facilitate everyday working procedure," the court staff still uses these terms, and a child coming within the jurisdiction of the court is dealt with by the particular department organized to handle that type of case. The writer also noted that the Detroit Police Department and the recorder's court still include, on the case history of each person with a previous record, a list of

to be presided over by circuit judges, by circuit court commissioners, or by circuit judges, according to the population of the various counties. In Wayne County, the circuit judges were to name, by majority vote, one or more of their number to hear cases concerning dependent, neglected and delinquent children. Records were to be separate.

In Hunt v. Wayne Circuit Judges, I42 Mich. 93 (Ig05), the court said that since the plan conferred on circuit court commissioners powers beyond their constitutional jurisdiction, and hence rendered the statute nugatory in most counties, the entire plan must fail.

24 "Proceedings under this chapter shall not be deemed to be criminal proceedings." 712.A.I Comp. LaWs (1948); 27.3178 (598.1) Mich. Stats. Ann. (Supp.). There is nothing new about the renunciation of criminality in juvenile courts; it underlies the entire development of juvenile court law. See Stermer and Rosemont, Manual for Juvenile Court Officers of the State of Michigan at pp. 24, 73. Legal consequences are far-reaching: sentence can be suspended indefinitely (People v. Brown, 54 Mich. 15 (1884)); detention is not commitment (People v. Felker, 6r Mich. xro (x886)). 
delinquency contacts with the juvenile court. ${ }^{25}$ The practical conclusion appears, therefore, to be that despite the amendment of the statute, the child is still "branded" for all legal purposes.

\section{b. Dependent and Neglected Children}

The class of children described by the constitutional provision as "dependent" are referred to as "neglected" in the juvenile court. The statute confers original exclusive jurisdiction over any child under seventeen whose "parent or other person legally responsible ... when able to do so, neglects or refuses to provide proper . . . support, education ... or other care ... or who is abandoned ... or who is otherwise without proper custody or guardianship. . .." ${ }^{\prime 26}$ The juvenile court maintains a dependent and neglect department to "protect and supervise" such children by "removing them from the custody of their parents and placing them in boarding homes through private childcaring agencies at county expense, where they will receive proper care and supervision." ${ }^{27}$ Closely related is the statutory jurisdiction over children whose homes are unfit, or whose unmarried mother is without means, or who frequent places where liquor is sold. ${ }^{28}$

\section{c. Delinquent Children}

The juvenile court has exclusive original jurisdiction over any child under seventeen who has violated any "municipal

${ }^{25}$ For instance, on April 18, 1948, a random check of the last 500 felony cases investigated by the probation department at recorder's court showed 127 with juvenile court delinquency contacts.

${ }^{26} 7$ I2 A.2 Comp. Laws (I948); 27.3178 (598.2) Mich. Stats. Ann. (Supp.). 27 "The Wayne County Juvenile Court, Detroit, Michigan," a descriptive mimeographed article of six pages supplied by the juvenile court staff. The material is not dated. This quotation is from page 2.

28 Supra n. 26. 
ordinance or law of the state or of the United States," who has deserted his home, who has immoral associates, who absents himself from school, who is disobedient or an idler, or who repeatedly patronizes a place where liquor is sold. ${ }^{2 \theta}$ And it is elsewhere provided that where a child under seventeen is charged with crime in any other court, that court shall transfer the case to the juvenile court and the child to the place of detention designated by the juvenile court. ${ }^{30}$ Where a child over fifteen is accused of a felony, the judge may waive jurisdiction to the court of general criminal jurisdiction, but it is specifically provided that such waiver must follow motion of the prosecuting attorney and investigation and examination including notice to the child's parents. In the absence of such waiver, the court of general criminal jurisdiction has no power to try the case. $^{31}$

\section{d. Children of Divorced Parents}

The juvenile statute also contains a provision giving the juvenile court exclusive jurisdiction over children under nineteen over whom the circuit court has waived jurisdiction incident to custody arising in connection with an action in divorce. Such children might, of course, be neglected, delinquent, or might be wayward minors. ${ }^{32}$

\section{e. Wayward Minors}

The juvenile court has jurisdiction concurrent with that of the court of general criminal jurisdiction over children between seventeen and nineteen found within the county who are addicted to the use of drugs or alcohol, who

${ }^{29}$ Ibid., at subsection (a) (8).

${ }^{30} 712$ A.3 Comp. Laws (1948); 27.3178 (598.3) Mich. Stats. Ann. (Supp.).

31712 A.4 Comp. Laws (1948); 27.3178 (598.4) Mich. Stats. Ann. (Supp.).

327 r2 A.2 Comp. Laws (1948); 27.3178 (598.2) Mich. Stats. Ann. (Supp.), at subsection (b). 
repeatedly associate with dissolute persons, who are found of their own free will in a house of ill fame, who are wilfully disobedient, or who habitually idle away their time. ${ }^{33}$ The machinery is designed to permit the reference by the prosecuting attorney of children who could be tried in a criminal court, but who "can be saved from a possible criminal record and jail sentence" by the jurisdiction of the juvenile court. ${ }^{34}$

This legislation, the juvenile court staff advises, was enacted in response to the unique problem existing in Wayne County, where there are large numbers of mischievous and incorrigible late adolescents who should be dealt with by a court, but who should be preserved from prolonged contact with the crowds of professional criminals and degenerates comprising the bulk of the criminal case load in Detroit.

\section{f. Afflicted and Crippled Children}

The probate court's authority to receive and investigate applications for medical and hospital care for afflicted children, and to approve or reject such applications when completed, has been transferred by the probate court to the juvenile court. A pregnant child is "afflicted" for purposes of this statute. ${ }^{35}$ In like manner, the probate court's jurisdiction to make orders for the hospitalization of crippled children, after investigation by the proper state commission, is carried out by the juvenile court. ${ }^{36}$ In dealing with both afflicted and crippled children, the court deter-

33 7r2 A.2 Comp. Laws (1948), 27.3 r78 (598.2) Mich. Stats. Ann. (Supp.), at subsection (b).

34 "The Wayne County Juvenile Court, Detroit, Michigan," op. cit., at p. 3 . 35 722.301-3 I9 CoMp. Laws (1948), 25.422 (I)-25.422 (26) Mich. Stats. AnN. (Supp.).

${ }^{36} 722.201-240$ CoMp. LaWs (r948), 25.445 ( 1 )-25.445 (44) MICh. Stats. Ann. (Supp.). 
mines the existence of jurisdiction on the basis of the county where the child is found, rather than that where it resides. ${ }^{37}$

\section{g. Adoptions}

Jurisdiction over adoptions, which under the Michigan statute applies only to minors, is placed in the probate court. In practice, the application is filed, the investigation carried out, and the order drafted in the juvenile court, and the entire file is then sent to the probate court for the signature of a probate judge. Under this practice, each of the two courts must handle and keep some record of all adoption matters. ${ }^{38}$

\section{h. Juvenile Traffic Offenders}

Persons under seventeen who are arrested for traffic violations are referred to the juvenile court for hearing and disposition. $^{39}$

\section{i. Incidental Jurisdiction over Adults}

Where necessary for carrying out an order affecting a child, the juvenile court is given statutory authority to make orders affecting adults. ${ }^{40}$ It also has power to punish for

27 Op. Atty. Gen., July 28, 1942, no. 22642; idem, December 8, 1939 (number not known); idem, June 25,1943 , no. 90844 .

${ }^{38}$ Information supplied by register of probate court and register of juvenile court. During field work, both registers stated that adoption orders, though drafted at juvenile court, were transmitted to probate court before the orders were signed. The register from juvenile court, after reading this text in galley proof, comments as of June 16 , 1950: "As a matter of fact the entire adoption is completed here at Juvenile, signed by our Judge and then sent to Probate for filing only. There is no duplication of records under this system."

39 Information supplied by chief deputy clerk, traffic court and by register, juvenile court.

${ }^{40} 7$ I2 A.6 Comp. Laws. (1948); 27.3178 (598.6) Mich. Stats. Ann. (Supp.). 
contempt. ${ }^{41}$ In practice, in Wayne County, no effort is made to exercise direct jurisdiction over adults except by collecting from parents money expended by the court to care for children under the court's jurisdiction.

* * * $*$

In general, the exercise of jurisdiction by the juvenile court is broadened by several statutory factors, all going to the necessity of long-term supervisory care by the court. For instance, any child may be detained on authority of the juvenile court by any police officer, sheriff or deputy sheriff, county agent, or probation officer, if found in circumstances likely to endanger his health, morals, or welfare. Such a child may be detained indefinitely by the juvenile court, since detention by this court does not constitute imprisonment but is in the nature of protection..$^{22}$

Again, the statute authorizes the making of a preliminary inquiry before the filing of an official petition. In practice, a great deal of the court's work is done in this manner; the filing of an official petition is regarded as a last resort. ${ }^{43}$

In order to facilitate informal handling of matters affecting children, it is provided that hearings may be adjourned from time to time and may be conducted in an

41712 A.13 Comp. Laws (1948); 27.3178 (598.13) Mich. Stats. Ann. (Supp.).

${ }_{42} 712$ A.r4 Comp. Laws (1948); 27.3178 (598.14) Mich. Stats. Ann. (Supp.). Supra n. 24.

43 A fuller discussion of the procedures of this court is given in the chapter on court organization hereinafter. In general, the practices here as in any juvenile court are geared to disposition of each case without resort to filing an official petition or making any record which may stigmatize the child in later years. See Jessica Sinclair Kimball, A Manual of Court Function and Procedure for Social Workers, compiled under the auspices of the Council of Social Agencies of Metropolitan Detroit and of Wayne University, in describing the work of the Juvenile Court of Wayne County, at p. Io: "If the problem can be solved unofficially ... the court is eager to assist ... an earnest effort is made to first exhaust all other resources. Mutual cooperation is encouraged with other agencies in the court's unofficial role; the official filing of a petition is a last resort for the child's protection or rehabilitation." 
informal manner, and that no transcript need be made or stenographic notes taken. ${ }^{44}$ So that even where it has been found necessary to have a formal petition drawn and a hearing set down, it is possible for any matter to be handled short of the making of a final order by means of indefinite adjournment. This technique is often used in the Juvenile Court of Wayne County: the judge or referee will issue instructions and adjourn the hearing with the understanding that if the instructions are carried out, no final order need be entered.

A similar device is that of entering an order of a drastic nature-e.g., an order for the deprivation of custody of a neglected child, or for the commitment of a delinquent child to an institution-with the oral announcement to the principals in the action that the order need not be carried out if the parents or child, as the case may be, so govern themselves as to render enforcement of the order unnecessary.

All of these provisions and administrative techniques are designed to enable the juvenile court to adjust the child and its family short of the application of legal force.

Section 4. Jurisdiction of the Recorder's Court of Detroit a. Historical Development

Under the Detroit Charter of I 824 , the recorder of the city was a member of the Common Council of Detroit with certain quasi-judicial powers. In $185^{\circ}$, a specialized justice of the peace was designated to handle all criminal justice assignments within the city of Detroit; this magistrate was known officially as the police justice, unofficially as the "police court."

In 1857 , the Detroit Charter was amended. At that time, ${ }^{44} 7 \mathbf{2} 2$ A.r7 Comp. Laws (1948); 27.3178 (598.17) Mich. Stats. Ann. (Supp.). 
the recorder's court was established, with bipartite jurisdiction:

( I) It succeeded to the jurisdiction of the old mayor's court over ordinance violations;

(2) It was authorized to exercise general original criminal jurisdiction over felonies and high misdemeanors ${ }^{45}$ within the corporate limits of the city of Detroit. This jurisdiction had until 1857 been in the Circuit Court of Wayne County.

The "police court," with petty jurisdiction in criminal matters within the city, coexisted with the recorder's court until r9I9, when the legislature, after a city referendum, abolished the office of police justice and conferred this jurisdiction, also, upon the recorder's court. ${ }^{46}$

\section{b. Criminal Jurisdiction}

The recorder's court has original and exclusive jurisdiction of all prosecutions in behalf of the people of the state for crimes and offenses committed within the corporate limits of the city of Detroit, with the exception of those matters specifically placed within the jurisdiction of the traffic and ordinance division.

Specifically, the court exercises jurisdiction similar to that of city justices in that it tries and determines misdemeanors committed within the city, conducts preliminary examinations for felonies committed within the city, and arraigns defendants charged with felonies committed within the city. The court exercises general criminal jurisdiction in

${ }^{45}$ Supra chap. I, n. $2 \mathrm{x}$.

46 Burton, op. cit., vol. I, p. 575 et seq.; Charles B. O'Hagan, Detroit RECORDER's COURT (Michigan Historical Records Society, 1942), at pp. 1-4, contains a thorough legislative history of the court.

The I9I9 legislation establishing the court, the "Municipal Courts of Record Act," was act 369 of $19 \mathrm{Ig}$. Although this is not a public act, it is compiled as 725.1 et seq. Comp. Laws (1948); 27.394I et seq. Mich. Stats. Ann. 
that it tries and determines felonies committed within the city. ${ }^{47}$

\section{c. Civil Jurisdiction}

The recorder's court has jurisdiction over condemnation proceedings wherein the city of Detroit acquires private property for public use by right of eminent domain..$^{48}$

The recorder's court has statutory jurisdiction to try certain local transitory actions which may be referred to it by the Circuit Court of Wayne County, and for some years did exercise this civil jurisdiction. No cases have been referred, however, since 1944, and at the present time this jurisdiction is not actually being exercised. ${ }^{49}$

\section{Section 5. Jurisdiction of Traffic and Ordinance Court}

\section{a. Relation to Recorder's Court}

In 1929 , the legislature, after city referendum, amended the organization of the recorder's court by establishing the present separate traffic and ordinance division. The division was given entirely separate jurisdiction, personnel, and records, and the judges of each division were specifically prohibited from participating in the organization and operation of the other division. ${ }^{50}$ The traffic and ordinance division is housed in a separate building, and in actual opera-

47 726.1 I CoMp. LAWs (1948); 27.356r Mrch. Stats. Ann. See also 725.ro Comp. Laws (1948); 27.3950 Mrch. Stats. AnN.

48 Charter, City of Detroit, r945, title VIII, chap. I, \$\$ I9, 22.

49725.23 CoMp. Laws (1948); 27.3966 Mich. Stats. AnN.

50 The extent and method of this sharing is discussed hereinafter. The clerk's title is almost entirely formal, with respect to traffic and ordinance court. See 725.19 Comp. Laws (1948); 27.3959 Mich. Stats. Ann., which gives the chief deputy clerk responsibility and authority for the separate administration of the traffic and ordinance court records.

725.18 Comp. LaWs (1948); 27.3958 Mich. Stats. Ann.: "Said judges [of the traffic and ordinance court] shall not participate in the organization and operation of the other division of the municipal court or branches thereof; and shall have no other jurisdiction than that provided herein." 
tion there is no connection between the two courts except that the clerk of the recorder's court is ex officio clerk of the traffic and ordinance division, and there is sharing of jury panels and certain specialized administrative departments. The traffic and ordinance division is hereafter treated in this survey as a separate court.

The constitutionality of the legislation creating the traffic and ordinance court was upheld, the court saying that though mechanically a part of the recorder's court, it is "substantially as much divorced from . . . the recorder's court as though they were separate courts."

\section{b. Traffic Offenses}

The traffic and ordinance court has original and exclusive jurisdiction over all violations of traffic ordinances occurring in the city of Detroit, and over all offenses, whether misdemeanor or felony, arising in the city under motor vehicle and highway traffic laws, as well as over homicides committed within the city in the operation of a motor vehicle. ${ }^{52}$

\section{c. Nontraffic Offenses}

The traffic and ordinance court has jurisdiction over all violations of ordinances of the city of Detroit not having to do with traffic or motor vehicular operation-e.g., violations of garbage disposal, business licensing, and business operation ordinances are among those tried and determined in this court. ${ }^{53}$

51 Attorney General, ex rel. Judges of Recorder's Court v. Judges of Recorder's Court, 250 Mich. 448 (I930), at p. 449: "The statute provides for a sort of court within a court. . . . Much of the language ... would be appropriate to the creation of an independent court. ... But it is equally plain that the legislature intended to retain all the criminal business of the city in one court. ..."

52 725.1 8 Comp. Laws (1948); 27.3958 Mich. Stats. AnN.

${ }^{53}$ Ibid., and see 726.22 Comp. Laws (1948); 27.3572 Mich. Stats. Ann. 


\section{Section 6. Jurisdiction of the Court of Common Pleas of Detroit}

\section{a. Creation and Constitutionality}

In I929, a legislative enactment consolidated the six independently functioning justices of the peace in the city of Detroit into a single nine-judge court. ${ }^{54}$ The validity of the statute was attacked by way of mandamus. In analyzing the effect of the consolidation, the state supreme court said that the statute co-ordinates the work under the direction of a presiding judge, and said also "it must be held that the act continues the justices' courts under another name and does not create a new court."

Commenting on the fact that Detroit is admittedly the only city covered by the act, the court said: "Here, population is of the essence of the condition sought to be corrected. Growth of population causes increase of litigation and requires more judges to handle it. When the litigation becomes burdensome, its proper disposal requires co-operation among the judges. ... It appearing that there is a reasonable relation between population and the object of the law, the act, general in form, must be held to be general within the Constitution."

\section{b. Civil Jurisdiction}

The new court has succeeded to the jurisdiction of the justices of the peace prior to the consolidation. Specific jurisdiction over actions against life insurance companies, co-operatives, and mutual benefit companies up to the monetary maximum of jurisdiction has been affirmatively given the court, because justices had no such jurisdiction. ${ }^{56}$

54 P.A. 260 of 1929. The statute, popularly known as "The Court of Common Pleas Act," is 726.II-726.29 CoMp. Laws (1948); 27.3651-3680 Mich. Stats. Ann. (Supp.).

${ }^{55}$ Kates v. Reading, 254 Mich. 158 (1931), pp. 165-6. Compare supra Chap. I, n. 59 .

56 728.x Comp. Laws (1948); 27.365 I Mich. Stats. Ann. 
The monetary maximum was increased by a 1947 amendment to embrace "all civil actions now cognizable in said circuit court wherein the debt or damages do not exceed $\$ 1,500$ except actions against municipal corporations, and where the value (of property to be attached or replevied) does not exceed $\$ \mathrm{I}, 500 . "{ }_{57}$ The 1947 legislature by further amendment gave the court jurisdiction to try certain actions against certain municipal corporations, thus opening the way to the filing of small claims against the city of Detroit in common pleas court instead of in the Circuit Court of Wayne County, to which latter court such claims had recently become a problem because of their number. ${ }^{58}$

The language of the 1947 amendment quoted above leaves the geographic jurisdiction in doubt. Many attorneys and some of the common pleas judges construe it to remove the limitation of city residence of one or both parties, and a number of county civil cases have been accepted.

The growth of monetary jurisdiction and the tendency towards geographic growth, like the consolidation of previously independent judicial officers, make the development of this court typically metropolitan..$^{59}$

$57 \mathrm{Ibid}$. For the general and local acts which set forth the jurisdiction of the Detroit justices at the time of consolidation, see SwEETMAN G. SMITH, Practice and Procedure of the Common Pleas Court of the City of Detrort (Chicago: Callaghan and Company, x938), §§ I-Io. Section 5: "original jurisdiction of all civil actions wherein the debt or damages do not exceed the sum of one hundred dollars," concurrent jurisdiction up to $\$ 500$, with certain exceptions. Exclusive where both parties reside in city, and in certain assigned actions. See act no. 475 , local acts 1903 , as amended and interpreted; SMITH, op. cit., § 6 especially.

58 The r 947 amending act was P.A. 259, 1947. The 1949 amendment was P.A. 149, 1949. As to the difficulties experienced through the lack of common pleas jurisdiction in actions against such municipal corporations as the Detroit Street Railway, see Ira W. Jayne, "The Mouse in the Mountain," The Detroit Lawyer, December, 1948.

${ }^{59}$ Compare Gustav L. Schramm, Piedpoudre Courts (Pittsburgh: The Legal Aid Society, r928), p. ro5 et seq.; and Reginald Heber Smith, JusTICE AND THE Poor (New York: I919), chap. VIII, especially p. 55. 
c. Criminal Jurisdiction

The common pleas court has such jurisdiction "in all suits . . . both civil and criminal ... as was . . exercised by the justices . . . immediately prior to the consolidation. . ." Since justices of the peace have the preliminary jurisdiction of magistrates throughout the county in which they operate, this language enables common pleas justices to conduct preliminary examinations of defendants charged with criminal offenses within Wayne County. ${ }^{\text {e1 }}$ Since recorder's court has exclusive jurisdiction within the city, however, common pleas judges may conduct examinations only for offenders charged outside the city limits. In 1947, thirty-two such examinations were conducted; in 1948, fifty. ${ }^{62}$ This exercise of county criminal jurisdiction by a civil city court is an interesting example of the haphazard development of a court in a metropolis in response to the ingenuity and convenience of counsel.

Section 7. Jurisdiction of Minor Courts in the Metropolitan District Outside Detroit

From time to time minor courts have been organized in various cities in the district with a jurisdiction somewhat higher than that of justices of the peace.

\section{a. Flint Act City Courts}

Dearborn and Highland Park, both geographically adjacent to the city of Detroit, have consolidated city courts organized under a statute which permits cities with more than one justice of the peace and having a population

${ }^{60}$ 728. I Comp. Laws (1948); 27.365 I Mrch. Stats. Ann. (Supp.).

${ }^{61} 774.4$ CoMp. Laws (1948); 28.1195 Mich. Stats. AnN.

${ }^{62} 1947$ and 1948 Reports of the presiding judge to the Common Council of the city of Detroit. 
between 100,000 and 160,000 to consolidate their justices into a single tribunal. ${ }^{63}$

Both courts have exclusive civil jurisdiction of cases involving up to $\$ I O O$, and concurrent jurisdiction with the circuit court in matters where the amount in controversy does not exceed \$30o. The maximum amount may be increased, under a I 947 amendment, to \$1,000. Currently the maximum civil jurisdiction in Highland Park is $\$ 500$; in Dearborn, $\$ \mathrm{I}$, ooo. ${ }^{64}$

Both courts have exclusive criminal jurisdiction identical with that of city justices, including the power to act as examining magistrates for felonies throughout the county ${ }^{65}$ and to try and determine charges for offenses arising within the county and punishable by a fine of not over $\$$ I.OO and/or imprisonment in the county jail for not over three months. ${ }^{66}$ Authority to dispose of ordinance violations is conferred upon these courts by charter.

\section{b. Home Rule Act City Courts}

A home rule city, in Michigan, is a city which has voted to adopt the self-governing powers permitted by the statute, and by charter. Cities which have adopted home rule may, by charter amendment, adopt also a form of consolidated city court to supplant the justice of the peace system, as provided by a portion of the Home Rule Act. ${ }^{67}$ Certain cities, as shown at Table III, have proceeded to organize consolidated city courts under this statute. One city in the Detroit metropolitan district, however, though it has adopted home rule, has not organized a city court, but continues to operate with two justices. ${ }^{68}$

63 730.ror Comp. Laws (1948); 27.383 I Mich. Stats. Ann. (Supp.).

64 A 1947 amendment (P.A. I947, no. 264) increased the permissible maximum to $\$ \mathrm{I}, 000$. Information supplied by the two courts.

65 766.2-766.3 Comp. LaWs ( 1948 ) ; 28.920-921 Mich. Stats. AnN.

${ }^{66}$ 744.1 Comp. Laws (1948); 28.1192 Mich. Stats. Ann.

67 I 77.28-ir7.30 Comp. Laws (1948); 5.2107-5.21 ro Mrсh. Stats. Ann.

68 Table III, infra p. 54. The city referred to is Hamtramck. 
Home rule city courts have exclusive civil jurisdiction to $\$ 100$, and concurrent civil jurisdiction with the circuit court to $\$ 300$, which may be increased by charter to $\$ 500 .{ }^{69}$ Their criminal jurisdiction is the same as that of justices of the peace, including authority to act as examining magistrates for offenses arising in the county, and authority fully to try and determine offenses punishable by a fine of not over $\$ I O O$ and/or county jail imprisonment for not more than three months, where such offenses arise in the county. ${ }^{20}$ These courts have authority to dispose of ordinance violations as provided by charter, within the penalty limitations above set forth.

\section{c. City Justices Outside Detroit}

In several cities in the area, as shown by Table III, the justices of the peace have not been supplanted or consolidated into city courts, but act severally under the old justiceof-the-peace system. ${ }^{71}$

Each justice has original civil jurisdiction within the city up to $\$ 100$, concurrent to $\$ 300$, and this may be raised to $\$ 500$ by charter. ${ }^{72}$

Each justice has criminal jurisdiction to act as examining magistrate for matters beyond justice jurisdiction throughout the county, together with jurisdiction to dispose of offenses arising within the county and punishable by $\$ 100$ fine and/or three months in the county jail. Criminal jurisdiction also includes such authority to determine and dispose of ordinance violations as is provided by charter, within the penalty limitations set forth. ${ }^{73}$

69 Supra n. 67.

${ }^{70}$ 766.2-766.3 Comp. LaWs (1948); 28.920-28.92x Mich. Stats. Ann.

71 Constitution of Michigan (Igo8), art. VII, \& I6; 666.r Comp. LaWs (1948), 27.3179 Mich. Stats. ANN. (civil) ; 766.2-766.3 Comp. Laws (1948), 28.920-28.921 Mich. Stats. AnN. (criminal); and see also 774.x Comp. Laws (1948), 28.1192 Mich. Stats. Ann.

72 Ibid. (civil).

${ }^{73}$ Supra n. 71 (criminal). 
d. Township Justices in the Detroit Metropolitan District

The I04 township justices in the metropolitan district act for villages within their respective townships. Their civil jurisdiction is original and exclusive up to $\$ 100$, concurrent with the circuit court up to $\$ 300 .{ }^{74}$ They may act as examining magistrates for felonies committed within the county; they may determine criminal offenses occurring in the county and punishable by not more than $\$$ roo fine and/or not more than three months in the county jail. ${ }^{75}$

e. Distribution of Minor Courts in the Detroit Metropolitan District

Table III shows the extent of consolidation and of enlarged monetary jurisdiction within the Detroit area.

Thus, of the twenty-seven cities (besides Detroit) in the metropolitan district, thirteen have established consolidated courts and the other fourteen retain the justice of the peace system.

As to the fourteen cities which retain the justice system, it is interesting to note that in four cities, the population is sufficiently large so that there are two justices in each. This makes a total of eighteen justice courts in the metropolitan area. The maximum civil jurisdiction of these eighteen justice courts is distributed as follows: twelve courts (nine cities) have a maximum of $\$ 500$; six courts (five cities) have a maximum of $\$ 300$. Note especially that Hamtramck, which is a civic island entirely surrounded by

74 Constitution of Michigan (rgo8), art. VII, $\S \mathrm{r6} ; 666 . \mathrm{r}-666.6$ Comp. LAws (1948), 27.3179-27.3184 Mich. STATs. ANN, and supra n. $7 \mathrm{r}$.

Justices have no jurisdiction of real actions, or of actions against municipal corporations, or of equitable actions. But see Edson R. Sunderland, "A Study of Justices of the Peace and Other Minor Courts-Requisites for an Adequate State-Wide Minor Court System," Fiftennth Annual Report of the Judicial Council of Michigan (October, r945), p. 9r et seq.

75 Supra n. 7 r. 
TABLE III

Consolidation and Civil Jurisdiction of City Courts in the Detroit Metropolitan District Excluding Detrolt

\begin{tabular}{|c|c|c|c|c|}
\hline County & City & Type of court & $\begin{array}{l}\text { Maximum } \\
\text { amount in } \\
\text { controversy }\end{array}$ & $\begin{array}{l}\text { Number } \\
\text { of } \\
\text { justices }\end{array}$ \\
\hline \multirow[t]{11}{*}{ Wayne } & Dearborn & Flint Act & $\$ \mathrm{I}, \mathrm{OOO}$ & \\
\hline & Ecorse & Justice of peace & 500 & 2 \\
\hline & Garden City & “" " & 300 & \\
\hline & Grosse Pointe & " $6 " 6$ & 300 & 2 \\
\hline & Hamtramck & " $\quad$ " & 500 & 2 \\
\hline & Highland Park & Flint Act & 500 & \\
\hline & Lincoln Park & Home Rule Act & 500 & \\
\hline & Melvindale & Justice of peace & 500 & \\
\hline & Plymouth & Home Rule Act & 500 & \\
\hline & River Rouge & "6 "6 & 500 & \\
\hline & Wyandotte & " " & 500 & \\
\hline \multirow[t]{12}{*}{ Oakland } & Berkeley & Justice of peace & 500 & \\
\hline & Birmingham & Home Rule Act & 500 & \\
\hline & Bloomfield Hills & “ $\quad$ " & 500 & \\
\hline & Clawson & Justice of peace & 500 & \\
\hline & Farmington & Home Rule Act & 500 & \\
\hline & Ferndale & Justice of peace & 500 & \\
\hline & Huntington Woods & 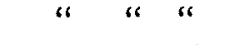 & 300 & \\
\hline & Oak Park & Home Rule Act & 500 & \\
\hline & Pleasant Ridge & Justice of peace & 500 & \\
\hline & Pontiac & Home Rule Act & 500 & \\
\hline & Royal Oak & " $"$ " & 500 & \\
\hline & Sylvan Lake & Justice of peace & 300 & \\
\hline \multirow[t]{4}{*}{ Macomb } & Mount Clemens & $\begin{array}{l}\text { Home Rule Act } \\
\text { ( } 1947)\end{array}$ & & \\
\hline & East Detroit & Justice of peace & 500 & 2 \\
\hline & Center Line & " " " " & 500 & \\
\hline & Utica & "6 "6 6 & 300 & \\
\hline
\end{tabular}

the city of Detroit, retains its two individual justices, although it has adopted home rule.

Of the thirteen cities with consolidated courts, six are in Wayne County, six in Oakland County, one in Macomb County; one has a maximum civil jurisdiction of $\$ \mathrm{r}, 000$; 
twelve have a maximum civil jurisdiction of $\$ 500$. No consolidated court retains the $\$ 300$ limit.

f. Tendency Toward Enlargement of Jurisdiction of Minor Courts

There is a tendency for minor courts in this area to aggrandize their jurisdiction by seeking to augment the maximum monetary jurisdiction-a tendency to grow away from their original function of a tribunal for the determination of small claims.

The court of common pleas in Detroit is the only court in the area which has reached a maximum as high as $\$ \mathrm{I}, 500$. Its original maximum under the 1929 act was $\$ \mathrm{I}, 000$. Dearborn, adjoining Detroit, raised its maximum in 1947 to $\$ 1,000$, and Highland Park, adjoining Detroit, will submit to its electorate soon the question of raising its jurisdiction to $\$ \mathrm{I}, 000$. On the other hand, Hamtramck, also adjoining Detroit, remains under individual justices and with a $\$ 500$ maximum with no plans for immediate enlargement or consolidation. 


\title{
Chapter III
}

\section{Organization of Courts in the Detroit Metro- politan District: Judicial Personnel}

\author{
Section i. Qualificatrons of Judges
}

\section{a. Circuit Court}

\section{7}

THERE are no statutory professional qualifications at present for Michigan circuit court judges. A statute enacted in 1935 required all circuit judges in Michigan to be practicing attorneys with at least eight years' experience in the practice of law. ${ }^{1}$ The statute was held unconstitutional in 1937 by the state supreme court ${ }^{2}$ on the theory that the "judiciary is an independent department of the State government and the legislature has no power to annex qualifications for circuit judges not found in the Constitution."

The educational and judicial qualifications of the present judges of the Circuit Court of Wayne County are set forth in Tables IV and V.

All the present eighteen judges have been admitted to the Michigan bar.

One judge has for many years taught law at one of the Detroit law schools.

Several judges have had pre-judicial public experience related to their judicial qualifications: thus, one judge served as United States congressman for two years and as state

1 602.40 Comp. Laws (1948); 27.171 Mich. Stats. Ann.

2 Attorney General ex rel Cook v. O'Neill, z8o Mich. 649 (r.937).

3 At p. 658 . For an instance of legislative interference with judicial function, see 602.58 Comp. Laws (x948), 27.I95 Mich. Stats. AnN., requiring that circuit and recorder's court judges sign a statement to the effect that they have their work up to date before receiving their pay checks. 
TABLE IV

Legal Education of Judges of the Circuit Court of Wayne County (1948)

\begin{tabular}{|c|c|}
\hline $\begin{array}{l}\text { Name of } \\
\text { institution }\end{array}$ & $\begin{array}{c}\text { Number of } \\
\text { judges } \\
\text { graduated }\end{array}$ \\
\hline Detroit College of Law .... & $\ldots 8$ \\
\hline University of Detroit Law School. & 5 \\
\hline University of Michigan Law School. & 5 \\
\hline Harvard Law School........... & 1 \\
\hline Boston University Law School. & I \\
\hline
\end{tabular}

TABLE $V$

Judicial Experience of Wayne County Circuit Court JUDGES ( 1948 )

\begin{tabular}{|c|c|c|c|}
\hline $\begin{array}{c}\text { Judge } \\
\text { (designated } \\
\text { by number) }\end{array}$ & $\begin{array}{c}\text { Years of } \\
\text { judicial service } \\
\text { before becoming. } \\
\text { circuit judge }\end{array}$ & $\begin{array}{c}\text { Years of } \\
\text { judicial service } \\
\text { as circuit } \\
\text { judge }\end{array}$ & $\begin{array}{c}\text { Total } \\
\text { years of } \\
\text { judicial } \\
\text { service }\end{array}$ \\
\hline I & & 24 & 24 \\
\hline 2 & I8 (recorder's) & 4 & 22 \\
\hline 3 & & I & I \\
\hline 4 & 5 (common pleas) & 4 & 9 \\
\hline 5 & & I 8 & 18 \\
\hline 6 & 5 (justice of peace) & 28 & 33 \\
\hline 7 & & I & I \\
\hline 8 & & 27 & 27 \\
\hline 9 & & $3 I$ & $3 I$ \\
\hline IO & & 30 & 30 \\
\hline I I & Io (justice of peace) & 27 & 37 \\
\hline 12 & & 25 & 25 \\
\hline 13 & & 19 & 19 \\
\hline $1_{4}$ & & 3 & 3 \\
\hline I 5 & & 7 & 7 \\
\hline 16 & I6 (justice of peace) & 6 & 22 \\
\hline 17 & & 5 & 5 \\
\hline 18 & 8 (traffic) & 3 & I I \\
\hline Total & $\overline{62}$ & $\overline{263}$ & $\overline{325}$ \\
\hline
\end{tabular}

senator for a year, another was state senator for six years, another was circuit court commissioner for six years, still another spent eight years in the office of the prosecutor of 
Wayne County, first as assistant county prosecutor and then as prosecutor.

One judge (he who has taught and is teaching law) has served as a school executive, a member of the state school board, and in an executive capacity in public and private social agencies.

\section{b. Probate Court}

There are no statutory qualifications, but the actual qualifications of the present Wayne County probate judges, including the judge of the juvenile court are shown in Tables VI-VII. All six judges have been admitted to the Michigan bar.

\section{TABLE VI}

Legal Education of Wayne County Probate and Juvenile Court Judges ( I948)

Name of institution

Number of judges graduated

Detroit College of Law.................. 2

University of Detroit Law School............... 3

Indiana University Law School................ I

\section{TABLE VII}

Judicial Experience of Wayne County Probate and Juvenile Court Judges (1948)

\begin{tabular}{|c|c|c|c|}
\hline $\begin{array}{c}\text { Judge } \\
\text { (designated } \\
\text { by number) }\end{array}$ & $\begin{array}{l}\text { Years of } \\
\text { judicial service } \\
\text { before becoming } \\
\text { probate judge }\end{array}$ & $\begin{array}{c}\text { Years of } \\
\text { judicial service } \\
\text { as probate } \\
\text { judge }\end{array}$ & $\begin{array}{c}\text { Total } \\
\text { years of } \\
\text { judicial } \\
\text { service }\end{array}$ \\
\hline I & Io (circuit court) & 9 & 19 \\
\hline 2 & & 15 & I 5 \\
\hline 3 & & I5 & 15 \\
\hline 4 & & I 3 & 13 \\
\hline 5 & & 2 & 2 \\
\hline 6 & & $\mathbf{I}$ & $\mathbf{I}$ \\
\hline & - & - & - \\
\hline Tota & 10 & 55 & 65 \\
\hline
\end{tabular}


One judge was attorney general of Michigan. The judge who has been on the bench only a year has been an executive of the probate court for fifteen years.

\section{c. Recorder's Court}

There are no statutory or charter qualifications, but the actual qualifications of the present recorder's court judges are shown in Tables VIII-IX.

\section{TABLE VIII}

Legal Education of Recorder's Court Judges ( i948)

Name of institution

Number of judges graduated

Detroit College of Law................. 5

University of Detroit Law School............... I

University of Michigan Law School............... 3

Yale Law School....................... I

\section{TABLE IX}

Judicial Experience of Recorder's Court Judges (1948)

\begin{tabular}{|c|c|c|c|}
\hline $\begin{array}{c}\text { Judge } \\
\text { (designated } \\
\text { by number) }\end{array}$ & $\begin{array}{l}\text { Years of } \\
\text { judicial service } \\
\text { before becoming } \\
\text { recorder's } \\
\text { court judge }\end{array}$ & $\begin{array}{l}\text { Years of } \\
\text { judicial service } \\
\text { as recorder's } \\
\text { court judge }\end{array}$ & $\begin{array}{c}\text { Total } \\
\text { years of } \\
\text { judicial } \\
\text { service }\end{array}$ \\
\hline I & I2 (common pleas) & 16 & 28 \\
\hline 2 & & 49 & 49 \\
\hline 3 & & 22 & 22 \\
\hline 4 & 7 (traffic) & 12 & 19 \\
\hline 5 & I4 (common pleas) & 4 & 18 \\
\hline 6 & & I7 & 17 \\
\hline 7 & 8 (common pleas) & 8 & 16 \\
\hline 8 & & 12 & 12 \\
\hline 9 & 6 (common pleas) & 2 & 8 \\
\hline IO & & 3 & 3 \\
\hline Total & $\overline{47}$ & $\overline{145}$ & $\overline{192}$ \\
\hline
\end{tabular}


All ten judges have been admitted to the Michigan bar. Several (three at this writing) are teaching in Detroit law schools; others have previously done so.

One judge is a former city editor of the Detroit Free Press, two are former assistant attorneys general of the state of Michigan, two have been assistant county prosecutors of Wayne County, one is a former assistant United States district attorney.

\section{d. Traffic Court}

There are no statutory or charter qualifications. Tables $\mathrm{X}$ and $\mathrm{XI}$ show the actual qualifications.

\section{TABLE $\mathrm{X}$}

Legal Education of Traffic Court Judges ( 1948 )

$$
\begin{gathered}
\text { Name of } \\
\text { institution }
\end{gathered}
$$

\begin{tabular}{|c|c|c|c|}
\hline $\begin{array}{c}\text { Judge } \\
\text { (designated } \\
\text { by number) }\end{array}$ & $\begin{array}{c}\text { Years of } \\
\text { judicial service } \\
\text { before becoming } \\
\text { traffic court } \\
\text { judge }\end{array}$ & $\begin{array}{l}\text { Years of } \\
\text { judicial } \\
\text { experience as } \\
\text { traffic court } \\
\text { judge }\end{array}$ & $\begin{array}{c}\text { Total } \\
\text { years of } \\
\text { judicial } \\
\text { service }\end{array}$ \\
\hline $\mathbf{I}$ & $\begin{array}{l}6 \text { (circuit court } \\
\text { commissioner) }\end{array}$ & I 2 & I 8 \\
\hline 2 & I2 (common pleas) & 3 & 15 \\
\hline Total & $\overline{18}$ & - & $\overline{33}$ \\
\hline
\end{tabular}

Detroit College of Law .................. I

University of Michigan Law School.............. I

\section{TABLE XI}

Judicial Experience of Traffic Court Judges ( I948)

Both judges have been admitted to the Michigan bar. One judge has served as assistant county prosecutor of Wayne County. 
e. Court of Common Pleas of Detroit

A statute requires that judges be attorneys with four years' experience in the practice of law. Actual qualifications of the present judges are as follows:

\section{TABLE XII}

Legal Education of Common Pleas Judges ( 1948)

Name of institution

Number of judges graduated

Detroit College of Law.................. 5

University of Detroit Law School............... I

University of Michigan Law School.............. 2

Harvard Law School...................... I

All nine judges have been admitted to the Michigan bar. One judge has been prosecutor for Wayne County, one has been legal adviser to the governor, one has been an assistant attorney general of the state of Michigan.

\section{TABLE XIII}

Judicial Experience of Common Pleas Judges (1948)

$\begin{array}{cccc}\begin{array}{c}\text { Judge } \\ \text { (designated } \\ \text { by number) }\end{array} & \begin{array}{c}\text { judicial service } \\ \text { before becoming } \\ \text { common pleas } \\ \text { judge }\end{array} & \begin{array}{c}\text { Years of } \\ \text { judicial service } \\ \text { as common } \\ \text { pleas judge }\end{array} & \begin{array}{c}\text { Total } \\ \text { years of } \\ \text { judicial } \\ \text { service }\end{array} \\ \text { I } & & 25 & 25 \\ 2 & & 25 & 25 \\ 3 & & 20 & 20 \\ 4 & & 13 & 13 \\ 5 & & 4 & 4 \\ 6 & & 4 & 4 \\ 7 & & 3 & 3 \\ 8 & & 3 & 3 \\ 9 & & 2 & 2 \\ \text { Total } & & - & - \\ \end{array}$

* Including years of service as Detroit city justice prior to consolidation of justices into common pleas court. 
Despite lack of statutory requirements, it is noted that all of the Detroit judges are members of the Michigan bar. Thirty-one out of forty-five judges sitting in Detroit have obtained law degrees from schools in the city of Detroittwenty-one from Detroit College of Law, ten from the University of Detroit. Eleven judges received law degrees from the University of Michigan. Five judges received law degrees from schools outside the state of Michigan-two from Harvard, one from Boston, one from Yale, one from Indiana.

The average judge had fifteen years of judicial experience at the time the figures were assembled in April of 1948.

f. Qualifications of Judges of Minor Courts in the Metropolitan District outside the City of Detroit

Judges of Flint Act ${ }^{4}$ municipal courts are required to be attorneys with five years' experience in the practice of law. ${ }^{5}$

Judges of home rule ${ }^{6}$ city courts must be attorneys admitted to practice. ${ }^{7}$

City justices are subject to no statutory qualifications, but some cities impose certain requirements by charter provision. ${ }^{8} \mathrm{Of}$ the eighteen city justices at present in the metropolitan district, three are members of the bar.

${ }^{4}$ For list of such courts in the metropolitan district, see table III, p. 54. Since the Constitution of Michigan, art. VII, $\S 15$, permits the making of legal requirements relative to justices of the peace, this statute and other statutory and charter requirements like it, should survive application of the rule in the O'Neill case, supra n. 2.

5 720.103 Comp. LaWs (1948); 27.3833 Mrch. Stats. Ann.

${ }^{6}$ For list of such courts in the metropolitan district, see table III, supra p. 54 .

7 Melvindale, Ferndale, and Pontiac, for example, require five years' experience. See table III, supra p. 54 .

${ }^{8}$ According to the STATE BAR LIST of the Michigan Bar Association and the 1948 edition of Martindale-Hubbell's Directory of Attorneys. 
Section 2. Age of Judges

The ages of the forty-five judges sitting in the city of Detroit in 1948 are shown in the following table:

\section{TABLE XIV}

\section{Age of Detroit Judges}

$\begin{array}{lllllll}\text { Court } & 30-40 & 4 \mathbf{1}-50 & 5 \mathbf{x}-60 & 6 \mathbf{I}-70 & 7 \mathbf{x}-80 & \text { Over } 80\end{array}$ Circuit ...........

Probate, Juvenile ...... . 3

Recorder's, Traffic ...... .

Common Pleas ...... I 1

Total $\ldots \ldots \ldots \ldots+\frac{1}{1} \quad \frac{3}{12} \quad \frac{-}{15} \quad \frac{1}{12} \quad \frac{-}{4} \quad-$

The age of the median judge is between fifty and sixty.

* $\quad * \quad *$

There is no retirement plan for Michigan judges at this writing, although a bill to include circuit and recorder's court judges in the public employees' retirement annuity plan has been submitted to the last several sessions of the legislature. Michigan is one of seventeen states which do not yet provide for judicial retirement pensions. ${ }^{9}$

\section{Section 3. Methods of Selecting Judges}

All judges in Michigan are elected. A constitutional provision $^{10}$ requires all county judicial officers to be elected on a nonpartisan ticket. This covers circuit, probate, and recorder's court judges, but not common pleas judges, justices of the peace, or successors to justices. ${ }^{11}$

931 Journal of the American Judicature Societr, February, I948, 148-49, table I. See Burke Shartel, "Retirement and Removal of Judges," 20 Journal of the American Judicature Society, December, 1936, 133-153; and "Federal Judges-Appointment, Supervision, and Removal-Some Possibilities under the Constitution," 28 Michigan LAw Review, March, April, May, 1930, 485-529, 723-38, 870-909.

10 Constitution of Michigan (1908), art. VII, $\S 23$ as amended.

11 Baird v. Election Commission, 316 Mich. 657 (1947). 


\section{a. Selection of Circuit Court Judges}

Circuit judges in Michigan are elected at state elections held every sixth year. ${ }^{12}$ The terms of judges on multi-judge courts are not staggered: the entire circuit bench of the state comes up for re-election at the same time. Vacancies are filled by gubernatorial appointment; the appointment runs until the next county election, at which time the voters select a judge to hold office until the terms of all the incumbent circuit judges expire. ${ }^{13}$

\section{b. Selection of Probate Judges}

Probate judges are elected for four-year terms, at county elections. ${ }^{14}$ In Wayne County only, the terms of the six judges are staggered three and three. ${ }^{15}$ The juvenile court judge is not designated as such by the voters.

\section{c. Selection of Recorder's Court Judges}

The number of judges to be elected is determined on the basis of one judge for each 85 ,0oo population or a majority fraction thereof, according to the federal census for the year 1920. The recorder is specially designated on the ballot. All ten judges are elected at a general nonpartisan election for city officers. All judges serve six-year terms, and the terms are not staggered. Vacancies are filled by appointment by the governor until the next municipal elec-

12 Constitution of Michigan (1908), art. VII, $\S 9$; r7r.1o Comp. Laws (1948); 6.270 Mich. Stats. Ann.

13 Constitution of Michigan (1908), art. VII, $\$$ I9-20; 201.34 Comp. Laws (1948); 6.7 I4 Mich. Stats. AnN.

14 Constitution of Mrchigan (rg08), art. VII, $\S 14 ;$ ry 1 .6 Comp. Laws (1948); 6.266 Mich. Stats. Ann.; 701.I-701.2 Comp. LaWs (1948); 27.3 $178(1)-27.3 \times 78(2)$ Mich. Stats. AnN.

15 7or.2 Comp. LaWs (1948); 27.3178(2) Mrch. Stats. Ann. (Supp.): "In counties having more than $x, 000,000$ inhabitants there shall be 6 judges of probate, 3 of whom shall be elected at each alternate biennial election for terms of 4 years each." 
tion, when the voters elect a judge to fill each unexpired term. ${ }^{16}$

d. Selection of Judges of the Traffic and Ordinance Court

Two traffic and ordinance judges are nominated and elected at municipal elections in the same manner as the judges of the criminal division, but "under separate ballot designation of judges of the municipal court-traffic and ordinance division." 17

e. Selection of Judges of the Court of Common Pleas of Detroit

Nine common pleas judges are now serving this court; this number constitutes the statutory maximum. Four are elected at a biennial city election; five at the next biennial city election. Each judge serves a six-year term. The present staggering of the terms is the result not of the common pleas court statute but of the fact that when the court was created, the city justices already serving became judges of the court of common pleas, and served out their terms in the new capacity. These justice terms happened to expire at different times. ${ }^{18}$

Common pleas justices are not county judicial officials, and hence are not covered by the nonpartisan election requirement imposed on such officers. ${ }^{19}$ Vacancies are filled by appointments by the governor, which run until the next city election, when voters select judges to fill out each unexpired term. ${ }^{20}$

16 725.1; Comp. Laws (1948); 27.394I Mich. Stats. Ann. See O'Hagan, $\circ p$. cit., pp. $12, \mathrm{x}_{3}$, for a complete legislative history and collation of the various public and private acts and charter provisions.

${ }^{17} 725.8$ Comp. Laws (I948); 27.3948 Mich. Stats. Ann. O'Hagan, loc. cit.

18728.2 Comp. Laws (x948); 27.3652 Mich. Stats. Ann.

${ }^{19}$ Baird v. Detroit Election Commission, 316 Mich. 657 (I947).

${ }^{20} 730.102$ Comp. Laws (1948);27.3832 Mich. Stats. Ann. 
f. Selection of Judges in Home Rule Cities

These judges are elected "in the manner the mayor of the city is nominated and elected" for a six-year term. ${ }^{21}$

\section{g. Selection of Judges in Flint Act Cities}

Judges in Highland Park and Dearborn are elected at city elections for four-year terms. ${ }^{22}$

\section{h. Selection of City Justices}

In cities not under home rule or covered by special statute, justices are elected as other city officers are.

\section{i. Selection of Township Justices}

There may be four justices in each township. Township elections occur biennially. When a justice's term has expired, or where the voters wish to elect another justice in territories already served by less than four justices, as many justices as necessary to bring the number up to four may be elected at any biennial township election. Each justice serves four years. Vacancies may be filled by the township board, pending the next township election. ${ }^{23}$

\section{j. Comment on Methods of Selecting Judges}

The nonpartisan election requirement demonstrates a desire to free the judiciary from the disadvantages of political machination. In the case of the Detroit and Wayne County judges, it is pointed out by court personnel that the size of the electorate and the unfamiliarity of the average voter with the professional records of candidates result in a practical disadvantage: where the party leaders pick

\footnotetext{
21 I 7 7.28 Comp. Laws (1948); 5.2107 Mrch. Stats. Ann.

22 Constitution of Michigan, art. VII, $\$ 15$.

2385.5 Comp. Laws (1948); 5.1627 Mich. Stats. ANn.
} 
the candidates, at least there is some preliminary screening. The nonpartisan ballot in Detroit has nourished the development of a phenomenon known locally as "name" candidacies-the running of unknown persons who have names identical with or confusingly similar to those of persons with established records. It is felt that a record of good performance on a bench may avail a candidate little under the nonpartisan system in an area containing a city the size of Detroit.

The system of having the governor fill vacancies raises another problem in Detroit. The political machinations banished by the partisan ballot may re-enter here; in a community the size of the Detroit area they would be difficult to detect, and almost impossible to stop.

The existence of multi-judge benches which are not staggered as to term is striking in Detroit. Regarded as very bad by some scholars, ${ }^{24}$ this system is defended by court personnel on the pragmatic ground that where the terms are not staggered, the routine of the court is less often interrupted, and the judges subjected to less unwholesome political pulling and hauling, than would otherwise be the case. In the city of Detroit, for instance, the entire benches of three courts-eighteen judges on the circuit court, ten on the recorder's court, two on the traffic and ordinance court-and some of the probate and common pleas judges come up for re-election at the same time. Although the circuit judges are elected at a county election, and the recorder's court judges at a city election, the elections actually take place at the same time, in the same year, in Detroit, in the spring. The elected judges take office the following January.

We are informed by members of the bar and the bench

24 W. F. Willoughby, Principles of Judicial Administration (Washington: The Brookings Institution, 1929), p. 29r: "A vicious system...." 
in Detroit that it is occasionally difficult, during election year, to obtain the undivided attention of the court personnel for the disposition of litigation.

Scholarly comment on the efficacy of various plans for the selection of judges is abundant. ${ }^{25}$

\section{Section 4. Compensation of Judges}

\section{a. Compensation of Circuit Judges}

All circuit judges receive a monthly salary from the state of Michigan. In addition, they are permitted by a constitutional provision to receive from their respective counties whatever sum is found appropriate by the board of supervisors thereof, provided the sum be the same for all judges in the same county. ${ }^{26} \mathrm{~A}$ statute placed a ceiling of $\$ 13,500$ per annum on the total sum which Wayne County judges might receive from all sources, but the statute is regarded as in contravention of the constitutional power of the county to pay what it sees fit. ${ }^{27}$

All circuit judges throughout the state receive $\$ 7,000$ a year from the state. Until 1947 it was $\$ 6,000$. At this writing the Michigan legislature is considering a bill which will again raise the annual salaries of circuit judges.

The total salary of each Wayne County circuit judge in 1947 was $\$ 16,500$. In $192 \mathrm{I}$, each received a total of $\$ 11,500$; in $1924, \$ 13,500$; in $1929, \$ 14,500$; in $194 \mathrm{I}$, $\$ 15,500$. In New York, judges of comparable jurisdiction received $\$ 25,000$ in 1947 ; in Chicago, $\$ 17,000$.

The total salary of each Oakland County circuit judge

25 Willoughby, op. cit., pp. 36rm83; Evan Haynes, The Srlection and Tenure of Judges (The National Conference of Judicial Councils, r944); and Roscon Pound, Organization of Courts (Boston: Little, Brown and Company, r940), p. $\times 56$.

26 Constitution of Michigan (1908), art. VII, $\$$ r2.

27 602.41 Comp. Laws (1948); 27.172 Mrch. Stats. Ans. No judge may receive extra compensation for holding court in another circuit while acting as visiting judge: 602.58 Comp. LaWs (1948); 27.r95 Mich. Stats. Ann. 
in 1947 was \$1 2,000; of each Macomb County circuit judge, $\$ 8,5$ oo.

\section{b. Compensation of Probate Court Judges}

Under the 1947 statute, the basic annual salaries of probate judges, which differ in counties of different population, were as follows: Macomb County, \$5,000; Oakland County, \$6,0oo; Wayne County, \$8,400. Probate judges are paid entirely by the county. The statute further provides that each county may pay its probate judges, in lieu of fees, additional amounts in salary. ${ }^{28}$

In 1947 , the total salary paid to each probate judge in Wayne County was $\$ 13,500$.

\section{c. Compensation of Juvenile Court Judge}

Wayne County is the only county in the metropolitan district with a separate juvenile court judge; in 1947 he received $\$ \mathbf{I} 3,5$ oo.

\section{d. Compensation of Recorder's Court Judges}

Recorder's court judges are paid $\$ 7,000$ annually by the county for services rendered in felony cases, and are per-

${ }^{28}$ 7or.4 Comp. Laws (1948); 27.3178(4) Mich. Stats. Ann. (Supp.). "Said annual salary shall be, for counties having a population of 300,000 and upwards, $\$ 8,400,00$; for counties having a population of 250,000 and less than $300,000, \$ 6,000 \ldots$ for counties having a population of roo,000 and less than I $50,000 \$ 5,000 \ldots$..." et cetera.

". . . in addition thereto the judges of probate in each county, excepting counties having more than 3 judges of probate, shall receive for their services as judges of juvenile court, in addition to their regular salary, the sum of $\$ 300.00$ per annum for each 15,000 inhabitants . . . in their respective counties. ..."

"The board of supervisors of any county may ... give such additional salary to the judge of probate . . . as shall be deemed just by such board."

Right to fees, see 701.17 Comp. Laws (1948); 27.3178(17) Mich. Stats. ANN. In all three counties in the Detroit metropolitan district, the county pays its probate judges, in lieu of fees, a salary in excess of the statutory base, as above set forth. Fees, therefore, in the district, are paid in to the county after collection by the court. 
mitted to receive additional amounts from the city. ${ }^{29}$ The total salary in 1947 of the recorder's court judges was $\$ 16,3$ oo each, in addition to which the recorder receives an additional $\$ 2,000$ from the city.

The recorder's court judges' salaries have recently been equalized with those of the Wayne County circuit judges. In I92 I, recorder's court judges received \$I 1,500 apiece; in $1930, \$ 12,500$. In $194 \mathrm{I}$, they were raised to $\$ \mathrm{I}_{3}, 500$, but did not immediately receive the benefits of that or of the later increase because of a constitutional provision prohibiting any public officer except a circuit judge from receiving an increase in emolument during incumbency. ${ }^{30}$

\section{e. Compensation of Traffic and Ordinance Court Judges}

Traffic and ordinance judges are now paid the same amount as the recorder's court judges in the criminal court. They formerly received less than half as much from the city as their colleagues, but have recently been placed on an equal basis. ${ }^{31}$

\section{f. Compensation of Common Pleas Judges}

There is no statutory provision regulating these salaries. The city council, which paid its common pleas judges

29725.13 Comp. Laws (I948); 27.3953 Mich. Stats. AnN., which is a portion of the Municipal Court Act, provides that each judge is to be paid by the city an annual amount equal to that paid to circuit judges by the state, and such additional salary as the common council may see fit. This section, however, was not adopted by referendum, and thus the law in force is the original section, which provides that each judge shall receive from the county an amount equal to the amount paid by the state to circuit judges, together with an additional sum from the city as fixed by the common council. See O'HAGAN, $o p$. cit., pp. $\mathbf{1 - 8}$, for the legislative history.

${ }^{30} \mathrm{Ibid}$, for complete history of the successive stages in the financial development as related to judges' salaries. Constitution of Michigan (igo8), art. XVI, § 3 .

31 O'HAGAN, $o p$. cit., p. 6, for the legislative history. A previous statute provided for a smaller salary for each traffic and ordinance judge. The present statute is without this discriminatory language, so that judges of the traffic and ordinance division are now paid in the same manner as those on the criminal side of the bipartite tribunal. 
$\$ 6,000$ in $192 \mathrm{I}$, increased their salaries to $\$ 8,000$ in 1926 , to $\$ 8,500$ in 1927 , to $\$ 10,500$ in 1945 , and to $\$ 12,500$ in 1947. Since the judges have ascended the bench at various times, and since they are covered by the constitutional prohibition against receiving an increase during a term of office, the present judges receive amounts varying from $\$ 8,000$ to $\$ \mathrm{I} 2,500$ from the city of Detroit. ${ }^{32}$

g. Compensation of Judges of Minor Courts in the Area outside the City of Detroit

Judges of Flint Act city courts ${ }^{33}$ are paid salaries fixed by the city charter, ${ }^{34}$ and judges of home rule city courts ${ }^{35}$ are paid salaries fixed by the governing body of the city. ${ }^{36}$ The fees collected are paid into the city or county treasury. ${ }^{37}$ City justices in some cities ${ }^{38}$ are paid salaries, in others the fee system prevails. ${ }^{39}$ Township justices are paid fees as fixed by statute. ${ }^{40}$

\section{h. Comment on Compensation of Judges}

The rapid successive increases in salary received by judges sitting in Detroit parallel the rapid increase in population of the city and in the case load of the courts located in that city.

32 Constitution of Michigan (1908), art. XVI, § 3.

${ }^{33}$ For list of courts, see table I, p. 6.

${ }^{34}$ 73o.ro3 Comp. Laws (r948); 27.3833 Mich. Stats. Ann.

35 See table I, p. 6, for list of courts.

36 II7.28 Comp. Laws (I948); 5.2107 Mich. Stats. AnN.

37 Ibid.

38 For example, Hamtramck, Wyandotte, Melvindale, Ferndale, Birmingham, Clawson.

${ }^{39}$ For example, Utica, Center Line, Oak Park (although it has a home rule court), Berkeley, Pleasant Ridge, Huntington Woods, Ecorse, Grosse Pointe.

40 Civil: 677:I Comp. Laws (1948); 27.343 I Mich. Stats. AnN.-me.g,, $\$ 2.00$ a day for trying a cause, 25 each for docket entries.

Criminal: 775.2 Comp. Laws (1948); 28.1239 Mich. Stats. Ann.-e.g., $\$ 1.50$ for a guilty plea, $\$ 5.00$ a day for a full trial. 
Judges sitting in Detroit draw from $\$ 12,500$ to $\$ 16,500$, although some of the common pleas judges are still actually receiving less than $\$ 10,000$ because of the constitutional provision. ${ }^{41}$ The highest salary outside Detroit is $\$ 12,000$ for Oakland County circuit judges.

\section{Section 5. Organization of Judicial Personnel in Multi-Judge Courts}

\section{a. Nature of the Problem}

When a court has more than one full-time judge, the methods it adopts for division of labor and for co-operation in administrative matters have a large influence upon the character and efficiency of the tribunal. The existence of the multi-judge courts in the Detroit area gives rise to many of the problems which differentiate metropolitan from nonmetropolitan courts.

The problems of multi-judge courts do not arise where independent justices share the business in an area. In Ecorse, Grosse Pointe, and Hamtramck in Wayne County, and in East Detroit in Macomb County, the system of independent justices still obtains. Although in at least some of these places (Hamtramck and Ecorse, to our knowledge), the justices co-operate to the extent of sharing a clerk and a place for records, they do not experience the difficulties which occur when the business and responsibility of a single tribunal must be distributed among several judges and the performance of the judges checked for speed and quality.

Nor do such problems arise where a judge is supplied with a part-time associate. In Highland Park (a Flint Act court), an associate judge is used rather than two full-time judges with equal authority. In this court, the associate judge is an alternate who relieves the judge when his presence is impossible, and who is available in case of a

41 Constitution of Michigan (xgo8), art. XVI, § 3. 
suddenly jammed docket. In River Rouge, Wyandotte (both in Wayne County), Birmingham, Oak Park (Oakland County), and Mt. Clemens (Macomb County), all of which have Home Rule Act city courts, associate judges are provided for the purpose of insuring availability of a judge in case of the absence or incapacity of the judge himself. In like manner, associate justices of the peace, who are alternates in function, are attached to the respective justices of the peace of Berkeley and Ferndale, both in Oakland County. ${ }^{42}$

A number of courts in the metropolitan district are tribunals having several judges with equal authority. This requires them to deal with organizational and procedural problems which are common to multi-judge courts and which do not occur elsewhere-e.g., the use of administrative judges, the development of machinery for handling dockets, the development of specialized judges, divisions, and intracourt departments, the promulgation and enforcement of policy decisions with respect to the qualitative disposition of cases, and others.

Table XV lists the multi-judge courts in the Detroit metropolitan district.

All of the courts in Detroit are multi-judge courts except the juvenile court, a specialized division of the probate court which has become separated from the parental tribunal.

There are four courts sitting in Detroit with more than four judges each, and such courts occur nowhere else in the district. All the circuit courts in the district are multi-judge courts, but the only municipal court outside Detroit which has more than one judge is Dearborn, a geographic continuation of Detroit.

42 730.301-730.302 COMP. LAWS (1948); 27.4061-27.4062 MICH. STATs. Ann. (Supp.) ("Substitute Municipal Judges"); 730.321-730.328 CoMp. Laws (r948); 27.4071-27.4078 MrCh. STATs. ANN. (Supp.) ("Associate Justices or Associate Judges"). 
TABLE XV

Multi-Judge Courts in the Detroit Metropolitan District ( I948)

Court

Number of judges

Courts sitting in Detroit:

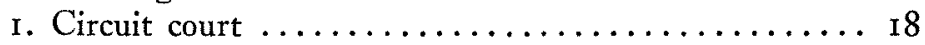

2. Recorder's court $\ldots \ldots \ldots \ldots \ldots \ldots \ldots \ldots \ldots$ ro

3. Common pleas court.................. 9

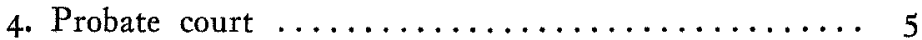

5. Traffic and ordinance court.............. 2

Court in Wayne County outside Detroit:

6. Dearborn city court.................. 2

Court in Oakland County outside Detroit:

7. Circuit court .................... 3

Court in Macomb County:

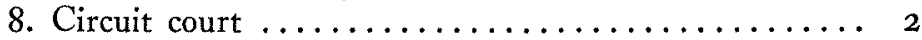

b. Methods Employed in the Several Multi-Judge Courts in the Detroit Metropolitan District

State-wide organization of circuit judges and recorder's court judges

All circuit judges in the state of Michigan belong to a group which annually elects a presiding circuit judge for the entire state. This judge has directory power to apportion the work of the several circuits among the circuit judges of the state. This authority may, at the request of the governor, be extended to include a designation by the state presiding judge of one or more judges to hold court in the various circuit courts and recorder's courts in the state whenever necessary to relieve congested conditions in said courts. ${ }^{43}$

Formerly, Wayne County was a substantial beneficiary: in I93 I, a total of 1,729 court days were spent by visiting judges in Wayne County; in 1932, 2,028 court days; in

43 691.201-691.202 CoMp. LaWs (1948); 27.291-27.292 Mich. Stats. Ann. 
1933, 592. In 1934, visiting circuit court judges accounted for 272 days in the Circuit Court of Wayne County, and recorder's court judges spent 375 court days on assignment in the circuit court-a total of 647 court days from outside judges. ${ }^{44}$

In 1944, visiting circuit court judges spent 20.5 court days in the Circuit Court of Wayne County. No recorder's court judges were assigned to the Circuit Court of Wayne County in 1944 or since. In 1946 , a total of I I 2 court days were spent in the Circuit Court of Wayne County by visiting circuit judges. In 1947, four court days were spent in the Circuit Court of Wayne County and thirty-three court days in the Traffic and Ordinance Court of Detroit, making a total of thirty-seven courtroom days spent in 1947 by visiting circuit court judges in Wayne County. ${ }^{45}$

The decline and present disuse of outstate judges for duty in courts sitting in Wayne County suggests the recognition of distinctive court problems in the central city of the metropolitan district.

\section{Circuit Court of Wayne County}

Presiding judge. A statute provides that in any circuit where there are more than two judges, the judges shall, from term to term, designate one of their number to act as presiding judge. The presiding judge has authority to "assign and apportion the business" of the court. ${ }^{46}$

A Wayne County court rule provides that the duly elected presiding judge shall serve until his successor shall

44 Sixth Annual Report of the Judicial Council of Michigan (May, r936), tables $V$ and VI, p. 54 .

45 Fifteenth Annual Report of the Judicial Council of Michigan (October, 1945), tables VI and VII, p. 46; Seventeenth Annual Report of the Judicial Council of Michigan (October, 1947), table VIII, p. 57; and Eighteenth Annual Report of the Jumicial Council of Michigan (September, 1948), table VI, p. 49.

46 602.53-602.54 CoMp. Laws (1948); 27.189-27.190 Mich. Stats. AnN. 
have been elected. ${ }^{47}$ The present presiding judge of the Circuit Court of Wayne County has been presiding judge for eighteen years.

A court rule ${ }^{48}$ defines his duties as follows:

"He shall have entire administrative control of the work of the court, supervision and charge of the calendar. $\mathrm{He}$ shall classify the cases, and make regulations governing the calendar, the calling and setting of cases for trial and the dismissal of cases in which no progress has been made for more than a year. Criminal cases shall always have precedence. He shall hear and determine all motions and matters arising under this delegation of authority. $\mathrm{He}$ shall also have immediate control and direction of the Assignment Clerk and staff."

The presiding judge keeps close control of the assignment and progress of cases; "no progress" cases are docketed separately and called before him once a month. He hears and determines motions for saving such cases. Appeal cases, also separately docketed, are called before the presiding judge daily, so that such cases may have docket priority. Motions for adjournment and for discontinuance of called cases are heard and determined by the presiding judge. ${ }^{49}$

The presiding judge arraigns all defendants in criminal cases, assigns these cases for trial, and pronounces sentence on convicted offenders. This enables the criminal docket to obtain precedence. ${ }^{50}$

Employees of the court are either under the supervision of the courtroom judge, if courtroom employees, or of the county clerk or assignment clerk. In practice, the county clerk clears matters touching upon employment with the

${ }^{47}$ Rules of the Circuit Court for the Third Judicial Circuit of Michigan (Wayne County), revised to April 1, 1948, part I, no. 4, p. 2.

48 Ibid., part I, no. 4, pp. 2-3.

49 lbid., part I, no. 3, p. 2 ; part II, nos. 1,2 , see also no. 5 .

50 Ibid., part I, no. 26 (a), p. 14. 
presiding judge. The assignment clerk is, as stated in the rule, directly responsible to the presiding judge. ${ }^{51}$

The presiding judge superintends the selection of jurors and has custody of the jury box. He assigns chancery reference matters to circuit court commissioners, and may require reports from the commissioners as to any aspect of their work. ${ }^{52}$

He presides at the regular monthly judges' dinner meeting, and there distributes to the judges monthly summaries of their attendance and performance record, which have been checked twice daily by the assignment clerk in person. The presiding judge assembles records, reports, and statistics on the work of the court, personally and through his immediate staff.

In general, then, the entire machinery of the circuit court is under the immediate control of the presiding judge of the Circuit Court of Wayne County, who bestows particularly minute attention upon the assignment, progress, and disposition of cases.

The present presiding judge does not devote all his time to the discharge of his duties in that capacity. $\mathrm{He}$ has the chancery pre-trial docket, also, and in addition carries a share of the work of trying cases. In January of 1947 , for instance, he tried 103 divorce cases. ${ }^{53}$

Pre-trial judges. The pre-trial hearing, as an American procedural device, originated in the Circuit Court of Wayne County. It is currently used as a required preliminary to the trial of all chancery and law cases in the Circuit Court of Wayne County. Chancery and law cases, when at issue, are placed respectively upon the chancery pre-trial docket or the law pre-trial docket, which are called daily before the pre-trial judges. These judges have authority to enter a

51 Information supplied by county clerk.

52 Ibid., part I, nos. 2, 2r.

${ }^{53}$ Computed from photostatic copies of assignment clerk's monthly report. 
judgment, a nonsuit, or a dismissal at the pre-trial hearing, on any cases so called. ${ }^{54}$ There are two pre-trial judges : one for chancery, one for law cases.

The purpose of the pre-trial hearing is to obtain settlement where possible, to dispose of preliminary motions, to frame issues, and in general to clear the way for the trial. The pre-trial judge frequently takes the attorneys for the opposing parties (and sometimes the clients) into chambers, where they discuss the nature of the issues, the number of witnesses to be called, the nature of documentary proof, the amount of relief which should be offered or accepted, and the like.

When preliminary questions have been determined and the issues are clear, the pre-trial judge dictates a "pre-trial statement" embodying the results reached. This document becomes a part of the record, and is binding upon the parties at the trial.

If at first conference the parties are unable or unwilling to clarify the issues so that a pre-trial statement can be drafted, the hearing is continued. Sometimes more than one continuance is necessary before the statement can be completed. A pre-trial statement is included as Appendix A.

Criminal cases are not handled by pre-trial hearing.

After pre-trial hearing, the case is never assigned to the judge who conducted the hearing. This policy is thought by Wayne County judges to account to some extent for the efficacy of the technique. In any but a multi-judge court, the pre-trial hearing presents the delicate problem of the extent to which counsel and judge can advantageously disclose their views upon matters which will ultimately be tried before that same judge. In Washtenaw County, which is a one-judge circuit adjoining the metropolitan district, the pre-trial conference is used in a less formal manner, and

54 Rules, op. cit., part II, nos. I, 4 . 
no written statement is made of the results of the hearing. The conference consists essentially of an oral discussion among counsel and judge with a view to disposing of such preliminary matters as will facilitate the course of the trial.

The judges who conduct the chancery pre-trial hearings and the law pre-trial hearings do not spend all their time in these capacities. In addition to this work, both judges carry their shares of regular trial assignments. For instance, in November of 1947, the assignment clerk's report shows that the chancery pre-trial judge (who happens to be the presiding judge of the court) disposed of four appeals, of ten criminal cases without trial, granted seventy divorces, discontinued eighty-two divorce cases, and denied one divorce, in addition to his work on the two specialized assignments. The law pre-trial judge (who happens to be the presiding judge of the state circuit judges) heard two motions, tried one criminal case and disposed of one criminal case without trial, tried a civil case, presided over a civil jury trial, granted four divorces and denied one divorce, in addition to his specialized assignments.

The compulsory use of the pre-trial conference in the Circuit Court of Wayne County is an outstanding practice of that court. According to the judicial council report for I 947, 77.2 I per cent of the cases ready for trial in Wayne County were finally disposed of at the pre-trial hearing. ${ }^{55}$ The annual average from I 935 to I 947 was $59.8 \mathrm{I}$ per cent.

Presiding miscellaneous judge. All ex parte orders, except habeas corpus writs and applications for injunctions in proceedings at law in the nature of a judgment creditors' bill, are issued by the judge presiding in the miscellaneous division. This judge hears the pro confesso divorce cases and determines miscellaneous motions. One judge acts in this capacity for a period of two weeks, at the end of which

55 Table XIII, and see pp. 215-216. 
time the presiding judge selects another judge to serve for the succeeding two weeks. Each miscellaneous presiding judge selects an alternate to perform the duties and exercise the powers of such judge should he be absent or unavailable. ${ }^{56}$

Judge acting as "one-man grand jury." During the period of observation, a Michigan statute was in force authorizing any judge to act as a "one-man grand jury" to investigate an alleged criminal offense, after the filing of a complaint. ${ }^{57}$ It had been held that a judge acting in this capacity was exercising a judicial function. ${ }^{58}$ Shortly after completion of the first draft of this survey, the statute was amended to require three judges, and to disqualify from other judicial work judges serving in this capacity. ${ }^{59}$ Under the rules obtaining at time of writing, which related to the earlier one-man statute, petitions were received by the presiding miscellaneous judge and presented by him to the full bench, which by majority vote decided whether to call a grand jury and if so, designated a judge to sit as grand juror. ${ }^{60}$

Judicial committees. Judicial committees are appointed from time to time as necessary or convenient. At present, the standing committees include ways and means (three judges); rules (three judges); Friend of the Court (three judges) ; probation (three judges); library (three judges) ; and legislation (three judges).

\section{Probate Court of Wayne County}

Presiding judge. A statute provides that in Wayne County, the presiding judge shall be chosen by his colleagues, or if no judge receives a majority vote, by gubernatorial

56 Rules, op. cit., part I, no. 5 , p. 4 .

57 767.3-767.4 Comp. Laws (1948); 28.943-28.944 Mich. Stats. Ann.

58 In re Slattery, 3 ro Mich. 458 (1945) (at 465 : "a judicial inquiry of the most ancient lineage").

59 P.A. r949, no. 3 Ir.

${ }^{60}$ Rules, op. cit., part I, no. 5 (c), p. 5 . 
appointment. The statute further provides that the presiding judge shall be selected within fifteen days after the commencement of each year, and shall act for the full calendar year. His statutory authority is restricted to "the power of nomination, appointment and removal of the several employes . . . and the general direction and control of the business of such court, including the division of the work between the judges. . . ."

The current organization is set forth in a memorandum issued October 19,1943 , by the presiding judge to the register and employees of the probate court, containing the following provisions:

"The judges are the final authority on all matters in the court-not only judicial, but also administrative and policymaking. . . Each judge's secretary, court clerk and court reporter . . are responsible only to the Judge they serve.

"The Probate Register is responsible directly to the Judges. .. He is held accountable for the efficient and smooth operation of every department of the court.

"All women employees . . . are under the direct supervision of the secretaries of the Probate Judges acting jointly.

"The foregoing schedule of organization applies only to the division of the Probate Court which is housed in the Wayne County Building, and does not include the Juvenile Division. The organization of the Juvenile Division is entirely under the jurisdiction of the Juvenile Judge."

The statutory control vested in the presiding judge of probate over personnel is largely dissipated in practice in Wayne County, first by the fact that the probate court personnel is under county civil service, and second by the agreed court policy that each judge controls his own staff. Reponsibility for calendar, docket, and case disposition ${ }^{61}$ 70r.6 Comp. Laws (1948);27.3178 (6) Mich. Stats. Ann. 
is placed upon the register. There are no standing committees, no regular judges' meetings, no local rules established by the probate bench as a whole. ${ }^{62}$ The juvenile judge does not participate in the selection of a presiding judge. ${ }^{63}$

Juvenile court judge. The judge of the juvenile court is selected by the entire probate bench. Only Wayne County has a full-time juvenile court judge. The present judge was first elected to the Wayne County Probate Court in 1935, and was at that time assigned to the juvenile division, where he has remained ever since. He has separate quarters in a different building from the probate court. The only contact between the juvenile court judge and the probate judges is the assignment of a probate judge to spend three half-days a week at the juvenile court, where he hears juvenile traffic cases in order to relieve the congested juvenile traffic docket.

Juvenile court functions and operations are not discussed by other members of the probate court, but have crystallized into a rigid form regarded by both divisions as separate and distinct from the problems of the probate court.

\section{Recorder's Court}

Presiding judge. The act which created the present recorder's court provides for a presiding judge to be chosen by the members of the court for not longer than three months. It further provides as follows :

"The presiding judge shall not be chosen to succeed himself. . . . The presiding judge shall exercise all the powers and privileges possessed by other members of the court, and in addition thereto shall be charged with the general supervision and superintendence of the work of the court. He shall preside at all meetings of the judges and shall assign the members of the court to the different divisions

${ }^{62}$ The Michigan court rules apply.

${ }^{63} \mathrm{He}$ did at one time, but the practice was discontinued several years prior to the field work for this study. But subsequently, in 1950, the juvenile court judge was acting as presiding judge of the entire probate bench. 
thereof and to particular kinds of work in such divisions in accordance with the rules. . . " 64

In practice, the office of presiding judge, like assignments to the misdemeanor division, rotates each month by court rule. ${ }^{65}$

Choice of presiding judge and of judges to try misdemeanor cases and to conduct examinations in the misdemeanor division is made not by the presiding judge, as contemplated by statute, but by the clerk, who prepares a schedule conforming to a regularly established sequence. This schedule is approved by a judges' meeting, after which it is published and posted under the signature of the presiding judge. The only deviation from the sequence occurs when the occasional unavailability of one or more of the judges-as by illness or grand jury duty-necessitates interruption of the pattern.

The real responsibility of the recorder's court presiding judge, currently, is the control of the felony docket. Each morning the day's felony cases are called, case by case, before the presiding judge. Those ready for trial are assigned by him to judges sitting in the felony division for the current month. As each case is assigned, the parties concerned depart from the presiding judge's courtroom and go to the courtroom of the judge to whom the case has been assigned. ${ }^{66}$

Arraignments on information are made by the presiding judge prior to the formal opening of his court, each day, for those cases requiring that step. Motions and miscellaneous matters relative to the progress of any felony case not already assigned for trial are determined by the presiding judge. All motions for adjournment, for nolle

${ }^{64} 725.2$ CoMp. Laws (1948); 27.3942 Mich. Stats. ANN. Later adopted by referendum by Detroit voters.

65 Statutes and Rules for the Recorder's Court (1938), rule 9, p. 105. ${ }^{66}$ Ibid., rule III. 
prosequi, and all guilty pleas must be heard by the presiding judge. A plea to a lesser included offense, if made before jeopardy attaches, must be sent back to the presiding judge for final disposition. Motions for new trials go before the presiding judge, as do motions for habeas corpus. ${ }^{67}$

The jury panel on duty for the month is under the charge of the presiding judge. ${ }^{68}$ Although he may, if time permits, try nonjury cases while serving as presiding judge, he is prohibited from trying jury cases while presiding. ${ }^{69}$ This, like the monthly rotation system, is designed to guard against corrupt prearrangement for trial of any case before a particular judge or juryman. ${ }^{70}$

The presiding judge receives petitions for one-man grand juries, but although the rules authorize him to designate a judge to act in this capacity, in practice judicial grand jurors are selected by the full bench. ${ }^{71}$ This rule has not been changed since the 1949 amendment, but in practice it is thought that few if any grand juries will be called.

By court rule, the presiding judge presides at judges' meetings, which are held regularly on the last Tuesday of the month, and when specially called..$^{72}$

The monthly rotation of this office is thought not only to guard against corrupt prearrangement for a certain judge or juryman, but also to guard against the establishment of cliques among the judges. In the view of the court staff, these advantages outweigh the development of specialized administrative skill and possible increased efficiency in docket handling which might result from a longer term for the presiding judge.

67 Ibid., rule 22, rule 9, rule 25; and see 725.12 Comp. Laws (r948); 27.3952 Mich. Stats. AnN., adopted by referendum.

68 RuLEs, op. cit., rule 33 .

69 Loc. cit.

${ }^{70}$ See infra, pp. 12I-122, for a description of the mechanical handling of the jury.

71 Rules, op. cit., rules 4 and 19.

${ }^{2}$ Ibid., rule 9. 
Executive judge. There is also an executive judge, elected for a year by a special judges' meeting. The court rules provide for wide supervisory power in this judge.$^{73}$ In actual practice, however, all serious decisions about the various departments of the court, their personnel, and their operation, are made by a full judges' meeting.

Recorder. The recorder of Detroit, historically, was a city officer who was a member of the common council and on occasion a vice-mayor. The title survives as a judge designated on the ballot as "recorder," who is selected as such by the voters, and whose salary from the city is $\$ 2,000$ more per year than that of the other judges. The recorder is a member of the Detroit Election Commission, and signs the official journals for all work done by the court except condemnation matters. Otherwise, the title is honorary. ${ }^{74}$

Judges assigned to specialized work in the misdemeanor division. A certain amount of judicial specialization is provided for by means of special dockets prepared each month by the clerk, approved by the judges in meeting, and posted and published. These dockets cover work to be done in the misdemeanor division of the court: They consist of (I) preliminary examinations, and (2) "early sessions," or misdemeanor cases to be tried. When the misdemeanor docket is large, as is the case more often than not, it is divided into two dockets differentiated by subject matter of cases : one judge is assigned to "early sessions-domestic,"

${ }^{73} \mathrm{Ibid}$, rule 1o, provides: "He shall supervise and have general control of the work of the Court, not otherwise controlled by statute or rule, nor vested in the Presiding Judge, and not within the individual discretion of the Judges. He shall make monthly reports to the bench of the work, of not only the court, but all its branches-Probation Department; Psychopathic Clinic; Office of the Clerk of the Court etc., for the preceding calendar month. He shall also make periodic recommendations to the Judges for their consideration."

In practice, no such reports are made by the executive judge, since reports are made directly from the various court departments to the judges' meeting.

74 O'HAGAN, op. cit., p. 6. 
to try domestic quarrels, neighborhood disputes, cases involving cruelty to children, and the like, while another judge handles "early sessions-general," involving misdemeanors committed by degenerate offenders-e.g., gambling, intoxication, prostitution, et cetera.

When the misdemeanor docket is light, a single judge handles it, but an attempt is made to segregate "domestic" from degenerate offenders. All of the misdemeanor judges, if they finish their special assignments on time, are supposed to send word to the presiding judge that they can take felony assignments for the rest of the day.

Judges acting as "one-man grand juries." Until the 1949 amendment ${ }^{75}$ the frequent use of judicial grand juries caused frequent shortages of judicial manpower at the recorder's court. During observation, three different judges at the court were engaged, each for a period of several months, in the capacity of grand jurors. The present requirement that three judges serve, together with the disqualification provision, will necessarily greatly reduce the number of judicial grand juries called. When called, such juries were approved by a full judges' meeting after petition to the presiding judge. The judges' meeting also selected one of their number to serve in the capacity of judicial grand juror.

Standing committees are: office of clerk, probation department, ways and means, rules and library, building, psychopathic clinic, and docket. Ordinarily there are three judges on each committee.

\section{Traffic and Ordinance Court}

The statute provides that "Said judges shall have the power to apportion the business of said court between themselves." In their default, the chief deputy clerk is authorized to distribute the work by assigning to the judges

${ }^{75}$ See supra p. 80 and p. 84 . 
cases which are ready for trial. Traffic judges, the statute states, "shall not participate in the organization or operation of the other division" of the court-i.e., recorder's court. $^{76}$

The two judges, in actual practice, take turns acting as presiding judge for a month. When they disagree, the clerk of the recorder's court, who is ex officio clerk of the traffic and ordinance court also, ${ }^{77}$ is asked to break the tie, by current custom.

Some of the work of the court is done without court action, through the work of referees, which is described elsewhere. ${ }^{78}$ Some is done through the receipt by mail of fines imposed for minor traffic violations.

\section{Court of Common Pleas}

There is no statutory provision governing judicial organization in this court.

By court rule, the judges elect one of their number to serve for six months as presiding judge. It is further provided that no judge after serving shall again be eligible until each of the others has served. The presiding judge designates a presiding judge pro tem to serve one month, "and thereafter the Presiding Judge Pro Tempore shall rotate monthly among the trial judges." "The presiding judge assigns the small criminal docket to each of the judges in monthly rotation, and presides at the monthly judges' meetings. He receives daily reports on hours spent and cases disposed of by each judge.

The presiding judge pro tem presides over the daily call which takes place each morning in the clearing room. The

76725.18 CoMp. Laws (1948); 27.3958 Mich. Stats. AnN.

77 725.x9 Comp. Laws (1948); 27.3959 Mrch. Stats. Ann.

78 Infra pp. Iо1-106.

79 Rules for the Common Pleas Court of the City of Detroit, effective May 15, 1946, rule 3 . 
judge stands at a counter at the side of the assignment clerk, who calls out the name of the judge who is to try each case assigned. Litigants report to the clearing room, and each litigant, when his case is assigned, goes to the courtroom of the trial judge. By rule, the presiding judge pro tem has charge of the conciliation docket, but in fact there have been no conciliation cases for several years. ${ }^{80}$

By present custom, there is also a daily presiding judge selected by the presiding judge. From observation, it is concluded that the special duty of the daily presiding judge, as such, is to be accessible throughout the entire business day.

Present disuse of specialized conciliation judge. In 1932, the common pleas judges provided by court rule for the establishment of a conciliation division ${ }^{81}$ and provided for the filing therein of claims not to exceed $\$ 35$. A specialized judge was assigned to this division in addition to his other duties.

In carrying out the work of the division, the judge noticed that workingmen who had accumulated several judgment debts had every wage payment garnished. There were large numbers of such debtors. As an experiment, the judge held conferences between the parties with the view of obtaining waivers of rights to garnish, on condition that defendants would make voluntary partial payments to the court, which impounded the file in order to insure that garnishments would cease. ${ }^{82}$

${ }^{80} \mathrm{Ibid}$, rule 35 . Any controversy amounting to $\$ 35$ or less may be voluntarily submitted by the parties to the court. During the depression, the conciliation division was very active. In $1947-1948$, the closest thing to conciliation is the provision whereby, under rule 36 , a garnishment may be stayed once only by a court order permitting partial payments to be made to the court. Partial payment matters are heard by any judge to whom they may be assigned.

81 Ibid., rule 35 .

82 "The Conciliation Division of Common Pleas Court," an address given to the Detroit Bar Association, January 9, 1935, by Judge Joseph A. Gillis, ms. p. $\mathbf{r}$. 
To provide leverage against a single unco-operative plaintiff among many holding judgments against the same defendant, a statute was enacted in 1933 providing that voluntary partial payments made to the clerk of the common pleas court under a court order would stay the issuance of any garnishments during the period in which the defendant was in compliance with such order to make payments. The conciliation judge was assigned to handle partial payment motions, which thus became part of the conciliation division.

Up to January I, I935, it was reported that 2I,595 claims had been entered in the division, that 55,320 payments had been made amounting to $\$ 108,069.06$, and that the average payment was $\$ 3.26$. Better than 90 per cent of these payments were made on judgments under the partial payment plan. In 1935 the judge estimated that about ro per cent of the work of the division consisted of handling the small claims under $\$ 35$. At that time there were approximately 5,600 open claims with payments being made by defendants to plaintiffs, through the court, out of their weekly or biweekly pay. Many people had six, eight, and ten judgments against them.

The judge found that it was necessary in many cases to protect defendants against illegal charges and interest made part of default judgments. "In checking one concern, it was found that in 47 cases they had charged an illegal \$2.0o locating charge, and in $4 \mathrm{I}$ other cases they had charged excessive interest. Many attorneys have failed to credit the docket, and also charged for garnishments that were not completed, or for a previous suit which had been dismissed for lack of progress." ${ }^{83}$

Established during the depression, the conciliation division handled II,II 5 partial payment cases as late as 1938 ,

${ }^{83}$ Ibid., pp. 1, 2. 
and 12,609 in $1939 .^{84}$ At that time the cases began to taper off as economic conditions eased. There were also changes in the personnel of the court.

In 1946 , a total of 3,168 partial payment orders were entered. In January of $1948,3,679$ such cases were started, and 2,064 orders for partial payment were vacated for a missed payment. ${ }^{85}$

The court staff advises that there have been no true conciliation cases (claims under \$35) for several years, and that partial payment cases are assigned to each of the judges in turn. Under present practice, the granting of a motion for partial payment does not stay a pending garnishment, and only one partial payment order is made for each defendant, which is suspended by a single default in payment. $^{86}$

In short, there is currently no conciliation division at the court. While the shift in the economic cycle accounts in part for the decline in the operation of this specialized division, it is clear that the collapse of the division and the departure from the court of the judicial personnel which was interested in the conciliation division are not unrelated.

The contrast in the conciliation and partial payment practices in 1935 and in 1946 constitutes a striking example of the variation in use of specialized judges which results from a shift in public pressure and in judicial personnel, even where the machinery of statute and court rule remains unaltered.

\section{Outlying courts in the district}

Experiments with questionnaires and letters led to the decision that in fairness to the courts and to this study, no information other than simple quantitative statements (such

${ }^{84}$ Information supplied by clerk of the common pleas court.

85 Ibid.

${ }^{86}$ Information supplied by various judges in consultation. 
as number of judges, statutory jurisdiction, and the like) would be included unless rounded out by observation and discussion with judges and court executives. Field work was concentrated in Detroit because the courts sitting there display essential differences from nonmetropolitan courts. While, therefore, some material has been included for outlying courts, no analysis of the organization of such courts has been made. In subsequent pages, the classification "outlying courts" will be omitted without further comment.

c. Use of Specialized Judges and Administrative Judges in Detroit

All the multi-judge courts have some provision for an administrative, or presiding, judge, to control the flow and distribution of business. This machinery has been used to the fullest extent in the Circuit Court of Wayne County, and the operation of this court exhibits the active exercise of the authority of the presiding judge in all departments of the court.

In the recorder's court, also, the presiding judge exercises extensive administrative powers, and elaborate precautions are taken to prevent the continuous exercise of this responsibility by the same judge for more than a short period of time. These functions of the presiding judge are of vital significance to the operations of the court.

In contrast, the other courts make far less use of their presiding judges.

There is obviously a certain relationship between the extent of the administrative authority exercised by the judge and the number of judges on the bench: The circuit court and recorder's court, with eighteen and ten judges respectively, have more judges than the other courts, and they are the courts which make the most effective use of a presiding judge. 
On the other hand, the court of common pleas has a large judicial personnel of nine judges, and yet there has been only a slight development of real docket control or of personnel administration by the presiding judge. Apparently other factors besides the size of the judicial staff exercise an influence upon the problem under discussion, such as the size and character of the case load, the amount of public pressure for increased efficiency, and the personal interest of the judges in administrative organization.

In the recorder's court, which is of course a specialized court itself, being exclusively a criminal tribunal, ${ }^{87}$ the judges are alert to the dangers of overspecialization, against which they constantly guard by the monthly rotation system, and by referring all matters of importance to a full judges' meeting.

The statute creating the present recorder's court gave the judges wide latitude to establish specialized divisions: ". . . the members of the court or a majority thereof may establish and maintain specialized branches or divisions. ... Insofar as possible, the business of the court shall be so arranged that minors shall be kept separate and apart from other offenders." ${ }_{88}$ In practice, the cases affecting minors are not in any way differentiated from other cases. The only observable progress toward the development of specialized divisions is the creation of the misdemeanor dockets for the purpose of separating the degenerate elements from the domestic disputes.

Specialized divisions have a tendency to develop into separate courts. The traffic and ordinance court is an excellent example of the assumption, by what was originally a specialized division of recorder's court, of independent existence as a separate court. Another example of the same

87 With the trifling exception of the city condemnation cases.

${ }^{88} 725.3$ Comp. Laws (1948); 27.3943 Mich. Stats. Ann. 
tendency of specialized divisions or judges to pull away from the parent court is the juvenile court. The completeness with which the juvenile court is divorced from the probate court is a disadvantage to both courts.

Section 6. Extent of Judicial Services Rendered

a. Hours of Service of Judges

Circuit Court of Wayne County judges

Court is held from Io:00 A.M. until I $2: 30$ P.M. and from 2:Oo P.M. until 4:30 P.M. each weekday except Saturday. On Saturday, the presiding miscellaneous division judge and the judge hearing alimony motions hold single sessions of court from 10:00 A.M. until I 2:00 P.M. In July and August court hours are subject to change by court order. ${ }^{89}$

Attendance of judges is taken twice daily by the assignment clerk personally, and the results noted down on a form prepared for the purpose. Once a month, the total attendance and work done by each of the eighteen judges is tallied and reported to the presiding judge. Photostated copies of this report, which includes the individual record of each judge, identified by name, are distributed by the presiding judge at the monthly meeting of judges. In this way each of the judges is fully informed at all times as to his comparative status in courtroom days and cases disposed of..$^{90}$

During the calendar year 1947, the eighteen judges of the Circuit Court of Wayne County worked, respectively,

89 Rules of the Circuit Court for the Third Judicial Circuit of Michigan (Wayne County), revised to April 1, 1948, part I, no. r. Under the I94I rules, court opened at 9:30 A.M. on weekdays and the Saturday session closed at 12:30 P.M.

${ }^{90}$ Each page covers one week. The names of the judges appear at the left of the page, running from top to bottom. Across the top of the page appear the days of the week, and then the following classifications: "Law; Chan.; Misc.; Crim.; App.; Pres.; Chan. Pre-trial; Law Pre-trial; Days." 
the following number of total full courtroom days: 223,

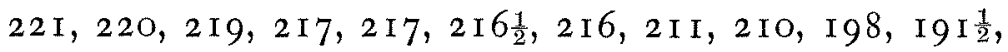
I $90,174,173,162,95,25 .{ }^{91}$ One judge died during the year, another suffered serious illness. Average: I 75.5 days; median: 2 Io days.

\section{Recorder's Court judges}

The court operates on a six-day week. The presiding judge and the judges trying misdemeanor cases, however, are the only ones to hold court on Saturdays. It is estimated by the clerk that each judge is in court on Saturdays for about two months in a calendar year. A statute sets the court hours as from 9:30 A.M. to I $2: 30$ P.M. each secular day, from 2:00 P.M. to 4:00 P.M. each secular day, and permits the court to fix additional hours as deemed necessary. ${ }^{92}$

The hours are announced each month by the presiding judge in the schedule posted to display the assignments of the various judges. The presiding judge and the judges holding misdemeanor trials-i.e., "early sessions"-formally open court at 9:00 A.M., although judges on these assignments actually begin their work before court opens. ${ }^{93}$ When a jury is out, or when he is on grand jury duty, or for some other reason, a judge may stay after court hours. On the other hand, a judge on examinations or early sessions may leave when his portion of the work of the misdemeanor division has been finished, instead of sending to the presiding judge for a felony assignment to round out the day.

91. Information supplied by the assignment clerk.

92 725.5 Comp. Laws (1948); 27.3945 Mich. Stats. Ann.

93 The judges on early sessions go over the day's arrest tickets with a police officer, and sign warrants for those whom the judge decides to hold for court action. The presiding judge goes over the current group of arraignments each day with the prosecutor, and makes arraignments on information, prior to actually taking the bench. 
During observation, one judge stayed until 6:30 P.M. for a jury to come in, another conducted examinations until 2:0O P.M. without a break and then left for the day, still another (on grand jury duty) was reported to have worked until I I : 30 P.M. one night. "Early sessions" usually is completed by I I :30 A.M., with one midmorning adjournment of ten or fifteen minutes. Occasionally on a heavy day, such as Monday, the sessions will run until I :oo P.M. or I :3O P.M. During October, I948, a check of misdemeanors from the court sheets shows that the two judges on early sessions that month took some felony trials during a majority of the working days in the month, in addition to the misdemeanor assignment.

The court sheet, comprising a daily report of all work done and money collected by each judge, is the only record made by the recorder's court of the activity of its judges. It serves, however, as an attendance record. Each day this court sheet is turned in to the clerk of the court by the courtroom clerk of each judge. During the calendar year I 947 , the number of courtroom days spent by the several recorder's court judges were respectively as follows: 274, $240,236,234,233,23 \mathrm{I}, 223,22 \mathrm{r}, 207$, 186. Average : 228.5 ; median: 232 . The court sheets do not differentiate between full days and partial days. ${ }^{94}$

\section{Common Pleas judges}

By court rule, sessions are held from $10: 00$ A.M. to $12: 30$ P.M., and from 2:00 P.M. until 4:00 P.M. daily, except Saturday..$^{95}$ Each judge reports his daily and hourly attendance to the clerk of the court, who tabulates the information for inclusion in the presiding judge's annual report to

94 Information furnished by the clerk.

95 Rules for the Common Pleas Court of the City of Detroit, effective May 15, 1946, rule 2. 
the Common Council of the city of Detroit. During the year 1947 , the several judges reported their working days and hours as follows-days: $254,244,244,239,234,228$, $216,180,73$; hours: $1235,1500.5,1492,1432.5,1492$, I 314.5, I $440,1045.5,434 .{ }^{96}$ Average : 217 days; median : 234 days.

Judges of Traffic and Ordinance Court, Probate Court, and Juvenile Court

The clerks of these courts advised that no records are kept of attendance as such, and that it would not be practical to compute the information from other records.

\section{Comment on hours of service}

There were about $25 \mathrm{I}$ working court days during 1947 , Saturdays omitted. In the three courts for which data regarding the judges' working days were available, each judge worked on an average about 207 days.

\section{b. Case Load per Judge}

On a court-by-court basis, the case load of courts sitting in Detroit is much greater than anywhere else in Michigan. The growth of multi-judge courts in the most densely populated part of the metropolitan district raises a doublebarreled question: Does each judge in the metropolis handle a heavier yearly case load than a judge in a similar outlying or upstate court, and how well does he handle it?

\section{Circuit courts}

There are forty circuits in the state of Michigan. During I 947 , the average case load per judge was 786 cases dis${ }^{96}$ Annual report of presiding judge to Common Council, January ro, I948. 
posed of: the lowest was $146^{97}$ and the highest $1,570 . .^{98}$ Eight circuits had a case load of over I, ooo cases per judge. Among these is Wayne County, the eighteen judges of which disposed of 1,255 cases per judge during $1947 .^{99}$ In Macomb County, the case load per judge was 468 cases disposed of; in Oakland County, I, I6 64 cases per judge.

It appears, therefore, that of the circuit judges in 1947 , the Detroit judges each disposed of a case load which was heavy, but not as heavy as that disposed of by some judges outside the metropolitan district.

\section{Courts sitting in Detroit}

As a general indication of the amount of work accomplished in a year by judges sitting in Detroit, the following table sets forth the case load per judge of each of the courts sitting in Detroit. It is not the intention to compare essentially dissimilar case loads, but to point out the number of different matters which, in a year, engage the attention of each of the various judges.

By way of comparison, the total case load for 1947 was 375 in the justice court of Garden City, and in the justice court of Sylvan Lake the annual case load runs between eighty and one hundred. ${ }^{100}$ Both are cities on the fringe of the metropolitan area, and each has one justice of the peace.

97 Eighteenth Annual Report of the Judicial Council of Michigan: JUdicial Statistics for THE YeAR I947 (September, 1948), pp. 13-I4. The lowest was the thirty-second circuit, comprising Gogebic and Ontonagon Counties, a rural area.

98 Ibid. Fourteenth circuit: Muskegon County, not a metropolitan area. Likewise, in Washtenaw County, a one-judge circuit (twenty-two) in a nonmetropolitan area adjoining the Detroit metropolitan district, the case load was $\mathbf{1 , 2 7 5}$.

99 Ibid. Wayne County is the third circuit.

100 As reported by letter by the justices of these cities. For the case loads of justices in nonmetropolitan areas, see Sunderland, op. cit., pp. 7x-73, showing that township justices' loads run as small as eighteen cases per year per township. 


\section{TABLE $X V I^{1}$}

Case Load per Judge, of Courts Sitting in Detroit (i947)

Court

Cases per

Circuit judge

Probate

administrative cases started during year........ 2,160

mental cases disposed of during year.......... 539

Juvenile

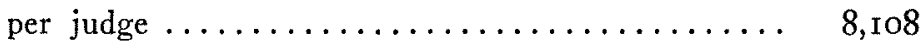

per judicial officer (counting referees) ........ I,35I

Recorder's

per judge on bench.................. 2,490

per judge actually sitting.............. 2,900

Traffic and ordinance

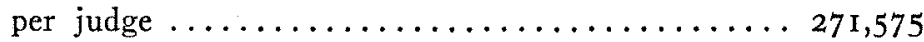

per judicial officer (counting referees) ........ 77,593

Common pleas ..................... 4,496

1 "Administrative cases" is a term used by the register of the probate court to describe all cases requiring the continuous supervision of the court, and thus includes estates and trusts which require administration. Information concerning the number of cases disposed of was not obtainable from the probate court, and the register points out that the number of administrative matters begun is equally meaningful in this connection. As to the number of matters under continuous supervision which came on for hearings during the year, no information was obtainable; if it were, the figure shown would no doubt be higher.

See infra pp. Ioo-106 for a discussion of referees and other quasi-judicial officers. The work of the juvenile court referees is described at pp. I02-105.

The clerk at recorder's court suggests the differentiation between load of judges sitting and those on the bench, and supplies it for his court. This figure includes both cases in the misdemeanor division and the felony division.

Many of the traffic and ordinance cases were no doubt summarily settled by the payment of fines and without an actual hearing. Information as to the number so settled was not obtainable.

Most of the court of common pleas cases are defaulted. See pp. r33-134; 215-216.

For a discussion of machinery for handling dockets, see infra pp. 194-270.

\section{Comment on case load per judge}

Although it cannot be demonstrated that the general case load per judge is heavier in the metropolis than elsewhere, in general the work of any judge sitting in Detroit 
is heavy enough to account for the full time and energies of the judicial personnel in the city.

The case load in a metropolis may be different in char* acter than elsewhere, because of the characteristics of metropolitan life and the disproportionate incidence of certain kinds of cases.

In disposing of his case load, the judge sitting in a metropolis is under pressure to make timely disposition of a certain number of cases, in order that the load of the entire court may keep abreast of its docket. At the same time, the judge sitting in a metropolis has less personal knowledge concerning any one case, and less time to obtain more knowledge, than elsewhere. ${ }^{101} \mathrm{It}$ is apprehended, therefore, that because of (a), the case load per court, and (b), the pressure on each judge to increase the disposition per judge, there is, in a metropolis, a problem confronting each judge which is dissimilar to that of judges outside the metropolis-namely, the problem of responding to the pressure from an administrative or executive judge to dispose of a certain number of cases, while at the same time maintaining sound standards of quality in disposing of each case.

This problem is met, as will be shown, by supplementing the judicial knowledge and control of each judge in many

101 A circuit judge who has had experience in rural and in metropolitan areas points out that in Wayne County it is impractical to require a trial brief because of the pressure to keep up with the docket. Yet, he notes, in almost no case in Wayne County (except for those made causes célebres by the newspapers) has the judge any knowledge at all of the matter until counsel presents it in the courtroom. This is not the case in a one-judge nonmetropolitan court, where the argument of preliminary motions, the regular sounding of the trial docket each term, and the general conversation of members of the local bar will have familiarized the judge, before actual trial, with the bare bones of the matter.

This difference does not necessarily impair quality; it can be maintained that by imposing objectivity upon the metropolitan judge, it protects quality. The point here is that a different problem of maintaining quality is placed upon the judge. 
different ways: by increasing the judicial staff by means of quasi-judicial personnel, ${ }^{102}$ by establishing large administrative agencies to investigate and supervise for the judge, ${ }^{103}$ and by attempting to co-operate with agencies outside the judicial process which already have knowledge and control of the parties to the case. ${ }^{104}$

\section{Section 7. Quasi-Judicial Personnel}

\section{a. Circuit Court Commissioners}

In exercising the jurisdiction hitherto described, nonmetropolitan commissioners work in their own law offices, and records of their operations are kept as part of the circuit court records. ${ }^{105}$ In certain cities, justices of the peace may sometimes act as circuit court commissioners. ${ }^{106}$

In Wayne County, the commissioners have a clerk of their own, with four assistants, who maintains a central office for the keeping of records in the commissioners' landlord-tenant cases. In addition, each of the four commissioners has his own courtroom and his own courtroom staff consisting of stenographer, clerk, and deputy sheriff. During I 947, I 7,300 landlord-tenant cases were started before the Circuit Court Commissioners of Wayne County. ${ }^{107}$

Although the presiding judge of the court requires monthly reports on work done by the commissioners in special chancery matters referred by the presiding judge of the circuit court, yet as to matters within their independent jurisdiction they do not report, their records are separate, and a matter which goes up to the circuit court after action by the commissioner is officially described, both by the

${ }^{102}$ Infra pp. 100-106.

${ }^{103}$ Infra pp. 149-r 92.

104 Infra pp. 233-246; 249-267.

105 Supra pp. 33-35.

106730.13 Comp. Laws (1948); 27.3763 Mich. Stats. Ann.

${ }^{10}$ Information supplied by the clerk of the Wayne County Circuit Court Commissioners. 
commissioners' clerk and by the county clerk, as an appeal. There were 167 of these "appeals" during $1947 .{ }^{108}$ To the extent noted, these quasi-judicial officers appear to be in the initial stage of development toward a separate identity from that of the parent court. ${ }^{100}$

\section{b. Friend of the Court}

A recent statute has given to another officer, the Friend of the Court, authority to act as referee by taking testimony and making reports to the circuit judge in contested custody and property matters relative to a pending divorce action. ${ }^{110}$ These actions, therefore, are not referred to the commissioners at present.

\section{c. Referees}

Another device is noted in recorder's, juvenile, traffic, and probate court which augments judicial man power without the creation of additional judges. This is the creation of referees who relieve the judges of sizeable portions of their trial load, and who actually, though not theoretically, perform judicial functions.

\section{In the Traffic and Ordinance Court}

The statute regulating the court provides:

"The said judges . . shall have authority to appoint I or more referees, who shall have authority to administer oaths, examine witnesses and make reports and recommendations to the judges . . . in such misdemeanor cases under state laws or municipal ordinances as may be referred to them. . . The compensation . . and the amount of bond . . . shall be fixed by the judges. . . . Such referee/

108 Information supplied by the county clerk.

109 Compare pp. 37-40; 46-47.

$110552.25 \mathrm{I}-552.253$ Comp. Laws (1948); 25.17 I-25.173 Mich. Stats. AnN. 
or referees ... shall hold office at the will thereof [of the judges ]."111

There are at present five such referees, of whom four are attorneys. Each of them has his own courtroom and court attendants, and each has a docket of cases consisting of traffic or nontraffic ordinance or misdemeanor matters. Referees do not hear homicide or "drunk driving" cases, nor do they hear any cases in which warrants have been issued. ${ }^{112}$

Information was not obtainable as to the number of cases handled by referees in 1947 , but it has been estimated that in 1942 , they handled at least 125,000 cases. ${ }^{113}$ The referees have no court stenographers-i.e., no record is made of the evidence on which the decision is made. The decision itself is reduced to a journal entry and is signed by the presiding judge. If a defendant protests the referee's decision and demands a trial before one of the judges, the matter is tried $a b$ initio. Information was unobtainable as to the number of such protests; it is said to be very small. Unless protest is made, the referee's decision stands as a final adjudication.

\section{In the Juvenile Court}

The statute regulating the court authorizes probation officers designated by the court to "act as referee in taking the testimony of witnesses and hearing the statements of parties upon the hearing of petitions... where there is no objection by parties in interest." The statute further provides that the referee "shall in all cases so referred ... make a written signed report to the judge . . containing

111 725.19 Comp. Laws (1948); 27.3959 Mich. Stats. Ann.

112 By court policy. Information supplied by chief deputy clerk of the traffic and ordinance court.

113 O'HAGAN, op. cit., p. 20. 
a summary of the testimony taken and a recommendation for the court's findings and disposition of such matters."114

There are at present six employees at the juvenile court who act in various ways as quasi-judicial personnel. All are described as referees by the court staff. Since their respective authority and functions differ one from another, they are separately described as follows:

( I) Official boys' referee: This man is designated on a permanent basis by the court to act as referee in all hearings on official petitions relative to delinquent boys, except those petitions which are heard by the judge himself. This official, a former boys' department probation officer with considerable experience as a court executive, is the only person currently devoting full time to quasi-judicial duties.

(2) Director of the boys' department: This man is also the chief probation officer of the department, the work of which is concerned with delinquent boys. $\mathrm{He}$ acts as referee in "unofficial" cases arising in his department. An "unofficial" case, as the term is used by the juvenile court staff, is one which is settled without the filing of an official petition and without a hearing. All cases originate, each in its appropriate department, as "unofficial" cases, and become official cases only when and if the head of the department, unable to solve the child's problem otherwise, sends the file to the register for the drafting of an official petition.

Thus an "unofficial" case is not a case which is beyond the authority of the court, for the statute specifically contemplates the making of a "preliminary inquiry" in each case to ascertain whether the problem can be solved without the filing of an official petition. ${ }^{115}$ The head of the boys' department, then, when he acts as "referee" in an "unofficial" case, is in legal theory conducting a preliminary

1147 I2 A. Io Comp. LaWs (1948); 27.3178 (58r) Mich. Stats. Ann.

1157 12 A. r 1 Comp. Laws (1948); 27.3178 (582) Mrch. Stats. Ann. 
inquiry, and is actually giving advice after consultation with the child, the department workers, and other interested parties, which advice, if followed, will result in successful termination of the case before it reaches the "official" stage.

(3) Director of the girls' department: This official is also chief probation officer of the department. She acts as referee in official and in "unofficial" cases arising within her department, which concerns itself with delinquent girls from seven to seventeen. When acting thus with respect to an official case, she is acting as a referee as contemplated by the statute. When acting upon "unofficial" cases, she is successfully terminating the preliminary inquiry without the filing of an official petition.

(4) The register: This official is not a probation officer, but is authorized by statute to perform any acts authorized by the judge short of judicial duties. He acts as referee in minor traffic cases, and in other official cases as designated by the judge when the dockets are congested.

(5) The chief clerk: This official is not a probation officer. He acts as referee in minor traffic cases. ${ }^{116}$

Practice in proceedings before referees. No serious traffic cases, such as homicide or "drunk driving" cases, are heard other than by the judge himself. All cases involving the taking away of a child from its parents are heard by the judge personally. By general court policy, no referee conducts a case where the parties indicate by word or manner any dissatisfaction with the referee. Such hearings are terminated and the case referred to the judge.

In minor traffic cases, no record is made at the hearing before the referee. In these cases, the court order is prepared by the referee and the file containing the order is sent to the judge for signature. In cases other than traffic cases,

${ }^{116} 712$ A.7 Comp. Laws (1948); 27.3178 (579) Mich. Stats. ANN. 
each case file contains a case history, a summary, and recommendations made from time to time by the department probation officers who investigate the case and by the department executive who decides on various steps as the case develops. When a case is terminated unofficially by a "referee," there is no necessity for making the report and recommendations, since no court order is actually involved. Hearings on official cases involving delinquency, dependency, or neglect, when heard by a referee, are attended by a stenographer who takes notes on the testimony, from which a transcript can be later made up if necessary. The referee prepares a court order for the judge to sign, and the entire file is transmitted to the judge, who ordinarily signs it as a matter of course.

The use of each department head as referee for cases in his own department is part of a consistent court policy. Children referred to the court are first seen by a department worker, and every attempt is made to solve the problem within the department. This enables the worker to establish and maintain a good relationship with the child.

\section{In the Probate Court}

The regulating statute permits the appointment of referees by the court in contested claims matters, and contemplates the making of a court order either approving or disapproving the recommendation of the referee. Similar power has been held, in Michigan, to be judicial in nature. ${ }^{117}$ In Wayne County, all claims are set down for hearing by a deputy clerk. If any is contested, the judge to whom the estate has been assigned appoints a referee. No record is

117 Under an earlier probate code, commissioners were appointed for this purpose. It was held that their power was judicial, and that the court itself had no power to exercise jurisdiction over the claim, except to register final approval or disapproval, once a commissioner had been appointed. Clark v. Davis, 32 Mich. 54 ( 1875 ). 
kept of the number of such appointments, and therefore no conclusions can be drawn as to the extent of the use of referees in Wayne County.

\section{In the Recorder's Court}

Condemnation cases are left by court rule for the presiding judge, who signs journal entries in these matters. ${ }^{118}$ Currently, a separate room is set apart for the conduct of hearings on condemnations, which are presided over by a deputy clerk who acts as an unofficial referee. When counsel or parties fail to agree or a question arises, the presiding judge is sent for.

Section 8. Total Personnel Exercising Judicial Functions in Detroit Metropolitan District

The geographical disposition of the various kinds of judicial and quasi-judicial personnel is set forth in the following table:

\section{TABLE XVII}

Number and Status of Total Judicial Personnel in the Detroit Metropolitan District (1948)

\begin{tabular}{|c|c|c|c|c|c|}
\hline & $\begin{array}{l}\text { Judges } \\
\text { sitting in }\end{array}$ & $\begin{array}{l}\text { In Wayne } \\
\text { County } \\
\text { outside }\end{array}$ & $\underset{\text { Macomb }}{\text { In }}$ & $\begin{array}{l}\text { In } \\
\text { Oakland }\end{array}$ & \\
\hline Cype & Detroit & Detroit & County & County & Total \\
\hline ar judges & . 45 & $6_{3}$ & 24 & 50 & 182 \\
\hline onal judges & . & 3 & $\mathbf{I}$ & 3 & 7 \\
\hline judicial judges. & 17 & $\cdots$ & 2 & 2 & 2 I \\
\hline & - & $\bar{c}$ & 一 & 一 & \\
\hline otal & .62 & 66 & 27 & 55 & 210 \\
\hline
\end{tabular}

"Occasional judges" include the part-time associates and alternate judges used in some outlying courts as described above. ${ }^{119}$ The "quasi-judicial" figure does not include ref-

118 Statutes and RULes for the Recorder's Court (1938) rule 9.

119 Supra pp. 72-73. 
ORGANIZATION : JUDICIAL PERSONNEL IO7 erees occasionally appointed by the probate courts in the area, since we have no data on the number of occasions such personnel have been appointed nor on the amount of time spent by them.

Note the way in which occasional personnel is confined to the area outside Detroit, and the way in which quasijudicial personnel has developed in the city. Table XVII should be compared with Table I (courts in the Detroit metropolitan district), and Table XV (multi-judge courts). It will be recalled that Table XV shows forty-four regular judges sitting in multi-judge courts in Detroit; the juvenile judge, regarded as a separate one-judge tribunal, should be added to obtain the total number of judges sitting in Detroit (forty-five). 
Chapter IV

\title{
Organization of Courts in the Detroit Metro- politan District: Attorneys and Juries
}

\author{
Section i. Attorneys
}

a. Prosecutor and Defense Counsel in Misdemeanor Cases $\mathrm{A}^{\mathrm{N}}$ ASSISTANT county prosecutor is assigned to the courtroom of each judge who is trying misdemeanor cases in the recorder's court, but his services are not often used. The judge questions the defendant and conducts the trial. When the judge asks for information or advice, he turns more often to one of the probation officers assigned to his courtroom than to the prosecutor.

Any misdemeanant who requests assigned counsel is provided with an attorney at public expense. ${ }^{1}$ This happens only a few times a year, the clerk estimates. Misdemeanants are not informed of their right to counsel, and court personnel agree with the writer's conclusion that at least 80 per cent of the misdemeanors are tried without defense counsel. ${ }^{2}$ Of 20,428 misdemeanors disposed of in 1947,83 per cent of the defendants were convicted. ${ }^{3}$

\section{b. Prosecutor and Defense Counsel in Felony Cases}

These cases are presented for the people by assistant county prosecutors. Certain members of the prosecutor's staff work exclusively on drafting; others screen out cases

${ }^{1} 775.16$ Comp. Laws (1948);28.854 Mich. Stats. Ann.

2 Courtroom observation covered more than six weeks in the recorder's court.

3 Annual Report of the Clerk of the Court (1947), p. 4. 
which are not to be prosecuted. ${ }^{4}$ General trial policy is to assign an assistant prosecuting attorney to each courtroom, and to interchange the personnel frequently. While on courtroom assignment, a man spends one month in the office, the next in the courtroom. In recorder's court, an assistant prosecutor is assigned to follow the presiding judge, and this assignment is relatively permanent. ${ }^{5}$

Certain cases are classified as "hot": murder, sex cases, and any prosecution instituted after grand jury action. Special assistants are assigned to all such cases, and some pre-court investigation and preparation takes place under the direction of the prosecutor who is to try the cases. All the other cases-the great majority-are tried "cold"that is, an assistant prosecutor who tries the case sees the file for the first time when he opens it in the courtroom to interrogate his first witness.

\section{Assigned defense counsel}

Defendant's constitutional $^{6}$ and statutory ${ }^{7}$ right to defense counsel is less than it seems from the constitution and statutes. A person accused of a felony in Michigan is not entitled to counsel as of right to advise him relative to his plea, nor at examination, nor after a plea of guilty. ${ }^{8} \mathrm{~A}$

4 In $1946,38,895$ offenses were known to the Detroit police; there were 29,192 prosecutions and 24,359 convictions during the same year. EIGHTYFirst Annual Report, Detroir Police Department (Detroit, Michigan: 1946), tables III, III-A, pp. I5-I7.

${ }_{5}$ The presiding judgeship rotates every month, but the same prosecutor continues from month to month as presiding judge's prosecutor.

- Constitution of Michigan (I908), art. II, § r9: "In every criminal prosecution, the accused shall have the right to ... the assistance of counsel for his defense. ..."

${ }^{7} 763.1$ Comp. Laws (1948); 28.854 Mich. Stats. AnN. "On the trial of every... criminal accusation, the party accused shall be allowed to be heard by counsel. ..."

${ }^{8}$ People v. Williams, 225 Mich. I33 (r923); People v. Harris, 266 Mich. 317 (1934). In People v. Harris, 270 Mich. 124 (1935), the statute was said not to be applicable where a fifteen-year-old boy pleaded guilty to a charge of murder in the first degree, where the court before accepting a plea ex- 
statute provides that the presiding judge may provide counsel at public expense for an accused who is without an attorney; the statute is permissive only-it cannot be invoked until after plea and not at all under a plea of guilty. ${ }^{\circ}$ Both the Circuit Court of Wayne County and the recorder's court provide by court rule for amounts to be allowed counsel assigned to defend indigent persons..$^{10}$ In 1947 , the recorder's court issued $95 \mathrm{I}$ vouchers for assigned counsel, which totaled $\$ 55,385$, an average fee of $\$ 59.39 .{ }^{11}$ The clerk advises that the use of assigned counsel for misdemeanants is so rare that this total approximates the total use of assigned counsel for both felony and misdemeanor divisions.

In the Circuit Court of Wayne County, 500 felony cases were disposed of during I947 (356 without trial, I44 tried). ${ }^{12}$ Twenty-five counsel were assigned by the presiding judge during the year, at a total cost of $\$ 1,895$, or an average of $\$ 75.80 . .^{13}$ In practice, in the circuit court, defense counsel are assigned before the plea.

amined witnesses and the defendant, notwithstanding defendant was not advised or represented by counsel before or after pleading. But see DeMeerleer v. People of State of Michigan, 67 Sup. Ct. 596 (r948) (reversing 3 r3 Mich. 548). And see, casting doubt on the DeMeerleer case, the Bute v. Illinois decision, 333 U.S. 640 (1948).

As to the importance of being advised at the examination, in $1948,2,422$ defendants waived examination in recorder's court, $x, 056$ were bound over for trial, and 276 were dismissed at examination. Information furnished by the clerk of the recorder's court.

9 See the Williams case, supra n. 8.

${ }^{10}$ Circuit court rule 26, part I; recorder's court rule $3 \mathrm{x}$. Both provide a $\$ 100$ maximum fee for murder, rape, robbery armed, and assault with intent to rob being armed, and a maximum of $\$ 50$ in all other cases.

In recorder's court, a higher fee may be obtained, after petition by counsel, upon agreement of the judges; in the Circuit Court of Wayne County, if the trial judge finds the stated fee inadequate, he may refer the matter to the judges, with recommendation, for their decision.

11 Annual Report of the Clerk of the Recorder's Court (i947). In 1948: 1,040 vouchers, total of $\$ 62,330$ (average: $\$ 50.93$ ).

12 Eighteenth Annual Report of the Judicial Council of Michigan, op. cit., table II, p. 39.

${ }^{13}$ Information supplied by presiding judge of the circuit court. 
Thus, counsel were assigned in 5 per cent of the criminal cases disposed of in circuit court in 1947 ; in 3.8 per cent of the cases at recorder's court.

\section{Defense counsel in felony cases in Recorder's Court}

In order to determine whether any serious felony cases were reaching final disposition without defense counsel, a "spot check" was made, on February I 9, I948, from current felony files in the office of the clerk of the recorder's court. ${ }^{14}$ It covered fifty-three cases started after October $3^{1}$, I947, and thirty-four started after July I, 1947, all of which had gone to final disposition before the check was made. So far as the files showed, twenty-eight of the defendants in these cases were without counsel. Of these, four cases were dismissed for lack of prosecution, four cases were dismissed for lack of complaining witness, and seven were nolle prosequi'd. ${ }^{15}$

Nine of the unrepresented defendants pleaded guilty: one to malicious destruction of property, two to breaking and entering, one to grand larceny, three to minor larcenies, and two to sex charges. One unrepresented defendant was found guilty by a jury of giving a check without sufficient bank funds to pay it, and one was committed by a sanity commission to the state institution for the criminally insane. He was held on an indecent liberties charge.

In a cross check conducted several months later, on September 30, I948, fifty more finished felony cases in the recorder's court were examined, and six unrepresented

14 The court statistician who helped this writer with the check expressed doubt as to the results, pointing out the possibility that in some of the files, both the entry of appearance and the courtroom clerk's notation on the file cover might be missing. Where no notation was found on the cover, we looked for the entry of appearance.

15 Of 4,474 felony cases disposed of in 1947 at recorder's court, 348 were dismissed on motion of prosecutor or defense attorney, 774 were nolle $d$, $\mathbf{I}, 74 \mathrm{I}$ were disposed of on guilty pleas, $2 \mathrm{x} 9$ were found guilty by a jury, 32 were committed to Ionia as insane. 
defendants were found, of whom two were committed as insane by sanity commissions, one pleaded guilty to aggravated assault, and one, after waiving a jury, was found guilty by the court of felonious assault.

It is clear, therefore, that despite the statutory right to assigned counsel, and despite court policy of enforcing that right, some serious felony cases in recorder's court reach final disposition after trial without defense counsel.

In the above-mentioned group of eighty-seven files examined February 19, I948, fourteen of the fifty-nine defendants having attorneys were found to be represented by counsel belonging to a group of habitués of the recorder's court building who know the tricks of criminal practice and pay the least possible attention to standards of ethical conduct. On the other hand, six of the defendants were represented by attorneys regarded by the court personnel as "regulars"- that is, attorneys often seen at the court, but who are regarded as having honesty and integrity. Two defendants were represented by an attorney who has a considerable civil and criminal practice, and who is very highly regarded by the local bench and bar. The names of the other attorneys representing the thirty-seven remaining defendants were not recognized at sight by the court personnel.

\section{"Quick justice"}

Since the DeMeerleer ${ }^{16}$ case, in which the United States Supreme Court reversed a Michigan Supreme Court decision

${ }_{16}^{6}$ DeMeerleer v. People, 67 Sup. Ct. 596 (1948) reversing 313 Mich. 548. The later decision in Bute v. Illinois, 333 U.S. 640 (x948) is confusing. One practical result of the DeMeerleer case, in recorder's court, has been an avalanche of demands for new trials.

Rule 22: "All motions for nolle prosequi and all guilty pleas must be heard by the presiding judge. The trial judge may accept a plea ... only when a defendant changes his plea during a trial. . ." This rule is often circumvented by allowing jeopardy to attach (which occurs after the plain- 
upholding a murder conviction based on an unrepresented defendant's attempt to plead guilty to a lesser offense, all criminal courts in the area take pains to guard against "quick justice." In recorder's court, special pains are taken because the size of the case load, the short term of the presiding judge, and the rapidity of the handling of cases render personal knowledge of the entire progress of any one case by anyone representing the public a practical impossibility. Court rules requiring nolle prosequi motions and guilty pleas to be heard by the presiding judge, and requiring the taking of testimony and the making of a finding by the presiding judge prior to acceptance of a plea of guilty to a lesser included offense, are stringently enforced at present. The cases investigated by this writer, as shown in the preceding pages, included two felony trials in which defendants were unrepresented, so far as the files showed. Court personnel, however, state that: "Whenever any felony defendant goes to trial he must be represented by counsel, either retained by him or assigned by the court."17

\section{c. Counsel for Prosecution and Defense in Traffic and Ordinance Court}

Many of the fines imposed are collected summarily by mail or by payment at the cashier's cage. In these cases, as to the number of which information was not obtainable, there is no attorney for the defendant. Attorneys very

tiff has offered any piece of testimony) and then offering a plea to the assigned judge.

Rule 30: "When a defendant offers to plead ... to a lesser included offense, ... complainant or some other material witness... shall ... satisfy the judge that ... such a plea would not operate as a miscarriage of justice ... and is ... consistent with the ... facts. ..."

17 Supra p. Ir2. Letter to the writer from E. Burke Montgomery, clerk of the recorder's court, dated June 20 , 1950 . "In only one instance since I have been connected with the court has a defendant stood trial without the aid of counsel. In that particular case counsel had been assigned but defendant refused his aid. Counsel stood by and the defendant convicted himself. The court aided him in questioning witnesses and he was offered every assistance." 


\section{II4 METROPOLITAN COURTS: DETROIT AREA}

rarely appear in ordinance matters. The cases on which warrants are issued, always tried by judges, are presented by assistant prosecutors only in such grave matters as manslaughter and the like. Courtroom observation indicates that in most of the cases, the judge questions the witnesses and conducts the trial.

The chief deputy clerk of the traffic and ordinance division advises that of the $6,36 \mathrm{I}$ accident prevention bureau cases disposed of in $1947,,^{18}$ there were 632 appearances by defense counsel. In this group of serious felony trials, in other words, less than ro per cent of the defendants were represented by counsel. In another group of cases tried by judges, appearances of counsel were noted in 27.5 per cent of the cases. ${ }^{18}$

\section{d. Counsel in Probate Court}

The register and three assistant registers, who are all attorneys, spend much of their working time advising litigants about procedure with regard to filing petitions and other necessary routine steps to be followed in matters under the jurisdiction of the court. Printed forms are supplied to litigants by the court personnel. Each judge employs his own order clerk to draft and prepare orders which are to be entered. In the mental division, the head of the division interviews all petitioners and witnesses, and drafts the petitions. After the hearing, this officer also prepares the orders for the judges to sign.

A deputy register estimates that about 20 per cent of

18 The accident prevention bureau is a specialized bureau of the Detroit Police Department, which receives assignments to investigate and testify concerning major accidents.

${ }^{19}$ A group of cases including felony and high misdemeanors, such as "drunk driving," reckless driving, leaving scene of accident, et cetera. These cases were tried between January 1,1948 , and June 30 , 1948. Both checks were conducted at the writer's request by the chief deputy clerk of the traffic and ordinance court. 
estate cases go through without attorneys. In the mental division, the court now and then appoints a guardian ad litem, who may or may not be an attorney. During observation of more than two hundred mental cases, attorneys for defendant were seen in only one case, that of an elderly wealthy merchant, recently married, whose brothers had filed a petition for commitment. The weight of the mental case load is heavy: each of the five judges ordinarily devotes one day a week to such cases, during which he hears a docket of twenty cases. The head of the mental division explains the absence of attorneys in terms of the low economic status of the typical defendant and the unlikelihood that an attorney could help anyway. The Legal Aid Bureau of Detroit advises that its policy is not to act for defendants in mental cases, because the mental division of the court is equipped to advise them.

\section{e. Counsel in the Juvenile Court}

In a mimeographed descriptive report prepared by the court it is said:

"delinquent children . . . are given a thorough social investigation. . . When . . . the child is brought before the Judge . . . he does not have to cringe before a Prosecuting Attorney, for there is no prosecution in the Juvenile Court. . . . The child need not employ defense counsel, as there are no legal pitfalls to guard against or judicial technicalities or devices to employ. . . ."20

The informal nature of the proceedings at juvenile court, the large amount of work done on an unofficial basis, and the closely protected record, tend to discourage the hiring of attorneys to represent the juveniles. ${ }^{21}$ No prosecutors

20 "The Wayne County Juvenile Court, Detroit, Michigan," op. cit., p. 4. The material is not dated.

21 As to the efficacy of this "protection," see infra pp. $238-240$. 
attended the juvenile court in Detroit in 1947 or 1948 , and no counsel were assigned to the defense, although the statute authorizes assigned counsel at public expense in juvenile cases. Observation indicated that attorneys sometimes but not often appear in delinquency and adoption matters, almost never in other cases. Apparently the disuse of attorneys is typical of modern juvenile courts, which emphasize co-operation with social service agencies, and which have deliberately moved away from the traditional methods of the judicial process. Judge Alexander, of the Toledo juvenile court, in his report to the Family Life Conference in 1948 said: "We seldom see a lawyer in juvenile court -and when we do, we have to tell him what to do and how to do it."

\section{f. Counsel in the Common Pleas Court}

More than 90 per cent of the case load of this court is disposed of on default. ${ }^{22}$ The assumption is that in these cases, the defendant is unrepresented.

By court rule, ${ }^{23}$ deputy clerks are appointed to assist litigants who are not represented by counsel in the preparation of their statements of "claim, declaration, answers, and motions wherein the amount involved is not greater than fifty (\$50.00) dollars."

In practice, a printed card suggesting the advisability of obtaining counsel is handed to litigants asking advice about matters where the amount is over $\$ 50$. If the litigant, after reading the card, again asks for advice, aid is given him.

\footnotetext{
2290.7 per cent, or $37,7 \times 5$ cases, in $1947 ; 95.4$ per cent, or $51,329 \mathrm{cases}$, in 1948.

23 Rules: Common Pleas Court for the City of Detrort, effective May I5, 1936, rule 32 .
} 
g. Counsel Supplied by Legal Aid Bureau of Detroit

This organization is supported by the community chest. It supplied aid in the disposition of 18,299 cases in 1947 , of which 435 were court cases. ${ }^{24}$ It does not advise those who are able to obtain advice elsewhere. The bureau does not handle criminal cases (since statutory provision is made for assigned counsel at public expense), nor does it supply legal aid to defendants in mental cases. It does not send lawyers into juvenile court, because the services of a lawyer are not regarded as very effective in that court, and because the statute provides for assigned counsel at public expense.

\section{h. Comment on Use of Counsel}

Since the amount of litigation conducted without counsel in all courts but the circuit court is startling, inquiries were directed to judges, court employees, newspapermen, litigants, social workers, and others as to the reasons for it. The following reasons were most often suggested:

I. The growing availability and extensive use of social service and medical personnel;

2. The increasing importance of the "social problem" type of case, which largely involves persons who cannot afford counsel;

3. Size of case load, and the necessity for guarding against lawyer-based delays by employing as part of the court organization enough trained legal personnel to keep the docket moving;

4. Dissatisfaction with performance of lawyers.

24 Information supplied by members of the legal aid bureau staff, and from their 1947 report. 


\section{Section 2. Trial Juries}

a. Right of Jury Trial

The Michigan constitution guarantees the right of trial by jury, and specifically, of one accused of crime to a trial by a jury of twelve except in courts not of record..$^{25}$ But the constitution permits the legislature to authorize a trial by a jury of less than twelve men. ${ }^{26}$ The effect of modern socialized techniques for dealing with juvenile offenders and with mentally abnormal offenders, such as are in use in the Detroit metropolitan district, is to substitute expert diagnosis and treatment by social workers and psychiatrists for the traditional safeguard of the trial by jury. The inevitable result is conflict. In a case dealing with an earlier attempt to provide specialized juvenile court machinery, including a jury of six for juvenile cases, for Wayne County, it was held that such a provision violated the right of one accused of crime to a trial by a jury of twelve. ${ }^{27}$ The present statute regulating the juvenile court eliminates the criminal nature of the proceedings and destroys the identity of "delinquency" proceedings as such. ${ }^{28}$ It also provides for a jury of six. ${ }^{29}$ It might be regarded as a legislative impairment of the right of one accused of crime to have a jury trial by a jury of twelve. ${ }^{30}$

In the realm of medicolegal problems, the first "Criminal Sexual Psychopath Act," which substituted psychiatric diagnosis and hospitalization for trial and imprisonment of those who, though not legally insane, suffer from mental

25 Constitution of Michigan (I908), art. II, $\S$ I3; art. V, $\S$ ig.

26 Ibid, art. V, $\S 27$. But this section seems to be applicable only to civil cases. See Robinson v. Wayne Circuit Judges, 15 I Mich. 315 (I908).

27 Robinson v. Wayne County Circuit Judges, loc. cit.

28712 A.1-2 CoMp. LaWs (1948); 27.3778 (57 I-2) Mrch. Stats. AnN.

29712 A.r7 Comp. Laws (r948); 27.3178 (598.17) Mrch. Stats. Ann. (Supp.).

30 For a discussion of the effect of such statutes on the constitutional right to a jury, see 67 A. L. R. ro82. 
abnormalities resulting in criminal propensities to the commission of sex offenses, was held unconstitutional as violating the right of trial by jury. ${ }^{31} \mathrm{~A}$ later statute to the same effect has been declared valid, but in a very recent case a psychiatrist's report made under the statute was found to amount to a deprivation of the constitutional rights of the defendant, because it set forth "medical conclusions" instead of "legal facts." with murder must be examined by a sanity commission consisting of three state-appointed psychiatrists, and, if found insane, acquitted and committed to the state hospital for the criminally insane at Ionia, is another example of the substitution of medical diagnosis for the right to trial by jury. $^{33}$

b. Methods of Selection

In general

The governor is required by statute to appoint a threeman board of jury commissioners in each county for courts of record therein. ${ }^{34}$

In the Circuit Court of Wayne County as compared with other courts in the state

Under a special statute regulating Wayne County alone, the governor appoints seven persons-five from Detroit and two from outside the city-to the board of jury commissioners of Wayne County. ${ }^{35}$ This board divides the terri-

31 People v. Frontczak, 286 Mich. 5 I (1938).

32 The present statute was upheld in People v. Chapman, 30r Mich. 584 (1942). See 38 Mrch. L. Rev. 1316. The case referred to is People v. Artinian, 320 Mich. 44I (1948).

${ }^{33} 766.15 \mathrm{a}-\mathrm{d}$ Comp. Laws (1948); $28.933(\mathrm{x})-(4)$ Mich. Stats. Ann. (Supp.).

34 602.150 et seq. Comp. Laws (1948); 27.275 et seq. Mich. Stats. Ann. 35 69r.411 et seq. Coмp. Laws (1948); 27.4II et seq. Mich. Stats. AnN. 
tory into seven districts of which five are in the city, and each commissioner makes a list of jurors, by automatically selecting every seventh name on the poll list, once each term, or once a month except July and August. The entire board then approves the entire list, and the prospective jurors are summoned to attend before the presiding judge, to fill out questionnaires, and to present matters relative to exemption or excusal.

From the complete list of 300 names, each name is written on a separate strip of paper and placed in a "jury box" which is then sealed by the county clerk. Fourteen days before each term, the commissioners, in the presence of the presiding judge, the sheriff and the county clerk, draw out of the box as many jurors as may be needed. Jurors report to the presiding judge for verbal instruction and to be sworn in.

\section{By the Circuit Court Commissioners of Wayne County}

Landlord-tenant juries are governed by the statute governing justice court juries, which requires only that a proper person of the county write down the names of eighteen persons and that six names be chosen from the list. ${ }^{36}$ In practice, the commissioners obtain the list of eighteen names from those drawn by the Wayne County Jury Commission.

\section{In the Probate Court}

There is no provision for juries in probate court except in mental cases. ${ }^{37}$ Juries for such cases are summoned "as

36 27.1975 Mich. Stats. Ann.; 630.x Comp. Laws (1948), and 670.13 Comp. LaWs (1948); 27.3266 Mich. Stats. AnN.

37 330.21 Comp. Laws (1948); $14.81 \mathrm{r}$ Mich. Stats. Ann. And see In re Bristol, 199 Mich. 453 ( 1923 ) (no right to jury for guardian's accounting); In re McNamara's Estate, I66 Mich. 45I (xgII) (no right to jury for administrator's accounting); Lewis M. Simes and Paul E. Basye, Problems in Probate Law, Including a Model Probate Code and Monographs (Ann Arbor: The University of Michigan Press, 1946), pp. 54, 149-I50.

But it should be born in mind that in a case where the right to a jury 
in railroad condemnation cases," 38 which is to say, by impanelment by the judge from twelve county freeholders whose names have been assembled by the sheriff under court order. The services of the Wayne County Jury Commission are not used.

\section{In the Juvenile Court}

The statute regulating the court provides for a jury of six to be impaneled as in justice courts. ${ }^{39}$

\section{In the Common Pleas Court}

There is no statute providing for juries for this court; wherefore, the statute governing juries in justice courts governs. ${ }^{40}$ In practice, however, the court draws from the lists assembled by the board of jury commissioners of Wayne County. Jurors report every morning for roll call to the presiding judge of the common pleas court. This court limits jury cases to the first two weeks of each term.

\section{In the Recorder's Court}

Formerly supplied by the Wayne County board of jury commissioners, the recorder's court has had its own jury commission since 1923 , consisting of three members appointed by the governor, which prepares lists twice a year from registered city voters by means of the key number

exists, one can, by appeal or transfer to the circuit court, obtain access to the jury there. See 7or.36 Comp. Laws (r948); 27.3r78 (36) Mich. Stats. ANN. for appeal and transfer statute.

See $9 x$ A. L. R. 88 for discussion of the propriety of handling insanity hearings without juries.

38 253.14 Comp. Laws (I948); 9.xr13-4 Mich. Stats. Ann.

39 712A.I7 Comp. Laws (1948); 27.3178 (598.17) Mrch. Stats. Ann.

40 728.19 Comp. Laws (I 948 ); 27.3670 Mrch. Stats. Ann.; 727.15 Comp. Laws (r948); 27.3625 Mrch. Stats. Ann. And see Rules: Common Pleas Court for the City of Detrort, effective May 15, 1946, rule 30. 
system, a method of automatic selection by means of an integral quotient obtained by multiplying the estimated total number of jurors by three or another number, and then dividing the total number of names by such result. ${ }^{41}$

The judges semiannually estimate the number of jurors needed. Each month, the presiding judge and the clerk attend the drawing of names from the jury box, at which time the judge breaks the seal placed and signed by his predecessor the month before. After a check for eligibility, jurymen are summoned before the commission, which superintends the filling out of questionnaires and administers the oaths. Each panel serves four weeks. When finally selected, the names of those on the panel are printed on sheets of paper called "boxes," each of which contains twenty-four to forty names, for use by various judges. The entire panel reports to the presiding judge for instruction and for final excusal where appropriate.

\section{In the Traffic and Ordinance Court}

This court shares the recorder's court panel. A separate "box" of names is printed for its use. Jurymen in this "box" report directly to the presiding judge at the traffic and ordinance court. ${ }^{42}$

41 725.102-157 CoMp. LAws (1948); 27.397x-4032 Mich. Stats. AnN. Act 364 , P.A. 1921, which first authorized the establishment of a separate jury commission for recorder's court, was held unconstitutional in People v. Cathey, 220 Mich. 628 (1922), because that statute, which did not require a referendum, contravened the Constitution of Michigan (1908), art. VIII, $\S 6$. Detroit has adopted the present act by referendum.

${ }^{42}$ After the traffic and ordinance court was held to be a court within a court, having distinct jurisdiction from recorder's court, the sharing of the jury panel was challenged, in Atty. Gen. ex rel. Judges Recorder's Court v. Judge Recorder's Court, 250 Mich. $44^{8}$ (1930), wherein it was held that the regular panel at recorder's court is available to the traffic and ordinance tribunal. And see supra chap. II, n. 5 r. 
In the city courts outside Detroit

Home rule cities with home rule courts are covered by a special statute governing juries. ${ }^{43}$ In Dearborn and Highland Park, juries are selected under the Flint Act. ${ }^{44}$ Township justices are covered by the general statute applicable to justices. ${ }^{45}$

\section{Comment on the methods of selecting juries}

A study made in 1939 by a member of the Detroit jury commission compares the methods of jury selection in Chicago, Ohio, New York, Buffalo, Philadelphia, Washington, D. C., Los Angeles, and Detroit. It indicates statistically the superiority of the key number system in solving the problem of bribed or otherwise "fixed" juries. As germane to this point, the author states that after the system had been in use for six years, 92 per cent of jurors were serving for the first time-an indication that the "professional" juror is eliminated by the key number system. ${ }^{4 B}$

\section{c. Extent of Use of Juries in Detroit}

\section{Use of juries in the Circuit Court}

A comparison of the extent to which juries are used in major civil and criminal litigation in the Detroit metropolitan area and in the remainder of the state is shown in the following table made up from official statistics published in the Eighteenth Annual Report of the Judicial Council of Michigan. Table XVIII covers all cases tried in all the circuit courts of the state during the year 1947 .

43 1 7 7.28 Comp. Laws (I948); 5.2107 Mich. Stats. Ann.

44 730.122 Comp. Laws (1948); 27.3852 Mrch. Stats. Ann.

45 i 7.30 Comp. Laws (I948); 27.3265 Mich. Stats. Ann.

46 John L. Whitehead, Methods of Selection of Trial Jurors (unpublished manuscript, r939). The point especially noted may be found at p. 20 therein. 


\section{TABLE XVIII}

\section{Circuit Court Jury Cases (1947)}

\begin{tabular}{|c|c|c|c|c|}
\hline ourt & $\begin{array}{l}\text { Civil cases } \\
\text { excluding } \\
\text { appeals }\end{array}$ & $\begin{array}{l}\text { Criminal } \\
\text { cases } \\
\text { excluding } \\
\text { appeals }\end{array}$ & $\begin{array}{l}\text { Justice and } \\
\text { municipal } \\
\text { court } \\
\text { appeals }\end{array}$ & $\begin{array}{l}\text { Probate } \\
\text { appeals }\end{array}$ \\
\hline & $\begin{array}{l}\text { Non } \\
\text { jury }\end{array}$ & $\begin{array}{l}\text { Non- } \\
\text { jury }\end{array}$ & $\begin{array}{l}\text { Non- } \\
\text { jury }\end{array}$ & Jury jon- \\
\hline
\end{tabular}

Circuit Court of

$\begin{array}{lllllllll}\text { Wayne County. } 124 & 275 & 52 & 82 & 33 & 108 & 0 & 3 & 696\end{array}$

All circuit courts

except Wayne

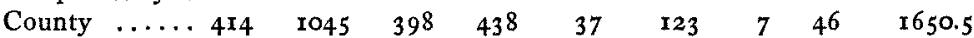

From the foregoing table it appears that in the state at large, 28.3 per cent of all the civil law cases tried (excluding appeals) were tried to juries. In the Circuit Court of Wayne County, 3I.I per cent of the civil law cases tried were tried with juries. In the state at large, excluding Wayne County, 47.6 per cent of the criminal cases tried (excluding appeals) were tried with juries. In the Circuit Court of Wayne County 36.I per cent of the criminal cases tried (excluding appeals) were tried with juries. From these figures it appears that in major litigation juries are used to substantially the same extent in the Circuit Court of Wayne County as in circuit courts outside Wayne County. No corresponding figures as to minor litigation are available.

The amounts of the civil judgments rendered in cases tried by judges and by juries, respectively, in the Circuit Court of Wayne County in the year beginning December I, I946, are analyzed in Tables XIX-XX.

Of $I, 23$ I cases in which plaintiffs recovered, 884 were nonjury and 347 were jury cases. In the nonjury cases, I 7.5 per cent of the plaintiffs recovered more than $\$ 1,500$. In the jury cases, I3.I per cent of the plaintiffs recovered more than $\$ 1,500$. In general, the recoveries in jury and nonjury civil cases in the Circuit Court of Wayne County appear from these figures to be substantially the same. 


\section{TABLE XIX}

\section{Judgments in Jury Trials}

\section{Circuit Court of Wayne County (1947)}

\begin{tabular}{|c|c|c|c|c|}
\hline Month & $\begin{array}{l}\text { Number of } \\
\text { cases } \\
\text { tried }\end{array}$ & $\begin{array}{l}\text { Number of } \\
\text { judgments } \\
\text { from } \\
\$ 1000-1500\end{array}$ & $\begin{array}{l}\text { Number of } \\
\text { judgments } \\
\text { from } \\
\text { under } \$ \text { rooo }\end{array}$ & $\begin{array}{c}\text { Number of } \\
\text { judgments } \\
\text { over } \\
\$ 1500\end{array}$ \\
\hline December $\ldots \ldots \ldots$ & 9 & 3 & 4 & 2 \\
\hline January $\ldots \ldots \ldots$ & 8 & 2 & 2 & 4 \\
\hline February $^{*} \ldots \ldots \ldots$ & 297 & 93 & 175 & 29 \\
\hline 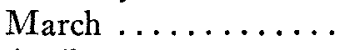 & 6 & $\cdots$ & 2 & 4 \\
\hline April $\ldots \ldots \ldots \ldots$ & 3 & . & 2 & $\mathbf{I}$ \\
\hline May ........... & 8 & $\mathbf{I}$ & 5 & 2 \\
\hline June $\ldots \ldots \ldots \ldots$ & 5 & 3 & $\mathbf{I}$ & $\mathbf{I}$ \\
\hline July $\ldots \ldots \ldots \ldots$ & I & $\cdots$ & $\cdots$ & $\mathbf{I}$ \\
\hline August $\ldots \ldots \ldots \ldots$ & . & . & . & $\cdots$ \\
\hline September ........ & 5 & $\cdots$ & 3 & 2 \\
\hline October .......... & 2 & $\cdots$ & 2 & $\mathrm{O}$ \\
\hline November ......... & 3 & $\cdots$ & I & 2 \\
\hline Total $\ldots \ldots$ & 347 & 102 & 197 & 48 \\
\hline
\end{tabular}

* A large number of judgments against the Detroit Street Railway were entered in this month.

\section{TABLE $X X$}

Judgments in Nonjury Trials

Circuit Court of Wayne County (1947)

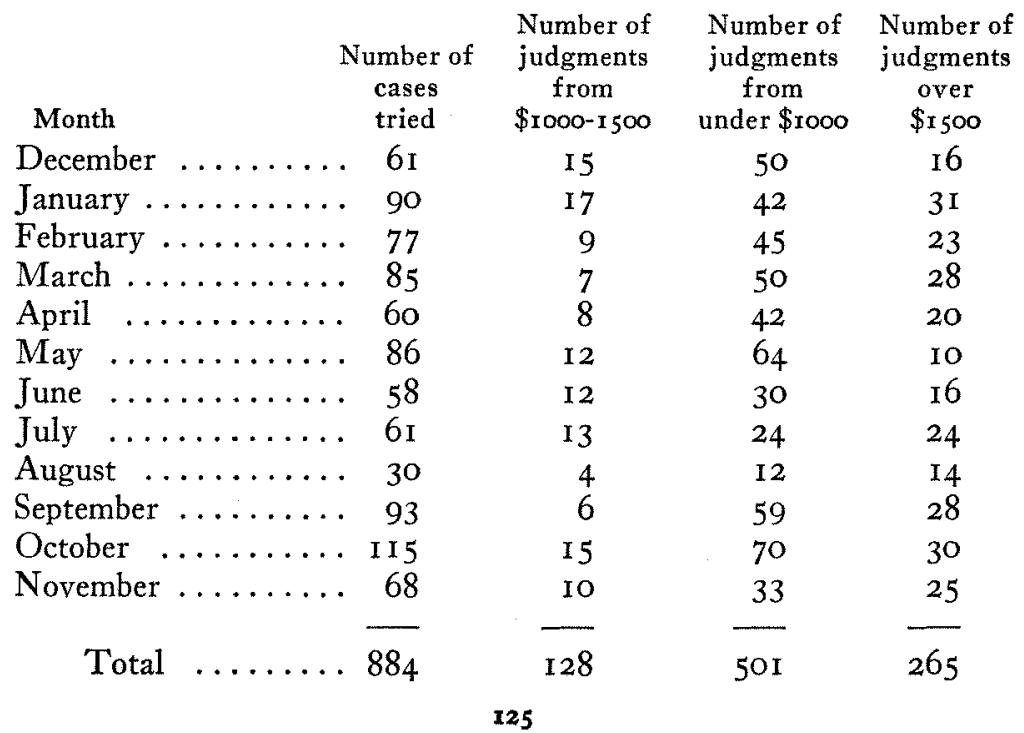


Waiver of juries is encouraged in the Circuit Court of Wayne County by giving docket precedence to court cases.

Use of juries in felony division, Recorder's Court

A total of 743 jury days were spent in the recorder's court, excluding condemnation juries, in both divisions. Information as to the exact number of jury days in each division is not available. Of $\mathrm{I}, 293$ felony cases tried in the felony division, which has jurisdiction in the same class of criminal cases as the Circuit Court of Wayne County, 943 , or 73 per cent, were tried by the court and 350 , or 27 per cent, by juries. In the jury cases 37.4 per cent of the defendants were acquitted; in the nonjury cases, 33.5 per cent. In $1948, \mathrm{I}, 635$ felony cases were tried, $\mathrm{I}, 363$, or 83.4 per cent, by the court, 272 , or r 6.6 per cent, by jury. In the jury cases 27 per cent of the defendants were acquitted, in the nonjury cases 20.8 per cent were acquitted. It would seem that defendants fared slightly better before juries than before judges.

\section{Use of juries in misdemeanor division, Recorder's Court}

In $1947,18,261$ misdemeanors were tried: 18,250 by the court, eleven by jury, or less than a tenth of I per cent. Of the defendants tried by the court, 9 per cent were acquitted. The number tried by jury is so small that the percentage of acquittals has no statistical value. In 1948 , I 7,422 misdemeanors were tried: I 7,404 by the court, eighteen by jury, again less than a tenth of $\mathrm{I}$ per cent. Of those tried by the court, Io per cent were acquitted.

\section{Use of juries in Traffic and Ordinance Court}

The chief deputy clerk advises that of I,789 cases tried by the court beginning January, 1948 and ending June $3^{\circ}$, I 948 , forty-eight, or 2.6 per cent, were jury cases. 


\section{Use of juries in the Probate Court}

There were 2,694 mental cases disposed of in 1947 , and about 500 more than that in the first ten months of 1948 . The register advises that no separate record is kept of jury cases, which are only available in mental cases in this court, and that it would be impractical to obtain such information from the court records. He states, however, that juries are used infrequently-perhaps in about one case in a hundred. Observation confirms this estimate. No juries were seen in the Probate Court during field work.

\section{Use of juries in the Juvenile Court}

No record is kept of jury cases, but the court statistician states that there have been none for several years. It would be possible to obtain jury trial by appeal to the circuit court, which would try the case de novo, but there have been no appeals from juvenile to circuit court in 1947 or 1948 .

\section{Use of juries in the Court of Common Pleas}

In 1947 , of $2,75 \mathrm{I}$ tried cases, 206 , or 7 . I per cent, were jury cases; in 1948 , of 2,284 tried cases, 326 , or 14.2 per cent, were jury cases.

Use of juries by circuit court commissioners

In 1947 , of 2,849 rent cases tried, $\mathrm{I}, 445$ were tried by juries, or 50.7 per cent.

Comment on extent to which juries are employed

If the relation of jury cases to all cases disposed of is examined, a very small total use of juries in the metropolis appears: In the Circuit Court of Wayne County in 1947, 4.2 per cent of civil law cases (excluding appeals) disposed of were tried by juries, as compared to 9.3 per cent in the 
circuit courts of Michigan excluding Wayne County. In the state at large excluding Wayne County, 47.6 per cent of felony cases disposed of (excluding appeals) were tried with juries, while the Circuit Court of Wayne County and the felony division of recorder's court together disposed of felony cases that year of which 2.3 per cent were tried with juries. It thus appears that in major litigation, the total use of juries is less in the metropolitan area than outside, and that there is a striking difference in the use of juries in felony cases.

Of 1,789 cases disposed of by the traffic and ordinance division for a six-month period beginning January, I948, 2.6 per cent were tried by juries. Of all misdemeanor cases disposed of in recorder's court during 1947 , juries were used in less than a tenth of I per cent. The relation of jury cases to cases disposed of in 1947 by the court of common pleas was approximately one half of $\mathrm{I}$ per cent. It is clear from these figures that the total use of juries in courts operating in the metropolis is exceedingly small, with the exception of civil cases in the circuit court and landlordtenant cases before the circuit court commissioners. The large percentage of jury trials in these cases may be related to the acute housing shortage in Detroit during 1947.

Even on the basis of the relation of jury trials to cases tried, the use of juries in the felony division of recorder's court, which tries major criminal cases in the city of Detroit, is considerably less than in the state at large excluding Wayne County. In juvenile court, the necessity for getting away from the traditional legal approach to children's behavior problems is a contributing cause of the decline in the use of both attorneys and of juries.

In the probate court, the lack of use of juries is due in part to a recognition that mental cases involve medical and social problems. The disuse of attorneys is no doubt 
ORGANIZATION : ATTORNEYS AND JURIES 129 related. This factor may be reflected again in the disuse of both juries and attorneys in the misdemeanor division, and this is born out by the large probation department and psychopathic clinic at the recorder's court. Another contributing cause to the disuse of juries here, as in the traffic and ordinance court, may be the size of the daily case load and the pressure on both sides of the case to obtain rapid disposition. 
Chapter V

\section{Organization of Courts in the Detroit Metro- politan District: Administrative and Clerical Personnel}

\section{Section i. Public Administrators}

T $N$ ESTATES where the decedent leaves no known heirs, or where there is no widow, husband, or next of kin resident in the state, or where, alternatively, there is no widow, husband, or next of kin residing in the United States or Canada who requests the appointment of a proper person to act as administrator, the state public administrator, an assistant attorney general appointed to act in this capacity, acts as administrator. The statute further provides that when the state public administrator, because of volume or nature of duties, shall deem it necessary, he may appoint any suitable and competent person to act as county public administrator at the pleasure of the state public administrator. ${ }^{1}$ Such persons are granted letters by the probate court. Unlike the state public administrator, who is prohibited by statute from receiving any compensation other than his state salary, county public administrators receive expenses, fees, compensation, and allowances by order of the probate judge and payable out of the estates for which the administrators act.

On April 8, I948, the Detroit Legal Nerws contained notices of appointment of a public administrator for the county of Wayne in the estates of over 947 persons. $^{2}$ It is

${ }^{1} 720.201-223$ Comp. Laws (1948); 27.2754 (1-23) Mrch. Stats. Ann. (Supp.).

2 P. 3 . 
a reasonable assumption that no county other than Wayne presents such extensive need for the use of county public administrators as is indicated here. The state public administrator advises that about $\mathrm{I}, 200$ petitions were filed in Wayne County in 1948 for administration of estates of persons having died leaving no known heirs, and that petitions under the code of escheats were filed in Wayne County in 1948 in 148 estates having a face value of $\$ 290,178.48 .^{3}$ He points out that in a majority of the former cases, heirs eventually are found or make themselves known. There are currently eight public administrators in Wayne County, under the control and supervision of the state public administrator.

\section{Section 2. BaIliff}

Process from recorder's and traffic courts is served by the police. Probate, circuit, and juvenile court process is served by the office of the county sheriff, and in these courts there are the usual arrangements for service by mail and publication.

In the Court of Common Pleas of Detroit, however, process (except replevin, execution, and attachment) is served by bailiffs appointed by the judges. Previous to I 943, the work was done by elected constables. Because the judges had insufficient control over constables, some of whom were shown to be guilty of gross misconduct, ${ }^{4}$ the statute was amended to require service by bailiffs. Constables serving at the time the statute went into effect were required to be appointed bailiffs. ${ }^{5}$ There are at this time a total of fortyfour bailiffs, two for each ward.

${ }^{3}$ See 567.1x et seq. Comp. Laws (1948); 26.1053 (x) et seq. Mrch. Stats. AnN. (Supp.); and 720.201 et seq. Comp. Laws (1948); 27.2754(1) et seq. Mich. Stats. Ann. (Supp.).

"Joseph A. Gillis, "The Constables and the Conciliation Division," 5 Detroit LAW QUARTERLY, no. 2, p. 8.

5 728.1 et seq. Comp. Laws (I948); 27.365I et seq. Mrch. Stats. Ann. See also Rules: Common Pleas Court for the City of Detrort, effective May I5, 1946, rule 34 . 
Bailiffs are furnished headquarters by the county auditors in a building across the street from the courthouse, but when working they wear city badges of office. Each day they call at a counter which contains a number of slots, each marked with the name of a bailiff and containing summonses to be served. To his individual slot, at various times during the day, each bailiff returns summonses marked with proofs of service. At the end of each day, each bailiff calls at the clerk's office to receive payment for work done that day. On March 19, I948, a date chosen at random, the sum of $\$ 609.60$ was paid to bailiffs. At the time each suit is filed, $\$ 3.50$ must be paid by each plaintiff; there is no way in which an indigent plaintiff can, by taking a pauper's oath, escape this payment. Of this sum $\$ 2.50$ is allocated to the bailiff for serving the summons.

If the first writ is not served, an alias summons may issue, for which the bailiff is paid anew. Personal service is required on the first writ, but substituted service is permitted thereafter. If the second, or alias, writ is not served, a pluries summons may issue. For serving this third summons, the bailiff is paid another fee.

During the active period of the conciliation division, it was found that in many default cases coming to the court's attention when the defendant's wages were garnished, no proper service had been made on the defendant. A schoolteacher alleged to have been personally served in July proved she had been in Indiana continuously all summer; a man was shown to have died months before the date of alleged service; another man was in the hospital for weeks before and after the date of the so-called personal service at his residence on which the default judgment had been based. In other instances, it was found that constables had deliberately connived with plaintiffs to make returns of personal service without actually serving the writs in order 
that defendants might be prevented from appearing and answering claims which contained illegal interest, items for payments made but not properly credited, accounts on which the statute of limitations had run, and other claims to which a full or partial defense might have been made. At that time it was estimated that twenty-five commercial firms and collection attorneys handled two thirds of the cases coming before the court, and that the percentage of defaulted cases was over 60 per cent. ${ }^{6}$

In 1947 , the percentage of defaulted cases at common pleas court was over 90.3 per cent; in $1948,95.4$ per cent. $^{7}$ There does not appear to be any method whereby the court is currently able to check the accuracy and bona fides of service in defaulted cases. Of 537 summonses disposed of between January I3, 1948, and January 19, 1948, 274 were served on the first summons, and hence necessarily received personal service. One hundred and forty-one in the same group were served on the second (alias) summons, and twenty-nine were served on the third (pluries) summons. While it is possible that some of those served by alias and pluries summons received personal service, the overwhelming majority of such summonses are served by substitution-i.e., by leaving a copy of the summons at the residence of the defendant with a person more than eighteen years of age. Thirty-two summonses out of the 537 were dismissed for no service. Sixty-one pluries summonses were still pending.

All but thirty-two of the above cases, or 505 thereof, represented defendants whose residences the bailiffs were able to locate. Yet only 274 were personally served on the first summons. The results of the above check, which was made by the presiding judge at the writer's request, seem to bear out the presiding judge's estimate that a third

6 Gillis, op. cit. supra, n. 4 at p. 8.

7 Annual Report of Presiding Judge, for 1947 and for 1948. 


\section{I34 METROPOLITAN COURTS: DETROIT AREA}

or more of the summonses issued by the court are alias or pluries summons, and that most defendants in this group of cases are served by substitution.

The present statute, giving the court control over its bailiffs by making these officers appointive personnel, together with the very large percentage of default cases, constitute a very difficult problem of administration for the common pleas judges. The system of service now in use makes falsification of returns easy and rewards failure to make service of the first summons, and hence encourages substituted service. The coexistence of many default judgments and of many alias and pluries summonses suggests the existence of a problem of exercising effective control over the accuracy of the service as well as the legality of default judgments. In common pleas court, which rendered 40,466 judgments in 1947 and 54,814 judgments in $1948,{ }^{8}$ the number of summonses served in a year makes the problem of policing its process servers unlike that encountered by nonmetropolitan courts with similar jurisdiction.

No other court operating in Detroit attempts to administer its own process serving personnel. There are twenty deputy sheriffs called "bailiffs" assigned to courtroom duty in the Circuit Court of Wayne County, but these officers, though they act as courtroom attendants for the judges, are not on the court pay roll, nor do they serve process, which is handled through the sheriff's office. In probate court, some process is handled through the sheriff's office but the court employs five process servers who have had experience in handling mentally afflicted persons, since the problem of approaching such persons with notice that a mental petition has been filed requires discretion, tact, and specialized skill. These process servers render other court

${ }^{8}$ Annual reports of the presiding judge to Common Council of the city of Detroit, r947 and r948. 
services also. Juvenile court employs no process servers, and recorder's and traffic and ordinance court employ none. There is a semipermanent police detail of fifty-two men at recorder's court, but these officers act as courtroom assistants for the judges, and perform duties such as escorting prisoners to and from places of detention and the courtrooms and serving subpoenas, capiases, and condemnation notices.

\section{Section 3. Clerical Staffs}

\section{a. In General}

A notable difference between courts operating in the city of Detroit and those operating outside the city limits is the large number of employees attached to each of the Detroit courts. These courts are multi-judge courts, and the methods of employment, control, and division of labor among their employees present important problems.

These problems do not arise in the outlying portions of the metropolitan area. Township justices operate without help of any kind, and most of them run other businesses as well as their courts. City justices sometimes have one clerk, and sometimes, when pressed, call upon local police for help. In larger cities where there are two justices, a single clerk is sometimes employed to keep the files of both. ${ }^{\circ}$ Most home rule courts ${ }^{10}$ get along with one clerk, and with such part-time help from the police as is necessary for courtroom work.

In Dearborn, the staff consists of a court clerk, deputy court clerk, two typists, and one probation officer. This staff also serves as a violation bureau staff. ${ }^{11}$ In Highland Park, the staff consists of a court clerk, a deputy court clerk, three stenographers, and three process servers. ${ }^{12}$

9 As in Hamtramck.

$10 \mathrm{As}$ in River Rouge.

11 Letter from presiding judge dated December I6, I948.

12 Information supplied by clerk as of December 28, 1948. 
The Probate Court of Oakland County employs twentythree persons, the Probate Court of Macomb County twelve persons. ${ }^{13}$ The Circuit Court of Oakland County employs eighteen persons, that of Macomb County nine persons. ${ }^{14}$

In contrast, each of the courts operating in Detroit employs more than roo persons except the probate court, which employs more than seventy-five, full time..$^{15}$

\section{b. Court Reporters}

In the Circuit Court of Wayne County, court stenographers are appointed by the governor. ${ }^{16}$ There are eighteen, which is one for each judge. Each of the five probate judges has a court reporter whom he appoints. Recorder's court has eleven judge-appointed reporters. At juvenile and at traffic court the judges' secretaries act as court reporters when need arises. In common pleas court, litigants must hire their own court stenographers if they wish to have a record made. ${ }^{17}$

${ }^{13}$ Information supplied by judges, as of May $15,1949$.

14 Letter from chief deputy clerk, Oakland County, May 9, 1949. Information for Macomb County, in absence of a reply to a request by the writer for information, was calculated from the county clerk's DiREcToRY OF COUNTY OfFicials (1948).

${ }^{15}$ See Appendix $B$ for charts of each of the courts operating in Detroit, and see Table XXI, infra p. 193 .

${ }^{16} 691.302$ Comp. Laws (1948); 27.33 I Mrh. Stats. Ann.

17 This was changed after the period covered by the survey. P.A. no. r49, 1949 provides that appeal or certiorari shall lie from a decision of the court of common pleas "but not for trial de novo, where the case shall be reviewed in the same manner ... as cases appealed from the circuit court are now reviewed in the supreme court. . ." Provision is made for bond, for filing of transcripts, and for the employment of a reporter or stenographer upon demand of either party to the case, or on order of the court; "said stenographer shall be paid by the county on a per diem basis by order of the trial judge." The party demanding the stenographer is required to pay the sum of $\$ 3.00$ for the stenographer. In practice, the stenographers are sent down by the Circuit Court of Wayne County, which is housed on another floor of the same building as that occupied by the court of common pleas. 
c. Clerks

\section{In the Circuit Court of Wayne County}

In general. Wayne County alone of the counties in Michigan has a civil service commission, which determines the duties and compensation of "unclassified" employees of the court-i.e., those whose appointments are not specifically provided for by statute. ${ }^{18}$

The county clerk is the clerk of the circuit court, in Wayne as in any county. ${ }^{19} \mathrm{He}$ has administrative control over court personnel.

The numerical disposition and the functions of the various members of the court's clerical staff may briefly be outlined as follows :

Courtroom clerks. There are twenty-two courtroom clerks in the Circuit Court of Wayne County. They are appointed by the county clerk. In practice, the county clerk permits each judge to approve or reject such appointments in advance. In addition to answering questions for litigants and attorneys, calling cases, and in general assisting the judge, the courtroom clerk has important duties with respect to the official record of the cases tried or otherwise disposed of in each courtroom. A "short book," which is a longhand summation of action taken on each case, is kept in each courtroom. This book remains in the courtroom as a permanent record of each day's work, and serves as a memorandum from which journal entries are drawn. "Court sheets"20

18 45.8 I CoMp. Laws (r948); 5.1191 (I) Mich. Stats. Ann. The statute applies to Wayne County only (300,000 population) but provides for other counties to have civil service by referendum after reaching that population. First statute was held unconstitutional in Malloy v. Wayne County Board of Supervisors, 246 Mich. 632 ( 9229 ) as prohibited local legislation. The present statute has been declared valid in Duncan v. County of Wayne, 316 Mich. 513 (1947), which also upheld the authority of the commission in such a way as to affect its duties and salary.

19 zor.12 CoMp Laws (1948); 6.702 Mrch. Stats. Ann.; 602.65 Comp. Laws (1948); 27.202 Mich. Stats. Ann.; Mich. Const. (I908) Art. VII s. 1 I. 20 See Appendix B. 
are also kept in each courtroom. Prepared in triplicate on printed pads designed by the presiding judge for the purpose, these sheets also contain a brief longhand summary of action taken in each case. A copy goes to the Detroit Legal News, one to the county clerk, and one to the assignment clerk.

Actual orders of disposition-"journal entries"-are ordinarily drafted, in this court, by the courtroom clerks, although in some cases attorneys draft the entries, and in occasional important cases the judges draft them.

County clerk's office. The county clerk has some employees who are not concerned with the operation of the circuit court. The following employees under his immediate control are on the court pay roll and are occupied with duties related to the operation of the court:

( I) One deputy county clerk acts as assistant to the county clerk.

(2) A cashier and assistant cashier receive and dispense funds for the court or as directed by court order.

(3) Four clerks operate the "front counter"-i.e., they provide information concerning records, receive papers in suits being commenced, and receive pleadings and other documents for filing and entering in suits already pending.

(4) There are sixteen record clerks. The permanent official record of the court consists of a law journal and a chancery journal for each judge: thirty-six journals in all. The law journal is assembled from data sent downstairs from each courtroom, and consisting of the original file and of the "court sheet." Two clerks are employed to type material into each judge's law journal. This law journal contains identifying material, a résumé of previous pleadings, and complete copies of all disposing orders. Disposing orders are typed directly from the original file into the journal. Chancery journals also contain complete copies of 
disposing orders and sufficient narrative material adequately to describe the nature of the litigation and of previous action therein, but chancery journals are photostated directly from the original documents in the litigation file, and after photostating are assembled into separate journals for each judge. Journals are signed by each judge about once a month in open court.

Record clerks also prepare and keep a "calendar," an unofficial record of the nature, progress, and disposition of all cases, identified by chronological number. The calendar is prepared directly from the litigation file, which is then deposited in a filing cabinet by one of the clerks. Special records are kept for "no progress" ${ }^{21}$ and for appeals cases.

The county clerk is responsible for the care and custody of all court records. ${ }^{22}$

Assignment clerk. The assignment clerk has four assistants. He works directly under the presiding judge to assemble dockets and assign cases. The duties of the office are elsewhere described. ${ }^{23}$ There is a court librarian, who is classified as part of the assignment clerk's office, but whose duties consist of operating the library maintained by the court.

Circuit court commissioner's clerk. Under this official, who is under the supervisory control of the presiding judge, are four courtroom clerks and fifteen office clerks. The records and files of the circuit court commissioners are kept in a separate office on a different floor from those of the circuit court, and are handled by an entirely separate and self-contained system of files and records.

The probation officer's clerks. Nine clerical and stenographic employees are assigned to the probation officer, whose operations are described elsewhere. ${ }^{24}$

22 602.65 Comp. Laws (1948); 27.202 Mich. Stats. AnN.

23 Infra pp. 197-x99.

${ }^{24}$ Infra pp. 152-1 56. 


\section{I4O METROPOLITAN COURTS: DETROIT AREA}

Friend of the Court's clerks. Approximately thirty stenographic and clerical employees, one cashier and approximately fourteen assistant cashiers, are assigned to this office, the duties of which are elsewhere described. ${ }^{25}$

\section{In the Probate Court of Wayne County}

In general. The register is the executive officer of the court; he is appointed by the judges and subject to removal by them. ${ }^{26}$ Judges are also permitted by statute to appoint deputy registers and clerks, and to prescribe their duties. ${ }^{27}$ In Wayne County these powers are subject to the authority of the civil service commission which exerts some control over the employees of the court. There is an area of confusion between the court and the commission as to the exact boundaries of this prerogative.

The various subdivisions of the staff, by number of personnel and duties, are briefly classified as follows:

Judges' staff. The court clerk of each judge notes on each petition heard the date and nature of any disposing action taken by the judge. This is called the "endorsement" system. The official order is drafted, sometimes years later, by one of five order clerks. Each judge has, in addition to a secretary, an order clerk who is not an attorney. ${ }^{27 a}$ These clerks work independently, drafting orders from the original files as indicated by the "endorsement" on each one. Ten typists, or two to each clerk, are assigned to this work. The finished orders are signed by the judges. On April I 5, I 948, a day picked at random, one probate judge was signing orders for December 1943 .

Register. The register drafts certain official orders of a

${ }^{25}$ Infra pp. 173-181.

26 7or.13 Comp. Laws (1948);27.3178 (13) Mich. Stats. Ann.

27 7or.14 Comp. Laws (1948); 27.3178 (14) Mich. Stats. Ann.

27 a $A$ letter from the register of the court, dated June $16,195^{\circ}$, indicates that the statement in the text is now partially incorrect. He states that "two of the five clerks are attorneys, but we try in every case to have attorneys on these particular jobs." 
routine nature in estate matters. ${ }^{28} \mathrm{He}$ has his own secretary to whom he dictates such orders. Under the register are the following subdivisions :

(I) Certified copies: An assistant register, who is an attorney, and three typists are assigned to this work.

(2) Calendar: An assistant register, who is an attorney, and six typists, handle this department.

(3) Publications: An assistant register, who is an attorney, and three typists draft and prepare publication notices and advise litigants.

(4) Information: Three clerks, supervised by the register, meet and route persons having business in the court or wanting information about litigation in progress.

(5) Files and records: Three clerks are assigned to placing material in files and obtaining files which are required.

(6) Claims and bonds: One clerk and two assistants supply litigants with printed forms and assist in the filling out of forms.

Inheritance tax. The court employs one examiner; another employed by the state spends about half his time checking receipts in the Probate Court of Wayne County.

Mental division. The head of this division has three typists and drafts his own orders. This division operates as a separate and specialized unit, as elsewhere described, ${ }^{29}$ although it is under the supervisory authority of the register.

\section{In the Juvenile Court of Wayne County}

The executive and administrative officer of the court is the register, who is appointed by the judge. ${ }^{30} \mathrm{He}$ has his

28 7or.12 Comp. Laws (1948); 27.3178 (I2) Mich. Stats. Ann.

29 Infra pp. 186-192. See Appendix B for complete chart of court, and Table XXI, infra p. 193 for total number of employees.

${ }^{30} 72$ A.7 Comp. Laws (1948); 27.3178 (598.7) Mich. Stats. Ann. 
own secretary. Employees of the court are under county civil service.

Official court orders are drafted by the judge, or by one of the referees. Sometimes, observation indicated, the order is actually drafted for the judge or referee by a probation officer having knowledge of a case. ${ }^{30 a}$

Records are in the custody of a chief clerk, who also handles files, dockets, collections, bookkeeping, and stenographic personnel. Ten employees are assigned to the chief clerk. They include clerks and typists. The judge dictates orders to his own secretary, as does the register when acting as referee. Other referees or probation officers apply to the register for a stenographer who is assigned as needed from a stenographic pool of twenty-two phonotypists. No clerical staff is assigned to the boys', girls', or "dependent-neglect" departments, each of which draws from the stenographic pool.

An attorney is employed by the court as statistician, and has a clerk assigned to him. The clinic for child study, elsewhere described, has three typists. ${ }^{31}$

\section{In the Recorder's Court}

Recorder's court employees, unlike those of other courts operating in Detroit, are not under civil service. Except for court reporters and employees attached to the probation department staff, they are paid by the city, after appointment by the judges. In addition to a city salary, the clerk receives from the county a fixed sum in lieu of fees formerly paid him for making out felony commitments. This arrangement is by agreement between the clerk and county fiscal

30a Upon reading galleys, the register of the juvenile court makes the following comment as of June 16, 1950: "Official court orders are drafted by the judge or by one of the referees. Sometimes the order is actually drafted for the Judge by the Referee having knowledge of the case."

31 Infra pp. 183-186. See Appendix B for complete chart, and Table $\mathbf{X X I}_{\text {r }}$ p. 193 for total number of employees. 
officials. The clerk controls court employees subject to the judicial authority. He has power of suspension..$^{32}$

Disposition and functions of employees concerned with records are, briefly, as follows:

Judges' staff. Each judge has a courtroom clerk, who prepares a daily "court sheet" ${ }^{\prime 33}$ containing a summary of action taken in each courtroom. This sheet goes to the clerk at the end of each day, together with the litigation file which is stapled into a flat file folder. On the inner manila surface of the folder the courtroom clerk has noted in summation the date, the name of the judge, and the nature of the action taken in the courtroom.

Clerk's office. There are several subdivisions within this office, as follows:

(I) Felony records: From the files and court sheets, two deputy clerks draft an official journal entry for each felony case, and type the entries into pages which are fastened into the journal book, which is signed every day by the recorder. An unofficial record called a "calendar" is also prepared by one of two clerks. The calendar is a brief longhand summation of the progress and disposition of each case, identified by chronological number. A still more succinct tabulation of the progress of any case is the "index," or "ouija board," a large double-page book about the size of a newspaper, which is mounted on a wooden stand and in which all relevant information about the felony cases is entered in tabulation form by a deputy clerk. ${ }^{34}$

32725.4 Comp. Laws (1948); 27.3944 Mich. Stats. Ann.; 726.9 Comp. LAws (r948); 27.3559 Mich. STATs. AnN. as adopted by referendum. Beck v. Keidan (192r) $2 x_{5}$ Mich. 13 (clerk's right of suspension, subject to hearing before judges if desired).

33 See Appendix B.

34 The "ouija board" contains the following headings across each double page: "file no., def., offense, counsel, date warrant issued, date arraigned on warrant, plea, bail, jail or bond, bond no., examination, bail, jail or bond, bond number, file to pros., date returned with info., arraigned on info., plea, bond, trial date, trial judge, verdict, date sentence, file no., sentence, notes." Ninety-nine cases can be tabulated on one double sheet. 


\section{I44 METROPOLITAN COURTS: DETROIT AREA}

Other clerks are engaged in filing, in preparing subpoenas, and in handling statistics. The docket clerk, a deputy clerk with the responsibility for preparation and orderly movement of the felony docket, has duties which are elsewhere described. ${ }^{35}$ One clerk is assigned to appeals.

There is one librarian, an attorney. The clerk has a secretary who also performs stenographic work for the judges on occasion. There is a chief deputy clerk with the general duty of acting as chief assistant to the clerk.

(2) Warrant clerk: The warrant clerk, with four assistants, draws all warrants in both felony and misdemeanor cases.

(3) Bail bond bureau: A clerk and two assistants handle all bail in felony cases, by a system which requires that every payment be cleared by that bureau. Where cash is not paid and real estate is offered as security, titles are checked with the county register of deeds and with tax records both for valuation and for encumbrances, before acceptance.

(4) Misdemeanor division: No official record need be kept of misdemeanor dispositions. The court sheet serves as an unofficial record. Misdemeanor files are in the custody of the warrant clerk, who prepares a final order in such misdemeanor cases as require it. Most such cases are handled by the use of printed forms which, when filled in, adequately indicate the charge and progress of the case as well as the disposition. In addition to the warrant clerk's staff, one clerk working in the clerk's office proper is assigned to misdemeanors.

Psychopathic clinic. This administrative agency, elsewhere described, has its own clerical staff, consisting of about four typists and clerks. ${ }^{36}$

Probation department. This administrative agency, else- 
where described, ${ }^{37}$ has its own clerical staff apart from the clerk's office. During observation there were approximately six typists and clerks in this department. Many probation officers do their own paper work.

County auditor. The county has an employee stationed in the clerk's office for the purpose of conducting a continuous check on money received by the court for the county. Each court sheet shows the fines and costs received, and from the court sheets the county representative is able to check the actual cash turned in from each courtroom at the end of the business day. ${ }^{38}$

\section{In the Traffic and Ordinance Court}

Much of the traffic case load in Detroit is disposed of by payment of scheduled fines to the violations bureau, which is a part of the police department rather than the court. Although a statute permits the court to establish its own violation bureau, this has not been done.

The chief deputy clerk of the traffic and ordinance court is the executive officer of the court, and handles records, cases, and personnel entirely separately from recorder's court, the clerk of which is ex officio clerk of traffic and ordinance court under the statute. ${ }^{39}$ There is some occasional consultation on budget and personnel. Statistical and financial reports of recorder's court do not include traffic and ordinance court matters. Traffic employees are paid by the city, and are under city civil service.

A good deal of the court case load is disposed of by payment at the cashier's window prior to court day. In these cases, the defendant signs a printed confession of guilt

${ }^{37}$ Infra pp. $156-\mathrm{r} 65$.

${ }^{38}$ See Appendix B for chart of the court; Table XXI, p. 193, for total personnel.

39 See supra pp. 46-47. 
which constitutes the court record of the offense and its disposition.

Felony cases, which are always tried by the judges, are handled much like those in recorder's court: journal clerks draft journal entries from court sheets prepared by the courtroom clerks, and the completed journal is signed by the presiding judge.

The handling of money received by the court, and of unofficial records of ordinance and misdemeanor cases, necessitates the employment of a large staff of clerks. The chief deputy clerk has a secretary, an administrative assistant, an accountant, and several statisticians under his personal eye. Also immediately under the chief deputy clerk are two head clerks, each with five subdivisions consisting of cashiers, mail clerks, stenographers, journal clerks, and counter clerks. One head clerk has ninety-three clerks under him, the other eighty-five. The exact functions and assignments of the clerks vary from time to time as the case load varies. ${ }^{40}$

\section{In the Court of Common Pleas}

The clerk is the administrative officer who directs the clerical staff and the bailiffs. Clerical employees are paid by the county and are under county civil service. Although the court is not a court of record, it is required that papers shall be filed and judgments indexed. ${ }^{11} \mathrm{~A}$ card index is kept of all cases, by names of parties. Files of litigation are kept in folded manila envelopes, numbered chronologically. Complete journal entries are drafted and typed into each judge's journal by one of four journal clerks from information noted on the court sheet and the file jacket by

40 See Appendix B for chart of the court; Table XXI, p. I93, for total personnel.

${ }^{41}$ 680.I CoMp. LAWs (I948); 27.3529 Mich. STAts. ANN. 
courtroom clerks. Each judge signs his own journal. There is one courtroom clerk for each judge, and one extra for the presiding judge.

Under the clerk are two deputy clerks, one with sixteen employees assigned to commencement of cases and issuance of process, another with fifteen employees who work on bookkeeping and financial entries. A third deputy clerk receives daily reports from each courtroom and prepares monthly and yearly statistical reports. Twenty-seven clerks assigned to partial payment, assignment, journal, file preparation, and docket are responsible directly to the clerk. ${ }^{42}$

\section{d. Comment on Drafting Journal Entries}

The most striking feature of the recording system used in the Detroit metropolitan area is the fact that the actual drafting of the journal entries is entrusted to nonlegal personnel employed by the court. This means that the crucial part of the official record is drafted by persons who, in most cases, are not attorneys. The use by courts of their own employees for this task is doubtless one result of the necessity of keeping the docket moving.

\section{e. Periodical Reports}

The most important collector of court statistics in Michigan is the Judicial Council of Michigan, a state agency established in 1929 for the "continuous study of the substantive law of the state and of the organization, rules and methods of procedure and practice of the judicial system of the state, the work accomplished and the results produced by that system and its various parts." Clerks of courts and other officials are required by the statute to make

42 See Appendix B for chart of the court, and Table XXI, p. 193, for total personnel.

${ }^{43}$ 691.31 Comp. Laws (I948); 27.I I Mich. Stats. Ann. (1949) Supp. 


\section{I48 METROPOLITAN COURTS: DETROIT AREA}

such reports to the judicial council, from time to time, as the council may prescribe. The circuit courts and the recorder's court make detailed reports to the council covering volume of business, case disposition, condition of docket, use of juries, use of visiting judges, types of cases, and considerable other data which are analyzed and published in the council's annual report.

The published figures of the council do not include courts of limited jurisdiction; hence the figures for the misdemeanor division of the recorder's court are not included in detail. None of the other courts operating in Detroit reports to the judicial council, although the inclusion of some figures for the probate, juvenile, and traffic courts would be useful and informative.

Some information about criminal cases is collected every quarter by the state corrections commission from the police, the felony division of recorder's court, and from the circuit court. From time to time the United States Bureau of the Census and other federal agencies obtain various kinds of information about criminal cases from the same sources. At the time the data for this study were collected, recorder's court statistics were not assembled on the same basis as the police department statistics, and no statistics of the incidence of offenses by type of offense were kept. The circuit court makes an annual report on divorce cases and certain other cases to the state association of circuit judges.

The juvenile court, though required by statute to "furnish the state juvenile institute commission an annual report of the administration of the juvenile division in such form as shall be recommended by the Michigan probate judges' association . . " ${ }^{44}$ did not, according to the 1946

${ }_{44}^{712 A .28}$ Comp. Laws (1948); 27.3178 (598.28) Mich. Stats. Ann.

On June $16,195^{\circ}$, the register of juvenile court reports: "We are now reporting under the 'Juvenile Court Reporting System.' The functions of the Juvenile Institute Commission have been transferred to the State Department of Social Welfare." 
report of the association, report except as to official delinquency cases, because court personnel deem that the policy of protected record prohibits the disclosure of other data.

The probate court, according to its register, makes no annual report of a statistical nature, employs no statistician, and keeps no record of its case load. The head of the mental division keeps a department record by month and year of the work of that division, which is filed with the register annually.

The traffic court makes an annual report to the Common Council of the city of Detroit in the form of a one-page summary of aggregate case load, receipts, and types of disposition of certain principal traffic offenses.

The presiding judge of the court of common pleas makes an annual report to the mayor and Common Council of the city of Detroit in the form of a two-page letter summarizing the total dispositions, the number of contested dispositions, the total amount of all judgments rendered, and the hours of service of the judges.

There is no attempt by any court operating in Detroit to integrate its statistical records with those of any of the other courts operating in Detroit. The various items recorded, the time units used, and the statistical methods employed are so unlike, indeed, as to make comparison of the operation of the various courts, from these reports, a practical impossibility in all but a few over-all general categories.

Section 4. Administrative Agencies Performing Administrative and Supervisory Services for Courts

a. Probation Agencies

\section{In general}

The trial court's power to substitute probation for imprisonment of one convicted of a criminal offense extends 
to all crimes and misdemeanors except murder, treason, robbery while armed, and breaking and entering in the nighttime. ${ }^{45}$ It has been extended by the juvenile court statute to include children under the juvenile court jurisdiction, although proceedings in that court are not criminal in nature. ${ }^{46}$ It has been held that convictions of ordinance violations will support probation at least where the offense is also against the statutes. ${ }^{47}$ Probation is not a right, but "a matter of grace," terminable or revocable at the discretion of the court, applicable in case of "any antisocial act," after a summary informal hearing not subject to rules of evidence or pleading. After revocation, the court may sentence as if no probation had occurred, or may make "such disposition of probationer" as the court deems will best serve the public interest. ${ }^{48}$

Conditions of probation must include compliance with all laws, physical presence of probationer in the state, and the making of such reports as the officer may require. Permissive conditions may include sixty days' imprisonment, whole or partial restitution, repayment of any direct or indirect expenses to which the public has been put in connection with the litigation, including but not limited to ordinary costs. Conditions may also include "such other lawful conditions" warranted by the circumstances and proper in the judgment of the court. ${ }^{49}$ For example, several assault and battery cases have been observed in which defendants have been required, as conditions of probation, to remain sober, to support their families, and to maintain steady employment. Repayment of funds received from public assistance agencies is a frequent condition of probation.

45 771.1 CoMp. Laws (1948); 28.113 M Mich. Stats. Ann.

${ }^{46} 712$ A.9 Comp. Laws (1948); 27.3I78 (598.9) Mich. Stats. Ann.

(Supp.).

${ }^{47}$ People v. Sarnoff, 302 Mich. 266 (1942).

48 771.4 Comp. Laws (I948); 28.1 34 Mich. Stats. Ann. (Supp.).

4977 1.3 Comp. Laws (1948); 28.r133 Mich. Stats. ANn. 
In some cases, submission by defendant to psychiatric treatment is made a condition of probation.

A misdemeanor conviction may result in two years' probation, a felony conviction in five years' probation. ${ }^{50}$ Thus a court, by choosing probation, may maintain control of a defendant for a longer period of time than would result from imprisonment, since statutory sentences for many offenses are shorter than the maximum probation term, and since many sentences may be further reduced by parole or pardon. The term of probationary control may be further lengthened where one who has been on probation for a time is convicted of violation of probation and is once again placed on probation for this new offense. In several observed cases, criminal defendants were placed on probation because it offered a longer period of contact with the probationer than imprisonment-e.g., one convicted of a petty assault, whose previous record showed homicidal tendencies but who could not be institutionalized as psychotic, and another, of previous good habits and tender years, convicted of accosting and soliciting, whom the probation officers wished to protect for as long a time as possible in order to frighten away commercial vice agents.

In the state at large, the department of corrections has "general supervision over administration of probation," but in counties with a population of over 500,000, which means Wayne County, the courts supervise their own probation officers. ${ }^{52}$ These officers, for whom there are no statutory qualifications, are appointed by the state corrections commission after recommendation by the judges. ${ }^{53}$ It is notable that when sentence is imposed, control of the convicted person passes from the trial court to the bureau

5077 I.2 Comp. LaWs (1948); 28.1132 Mich. Stats. Ann.

5177 1.7-77r.1o Comp. Laws $(1948) ; 28.1937-40$ Mrсh. Stats. AnN. (Supp.).

52 79x.26 Comp. Laws (1948); Mich. Stats. ANn. 28.2166.

53 Supra n. 5 r. 
of pardons and paroles, a state agency. ${ }^{54}$ Thus, in Wayne County, where the court controls its probationers through control over its probation officers, a court may preserve its control over a defendant by choosing probation rather than by passing sentence, which would end the court's control.

Probation department of the Circuit Court of Wayne County

The present staff consists of a chief probation officer, an assistant chief, a women's director, nine probation officers, and nine clerical and stenographic employees. Their work is divided into two distinct functions, as follows:

Pre-sentence investigation. When a person is found guilty of a felony, the statute requires that a probation investigation be conducted covering the "antecedents, character and circumstances" of the convicted person. A pre-sentence investigation is optional in misdemeanor cases. Probation reports with findings and recommendations are made in writing to the judge. The probation officer himself attends the court when the case is called to make such further oral reports as the judge may require.

The pre-sentence investigation consists of an interview with the defendant and a check of his previous criminal record. In this court, it also includes one or more interviews with the spouse and perhaps other members of the defendant's family, his employer, and as much information as the officers can get about previous and present court contacts with other courts operating in the metropolitan district and with public and private relief agencies. Where found advisable by a member of the department or requested by the court, further information may be assembled

54791.32 CoMp. Laws (1948); Mich. Stats. ANn. 28.2172. 
by interviews with complaining witnesses, neighbors, friends, case workers, police officers, religious leaders, members of service or veterans' organizations, physicians, or other persons having knowledge of the defendant. Probation reports are confidential except as to officers or court officials of the court conducting the investigation. On the basis of the report, supplemented as the judge sees fit, the court decides whether to sentence the defendant or place him on probation.

If the case goes on probation, the probation department will exercise the second of its duties, namely:

Supervision of probationers. This process consists of such contact with and knowledge of the probationer as is necessary to encourage the rehabilitation of the probationer and to inform the court as to his community adjustment. The supervision of various probationers varies to conform to the gravity of the offense, the age and circumstances of the probationer, the number of persons dependent on probationer for support, his responsiveness to his probation officer, and other factors. At minimum, however, probationers are required to make periodical reports to the department headquarters in the Barlum Tower in Detroit, and are the objects of periodical visits made by probation officers. The length of the period is determined by the chief probation officer on advice of the investigating officer.

Each officer has a "beat" consisting of a certain portion of the county. Most of them work in the city of Detroit. The boundaries of each "beat" are subject to change by the chief probation officer as the case load and available staff make expedient.

Collection of family support. In almost three fourths of all cases under supervision, without regard to the nature of the offense, the supervision includes setting up and adminis- 
tering family budgets for the families of probationers. ${ }^{55}$ This is usually done by having one of the officers work out a budget with the probationer and his wife. If the family experiences difficulty in staying within the budget, as is the case in more than half the cases on budget, the department requires that the probationer bring his pay check in and let the officer distribute the money among the creditors and for various current expenses. The department actually receives the checks from the probationers' employers by direct mail in many instances. The chief probation officer showed the writer the records in a half dozen of these cases: in several, probationers were making three- to four-hundred dollars a month, and had been convicted of offenses not related to family support. The chief probation officer states in his current report that the main reason for the increase in his case load is the great influx of "illiterate, migrant workers" attracted to Detroit by high wages "with no conception of an orderly manner of living and never having maintained a wholesome pattern of conduct. High wages .. . and the inability to impose any semblance of self restraint, results in . . . the support of wives and children becoming a responsibility of this department." ${ }_{56}$ Earnings of probationers managed and disbursed to families total $\$ 6,000$ a month and require the services of a full-time cashier and bookkeeper. They totaled $\$ 44,216.26$ in $1947^{77}$ and $\$ 56,272.6 \mathrm{I}$ in $1948 .^{58}$

Collection of restitution, court costs, and fines. In the year ending June 30 , 1948, \$24,866.04 was paid in restitution, $\$ 9,472.24$ in court costs, and $\$ 603.93$ in fines, to the

55 Informed estimate of the chief probation officer.

56 Probation Department of Circuit Court, Twenty-Fifth Annual Report, the Third Judicial Court of Michigan, July r, 1947 to June 30 , 1948, at p. I.

5i Twenty-Fourth Annual Report, Department of Probation, the Third Judicial. Court of Michigan, July I, I946 to June 30, 1947, p. XI.

58 TWenty-Fifth Annual Report, p. XI. 
probation department by probationers, and by the department remitted to the person or agency entitled to reimbursement. The total collected by the department in that year was $\$ 91,319.82$, an increase of 23 per cent over the previous year. ${ }^{59}$ This total includes amounts collected in family support.

Personal relationship between probation officer and probationer. The chief probation officer in his 1948 report, commenting on the "intangible values which develop out of personal relationships," points out that the real service of the department consists of the advice and the understanding guidance of officers. ${ }^{60}$ The failure of the family and community to furnish helpful human contacts brings the individual into conflict with the judicial process, in many instances, and thus intensifies the problem of the department. Since members of the staff must be able to establish contact quickly with their probationers, it is not surprising to find that the probation officers are either experienced social service executives, trained case workers, or are currently taking social science courses.

Supervision often includes finding a job for the probationer. In one case, this necessitated finding presentable clothes for him. In budget supervising, the officer often performs such family case work as reconciling estranged spouses, preventing hasty marriages, encouraging the wife to substitute sewing or literary club membership for the society of tavern companions, enrolling children in scouts, boys' clubs, or other youth activities, obtaining medical, dental, or psychiatric treatment for some member of the probationer's family, or obtaining food and clothing in an emergency for a distressed family in a probationer's neighborhood during hours when public relief agencies are closed.

59 Loc. cit.

${ }^{6}$ Ibid., p. $\mathrm{I}$. 
Extent of use of probation in Circuit Court of Wayne County. During the fiscal year ending June 30, 1947, the circuit court placed 133 persons on probation. Threehundred and nine were on probation at the beginning of the year, 789 were on probation at the end of the year. ${ }^{61}$ The judges vary widely in their use of probation. As of June 30 , 1947, the number of offenders held on probation by the several judges ranged as follows: one judge had none, seven others had less than ten, nine judges had between ten and twenty-five, and one judge-the presiding judge, who takes all arraignments-had I $23 .^{62}$ By June 3 O, I 948 , 853 were on probation. Between 1947 and 1948 , there was an increase of 13.2 per cent in the number of such cases. ${ }^{83}$

\section{Probation department of the Recorder's Court}

A single probation agency organized under the I9I3 act $^{64}$ functioned for ten years for both the Circuit Court of Wayne County and the recorder's court, but in 1923 a separate department was set up for recorder's court, which now operates independently of the circuit court. ${ }^{65}$

It was once the practice of some recorder's court judges to have the probation department and the psychopathic clinic-a recorder's court administrative agency for the diagnosis of mental deviations in criminal offenders ${ }^{60}$ - conduct investigations and make reports prior to the determination of the guilt or innocence of the defendant. In People $v$. Mayrand, ${ }^{67}$ however, the court's decision that a defendant may not be convicted by testimony taken outside the courtroom was so vigorous as to cause the recorder's court to

61 Twenty-Fourth Annual Report, pp. VII-VIII.

62 Ibid., pp. IV-VI.

63 Twenty-Fifth Annual Report, pp. VI-VII.

64 See citations supra pp. 149-152.

65 77x.7 Comp. LaWs (r948); 28.1137 Mich. Stats. Ann.

66 See infra pp. 181-183.

67300 Mich. 225 (1942). 
refrain, thereafter, from making any use of its investigating staff until guilt has been established. In the Mayrand case, the defendant's attorney had agreed to pre-trial reference to the probation and psychopathic clinic departments, and had further agreed that the judge might read the reports before deciding the case. The Michigan Supreme Court held that the attorney's agreement was "largely responsible for the irregular procedure" which had deprived the defendant of a fair trial.

There are fifty-five probation officers in the recorder's court and this staff serves both the recorder's court and the traffic and ordinance court. They are appointed by the corrections commission upon recommendation by the judges, and are paid by the county. Although there are no professional qualifications and the staff is not under civil service, there are currently eight attorneys and twelve professional social workers among the officers at the court. The department is divided into four specialized sections, all of which are under the authority of the chief probation officer and are actively supervised by the deputy chief probation officer.

Pre-court adjustment section. The director and three probation officers have the single task of attempting to persuade men to support their wives and minor children without the issuance of an official complaint for criminal nonsupport. The court has no jurisdiction over any of this section's case load; the section serves entirely as a screening agency which, by family case work and by unofficial collection of support money, reduces the official nonsupport case load of the recorder's court.

Nonsupport by a husband is a misdemeanor on the first two complaints and a felony on the third, but where minor children are involved, a felony complaint may issue the first time. ${ }^{68}$ When a wife has received no money for two

68 750.161 Comp. Laws (1948); 28.358 Mrch. Stats. Ann. 
continuous weeks and is without means of support for herself and children, and when she applies to the police or the prosecuting attorney for a warrant for her husband's arrest, she is referred to the precourt adjustment section, which sends her husband a card asking him to come in for an interview. A probation officer interviews both husband and wife to find out how much money the wife needs and the husband can pay. The policy is first to attempt to reconcile the spouses. Failing this, the husband is asked to pay directly to the wife whatever amount the probation officer has decided upon. If he is unwilling to pay the wife, he may pay the money at regular intervals to the precourt adjustment section, with the understanding that if he fails to keep up the payments, a recommendation for a warrant will be signed by the director of the section, whose signature is required before any warrant for criminal nonsupport will issue in the city of Detroit.

The section handles an average of 600 cases a month, of which about sixty result in warrants. In March of I948, 867 cases were handled without warrants, sixty warrants were issued, and $\$ 12,2 \times 2.50$ was collected from husbands for family support. ${ }^{69}$ The director declined to disclose the total case load handled or the total amount collected in either 1947 or 1948 .

A substantial number of women are referred to the section by one of the public or private relief agencies in the area. In January of 1948 , thirty-five cases were noted by the director as relief referrals. A destitute woman not referred by a relief agency is likely to be referred by a probation officer to such an agency, and in occasional hardship cases, the officer may make a telephone call to a relief agency. One of the probation officers in the section is a college graduate social science major with considerable case work

${ }^{69}$ Information supplied by chief probation officer. 
experience in one of the public assistance agencies in the city.

Once a warrant for the husband's arrest is issued, the precourt adjustment section's duty toward the case ceases, and the case passes within the control of another section of the recorder's court probation department, namely:

Domestic relations section. The work of this section, which is staffed by a director and eight probation officers, is restricted to domestic relations matters such as nonsupport, assault and battery arising out of domestic quarrels, and the like. Cases include both misdemeanors and felonies. The section conducts pre-sentence investigations to enable the court to decide whether offenders shall receive probation and, if so, on what terms. When offenders have been placed on probation after conviction for failure to discharge family obligations, the section supervises them.

In the year ending June 30 , 1946, nineteen pre-sentence investigations were conducted by the section; in 1946, thirty-seven; in 1947, fifty - twenty-two of the offenders were placed on probation and twenty-nine were sentenced. ${ }^{70}$ Investigations consist of an interview with the defendant and his wife, and with a probation officer from the precourt adjustment section if the case history includes contact with that division. The investigation may or may not include an inquiry into the present or past social service agency contacts of the family. The previous police record of the family is investigated, and anything in the court files of recorder's court pertaining to the family is checked. Contacts of the family with other courts are not checked unless they appear on the police record, except in certain cases.

Supervision of cases includes periodical office interviews with probationers, who report once a month or oftener, as required. An officer calls at each probationer's home at

${ }^{70}$ Information supplied by chief probation officer. 
least once a month, and calls occasionally at his place of employment. Other calls are made on neighbors, social workers from public or private agencies, and others, as the needs of the case dictate. Almost all persons under supervision make payments for family support to the section, and operate on a budget drafted and supervised by the probation officer-although some have been convicted of offenses other than nonsupport, such as drunkenness, disorderly conduct, or any other offense arising out of circumstances indicating failure of the family to maintain a wholesome domestic life. Planning and supervision of family budget is much the same here as in the circuit court. In the year ending June 30 , I946, a total of I,49 I probationers paid a total of $\$ 252,868.74$ in family support, which was collected by the section and distributed to the families and creditors of probationers. In the year ending June $30,1947,1,6$ 10 probationers paid a total of $\$ 299,756.46$ on budget supervision cases to this section. ${ }^{71}$

This section, like the pre-court adjustment section, is primarily devoted to the enforcement of the husband's obligation to support and maintain his wife and children. Any case in which there is a history of violence, degeneracy, neuroticism, or mental deviation, or which involves a major felony, is handled by one of the other two sections of the probation department. If the case can be adequately supervised by routine family case work and budget administration, it is handled by one of the two domestic sections, precourt adjustment, or domestic relations. If more delicate, specialized, or difficult supervision is indicated, one of the other two sections takes over the case.

Women's section. A director and ten probation officers comprise this section, which conducts pre-sentence investigations of women who have been found guilty of criminal

71 Information supplied by the chief probation officer. 
offenses, and which supervises women probationers. Most officers work on both supervision and investigation. Typical cases are those involving neglect of or cruelty to children, contributing to juvenile delinquency, sex offenses, and drunkenness.

During observation, a member of the section, always including the director herself, was assigned to work with each judge hearing misdemeanor cases. An officer on such an assignment goes into the prisoners' waiting room each morning and interviews all women prisoners who are to undergo court action that morning. Having taken notes on cases which deserve special handling, the officer then goes into the courtroom and stands at the side of the judge. Whenever a woman is found guilty, the judge turns to the probation officer, who then makes any recommendation she sees fit, such as adjournment pending a thorough investigation, or any other recommendation relevant to the sentencing, fining, or probation of the defendant. It was noted during observation that the officer from the women's section was consulted in virtually every misdemeanor case involving a woman offender.

In pre-sentence investigations other than those limited to short "waiting-room" interviews with misdemeanants, the section varies its requirements and practices with the needs of the case. Obtaining the confidence of the defendant is probably more difficult and more essential in this section than in any other. It is also frequently necessary, in order to safeguard the reputation of the defendant or to prevent further degeneration, to observe caution and discretion in investigation, as, for instance, in sex cases involving adolescent or previously uncharged girls. There is routine co-operation between the members of the women's division and private and public relief agencies in certain cases. The director advises, however, that there is no routine check 
with other courts which may have had contact with the defendant except as they appear on the police record. The section handles many cases involving cruelty to children, neglect of children, and failure to send children to school, but, because of the juvenile court's "protected record" policy, there is no co-operation between the probation officers of this section and the juvenile court, and no children are referred by this section to the juvenile court, although the director sometimes suggests to the women's division of the police department that such reference be made.

The practices of supervision in the section are flexible and conform to the needs of each case. A shoplifter may be required to make restitution for stolen goods and to obtain employment in wholesome surroundings. A neglectful wife and mother may be required to clean up her house and to take such care of her family as is acceptable to the probation officer, or may be required to be examined by the psychopathic clinic if the officer detects serious maladjustment. All women convicted of prostitution or like offenses, undergo physical examination and treatment for venereal disease if needed. Probationers are often required to conform to minimum standards of cleanliness, neatness, and modesty in dress. The director of the section places great stress upon the social rehabilitation of the women offenders, and places particular emphasis upon service to misdemeanants, who ordinarily offer greater opportunity of redemption.

During the fiscal year ending June 30 , I947, 405 cases were investigated, of which $\mathrm{I} 34$ were felonies and $27 \mathrm{I}$ misdemeanors. Eight hundred and sixty-nine persons were placed on probation to this section, of whom ninety-eight had committed felonies and $77 \mathrm{I}$ misdemeanors. ${ }^{72}$ Several officers, including the director, are graduates of colleges

${ }^{72}$ Information supplied by the director of the women's section. 
with social science degrees and social service experience. One officer is a graduate lawyer.

Men's section. The men's section, under a general director, is again divided into two subsections, namely:

Pre-sentence investigations. A section supervisor and ten probation officers conducted 1,924 , investigations in the fiscal year ending June 30 , $1947 .^{.3}$ Investigations include interviews with the offender, a check of his police record, and a check of his previous recorder's court contacts. Sometimes complaining witnesses, arresting officers, members of the family, relief workers, or others are interviewed.

One or more members of this subsection are assigned to each judge hearing misdemeanors. Such an officer interviews prisoners before trial, stands at the side of the "early sessions" judge at the trial, and when guilt has been determined, makes whatever recommendations he sees fit. For example, a case was observed in which a man convicted of drunkenness was a spastic paralytic, lived with an elderly mother who did not speak English, and was to all appearances suffering from mental illness. At the officer's suggestion, the sentence was deferred pending immediate hospitalization and psychiatric diagnosis, which the officer forthwith arranged.

In addition to the officers assigned to "early sessions" cases in general, one probation officer with specialized training and experience is permanently assigned to investigate persons charged with drunkenness, which, because of the size of the case load of this kind of case and because of the lack of statutory machinery for hospitalization of chronic alcoholics by recorder's court, is a serious problem to the court. This officer interviews all persons charged with drunkenness each morning. Most of the chronic repeaters are known to him. Those in need of psychiatric examination can be

${ }^{73}$ Information supplied by the chief probation officer. 
held for the psychopathic clinic at his recommendation. Others may appear, in the interview, to justify a thorough investigation, and still others may be best handled by suspending sentence and, in certain cases, by reference to Alcoholics Anonymous or to some other community agency outside the court.

Felony and misdemeanor supervision. This portion of the work of the men's section is under a separate supervisor and seventeen probation officers. This is one additional officer who serves as liaison worker between the investigation and the supervision officers in the men's section. Each officer has a geographic portion of the city as his "beat," and supervises all offenders residing within that "beat." One officer's case load was 183 felonies during observation. The city is divided into nine districts. Regular home calls are made once a month; probationers report at the office once a month. Each officer spends one day a week in office conference, the other days making calls. Additional supervision is given according to the needs of each case and the available time of the officer. In the fiscal year ending June $30,1947,972$ persons were on probation to this section. ${ }^{74}$

Extent and use of probation in the recorder's court. In the calendar year of 1940,719 persons were placed on probation by recorder's court; in 194I, 680 persons; in $1947,4,209$ persons; in $1948,4,533$ persons. ${ }^{75}$ During the fiscal year ending June $30,1947,3,380$ pre-sentence investigations were conducted by the entire probation department, and 5.732 were placed on probation. During that year, I,48 I persons were required to pay a total of $\$ 74,3$ I I.79 in restitution, and 867 paid an aggregate of $\$ 32,474.58$ in fines and costs. By 1948 , the total paid in restitution had reached $\$ \mathrm{IO}_{3}, \mathrm{I} 87 \cdot 33$. A total of $\$ 299,756.46$ was collected

${ }^{74}$ Information supplied by the chief probation officer.

${ }^{75}$ Information supplied by the clerk of the recorder's court. 
in family support throughout the department from probationers on family budget supervision to all sections, but this figure does not include the amount collected by the precourt adjustment section. ${ }^{76}$ Sixty-five per cent to 70 per cent of all probationers are on family budget supervision, and half of this number bring or send their paychecks in for the probation department to distribute, the chief probation officer advises.

Extension of probation to misdemeanants. The use of probation officers for investigation and supervision of misdemeanants in recorder's court is notable. In 1947, I9.3 per cent of all misdemeanants were placed on probation. In the year ending June 30 , 1947, of 3,380 pre-sentence investigations, the subjects of $\mathrm{I}, 26 \mathrm{I}$ were misdemeanants, as compared with 960 the previous year. Some judges regard this part of the department work as of great importance, since it protects minor offenders by placing them under supervision before major offenses have been committed, and also provides some limited safeguard against inadequate handling of cases by reason of the great size of the case load and the anonymity of the defendants.

\section{Probation department, Juvenile Court of Wayne County}

The juvenile statute authorizes the juvenile court to appoint probation officers. ${ }^{77}$ Under this authority, the Juvenile Court of Wayne County, instead of using the county agent as contemplated by the statute for child welfare work, restricts the use of the agent to investigating adoptions, and has appointed fifty-six probation officers. Although they are under county civil service, the statute relating to the appointment of probation officers in juvenile court provides that they hold office at the pleasure of the

${ }^{76}$ Information supplied by the chief probation officer.

77 Information supplied by the chief probation officer. 


\section{I66 METROPOLITAN COURTS: DETROIT AREA}

judge. ${ }^{78}$ Information as to the qualifications of these officers is not obtainable. The department is divided into three sections, as follows:

Boys' section. This section has a director who is also the chief probation officer, two assistant chiefs, and twenty probation officers, who handle delinquent boys from seven to seventeen years of age and wayward minor boys from seventeen to nineteen. Unlike the probation officers at recorder's and circuit court, who are prevented by the criminal nature of the proceedings from acting on any case prior to determination of guilt, the probation officers in this and other sections of the juvenile probation department handle their cases from the beginning.

The use of unofficial cases in the juvenile court has been described. ${ }^{79}$ In practice, anyone desiring the help of the juvenile court with regard to a boy whose behavior is regarded as delinquent goes directly to the head of the boys' department. In a preliminary interview, the director, who is also the chief probation officer, or an officer assigned by him, tries to work out the problem informally-that is, without even the exercise of unofficial jurisdiction. Where such a solution is not possible, the officer fills in a printed form which, if later signed, will constitute an official petition. Unsigned, the petition serves as a record of the child's name, his family and school history, the circumstances constituting delinquency, and the name of the referring social agency, officer, or private person. An investigation is conducted by one of the officers, each of whom covers a geographic "beat" in accordance with the chief probation officer's master plan. Since it is the policy of the court to protect its children by holding entirely confidential its dealings with them, nothing can be said about the nature of the

As stated in the text (p. I40), there is an area of conflict between judges and civil service commissioners as to the division of authority.

79 c...ken on on on 
investigation or the report which follows except that it is as required by the chief probation officer in each case. At any stage, the work may be suspended by informal settlement of the problem. If not, the unofficial case may go before the unofficial referee-the director or chief probation officer as he is also called-for a hearing and decision. The decision may be anything from a warning to arrangement for voluntary commitment of the boy to a public or private institution or school. If this unofficial decision of the chief probation officer of the boys' section qua referee does not dispose of the problem, the official petition is signed and sent to the chief clerk's office, where the case is entered on the official docket and set down for hearing before the judge or the official boys' referee. The official decision, if the matter actually comes on for hearing, may be official commitment of the boy to a public or private institution, placement on official probation, or the use of some private relief or religious worker as an "unofficial probation officer." Where commitment is decided upon, and the boy is less than incorrigible, the probation officer in charge of the case will probably be given an opportunity, by means of an unrecorded order, a suspended sentence, an indefinite continuance, or some such device, to bring the boy under control by using the official decision as a threat.

Because of the "protected record" policy of the court, it was not possible to examine probation records, to observe officers on field calls, or to read case files. The chief probation officer of the boys' section advises that in all but exceptional cases where directed by the judge himself, the "protected record" is enforced by declining to disclose the extent or character of investigation or action taken by the juvenile court when such information is requested by an officer from another court in the area. Such disclosures, it is felt, would

${ }^{80} 712$ A.28 Comp. Laws (1948); 27.3178 (598.28) Mich. Stats. Ann. (Supp.). 


\section{8}

become part of the inquiring court's probation report and hence of its official case record, thus violating the "protected record" statute which governs the juvenile court.

The official case load of the boys' section in 1947 was I,299 delinquent boys, and thirty-five wayward minors. The court statistician estimates the unofficial case load as about $500 .^{81}$ This seems conservative, in view of the fact that the juvenile bureau of the Detroit Police Department, with headquarters in the juvenile court building, reports having official knowledge in that year of 6,576 boys under seventeen on delinquency charges, of whom $\mathrm{r}, \mathrm{r} 83$ were unofficially and 890 officially referred to the juvenile court. Many of these were no doubt successfully handled "informally." 82

Girls' section. This section is known as the girls' department to the court. Its director is also its chief probation officer as well as its referee. There is an assistant director and fourteen probation officers. The work of the department is that of handling delinquent girls between seven and seventeen, and wayward minor girls between seventeen and nineteen. Many of these cases are sex cases. The official 1947 case load was 337 official cases, and the statistician estimated that fifty cases were handled unofficially. There were forty-nine wayward minor girls in that year. ${ }^{83}$ Persons having knowledge of facts constituting delinquency of a minor girl go directly to this section, which handles as many cases informally and unofficially as possible, and which places great emphasis upon maintaining complete secrecy.

Dependent and neglected children's section. This section is called the dependent-neglect department by the court. Its director is also its chief probation officer as well as its ref-

81 Information supplied by statistician.

82 Information supplied by police department, juvenile bureau.

83 Information supplied by statistician. 
eree. There is an assistant director and fourteen probation officers. By the function of the section some children "are removed from the custody of their parents and placed in boarding homes through private child-caring agencies at county expense, where they will receive proper care and supervision." ${ }^{14}$ Most of the cases are referred by social agencies after their efforts to obtain proper support and care have failed.

Officers in this section are authorized to provide clothing, medical care, or other necessary attentions for its children at public expense. A court order is prepared for each such expenditure. There is in the court a collection unit which obtains reimbursement from parents of amounts spent for the care of such children. Information about the amount collected was not obtainable.

No child is legally removed from the custody of its parents except by an official hearing conducted by the juvenile judge himself. There is great emphasis in this section upon co-operation with all of the public and private childcaring agencies in the area. A great many "unofficial" and "official" cases represent children whose parents have abandoned them, or who are eager to be rid of them. Many voluntarily surrender custody. The threat of deprivation of custody, unfortunately, is a less powerful sanction to this section than might be supposed. The official 1947 case load of the department was 437 cases, but since many families had several children, the load represented I,00o or more children, officers of the court advise. ${ }^{85}$

Extent of use of probation officers in juvenile court. The continuous use of probation officers throughout the entire progress of all but adoption and traffic cases is unique and important. Direct reference of cases to probation officers in

84 "The Wayne County Juvenile Court, Detroit, Michigan," op. cit., p. 2. The work is undated and mimeographed.

${ }^{85}$ Information supplied by the court statistician. 
the appropriate section, use of informal and unofficial cases, use of section directors as "unofficial referees," "protected record" policy, and the devices of holding official orders on suspension, continuance, or as unrecorded pending the probation officer's attempt to settle the problem with the order as a lever, all illustrate the extent to which the probation officers dominate the procedures and practices of the court. By these means the court is able to operate in each case through a single specialized child-welfare worker who can obtain the confidence and friendship of the child, and who can handle the case from beginning to end as the officer's professional skill and judgment dictate. It is the administrative discretion of the probation officer in this court which controls each case, and through which the court exercises its jurisdiction during the entire period of court contact.

Probation in city and justice courts in Wayne County outside Detroit

Dearborn has the only city court outside Detroit which employs a probation officer, so far as can be learned. ${ }^{86}$ In the city court of Highland Park, probationers are currently referred to the probation department of the Circuit Court of Wayne County, a privilege accorded by that court to any other court in the county.

Minor courts in Farmington, Royal Oak, and Bloomfield Hills report that they currently refer no cases to the circuit court probation officer; Sylvan Lake has referred one case, Grosse Pointe "several," Pontiac currently refers probationers either directly to the judge or to some citizen, and River Rouge referred seventy cases to the probation officer of the Circuit Court of Wayne County in 1947, and seventy-six in 1948 .

${ }^{86}$ Letters were sent to all courts in Wayne County outside Detroit, asking for this information. These data are compiled on the basis of the replies received, which are not complete for all courts. 
During the fiscal year ending June $3^{\circ}$, 1947, as reported by the probation officer of the Circuit Court of Wayne County, 486 persons were placed under his supervision by Wayne County justice and municipal courts outside Detroit, and in 1948,538 were so reported. ${ }^{87}$

\section{Comment on probation}

Recent growth in the size and use of probation departments in the criminal courts probably reflects the desire of courts to develop additional safeguards to offset the increased speed of disposition of each case brought about by the growth of case loads. The use of probation officers from the beginning throughout the entire period of contact, as in the juvenile court, may mark an important trend. The importance and difficulty of domestic cases in the metropolis is reflected by the great number of cases now on family budget supervision without regard to the offense committed by the probationer. The substantial use of restitution as a condition of probation tends to inhibit civil litigation. Probation provides a means of insuring continued control by the trial court, thereby enlarging the function of the court. The size of the probation staffs, and the number of professionally trained officers, accentuate the problem of adequate administrative control by the court over its own departments.

\section{b. Detention Home, Juvenile Court}

The statute authorizes the court to designate a place of detention for children found violating any law, or whose surroundings are such as to endanger their health, morals, or welfare, and to detain such child in the custody of a representative of the court pending a hearing. Any mu-

87 Twenty-Fourth Annual Report, op. cit., p. XII; and Twenty-Fifth AnNuAl Report, op. cit., p. XII. 


\section{I72 METROPOLITAN COURTS: DETROIT AREA}

nicipal police officer, sheriff or deputy sheriff, state police officer, county agent, or probation officer may detain such a child without a court order. ${ }^{88}$ Children may be detained for observation and study by experts, if release would endanger public safety, if they have run away from home, or if their home conditions make immediate removal necessary.

The Juvenile Court of Wayne County operates a detention home adjoining the juvenile court building. It has a staff of sixty-one: a superintendent, a boys' supervisor with thirty-five employees, a girls' supervisor with thirty-five employees, and a teaching staff paid by the city of Detroit but under the general control of the court and consisting of a director and seven teachers.

"A great many of the children who are admitted to the Detention Home are never brought into court for a formal hearing. They are released as soon as possible-usually in a few days. . . . Nor are all children . . . referred . . . for an official hearing detained in the Detention Home until that hearing. Only those are kept in the Home who either have no decent home to go to, or who would be a menace to the community if released prior to a plan of treatment being formulated." ${ }^{8}$

"Upon being admitted . . . boys and girls are given a physical examination and a complete clean-up. . . The staff . . i is composed of trained workers in the field of handling problem children, and their supervision is kindly and intelligent." ${ }^{90}$

During $1947,3,96 \mathrm{I}$ boys were admitted to the detention home, I, 263 girls. ${ }^{91}$ Children in custody from other courts, such as juvenile witnesses in criminal cases, are detained in the detention home.

88 712 A.r4-1 5 Comp. Laws (1948); 27.3 778 (598.14-15) Mrch. Strats. Ann. 89 "The Wayne County Juvenile Court, Detroit, Michigan," op. cit., p. 5. ${ }^{90}$ Ibid., p. 6.

91 Information furnished by court statistician. 
c. Friend of the Court

\section{In general}

In 1918, the presiding judge of the Circuit Court of Wayne County appointed an attorney experienced in social service to assist in enforcing court orders for the support of divorced wives with dependent minor children. In 1919, the legislature authorized the appointment of such an officer in every circuit to enforce delinquent support payments and to supervise care of minor children of divorced parents. ${ }^{92}$ The Friend of the Court is appointed by the governor after recommendation by the circuit judges. ${ }^{93}$ The authority and responsibility of the Friend has grown steadily.

In Wayne County, which is governed by a general statute applicable to all circuits, the size and functions of the Friend of the Court's office are many times greater than elsewhere. No other circuit has more than three or four employees in this office, while in Wayne County, there were over one hundred persons employed full time by the Friend of the Court. The Wayne County Friend of the Court is an attorney who represented the Detroit Legal Aid Bureau prior to the establishment of the Friend's office, and who has been the Friend since the system was organized. In Wayne County, he receives payment of all alimony and support, inspects all divorce pleadings for legality, sets the amount of support and names the custodian (subject to the court's final authority), and by a recent court rule, ${ }^{94}$ attempts to reconcile the parties to every contested divorce action and every such action in which the defendant has entered an appearance.

${ }^{92} 552.25$ r-4 Comp. Laws (r948); 25.171-4 Mich. Stats. Ann.

93 Loc. cit.

94 The court rule was adopted September 1,1948 , and is not contained in the printed rules printed in April of that year. 


\section{I74 METROPOLITAN COURTS: DETROIT AREA}

Although no special reconciliation division has yet been set up, as authorized, it is possible that the reconciliation function may eventually result in a regular pre-trial reconciliation hearing for all divorce actions filed in the court. Of reconciliation, the Friend says, in his 1948 report: "the desires of the husband and wife are ascertained. We encourage receptiveness, and if manifested by one or both of the parties, we endeavor to get them to change their thinking to what it was when they were courting each other. When there are small children, we then stand on solid ground to expound the handicaps, suffering and disillusionment of children of divorced parents. . . . We like to argue with parents that their children should not be denied their inherent right to live with their parents in a happy, contented home. . . . It is one of our major problems to adjust the attitudes of the parents, insofar as it concerns the best interests of the child." ${ }^{95}$

The rapidity with which the activities of the office are expanding in Wayne County may be noted by comparing the data given here with that presented in the study of the office of the Friend of the Court made in 1935 and published in the Fifth Annual Report of the Judicial Council of Michigan.

From observation, and from matter set forth by the 1948 report of the Friend of the Court, the organization and functions of the office are, briefly, as follows:

The Friend has one chief legal assistant and eight general assistants, who work directly with the Friend and outside the departmental organization. The subdivisions are not rigid, but there is interchange of personnel as the case load changes and as new decisions are made and policies determined. In general, there are three departments, as follows :

95 Annual Report of the Friend of the Court (1948), Circuit Court FOR THE COUNTY OF WAYNe, pp. I, 2. 
Investigation department. The staff of this department consists of two supervisors, twenty-two investigators, and about fifteen stenographic and clerical employees. The work of the department was in 1948 subdivided into sections, as follows :

Section concerned with reports and recommendations for temporary alimony. Pending divorce cases are investigated to ascertain the amount necessary to support minor children and wife, and reports made upon which the court bases an order for temporary alimony in each case. The largest number of reports in the department are filed from this section, the work of which is particularly critical, according to the Friend, because investigation occurs soon after separation, when "neither the wife nor the children have adjusted themselves . . . and they are generally in destitute circumstances." Because of the emergency nature of the work, a three weeks' maximum is permitted for preparation of reports. During 1948, 8, I 22 reports and recommendations were made by the section. ${ }^{97}$

Modification reports and recommendations. Where petitions for change of custody, modification of orders concerning support or alimony, visitation rights, or other miscellaneous matters are filed, the Friend conducts an investigation and makes a report and recommendation. Where possible, the Friend induces the parties in interview to reach an amicable settlement, and reports that in approximately one fourth of the cases (418 in 1948) such settlements were reached by mutual consent. In others, petitions for modification were discontinued after reports had been partially prepared. In 1948 , there were 1,737 modification reports filed from this section. ${ }^{98}$

Section concerned with reports and recommendations

96 Ibid., p. 3 .

${ }_{97}$ Ibid., p. 4.

98 Ibid., p. 6. 
affecting welfare of minor children. In all cases involving minor children, the Friend files a report on printed forms devised by the presiding judge and the Friend, and containing information as to the financial status of the parties, the home conditions of the minors, the children's present welfare, and other facts dealing with the present and future well-being of the children. ${ }^{99}$ From this report an assistant Friend of the Court, an attorney, drafts a recommendation as to the custodian of the children and the amount which the father should be required to pay for their support. In current practice, these recommendations are adopted by the court unless the attorney for the father serves notice three days before the hearing upon the Friend stating that the recommendations will be objected to, in which event an assistant Friend appears at the hearing. Observation indicates that the Friend's recommendations are seldom altered.

In $1948,4,539$ final reports and recommendations were filed from this section. ${ }^{100}$

Special investigation reports and recommendations. This section concerns itself with the interests of minor children of parents who have been divorced, by supervising their care, adjusting the "manifold difficulties arising between divorced parents in relation to their children," juvenile court proceedings where neglect or abandonment have occurred, placing children in boarding homes where neither parent can give proper care, and by doing a variety of things connected with child welfare. In 1948, the section supervised thirty-two children of whom the Friend is the official court-appointed custodian, co-operated with such agencies as the Polish Aid Society (in four cases) and the Children's Society (7); filed nine "neglect" complaints with the juvenile court; placed twenty-four children in boarding

99 Information supplied by the court.

${ }^{100} 1948$ REPORT, op. cit., p. 4.

101 Ibid., p. 7 . 
homes; investigated II 7 cases referred by the women's division of the police department and four cases referred by the city board of health, and made recommendations as a result of which the circuit court waived jurisdiction to the juvenile court in seventy-seven cases. ${ }^{102}$

Section concerned with reports and recommendations in pro confesso and guardian ad litem causes. In 1948, the Friend was appointed guardian ad litem in sixty-nine cases involving minors and mentally incompetent defendants. Attorneys from this section examined court files in 9,230 pro confesso divorce cases and notified attorneys of legal irregularities in certain cases. (When pleadings are correct, reports are filed from the section, upon receipt of which-and only upon such receipt-the assignment clerk places the cases on the docket for hearing.)

This section also files reports as to trust fund accounts for which the Friend acts as receiver. There are eighty such accounts in the office. Reports and recommendations were issued in thirty-seven cases which had been dismissed for lack of progress, and in which motions to reinstate were pending..$^{103}$

Section concerned with investigations and reports re children born out of wedlock. Under a recent statute, the Friend has taken over the work, formerly done by the social welfare authorities, of investigating and recommending support for illegitimate children. This includes ascertainment of the financial needs, verification of confinement expenses, gauging earning capacity of both parents in terms of the present responsibilities of each, and making recommendations comprising a plan for the child with recommendations as to the amount of support and the repayment of confinement expenses. All moneys are made payable to 
the Friend of the Court's office. The total case load of the section in 1948 was 3,995 cases; 209 new cases were opened during the year.

The grand total of investigations and reports by the entire investigation department, for 1948 , was $14,456 . .^{104}$

Complaint and enforcement department. This department was set up in 1945 as what was then called the "alimony complaint department," with the chief function of seeing that court orders for payment of alimony and sup. port are carried out. It has a director, twelve legal assistants, and fourteen stenographer-clerks. In I948, 35,393 complaints as to defaults in such payments were received4,582 more than in 1947. Action on such complaints is taken, by an assistant Friend, through a contempt citation, or, when necessary, by attachment of the body. The latter device can serve as the basis of extradition. In 1948, fortyfive extradition cases were referred to the prosecutor, and nine were completed, with a total collection of \$14,I93.19 in child support payments and $\$ 362.9 \mathrm{I}$ in costs. ${ }^{105}$

In 1948 , this department, because of the growth in its work and the widespread distress among wives and children under its supervision, instituted a mechanical "automatic checkup" system whereby each regular payment received in the cashier's department is automatically punched by electrical impulse on a card identifying the case. When two consecutive payments have been missed, the card of the defaulter is automatically caused to rise above the level of other cards in the same file drawer. Commencing in September, 1948, new divorce cases are checked once a month, by having a clerk run through the "automatic checkup" cards and removing those which are found above the surface. Where the arrearage is more than fifty dollars, contempt proceedings are instituted. 
In addition, the Friend is adding to the cases on "automatic checkup" all old cases in which contempt proceedings are taken. As of December 31, 1948, 2,332 cases were on "automatic checkup," as a result of which about thirty-two citations a week had resulted. Approximately 23 per cent of the cases on automatic check have resulted in contempt proceedings. ${ }^{106}$

This department also checks orders and decrees to verify and make certain of collecting service fees now payable to the Friend of the Court in partial reimbursement of its enforcement services. ${ }^{107}$ The cashier of the Friend of the Court collected $\$ 29,800$ in service fees, which was turned over to the general fund of Wayne County. ${ }^{108}$

Cashier's department. There is a cashier and fourteen assistants. All alimony and support money, as well as service fees, must be paid to the cashier of the Friend in order to be credited by the court as paid, so that accuracy of records may be maintained. Observation indicates that assistant Friends and judges sometimes accept money from defaulted defendants in courtrooms for later transfer to the cashier. In $1948, \$ 7,646,439.33$ was collected, a I 4 per cent increase over $1947 .{ }^{109}$

The work of the Friend as referee has already been described. ${ }^{110}$

Comment on extent of use of Friend of Court in Wayne County

Friday afternoons, in all eighteen courtrooms in the Circuit Court of Wayne County, are devoted to the disposition of contempt citations and other matters presented

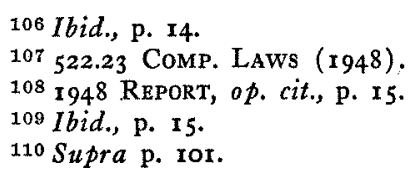


by assistant Friends of the Court, one or more of whom appears in each courtroom for this purpose. Most courtrooms are thus occupied from 2:00 P.M. until after $3: 30$ P.M. The presiding judge's courtroom, in which many of the "hardship" cases are brought, was busy until after four o'clock on several occasions during observation. On January $2 \mathrm{I}$, I949, a day selected at random, thirty cases were presented by an assistant Friend in the presiding judge's courtroom, and defendants were present and were questioned in twenty-one of these. Courtroom appearances by assistant Friends are not, of course, restricted to Friday.

The authority of the Friend to institute contempt proceedings for nonpayment of alimony has been upheld. ${ }^{111}$ Recommendations of the Friend do not deprive defendants of due process, and a defendant who refused to be questioned by the Friend is bound by his subsequent recommendations where accepted by the court. ${ }^{112}$

In effect, the enforcement of payment orders is no longer the responsibility of the wife or her attorney but has been taken over by the Friend of the Court. One result of systematic enforcement by the court's own administrative agency is that the public relief burden of the state, county, and city are considerably reduced.

The rapid growth of the Friend's office is another indication of the comparative seriousness and number, in the metropolis, of domestic relations cases. ${ }^{113}$ The interest and experience of the presiding judge and of the Friend in social problems is related to the present extensive use of the Wayne County Friend of the Court.

It is especially notable that the Friend and all assistant Friends, as well as department heads, are experienced lawyers.

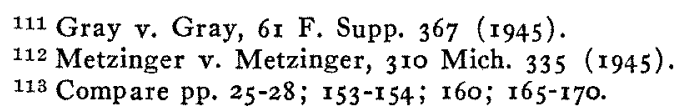


d. Court Agencies Dealing with Mental Problems

In addition to psychiatric services rendered in certain cases by state appointed sanity commissions, ${ }^{114}$ all but one ${ }^{115}$ of the courts operating in the city of Detroit have set up machinery for dealing with mental cases.

\section{In the Circuit Court of Wayne County}

The diagnostic services of psychiatrists in private practice as a part of the pre-sentence investigation is often obtained, at the court's request, by the probation officer. As an aid to his work in supervising persons convicted in municipal or justice courts of misdemeanors involving sex offenses, the probation officer can and often does refer probationers to psychiatrists for examination, upon court order. ${ }^{116}$

\section{In the Recorder's Court}

Authorized by statute in $1919,{ }^{117}$ a psychopathic clinic was established in I93 I. It consists of a director, an assistant director, two psychiatrists, a medical doctor, nine psychologists, and a small office staff of stenographic and clerical workers. Currently, the director is a psychologist, the assistant director a psychiatrist. The clinic examines, diagnoses, and submits written reports and recommendations on persons referred by recorder's court and traffic and ordinance court judges subsequent to determination of guilt but prior to sentence. These reports, like the pre-sentence investigation reports of the probation department, are used to guide the court in sentencing or determining conditions

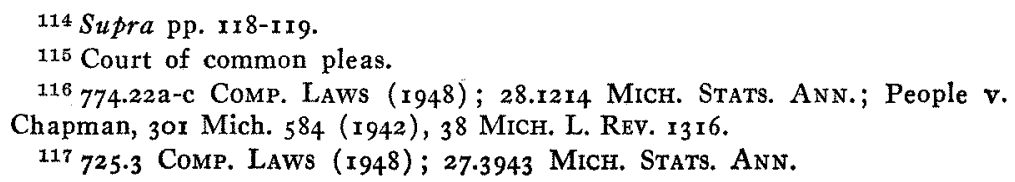


of probation of convicted offenders. Individual judges vary widely in their use of the services of the clinic. One or two of the ten judges now at recorder's court make no use of the clinic; several use it now and then; three or four use it very frequently. Recommendations of the clinic appear to be followed, the director estimates, in about 85 per cent of the cases on which the clinic reports.

Patients of the clinic are given physical examinations by the medical doctor and blood tests by a nurse from the Detroit board of health. If literate, they fill out case history forms. Each case is then examined by a psychologist, in a two-hour interview including a mental test and a case history. After the interview, the psychologist consults any outside sources of information relevant to the case-such as social agencies, hospitals, the police department, other courts, members of the family. When this information is assembled, the tests graded, and the conclusions formulated, the psychologist presents each case to one of the psychiatrists, who interviews the patient within the next few days in the light of the psychological information so organized.

At traffic court, referrals are made because of the nature of the offense, the patient's behavior, or because of his previous record. Referrals are sometimes made by the driver's license bureau of Detroit, which always refers every applicant who is known to have been committed to an institution for the mentally ill, or who presents a disoriented appearance or behavior pattern. Examinations of traffic patients include additional tests of neurological condition, intelligence, and visual and motor field tests covering speed and distance judgment, reaction time, and visualization. Road tests are sometimes used.

After the psychiatric interview, each case is discussed in staff meeting. These meetings, held daily, are attended by 
all the staff psychiatrists and psychologists. After discussion, a report to the judge on each case is dictated by one of the psychiatrists. This report, which is confidential, becomes part of the official case file. The work is completed on each case in seven days or less.

During $1947,1,924$ cases were referred to the clinic83 .or per cent of the patients were male; 65.66 per cent were colored; 89.7 I per cent were native-born; 35.12 per cent were Detroit-born. Types of offenses showing higher than average frequencies include assault and battery ( 10.99 per cent); sex charges (20.16 per cent); drunk (4.62 per cent); disturbing the peace (3.62 per cent); larcenies ( 9.65 per cent). Of the patients 27.09 per cent had no previous arrests prior to the offense resulting in reference to the clinic; 4 I. 38 per cent were single.

Furthermore, 5.70 per cent were found to be psychotic; 28 per cent mentally deficient without psychosis; 57.42 per cent showed some kind of psychopathy; 4.56 per cent showed other conditions; 3.42 per cent were normal.

And 6.54 per cent were committed to mental hospitals, .60 per cent were placed on observation, I 8.67 per cent were placed on probation, 39.38 per cent were sentenced to jail. ${ }^{118}$

In the Juvenile Court of Wayne County

The clinic for child study was until I 947 an unofficial community agency in the nature of a diagnostic service, financed by both public and private charitable agencies, specializing in the mental problems of children. In 1947 , it was recognized officially as a part of the juvenile court, which exercises authority over its work and pays the salaries of its full-time employees. The permanent director is a psychologist with specialized training in child psychology.

118 All figures on the clinic supplied by the clinic. 
The staff consists of psychiatrists who are staff members of various public hospitals located in the city of Detroit and who are assigned on a part-time basis to handle certain cases. These psychiatrists are currently made available by the chiefs of staff of the public hospitals, for certain days and hours during which they attend the clinic and where they handle cases assigned them by the director of the clinic. Once assigned to a case, the psychiatrist, except in extraordinary circumstances, remains on the case until the case is closed. Also on the staff of the clinic are psychologists and social workers. During observation, the clinic was in the first phase of its official relationship with the court, and the size of the staff together with the personnel composing it was subject to experiment as the case load and other factors indicated. At that time, however, there were three psychologists, five social workers and three clerks on the staff in addition to the director and six psychiatrists.

The clinic offers three types of service, as follows:

( I) Full study. A social worker (often a probation worker who is already well acquainted with the child) prepares a case history, a psychologist interviews and tests the child, and both present their findings to a psychiatrist. This psychiatrist sees the child once a week during contact. When the psychiatrist has obtained sufficient information to make an adequate diagnosis, a case conference is called, at which the director, the social worker, the psychologist, members of the family and other interested parties are present. Final report and recommendation is made to the juvenile judge in writing by the director on the basis of this case conference. The report and recommendation may also be made available to social agencies having an interest in the child. Two hundred forty-seven full studies were made during 1947 , as a result of which 1 I 2 children were given psychotherapeutic treatment, seventy-two children were 
committed to public institutions for dependent or delinquent children, nine children were placed for adoption, and fortyone children were noted as "closed cases," indicating unofficial or undisclosed disposition of a confidential nature. ${ }^{119}$

"The Clinic is oriented almost exclusively toward the future development of its patients," the director states in his 1947 report. "The 'offense' invariably loses its importance and usually disappears completely from the progress reports ... efforts are centered on the translation of . . . needs into corrective action. . . ."120

About half the clinic cases in 1947 were referred by the boys' probation department of the juvenile court, about one fourth by the girls' probation department, about one eighth by the police department. The remainder were referred by social agencies, by chaplains, by institutions or hospitals, whose requests for clinical service are granted as a courtesy.

(2) Short contact cases. The boys' vocational school of Wayne County requires, prior to admission, a showing that a boy is free from mental defects. Currently every boy committed by the juvenile court to the school is interviewed by a clinic psychologist, and his departmental case history is read and analyzed by a clinic social worker. A mental test is given, and from these materials a report is assembled by the director and sent to the school. Of 177 such cases handled during 1947 , almost one fourth (39) were known to the clinic from previous contacts.

(3) Adoption cases. During 1947 the clinic undertook to study the child and prospective adoptive parent "in order to support the Judge with adequate information regarding the suitability" of the proposed adoption in three cases. ${ }^{121}$

119 Annual Report of the Director of the Child Study Clinic (1947), pp. 5, 9-10.

120 Ibid., pp. 9-10.

121 lbid., p. ro. 
Comment on extent of use of the child study clinic at juvenile court. The Probate Court of Wayne County has jurisdiction over all petitions to commit mentally afflicted persons to institutions for the insane, including petitions concerning children. In practice, mental cases concerning children are handled at the probate court and not at the juvenile court. Although the probate court has no agency for the investigation or diagnosis of children alleged to be mentally afflicted, it is remarkable that no cases were referred to the child study clinic at juvenile court by the probate court during 1947 or 1948 . The register states that many such cases have already been screened, prior to the filing of petitions, by the clinic or some other agency with study facilities. This screening, however, is not under the control of the court, which, so far as observation disclosed, makes no attempt to conduct studies of its own or to inquire into the quality of pre-court studies.

\section{In the mental division of the Probate Court}

Although by statute any court of record, justice of the peace, or police justice may temporarily detain a person who appears to be insane, ${ }^{122}$ jurisdiction to determine the sanity of persons alleged insane and to commit them is in the probate court, ${ }^{123}$ except for proceedings incident to the prosecution of certain criminal offenders found to be mentally afflicted. ${ }^{124}$

Upon the petition for commitment of an alleged insane person, made by anyone with knowledge, the court is directed by statute to fix a day certain for the hearing, to appoint two reputable physicians to make an examination and to submit a certified report prior to the hearing, and to give

122 330.19 Comp. Laws (1948); 14.809 Mich. Stats. Ann.

123 330.20-2I Comp. Laws (1948); 14.8Io-I I Mich. Stats. Ann.

124 See supra pp. I18-119. 
personal notice to the defendant and any relatives. The court is, however, given authority to dispense with personal service and direct substituted service, in which case a guardian ad litem must be appointed.

An inquest consisting of full investigation of the facts as required by the statute is mandatory. ${ }^{125}$ The court may detain the alleged insane person pending the hearing. ${ }^{126}$ The probate court may also commit drug addicts and chronic alcoholics under the same procedure, with the important exception that petitions for such cases must be filed by the legally appointed guardians of those alleged to be addicts. ${ }^{127}$

Where the committed person is without funds or relatives required to support him, the county is liable for a year, at the end of which the state assumes financial responsibility. ${ }^{128}$

The mental division of the probate court, though technically under the administrative authority of the register, operates as a self-contained and separate unit. The staff consists of a director, an assistant, three typists, five process servers, and one matron. No member of the staff is a lawyer, a psychologist, a psychiatrist, or a medical doctor. The petitioner in any mental case is sent to the mental division, where he is interviewed by the head or the assistant and helped to fill out a printed petition. After this is signed and certified, the head assigns a process server to serve the summons and causes the matter to be set down for hearing. The mental docket is set, unlike other probate court cases, by the head of the mental division, so that he may be sure that hearings take place within the statutory thirty days within which patients may be temporarily detained in public or private hospitals. The doctors are then notified of their appointment and provided with printed

1.25330 .21 Comp. Laws (1948); I4.81 I Mich. Stats. Ann.

126 Loc. cit.

127 703.1 Comp. LaWs (1948); 27.3178 (201) Mich. Stats. Ann.

128 330.21 Comp. LaWs (1948); r4.811 Mrch. Stats. Ann. 
forms for their certificates. It is the practice for doctors to go where the patients are in order to make the examinations, and their reports, after being filed, are presented at the hearing by the head of the mental division without the doctors being present.

In arranging for hearings of mental cases, the head talks by telephone several times daily with the receptionists in the psychopathic wards of Detroit Receiving Hospital, the city public hospital, Wayne County General Hospital, the county public hospital, and all state institutions for the mentally afficted. Since all these institutions are very crowded, the disposition of mental cases calls for the closest co-operation between hospital and court personnel. Hearings are therefore set down in the order dictated by the urgency of the demand for beds at the county and city hospitals.

Since the county relief authorities are financially responsible for indigent mental patients throughout the county, and since the statute permits the court to require them to investigate and report on the financial status of persons committed to public mental institutions, a case worker employed by the county department of social welfare is assigned by that agency to each mental case. There are seven such case workers, who investigate the financial circumstances only, and who attend hearings for the purpose of advising the court whether persons found to be insane shall be committed as public charges or not.

Professional case workers employed by both the city and county public hospitals act as petitioners in cases involving indigent patients in the psychopathic wards, where the workers interview the patients. Having executed petitions, they later appear in court to testify from their interview notes with regard to the mental condition of the patients. Each of these workers spends considerable time in court; 
there are usually three or four of them in each courtroom when mental cases are being tried. Often the testimony of these workers is the only proof of the mental condition of the person alleged to be insane. In order to facilitate the hearing of these cases, the doctor in charge of the ward routinely certifies that the presence of the patient at the hearing is improper and unsafe.

Thus, the courtroom presentation of a mental case is made in somewhat the following manner: the head of the mental division, standing at the side of the judge, calls the case and gives the judge a brief oral résume of the case. ${ }^{129}$ Any members of the family who appear are given an opportunity to testify if they wish to do so. Questions may be asked by the judge. In most of the cases, the petitioner is a hospital case worker, testifying from notes as to the mental condition of the patient whom she has interviewed in the hospital. She may and often does include testimony regarding the reason for hospitalization. At the conclusion of this testimony, the judge inquires about the patient's financial condition from the case worker who has investigated that. Commitment or dismissal then takes place. The patient is seldom present at the hearing.

When the appointed doctors disagree, it becomes necessary for the court to obtain other doctors further to advise the court. Each of the five judges appoints a list of about ten doctors from which the head assigns two to each case pending before the respective judges. Most of the listed doctors are not psychiatrists. Doctors are seldom present at hearings.

The procedure in such a case was witnessed on Thursday, April 8, I948. ${ }^{130}$ In that case, the patient was a woman who had been hospitalized at the Ypsilanti mental hospital pend-

129 After observation was complete, the head of the mental division advised the writer that this practice has been discontinued.

${ }^{130}$ See Appendix C. 
ing the hearing. Of the doctors originally appointed by the court, one reported her medically insane, the other reported her medically sane. The patient came in with her husband (the petitioner) and her sister, but sat alone several seats behind them. Two doctors, appointed by the court to give supplemental advice, were introduced to the husband and sister by a court employee. After talking with the husband and sister for ten minutes, the doctors went to the patient and talked with her for between four and five minutes. During this period, the judge had been waiting. The doctors returned to a place beside the husband, and the head of the mental division, at a signal from the judge, commenced the presentation of the case.

The husband testified that his wife wanted to sell some furniture, that she neglected herself and her children, and that she complained about her neighbors. The sister testified that the husband's testimony was true, that he was a good husband, and that the patient had done things that were "not right."

One doctor testified that he had examined the patient just previous to testifying and that there was no question in his mind that the patient has "a psychosis which probably is of a paranoid type and she should be hospitalized."

The other doctor testified that he was a psychiatrist, that he had examined the patient just before testifying, and that "she has a total lack of insight," "is very sick from a psychiatric standpoint," and "is in need of prolonged hospitalization" for "schyzophrenia [sic], paranoid type."

The patient, having been sworn, testified at some length to the effect that she was tired out from caring for two school-age children and doing all the housework without help. The heavy work, such as laundry and cleaning, had become too much for her, she said. "The only thing wrong with me is I need a little rest." She pointed out that she was 
not likely to get it in the mental hospital, where, while on temporary detention, she had been waiting on six hundred other patients at meals for two weeks.

The judge, though finding himself impressed with her testimony, committed her to Ypsilanti as a public charge. The complete transcript of this case is included as Appendix C. Present courtroom procedures are much like those described at length in a study of courtroom commitment procedures published in the Thirteenth Annual Report of the Judicial Council of Michigan.

The mental division disposed of 2,694 mental petitions in 1947. In 1945, the total was 1,993 and in 1946, 2,716. In 1948 , the total had gone above the entire 1947 total by more than 500 , as of October of $1948 .{ }^{131}$ The increasing size of the case load, and the increasing pressure from Receiving Hospital and Wayne County General Hospital is such as to cause the gravest concern to the head of the mental division and to the judges themselves. The County of Wayne has recently established a county mental hygiene clinic, which by providing a publicly financed out-patient clinic in the city of Detroit, will probably reduce the need for commitment as a means of obtaining psychiatric care.

Although a statute ${ }^{132}$ requires the probate court to fix a hearing for adjudication of restoration of sanity whenever notified, by the superintendent of a mental institution, that a committed patient has been released as cured, in fact the present procedures provide for adjudication of restoration of sanity only when a person interested in a particular patient files a petition. As a result, a large number of notices of release as cured, which are filed with the Probate Court of Wayne County by the medical superintendents of mental hospitals, are simply left on file and no adjudication takes place. 
Although recent amendments of the statutes provide for an adjudication of restoration of sanity upon certification of the medical superintendent and a member of his medical staff, this does not preclude the use, as before, of two physicians appointed by the court for the purpose of advising with regard to restoration. ${ }^{133}$ It would simplify the problems of the court and serve the rights of restored patients to follow the suggestion, made in the judicial council study and published in its Thirteenth Annual Report, that the medical superintendent's certificate of discharge, when filed with the probate court, shall operate as a restoration of sanity without the need for further court proceedings. There were 240 persons declared restored to sanity by the Probate Court of Wayne County in 1947.

During 1947, fifty were committed as chronic alcoholics, one as a drug addict, $\mathrm{I}, 4 \mathrm{I} 7$ committed as insane.

\section{Section 5. Size of Court Staffs in Detrott}

The total number of persons employed in various capacities by each of the courts operating in Detroit is set forth in Table XXI. In this table, clerical employees of administrative agencies, if they are controlled by the head of the administrative agency rather than by the administrative officer of the court, are included in the classification "administrative."

The size and departmentalization of the personnel of these courts is entirely unlike that encountered outside the city of Detroit, and sets these courts apart. The number of people present in a courtroom in Detroit, for instance, imposes problems such as controlling the noise and confusion necessarily incident to the movement and communication of so many people. Traffic noises from the streets, in volume and variety unlike anything outside the metropolis,

${ }^{133}$ Loc. cit. 
ORGANIZATION : ADMINISTRATIVE PERSONNEL 193

\section{TABLE XXI}

Personnel of Courts Operating in Detroit (1948)

Steno-

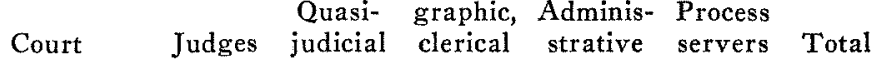

$\begin{array}{lllllll}\text { Circuit } \ldots \ldots \ldots & \text { I } 8 & 5 & 96 & \text { I2 I } & \ldots & 240\end{array}$

Recorder's .... Io $\quad$ I $\quad 49 \quad 70 \quad \ldots \quad$ 130

$\begin{array}{lllllll}\text { Traffic } \ldots \ldots \ldots & 2 & 5 & 143 & \ldots & \ldots & 150\end{array}$

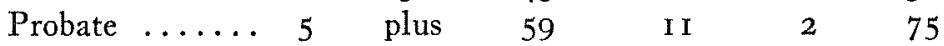

$\begin{array}{lllllll}\text { Juvenile } \ldots \ldots & \text { I } & 6 & 96 & 73 & \ldots & 176\end{array}$

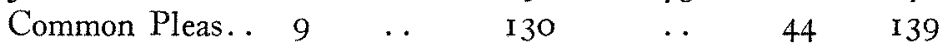

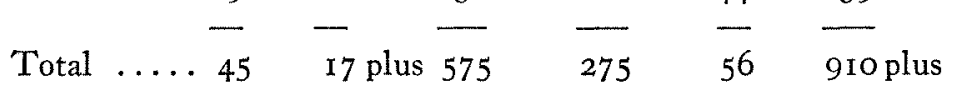

intensify the problem of preserving sufficient decorum to enable the judge to hear counsel and witnesses, as well as to preserve an atmosphere commensurate with the dignity of judicial proceedings. 


\section{Machinery for Handling Dockets and Disposition of Case Load}

\section{Section i. Machinery for Handling Dockets at Circuit Court}

a. Relation of Pre-Trial Conference to Docket

$7 \mathrm{HE}$ use of the pre-trial conference in all but criminal 1 cases in the Circuit Court of Wayne County is of considerable importance as a protection against delay in the disposition of cases, for it screens out of the docket those matters which can be settled without trial. A comparison of the condition of the Circuit Court of Wayne County docket at the end of the year 1933, before the institution of the compulsory pre-trial conference, and at the end of 1934, during which year the conference was made a regular part of the machinery, showed a gain of two months and twenty-four days in law cases, and of two months in chancery cases, with respect to the time elapsing between issue and coming to trial of the oldest cases disposed of during each year. These figures are given in the Fifth Annual Report of the Judicial Council of Michigan, which further noted that the improvement took place despite a large decrease in assistance received from outside judges. ${ }^{1}$

Noted in subsequent reports of the council is the fact that in 1935,40 per cent of the cases ready for trial were finally disposed of on the pre-trial hearing; that between I935 and 1939, an average of 52.7 per cent were so dis-

Isupra p. I1. 
posed of; in $1940,64.2$ per cent; in I94I, 54.3 per cent; in $1942,61.9$ per cent; in $1943,52.3$ per cent; in $1944,54.95$ per cent; in $1946,73.27$ per cent; in $1947,77.21$ per cent; in I948, 76.06 per cent. "Since the Wayne circuit court is the only court in the state which employs pre-trial procedure in all cases, it seems fair to conclude that the small proportion of cases tried is due in substantial part to the use of this device." ${ }^{\prime 2}$ Pre-trial procedure is not used in criminal cases.

On April 22, I949, the presiding judge of the Circuit Court of Wayne County, selecting a group of cases at random, reported that for the first seven court days of April a total of seventy cases came before the chancery pre-trial docket, of which sixty-three were finally disposed of at pre-trial conference and seven were passed on to the trial docket. The judge estimates that this was a total saving of sixty-eight days of trial judges' time over the time which they would have spent "if the cases had been assigned directly to the judge in the old-fashioned way."

\section{b. Assignment of Cases}

The progress of cases in this court is under the direct control of the presiding judge. The system whereby cases move toward trial may be briefly outlined as follows :

\section{Trial calendar}

From time to time, as directed by the presiding judge, the county clerk prepares a calendar of cases ready for trial, from cases fully at issue in which a trial praecipe has been filed with the clerk. It consists of such number of cases

2 Seventeenth Annual Report of the Judicial Council of Michigan: Judicial Statistics for the Year 1946 (Lansing, Michigan: October, 1947), p. 22.

${ }^{3}$ Letter from the presiding judge, dated April 22, 1949, to Mr. Will Shafroth, administrative officer of the United States courts. 
as are required by the presiding judge, numbered consecutively in the order filed with the clerk. From this trial calendar, when delivered to the presiding judge by the clerk, cases are moved forward onto various dockets for assignment as hereinafter described. ${ }^{4}$

\section{No progress calendar}

From time to time, as directed by the presiding judge, the county clerk prepares a separate calendar of causes in which no progress has been made for a year. After this list has been received by the presiding judge, it is published in the official newspaper. ${ }^{5}$

Motions concerning calendar are heard only by the presiding judge, and are required to be determined by an order of the presiding judge, notice of which is given to the assignment clerk. No cause can be removed from its position on the calendar except by such an order of the presiding judge. ${ }^{6}$ A cause which has been moved ahead of its original calendar position is described as "advanced."

\section{Special divisions and dockets}

There are several specialized divisions of the court. Cases falling within any of the following groups are listed into dockets out of the current calendar, for attention by each of the divisions, as follows :

I. The pre-trial and reference docket is called daily before the presiding judge. It includes all chancery cases, which are placed on this docket for pre-trial hearing some time before they reach the trial call. ${ }^{7}$

2. The appeal docket is called at Io:00 A.M. daily before

4 Rules of the Circuit Court for the Third Judicial Crrcuit of MichiGan (WaYne CoUnTy), revised to April $x$, 1948, part I, no. 3 (a), p. 2.

5 Ibid., part I, no. 3 (b), p. 2.

${ }^{6}$ Ibid., part I, no. 4 (b)-(c), p. 3 .

' Ibid, part II, no. I, p. 18. 
the presiding judge. It includes all appeals from subordinate tribunals in the circuit, which are placed on this docket immediately after return reaches the clerk, so that trial may be expedited. ${ }^{8}$

3. The no progress docket, consisting of as many cases from the no progress calendar as can be assimilated readily during the oncoming term, is called monthly before the presiding judge following published notice. Such a case may be saved if, within five days from the calling of the docket, a praecipe, motion, and affidavit, together with proof of service of the motion, are filed with the county clerk, and if the presiding judge finds the showing sufficient to support an order to reinstate the case. ${ }^{9}$

4. The law pre-trial and conciliation docket consists of law cases which are not yet reached for trial but which are ready for pre-trial hearing. This docket is called daily before the law pre-trial judge. ${ }^{10}$

5. The pro confesso docket consists of uncontested divorce cases. They are praeciped for trial with the county clerk, but receive special handling in that they are not placed on the trial call until after the Friend of the Court has approved the pleadings and filed his report. ${ }^{11}$

\section{Calls}

The assignment clerk, whose office adjoins that of the presiding judge and whose work is under that judge's close daily supervision, assembles a law call and a chancery call each term-i.e., each month. Cases on each of these calls are numbered in the order in which they are taken from the calendar, beginning with the number "one" each term. The calls are published in an official newspaper designated

\footnotetext{
8 Ibid., part II, no. 2 , p. 18.

${ }^{9}$ Ibid., part II, no. 3, pp. x8-r9.

10 Ibid., part II, no. 4, pp. I9-20.

11. Ibid., part II, no. 5, pp. 20-21.
} 
by the court. Before a case reaches number 60 on the law call or number to on the chancery call, one adjournment may be had by consent, except in advanced or no progress cases, upon application to the presiding judge. Additional adjournments may be had only for cause shown by affidavit on motion. Once these numbers are reached, adjournment will not be granted except for causes beyond the control of litigants, arising after the case has reached such number. ${ }^{12}$

The monthly law call and the monthly chancery call are subdivided by the assignment clerk into daily calls, each of which is published in an official newspaper ten days in advance of the day when the call will be reached for trial. Two or three days before each case is reached, attorneys are notified by telephone by a member of the staff of the assignment clerk.

\section{Assignment}

Attorneys and litigants report directly to the office of the assignment clerk, who assigns each case as it is reached on the call. The presiding judge, who has checked each day's call with the assignment clerk, will have designated the judge to which each case is to be assigned. The clerk, therefore, is able to direct each attorney and litigant to the courtroom of the judge who will conduct the trial. When each judge finishes trying a case, he so reports to the assignment clerk. Emergencies or other problems in assignment are referred directly to the presiding judge.

Each judge fully disposes of all cases assigned him, retaining exclusive jurisdiction to finally adjudicate, including new trial, retrial, and rehearing. Subsequent proceedings after a divorce decree are heard by the judge who entered the decree. ${ }^{13}$ 
Criminal cases take precedence in assignment. The presiding judge arraigns all criminal defendants.

Section 2. Machinery for Handling Dockets at Recorder's COURT

\section{a. Preliminary Examinations}

Preliminary examinations in felony cases are scheduled for hearing by the docket clerk in the order in which defendants are arraigned on warrants. One of the purposes of this arraignment, at which a judge assigned to the misdemeanor division informs each defendant of the nature of the pending charge, fixes or disallows bail, and enters each defendant's plea on the record, is to ascertain whether an examination is waived or demanded by each defendant. Preliminary examinations where demanded are conducted by a judge assigned to this duty for the current month.

\section{b. Misdemeanors}

Misdemeanor cases go before the judge or judges assigned to the trial of misdemeanor cases for the current month. Prior to the opening of court, a police officer and a judge go over the arrest tickets of all persons held for trial that day. At that time, the judge signs complaints and warrants, on printed forms obtained from the warrant clerk by the police officer, for all persons who are to be held for trial. Warrants for persons not in custody are also executed by the misdemeanor judge at this point. ${ }^{14}$

When court opens, persons held for court disposition are brought before the bench in open court and tried or otherwise disposed of. Each day's misdemeanor cases are disposed of as they accumulate. Since the great majority of defendants are in custody, the responsibility for the move-

14 Statutes and Rules for the Recorder's Court (r938), rule r8, p. rog. 
ment of the cases is on the police. There is no serious observable problem of delay in misdemeanor cases, because the jails are so overcrowded in Detroit that the police are strongly motivated to expedite the trials.

\section{c. Felonies}

\section{Presiding judge}

The presiding judge, in addition to hearing miscellaneous motions and arraigning felony defendants on information, distributes the day's felony cases to various courtrooms for trial. Ordinarily six judges are assigned each month to the felony division-some to conduct jury trials, the others to conduct jury waiver trials. Each of these, unless he has a case in progress which has carried over from the previous day, awaits assignment from the presiding judge, who calls the current felony docket each day and sees to it that each case receives such attention as is appropriate at the stage it has then reached.

\section{Necessary steps preliminary to official docketing}

Before a felony case can be docketed for trial, it must go through several preliminary steps in the recorder's court. Briefly, these steps include:

I. A felony complaint is signed in the prosecutor's office;

2. The complaint is sent to recorder's court together with the prosecutor's recommendation for issuance of a warrant;

3. The clerk sets up the file and delivers it with the recommendation to the warrant clerk, who draws a warrant;

4. The warrant is signed by the examining magistrate, and served by the police;

5. After service, the defendant is arraigned on the warrant, and is released on bail or remanded to custody; 
6. Examination is waived or held;

7. The examining magistrate decides whether to bind over the defendant;

8. The warrant clerk draws the "justice's return," which is the document officially evidencing the binding over of each defendant held for trial, and this is signed by the examining magistrate. The entire file is then sent to the prosecutor's office;

9. The prosecutor draws an information in each case, and returns the file to the clerk of the recorder's court;

Io. The presiding judge arraigns each defendant on the information-that is, the felony division takes official cognizance of the case, the judge informs the defendant of the nature of the charge against him, bail is fixed or denied, and the plea of the defendant is officially entered.

From this point on, jail and bail cases are handled separately.

\section{Assembling of docket by docket clerk}

When step nine, above, has occurred, each file is placed by a deputy clerk upon the desk of the docket clerk, who sets up a docket for each day. Dockets are arranged about three weeks in advance, in somewhat the following manner: of a total of the approximately twenty-three cases which made up a full day's docket during the period of observation, about half were bail cases. These cases are officially docketed by name and file number of case, three weeks in advance of trial. In planning the distribution of jail cases, however, although the number of cases of each type is decided on at this date, the actual cases to be tried are not selected until about a week before the actual call of the docket. That is, the docket clerk, when making up a docket three weeks in advance, will determine finally that on that day one murder case, five robbery armed cases, three sex 
cases, and so on, will be tried. The decision as to which murder case, which robbery cases, and so on, will be tried on that day will be made shortly before the trial. This is done in order that the docket may contain no preponderance of any one kind of case, and in order that individual cases may be selected in such a manner as to result in the trial of persons who have been in custody the longest period of time, so as to keep the jail population as low as possible. Preselection of the types of jail cases by the docket clerk is made on the basis of the backlog of untried cases of various types.

When cases are officially docketed, the docket is published. Attorneys and bondsmen are notified by telephone concerning the date of trial, and witnesses are subpoenaed.

\section{Daily distribution of docket by presiding judge}

Each morning, the docket clerk takes all the files for the day's felony call to the presiding judge's courtroom, and stands at that judge's elbow. As each case is called, the docket clerk advises the judge of the current status of the case, and the case is assigned for trial, adjourned, a guilty plea is accepted, or other action taken. All guilty pleas must be accepted by the presiding judge, ${ }^{15}$ and he is required to hear all motions for nolle prosequi. ${ }^{16}$ If a case has been assigned to a judge for trial, and prior to the swearing of a jury or the filing of a waiver of jury trial the defendant offers a plea of guilty to a lesser included offense, the case is sent back to the presiding judge. Adjournments are the exclusive province of the presiding judge. ${ }^{17}$ When any motion is granted concerning the docket, notice of his order is given to the docket clerk. No cause can be moved from its docket position unless by order of the presiding judge. ${ }^{18}$

15 Ibid., rule 9, p. Io5.

${ }^{16}$ Ibid, rule 22 , p. III.

17 Ibid., rule $2 \mathrm{r}$, and see rule 25 , pp. r ro-rix.

18 Ibid., rule 9, p. 105. 
The docket clerk checks the felony files each time they are subjected to any official court action. $\mathrm{He}$ is the only officer of the court who maintains continuous contact with all cases throughout their progress.

\section{Maneuvering for or away from a particular judge}

Under the present rotation system whereby the presiding judge at recorder's court serves one month only, the possibility of corrupt prearrangement, by attorneys, for trials before certain judges is regarded as eliminated. Under the present assignment system, nevertheless, there is some opportunity for manipulation. Knowing which judges are on fixed assignments in any given month, a lawyer knows that his case will be assigned to some one of, say, three judges. When his case is called, he can plead his client guilty before the presiding judge, or he can waive a jury and go before one of the judges assigned to nonjury cases, or he can ask for an adjournment, hoping for a more favorable presentation of judicial personalities the next time the case is called. Again, if he fears that the presiding judge will be more harsh in sentencing a certain kind of offender than some one of the trial judges, he can go before the trial judge, proceed just far enough so that jeopardy attaches, and then plead guilty. ${ }^{19}$

\section{Section 3. Machinery for Handling Dockets at Traffic and Ordinance Court}

So much of this case load is handled by the pre-court payment of fines that the chief deputy clerk finds the arrangement of docket not a complex problem. Felony cases are sent to one of the two judges, traffic ordinance cases to certain

19 Jeopardy attaches when any evidence has been introduced. Waiting until this point accomplishes the purpose of preventing the operation of rule 22 , which requires that guilty pleas must be heard by the presiding judge except where the defendant changes his plea during the trial. 
referees, miscellaneous ordinance cases to other referees. Dockets are assembled by deputy clerks in accordance with the schedules of the police officers who are to testify, so as to permit them to spend certain days in court and other days on their tours of duty.

\section{Section 4. Machinery for Handling Dockets at Probate Court}

In the probate court, the register is responsible for the orderly disposition of cases, except that the head of the mental division assembles the dockets of mental cases. Cases are assigned in groups, by subject matter. Cases are assigned from the register's office from schedules prepared by the court clerks. Each day an employee of the register presents to each judge's courtroom clerk a sheet of paper. The courtroom clerk, who takes care of publication dates and dates of hearing for his judge, writes down on this paper the names, file numbers, and kinds of hearing scheduled for the judge for that day. The memoranda thus obtained for all five judges are photostated, and the resulting material becomes the official day's schedule. On April 7, 1948, for instance, the schedule shows that one judge had a docket consisting of eighteen feeble-minded cases, another a miscellaneous estates docket of twenty-six cases such as annual accountings, petitions to admit wills to probate, and the like. A third judge had nineteen miscellaneous estates matters, a fourth had twenty-seven habitual drunkards, another forty-one estates claims and a fifth seventeen estates claims. The day was chosen at random.

Section 5. Machinery for Handling Dockets at Juvenile Court

Case dockets are arranged in the chief clerk's office. Unofficial hearings are arranged by each department. 
Section 6. Machinery for Handling Dockets at Court of Common Pleas

When files on incoming cases have been set up by employees of the clerk, the files are delivered to docket clerks. From the files, the docket clerks prepare the call, or list of all pending cases, distribute them into daily calls consisting of a group of variegated cases to be disposed of on each day, and send each daily call list to the official newspaper for publication. This daily call is also posted, and trial notices are mailed to the parties. In addition, attorneys may arrange to be notified by telephone as to the day set for trial of their cases.

The docket clerks also prepare a daily court schedule by means of which the cases on the daily call are tentatively distributed among the nine judges several days in advance of trial. On the morning of each day, the presiding judge and a deputy clerk open court in a small, auditorium-like room to which all persons having business on the daily call for that day report at 9:00 A.M. As each case is called, the presiding judge makes a final assignment of the case to a specific courtroom judge, and the parties who have answered the call report to that courtroom.

\section{Section 7. Age of Cases}

\section{a. Circuit Court}

\section{Law and chancery cases}

As of January I, r 949, the interval between the date when the oldest cases were noticed as ready for trial and the date of the actual trial were as follows:

Law cases: I 8 months and I 5 days

Chancery cases: 18 months and Io days ${ }^{20}$

20 Nineteenth Annual Report of the Judicial Council of Michigan: Judicial Statistics for THE Year 1948 (August, 1949), table X, p. 53. 
Part of the assignment clerk's duty is to carry on a continuing check of cases to be dismissed for no progress. In addition, there is in November of each year an actual case count of pending cases which is also useful in checking old cases.

\section{Criminal cases}

The jail population of the Wayne County jail as reported by the turnkey for the week ending July Io, 1948, a date chosen at random, contained a total of sixty-six prisoners chargeable to the Circuit Court of Wayne County. Of these,

\begin{tabular}{|c|c|c|c|c|c|}
\hline 17 & $"$ & $"$ & I I & 30 & 6 \\
\hline 19 & " & " & 3 I & 60 & " \\
\hline 6 & " & " & $6 \mathrm{I}$ & 90 & " \\
\hline 3 & " & " & $9 \mathrm{I}$ & I 20 & " \\
\hline & " & 6 & $\mathrm{I} 5 \mathrm{I}$ & I 80 & ، \\
\hline
\end{tabular}

The median time in custody of this group was between thirty-one and sixty days. Forty-two, or 63.6 per cent, had spent two months or less in custody; fifty-two, or 78.7 per cent, had spent three months or less in custody; fourteen, or 2 r.3 per cent, had spent more than three months in custody. Thirty-one, or 47 per cent, had spent less than thirty days in custody. ${ }^{21}$

The criminal cases of the circuit court are subject to the check of a written inventory once a year, which shows the exact status of each pending case. Also, each week the presiding judge goes over the current jail list supplied by the turnkey, and inquires as to the progress of those cases

2x The same jail population report showed eight prisoners chargeable to traffic court, none of whom had been in custody longer than two weeks, fourteen prisoners chargeable to various justice courts in the county for whom the median interval in custody was between two weeks and a month. See also infra pp. 207-208. 
in which the defendants have been lodged in jail for an unusually long period of time. Where the reasons for delay are unsatisfactory to the presiding judge, the prosecuting attorney is required by him to proceed forthwith to the trial of the case.

\section{b. Recorder's Court}

\section{Jail cases}

The jail population of the Wayne County jail for the week ending April 3, 1948, chosen at random, included 327 prisoners chargeable to recorder's court-i.e., awaiting trial or sentence there. The median time spent in custody by members of this group was between sixteen and thirty days. One hundred and seventy, or 51.99 per cent, had been in custody thirty days or less; 239 , or 73.09 per cent, had been in custody sixty days or less; 287 , or 87.77 per cent, had been in custody ninety days or less; forty, or 12.2 per cent, had been in custody ninety-one days or more; ten, or 3 per cent, had been in custody six months or more. Of that group of ten, five were charged with murder, one with robbery armed, one with breaking and entering, one with larceny, one with felonious assault, and one with gross indecency.

The jail population of the Wayne County jail for the week ending July IO, 1948, also chosen at random, chargeable to the recorder's court, included 265 prisoners, for whom the median time spent in custody was between eleven and thirty days. Fifty-five, or $\mathbf{1} 3.2$ per cent, had been in custody ten days or less; I4I, or 53.2 per cent, had been in custody thirty days or less; 209 , or 75 per cent, had been in custody sixty days or less; 224 , or 84.5 per cent, had been in custody ninety days or less; forty-one, or 15.5 per cent, had been in custody ninety-one days or more; six, or 2 per cent, had been in custody more than six months. Of this 
group of six, five were held on charges of murder, one on a charge of robbery armed.

The writer inspected the files of the sixteen prisoners noted in both the above groups as having been detained for six months or longer. Ten of the prisoners were charged with murder; in such cases, the filing of a report by a sanity commission must always precede final docketing for trial. Such commissions are appointed after arraignment on information. Typical of the interval between arraignment on information and filing of the sanity commission reports are these: in one case, fifty-five days; in a second, fifty days; in a third, thirty-one. In two cases, delay had been caused by the granting of a convicted defendant's motion, in each case, for a new trial. Under a recorder's court rule, a new trial must be conducted by the same judge who conducted the original trial $;^{22}$ in both the cases under discussion, the original trial judge was prevented by assignment to grand jury duty from conducting trials for a long period of time. Two cases showed repeated adjournments, but the files did not show whether these adjournments were requested by the prosecution or by the defendants' counsel. In some observed cases, where the defendant was charged with several offenses, prosecutor and defense counsel agreed to repeated adjournments of one matter pending final disposition of one or more of the other matters involving the same defendant.

\section{Bail cases}

On November 23, 1948, the records in the office of the clerk of the recorder's court ${ }^{23}$ showed a group of 2 I 4 felony cases in which defendants were arraigned on warrants after January 3, 1948. Ninety-six jail cases and sixteen cases not

22 Rules, op. cit., rule 24 .

${ }^{23}$ See supra p. 143 and chap. V, n. 34 . 
yet finally disposed of were eliminated, leaving a group of IO2 bail cases representing 105 individual defendants. These cases yielded the following data with respect to duration:

\section{Over-all duration:}

Twelve defendants were disposed of in a total of between $\mathrm{I}$ and 7 days; 5 between 8 and $\mathrm{I} 4$ days; ro between $\mathrm{I}$ and 2 months; 19 between 2 and 3 months; 8 between 3 and 4 months; 17 between 4 and 5 months; 13 between 5 and 6 months; 6 between 6 and 7 months; 3 between 8 and 9 months; 4 between 9 and Io months. Median duration of the group was between 2 and 3 months.

\section{Interval between arrest ${ }^{24}$ and disposition without trial:}

Thirty-two defendants were disposed of without trial: 6 at arraignment on warrant, $\mathrm{I} 7$ at preliminary examination, 9 at arraignment on information. Median duration of this group was between $\mathrm{I}$ and 7 days.

\section{Interval between arrest ${ }^{24}$ and final disposition at trial:}

Ten defendants were disposed of at trial by dismissal; 6 found not guilty by court; 2 found not guilty by jury; I found insane; 33 found guilty by court; 18 pled guilty at trial. The median duration of this group was between 3 and 6 months.

${ }^{24}$ The date of arraignment on the warrant was taken as the time at which the court's responsibility begins. This is in fact the date at which the court records begin. Most defendants are arrested prior to issuance of a warrant. In the vast majority of cases, the arraignment on the warrant takes place on the same day as the arrest. It is possible that in some cases the arraignment on the warrant took place the following day (as where the arrest took place after the misdemeanor division judge assigned to arraignments on warrants had finished work for the day). For the purposes of this section, however, it is assumed that the time of arrest is the same as that of the time of arraignment on the warrant, and the word "arrest" is equivalent, in this group of cases, to the date noted on the court records as the date of arraignment on the warrant. In this, the writer follows a recent study. See John B. Waite, "Slow Justice' in Michigan," 27 Michigan State Bar Journal, July, I948, I7-20, at I8-I9. 
Further analysis of the group broke down the intervals as follows :

I. Interval between arrest ${ }^{24}$ and preliminary examination. Over half ( sixty-two) waived preliminary examination. The median interval for the remaining fifty-eight was between one and two weeks.

2. Interval between examination and arraignment on information. Thirty-three examined defendants in the group were later arraigned on information, the median interval being between thirty and thirty-five days.

3. Interval between arraignment on information and trial. Seventy-three defendants in the group went to trial. The median interval for the group was between two and three months.

4. Interval between trial and sentence. Fifty-one defendants in the group were found guilty. The median time between trial and sentence was between one and seven days.

On the same day, November 23, 1948, another group of felony bail cases, formed by subtracting forty-one jail cases and fifteen undisposed-of cases from roo cases in which defendants were arraigned on warrants on and after July I 7, 1948 (leaving a group of thirty-eight cases representing forty-one defendants), yielded the following data with respect to duration:

\section{Over-all duration:}

Median: between two and three months.

2. Interval between arrest and disposition without trial: Median: between two weeks and one month.

3. Interval between arrest and final disposition at or after trial:

Median: three months. 
The internal intervals in this second group displayed a median interval of between one and two weeks between arraignment on warrant and examination for nineteen defendants who were examined; a median interval of between two weeks and a month between examination and arraignment on information for twenty-three defendants so arraigned; a median interval of two months between arraignment on information and trial for twenty-five defendants who went to trial; and a median interval of between two weeks and one month between trial and sentence for the twenty-five defendants who were found guilty at trial.

There has been considerable recent controversy about the age of recorder's court cases. A member of the faculty of the University of Michigan Law School presented a statistical study of the age of these cases in the July, I 948, issue of the Michigan State Bar Journal. His article was discussed by a member of the recorder's court bench in an article in the succeeding issue of the journal. ${ }^{25}$

25 Ibid. A group of cases was assembled by selecting 125 felony cases a month, in the order they appeared on the court calendar, for every third month over the years 1936-1946. The month of beginning was rotated each year. About one case in every six was covered. All gambling and liquor cases were excluded. Jail and bail cases were not separated.

Professor Waite found the median total duration of his group of cases, from arrest to final disposition, for each year of the decade covered. For instance, in 1944 , the median was sixty-one days; in 1945 , seventy-eight days; in 1946, fifty-nine days. The data for $x 946$ were further broken down to show the interval required from each procedural step to the next. In 25 per cent of the cases, preliminary examination was waived; in 50 per cent of the cases the examination took place within one day from the arrest; in 75 per cent of the cases examination took place within seven days after arrest. Information was filed within seven days after examination in 25 per cent of the cases, within eleven days thereafter in 50 per cent, and within sixteen days thereafter in 75 per cent of the cases. Arraignment on information took place within one day after filing of information in 25 per cent of the cases, within three days in 50 per cent, and within eleven days in 75 per cent. Trial followed arraignment on information within nine days in 25 per cent of the cases, within twenty-eight days in 50 per cent, and within seventy-five days in 75 per cent of the cases. The duration of the trial was one day in 50 per cent of the cases and two days in 75 per cent of the cases.

Professor Waite also showed that half of those who pleaded guilty were unsentenced fifty-six days after arrest.

W. McKay Skillman, "Slow Justice'-An Answer," 27 Mrchigan State 
From the two groups of jail cases and the two groups of bail cases examined by this writer, and from courtroom observation, it appears that the following factors are related to the duration of cases at recorder's court:

I. Lack of continuous judicial policy with respect to docket, resulting from monthly rotation of the office of presiding judge;

2. The necessity of awaiting the reports of the sanity commission in all murder cases, whether the defendant is tried or pleads guilty;

3. The unpredictability of available judicial man power for felony trials resulting from frequent and prolonged assignment of recorder's court judges to grand jury duty. This problem should cease to exist with the discontinuance of the judicial grand jury system as it existed during observation;

4. The necessity, imposed by statute, of investigation and report by the probation department in all cases where

Bar Journal, August, 1948, pp. 33-37. This article questions Professor Waite's assumption that prompt punishment is the primary function of criminal judicial administration, and asserts the importance of prognosis as to possible rehabilitation in each case. The total case load of recorder's court is approximately 26,000 including misdemeanor as well as felony cases. The misdemeanor cases, Judge Skillman states, are disposed of daily, and the backlog of untried felony cases at the time the article was written was 900 cases (approximately two months' work) out of an approximate annual total of 4,500 . The average jail case, he states, is tried within thirty days of arrest and the average bail case within 120 days of arrest.

Calling attention to the failure of the Waite article to offer comparative statistics, Judge Skillman quotes a letter from the clerk of the court of general sessions in New York, which has an annual felony case load of about 3,500 , and which estimates the average interval from arrest to final disposition as one to six months with an average of about two months in jail cases, and two to nine months with an average of three to four months in bail cases. In homicide cases, the clerk of the New York court says, the interval varies between one month and one year with an average of about five months.

The judge disclaims responsibility for the interval between examination and filing of information, during which time the file is in the prosecutor's office, explains the necessity for balancing each day's docket as to type of case, and points out that a plea of guilty may occur after trial has been scheduled. The necessity of allowing time for the probation department and psychopathic clinic to make investigations and reports are also dealt with. 
the defendant pleads or is found guilty. This interval, like that required by the psychopathic clinic in cases served by that agency, is not long. In no case examined for this study did this interval exceed a month; in most cases it was between seven and ten days. This is interesting, for it tends to indicate that the use of administrative agencies to investigate and diagnose convicted defendants to aid in sentencing does not appreciably slow up the disposition of cases.

\section{Machinery for supervising timely disposition of cases}

The ultimate continuing responsibility for timely disposition falls upon the docket clerk. Once a week, the turnkey of the jail checks the jail list with the docket clerk. All inmates chargeable to recorder's court who have been in custody for what is regarded by either of these persons as an unreasonable length of time are marked, and the case file examined by the docket clerk, who reports to the presiding judge on the status of such cases as appear to the docket clerk to show inadequate reason for delay. In such cases, the presiding judge may require the prosecuting attorney to proceed forthwith. In addition, the turnkey reports each morning to the clerk of the court as to the day's total jail population, which is then checked by the clerk to ascertain its relation to the backlog of pending felony cases at the court. When the jail population shows a rise, a report is made to the presiding judge so that efforts can be made, by docketing more cases each day, by scheduling more trials on Saturday, or by such other means as the presiding judge sees fit, to speed up the disposition of pending felony cases. There is currently a docket committee composed of three judges, who are investigating various suggested methods of dealing with the problem of timely disposition. 


\section{Section 8. Disposition of Case Load}

The size of the case load as well as its character, together with the presence of machinery designed to guard against delay in handling cases, confront the metropolitan court with the problem of safeguarding the quality of disposition by some means of protection from perfunctory routine disposition, from the judicially-uncontrolled administrative discretion of nonlegal personnel, and from a disregard of traditional legal safeguards. This problem has several aspects, among them are the following.

\section{a. Cases Disposed of without Trial}

Cases disposed of by police without court action

A great many cases which in a less crowded area would be subjected to full trial are disposed of by the police in Detroit. The number of such cases cannot be intelligently estimated from the police reports, for the reason that cases reported by the police as "known" to them include only those cases which are regarded as important enough to have been recorded at the precinct of arrest. The classification varies from precinct to precinct and even within the same precinct as the pressures of the work shift.

At all times, however, certain specialized departments of the police dispose of many cases: for instance, the juvenile division, ${ }^{26}$ the women's division, ${ }^{27}$ and the misdemeanor complaint bureau at police headquarters, which handles from twenty to thirty-five cases a day that have been sent in from precincts for prosecution. Here special police personnel, sitting in a room which physically resembles a courtroom, "hear" these cases and dispose of them without the issuance of warrants by advising the parties with respect to their course of conduct. Most of these cases are petty 
neighborhood and domestic quarrels. ${ }^{28}$ The tremendous number of intoxicated persons released after overnight detention without court action ${ }^{29}$ further illustrates police screening which keeps down the case loads of courts operating in Detroit by disposition outside the official orbit of the court.

Cases disposed of by court administrative agencies prior to trial

The pre-court adjustment clinic at recorder's court, the Friend of the Court at circuit court qua reconciliation officer, and the cashier's office at traffic court (which receives fines by mail or at the office and closes cases upon such receipt) dispose of an appreciable number of cases. ${ }^{30}$ So do the probation officers at the juvenile court as to cases which they are able to dispose of prior to the official filing of a petition in the court.

\section{b. Cases Disposed of Summarily}

The number of cases disposed of without trial, in relation to the cases disposed of, is decreasing in the state of Michigan. In 1947 , the decrease was 27.4 per cent in circuit courts outside Wayne County and in Wayne County it was 33.6 per cent. But although in the circuits outside Wayne County, I 4.4 per cent of the cases disposed of were actually tried, in Wayne County only 6.4 per cent of the cases disposed of were tried-an indication that fewer metropolitan cases reach trial. ${ }^{30}$

It is further noted that 22 per cent of the felony cases disposed of at recorder's court in 1947 were disposed of

28 See Detroit Times, August 8, 1948.

29 See supra p. 24.

30 Eighteenth Annual Report of the Judicial Council of Michigan: JUdICIAL StatisTics FOR THE YeAR 1947 (September, 1948), p. 7. 


\section{METROPOLITAN COURTS: DETROIT AREA}

without trial, ${ }^{31}$ and that 95.6 per cent ${ }^{32}$ of the cases disposed of at the court of common pleas were uncontested and hence not subjected to adversary proceedings prior to judgment.

c. Cases Reported as Tried in which Legal Safeguards Are Not Fully Used

In 1947 , over half of the cases which went to final disposition in the felony division of the recorder's court were those of defendants who had waived examination. Of these defendants 4 I.I per cent pled guilty. ${ }^{33}$ As a practical matter, in any of the cases in which the same person who waived examination later pleaded guilty, no one in the prosecutor's office or elsewhere was ever required critically to analyze the case against the defendant. In such cases as involved defendants not represented by counsel, everyone including the defendants may have taken for granted the guilt of the defendants. The large number of cases tried by courts operating in Detroit in which parties are not represented by counsel, and the number of trials in which juries are not used, is related to the disuse of legal safeguards in metropolitan trials. The current practices of trial in the mental division of the probate court, whereby neither doctors nor defendants attend the court proceedings, may also be mentioned in this connection. ${ }^{34}$

It is no doubt partly in order to safeguard quality of case disposition, despite decrease in full adversary trials with counsel and jury, that judges of courts operating in Detroit have extended their use of the investigative and supervisory services of administrative agencies employed

31 Annual Report of the Clerk of Recorder's Court (r947) furnished figures on the basis of which the figure given was calculated.

32 Annual Report of the Presiding Judge of the Court of Common Pleas (1948).

33 Calculated from material contained in the ANNUAL RePort of THE Clerk of the Recorder's Court (1947).

34 See supra pp. 186-193. 
by the courts themselves. In this connection, for example, the use of probation services for over 30 per cent of the defendants in misdemeanor cases disposed of at recorder's court in 1947 is striking, for the use of such services in misdemeanor cases is not mandatory. ${ }^{35} \mathrm{~A}$ similar development is that of the Friend of the Court at the circuit court, which has taken over investigatory and enforcement duties which were once thought of, and are still thought of in many areas, as the prerogative of the attorneys representing the divorcing parties. ${ }^{36}$

\section{d. Age and Duration of Cases ${ }^{37}$}

Data assembled by this and other writers demonstrate that obtaining timely disposition of cases is a major problem to the Circuit Court of Wayne County and to the felony division of the recorder's court. The unavailability of data concerning the probate and juvenile courts prevent comparison of the age of cases problem there; however, observation indicates that in the mental division of the probate court, quality of disposition has been sacrificed to speed. It is most notable that traffic court and common pleas court, which dispose of the overwhelming majority of their cases by proceedings short of full adversary trials, experience little if any delay in bringing a case through the docket to final disposition. The two courts in which elaborate machinery has been developed to handle dockets, and in which most attention must be paid to delay, are the courts of superior jurisdiction in which many full trials take place and which have the largest number of social and criminal problems such as necessitate special effort to guard against perfunctory, arbitrary, or otherwise poor disposition.

\footnotetext{
${ }^{35}$ See supra p. 165.

${ }^{36}$ See supra pp. 173-180.

37 Supra pp. 205-213.
} 
It is apprehended that the problem of timely disposition of cases is the opposite aspect of the problem of protection against "steam-roller" disposition discussed hereinabove. The entire problem is that of obtaining reasonably prompt disposition while protecting quality of disposition, and that problem is inevitably encountered in the operation of any court with a large case load each unit of which passes through the various hands of many court employees on its way to disposition. This problem is almost certainly different in character and extent in any metropolitan area than elsewhere, and is perhaps chief among the problems which can be unhesitatingly pointed out as characteristic of metropolitan courts.

Treatment of the duration and quality problems should be handled as part of a single larger problem each aspect of which is to be determined in relation to the other. 


\section{Operative Relationships Among Various Courts and Law Enforcement and Welfare Agencies in the City of Detroit}

Section i. Overlapping, Defective, and Conflicting Jurisdiction over Subject Matter and Person

a. Small Claims

T $\mathrm{N}$ MOST civil actions where the matter in controversy is between $\$ 100$ and $\$ 1,500$, action may be brought in the court of common pleas or in the Circuit Court of Wayne County, with the exception that, until a statutory amendment which postdated the assembling of this material, all actions against a municipality were specifically excluded from those over which the court of common pleas has jurisdiction. ${ }^{1}$ To ascertain the number of cases brought in the circuit court which might have been brought in the common pleas court, all the law judgments entered by the circuit court in the year ending November 30, 1947, were examined. Although jurisdiction is based on the amount prayed for, these figures were based on the amounts recovered, since in a large group of cases the judgments are thought more accurately to reflect the actual value of the claims than the amounts asked, which are often, if not usually, higher than the sum regarded even by the plaintiff's attorney as the real value thereof. ${ }^{2}$

1 666.4 Comp. Laws (1948); 27.3182 Mich. Stats. Ann.; 728.1 Comp. Laws (1948); 27.365 M Mrch. Stats. AnN.

In r 949 , by P.A. no. $x_{49}$ (I949), the legislature altered the statute to permit the court of common pleas to entertain actions against certain municipal corporations. This was in response to the recommendation made by Judge Ira W. Jayne, of the Circuit Court of Wayne County. See infra p. 220.

2 See Fourten anth Annal Report of the Judicial Council of the State 
Of the I,23I judgments entered during the year, 50.3 per cent were for amounts less than $\$$ I, OoO and 75.I per cent for amounts less than $\$ 1,500$-that is, more than three fourths of the work done by the circuit court on the law side was done within the area concurrent with common pleas. A further analysis of the same list of judgments showed the same predominance of small claims in both jury and nonjury cases: of 347 jury trials, 8 I. I per cent resulted in judgments for $\$ 1,500$ or less and 56.7 per cent in judgments of $\$ \mathrm{I}, 000$ or less. Of 994 nonjury trials, 56.6 per cent were for $\$ I, 000$ or less; 7 I.I per cent for $\$ I, 500$ or less.

In a recent article, ${ }^{3}$ the presiding judge of the Circuit Court of Wayne County analyzes this group of cases in detail, and concludes that the widespread bringing of small claims in the circuit court "has contributed heavily to jamming its dockets." He has recommended that the legislature empower the common pleas court to try the large number of cases against the city of Detroit, and that legislation similar to that of New York be enacted so as to discourage the bringing of small claims actions in the circuit court by preventing the plaintiff from recovering costs in any case in which the judgment is below the maximum jurisdiction of the lower court.

Of r 96 judgments for plaintiff rendered on July 20, 1948 , a date taken at random, in the court of common pleas, 158 were default judgments. In amounts, two of the 196 were between $\$ 1,00 I$ and $\$ 1,500$ and three between $\$ 50 I$ and $\$ \mathrm{I}, 5 \mathrm{OO}$; all five were default judgments. Forty-two were between $\$ I O I$ and $\$ 500$. Thus 23.4 per cent of this group

OF NEW YORK (1948), at p. 64, reporting the results of a similar study using the same technique.

"Ira W. Jayne, "The Mouse in the Mountain," I6 The Detroit Lawyer, December, 1948, 237-239. The 1949 amendment cited at supra n. $\mathrm{x}$, was a result. 
were for amounts within the area of concurrence with the circuit court.

Of 100 contested cases ready for trial on July 2 I, I948, in common pleas, ten plaintiffs asked between $\$ I, O O I$ and $\$ \mathrm{I}, 500$; seventeen for amounts between $\$ 5$ OI and $\$ \mathrm{I}, 000$; fifty-nine for amounts between $\$ 100$ and $\$ 500$, so that of this group, 86 per cent were within the bracket of concurrence. As to type of case, fifty were actions in trespass, one trespass on the case, one conversion, and forty-eight assumpsit. From this it is clear that liquidated and unliquidated claims are fairly evenly represented.

Here, then, is an important area of overlapping jurisdiction and one which affects a large portion of the case load. It is very interesting that despite the relative speed with which cases are disposed of in the common pleas court, so many cases are filed in the circuit court. Many liquidated claims are filed in the court of common pleas, more than 90 per cent of the case load of which is defaulted. However, a random exploration of the calendar record of some of the circuit court judgments indicated that some of the small claims cases filed in the higher court also represent actions on notes, past-due accounts, and other liquidated claims. Other factors in the choice include the desire of certain attorneys to earn a bigger fee by putting on an elaborate trial, consciously exaggerated amounts alleged for bargaining purposes, and the desire to seek that alternative which is regarded as having more prestige, or in which the attorney reposes a higher confidence. These factors all together seem to outweigh the fact that a case filed for trial in the court of common pleas may reach trial within three weeks after it is at issue, as compared to the far more lengthy period in the circuit court. ${ }^{4}$ 


\section{METROPOLITAN COURTS: DETROIT AREA}

\section{b. Landlord-Tenant Cases}

There are a great many rent disputes in Detroit, where the housing shortage is acute. Although the common pleas court can determine and collect amounts due for rent, such possessory actions as eviction are the exclusive prerogative of the circuit court, exercised by its circuit court commissioners. Since nonpayment of rent is a frequent cause for seeking eviction, the fact that control over the amount due and the eviction are in different tribunals results in much duplication of court effort. The extent of the problem may be indicated by the fact that in 1947 , I 7,300 eviction cases were started in the office of the circuit court commissioners in Wayne County.

\section{c. Trials de novo on Appeals}

Cases appealed from lower courts to the Circuit Court of Wayne County are tried de novo.5 Of the I,23 I law judgments for plaintiff entered in the Circuit Court of Wayne County in the year ending November 30, I947, eighty-four represented dispositions of appealed cases, and of this number, only $\mathrm{I} 3$ per cent were reversed. Of the eighty-four, five judgments were for less than $\$ 50$, three were between $\$ 50$ and $\$ 100$, seventy-eight were under $\$ \mathrm{I}, 000$, and six were between $\$ \mathrm{I}, 000$ and $\$ \mathrm{I}, 500$. The practice of conducting two trials of such small claims actions seems extravagant.

5678.7 Comp. Laws (1948); 27.3497 Mrch. Stats, AnN. In Wayne County, under Michigan court rule no. 2 , no. 76 .

After the period of the survey, this was changed by Public Act No. 149 (I949), which provides that appeal or certiorari shall lie from a decision of the court of common pleas, "but not for trial de novo, where the case shall be reviewed in the same manner... as cases appealed from the circuit court are now reviewed in the supreme court. . .." 


\section{d. Mental Cases}

The probate court, which has jurisdiction over the commitment and release of the mentally afflicted, handled all petitions alleging that children are mentally afflicted and praying for their commitment to institutions for the insanealthough it would seem that the juvenile court, with its plenary jurisdiction over children and with its special facilities for diagnosing the mental condition of children, would be better able to dispose of these cases. The circuit and recorder's courts, in the exercise of criminal jurisdiction, may have a sanity commission inquire into the mental condition of a defendant, and commit him, if found insane, to a state institution. Criminal sexual psychopaths, diagnosed by court-appointed psychiatrists, may also be committed by courts exercising criminal jurisdiction over those accused of criminal offenses. This authority is frequently used by the recorder's court and by the Circuit Court of Wayne County.

\section{e. Chronic Alcoholics}

Unlike the mentally afflicted criminals described in the previous paragraph, the alcoholic criminal defendant whose addiction is of such a nature as to constitute a mental affliction may not be committed for institutional treatment by the court exercising criminal jurisdiction, but only by the mental division of the probate court. The requirement that such petitions be signed by the personal guardian of the alleged chronic alcoholic, instead of by someone with knowledge of the facts, precludes the hospitalization of chronic alcoholics who appear before other courts on the petition of probation officers, psychologists, or psychiatrists who have knowledge of their condition. Such persons may not 
be appointed personal guardians, and hence cannot sign petitions for commitment. ${ }^{6}$

The resulting inability of courts other than the probate court either to provide for the treatment of chronic alcoholics or to refer such cases to the probate court is of tremendous effect upon the probation case loads of the recorder's, circuit and juvenile courts, and upon the misdemeanor division case load of the recorder's court. Many domestic problems are affected by the uncontrolled drinking of some member of the family. This may result in a criminal nonsupport case, a divorce case, or a case arising out of failure to provide support as ordered by a divorcing court. Such drinking may be the reason for the abandonment, neglect, or delinquency of a child before the juvenile court. Children themselves may come before the court as alcoholics-nineteen boys were found guilty of delinquency consisting of drunkenness by the juvenile court in 1947 , and uncontrolled drinking was involved in the delinquency of many other delinquent children handled by the court. ${ }^{7}$ The traffic court often encounters alcoholism: for instance, there were $\mathrm{I}, 003$ cases of drunk driving there in 1947 , and many other cases in which this condition was an operative force in the offense disposed of. ${ }^{8}$

${ }^{6} 703.1$ (6) Comp. Laws (r948); 27.3178 (20r) Mich. Stats. Ann.

On June 23, I950, the register of the probate court comments: "Act III of the Public Acts of 1945 amended Section 330.18 of the Compiled Laws of I 945 by authorizing the petitions for commitment of chronic alcoholics to be made by the guardian, next-of-kin or some other suitable person designated by the Probate Judge. This, of course, enlarges the persons who can petition from that stated by you in the text."

The I 94.5 amendment did not serve the purpose of having petitions signed by recorder's court officers with knowledge of the facts. Whether this is because of the wording of the statute, or the lack of rapport between probate judges and recorder's court personnel, those interviewed on the point do not agree.

${ }^{7}$ Information supplied by the Detroit Police Department.

${ }^{8}$ Information supplied by chief deputy clerk, traffic court. 
A majority of the persons arrested as intoxicated in Detroit never reached court. How many of those weeded out-on the basis of their docility-are in critical physical and mental condition is not known. There are over 1,400 men in Detroit, however, who are known to recorder's court as hopeless alcoholics, who have been in court on charges of drunkenness from five to 150 times. There are over twenty-five court dispositions a day at recorder's court on charges of drunkenness. ${ }^{\circ}$ Over 30 per cent of those disposed of by the misdemeanor division in October, I948, were found guilty of drunkenness. In $1947,8,783$ persons were found guilty of drunkenness by the recorder's court. ${ }^{10}$ Yet, although the recorder's court is the tribunal which encounters the weight of the case load of chronic alcoholics, its authority to deal with them is limited to sentencing each convicted defendant to a maximum of ninety days' imprisonment in the Detroit House of Correction.

Courts other than the probate court do what they can to control the chronic alcoholics who come within their jurisdictional orbits by making sobriety a condition of probation, by diagnosis and recommendation of voluntary application for medical treatment, and by such co-operation with local social and medical facilities as probation officers or clinic employees are able to arrange. The probate court, in 1947 , committed fifty persons ${ }^{11}$ as alcoholic, and dismissed nineteen chronic alcoholic petitions.

\section{f. Criminal Cases}

The gradual growth of the recorder's court into a tribunal with jurisdiction over all felonies and misdemeanors

${ }^{9}$ Information supplied by probation department, recorder's court.

10 Information supplied by clerk of the recorder's court for the year; for the month of October, information was computed directly from the court sheets.

11 Information supplied by the head of the mental division, probate court. 
committed within the city of Detroit has been described. ${ }^{12}$ This growth has left the circuit court with a small criminal case load consisting of felonies committed within Wayne County outside the city limits. Five hundred such cases were disposed of in 1947. By a similar historical accident, the court of common pleas, designed as a civil tribunal for small claims, conducts preliminary examinations of those accused of felonies committed outside the city limits but inside the county. Fifty such examinations were conducted in 1947. Relief from their small criminal case loads would free both the circuit and common pleas courts to concentrate on their large civil case loads. If, however, the circuit court were also relieved of its small claims case load, as has been suggested, ${ }^{13}$ it would be left with only a few controversies involving large amounts of money on the law side of the court, and would spend most of its time in chancery cases, most of which are divorce and similar domestic relations cases.

\section{g. Cases Involving Minors}

Machinery for waiver of jurisdiction to cure overlap

The juvenile court has exclusive jurisdiction over children under seventeen. ${ }^{14}$ Where a child under seventeen but over fifteen is accused of a felony, the juvenile judge may waive jurisdiction upon motion of the prosecuting attorney and after investigation and notice to parents. ${ }^{15}$ This provision is currently construed by recorder's court as jurisdictional, so that a waiver signed by the juvenile judge must precede the issuance of a warrant on any complaint against a child

12 See supra pp. 44 et seq. Number of criminal cases disposed of by circuit court supplied by circuit court, criminal examinations taking place at common pleas court supplied by common pleas court.

13 Jayne, loc. cit.

14 See supra pp. $37^{-40}$.

is Ibid. 
between fifteen and seventeen. In Detroit, such waivers follow investigation by a juvenile court probation officer and full examination and hearing in juvenile court, and contain as part of the order waiving jurisdiction a finding that it is to the best interests of society and the defendant that the trial take place in the court of criminal jurisdiction. In I 945, the Juvenile Court of Wayne County waived a total of sixty-seven of its $\mathrm{r}, 990$ official delinquency cases. In 1947 , so far as information was obtainable, only one such waiver took place. ${ }^{16}$

Where the chancery court has obtained jurisdiction of children under nineteen in proceedings concerning the divorce of the parents or the custody of children following the divorce, the juvenile court obtains exclusive jurisdiction over such children where the chancery court waives its own jurisdiction. During 1948, there were only seventy-seven waivers of jurisdiction by the Circuit Court of Wayne County to the Juvenile Court of Wayne County, although during that year 4,539 new cases involving minor children were taken up for supervision by the Friend of the Court as a department of the Circuit Court of Wayne County. ${ }^{17}$

\section{Wayward minors}

Juvenile court jurisdiction of children over seventeen is limited to wards of the court over whom jurisdiction has previously been acquired, and to children between seventeen and nineteen of the group formerly known as "wayward minors"-late adolescents beyond parental control and in

16 Juvenile Court of Wayne County reported that it had no information recorded on this point for 1947 . The 1945 figure is from the First ANNUAL Report of the Michigan Juvenile Court RePorting System, issued by the State Department of Social Welfare for Juvenile Institutions Commission, at p. 33 .

The r 947 information given was supplied by the statistical department of the Detroit Police Department.

17 Information supplied by the Friend of the Court, Circuit Court of Wayne County. 
danger of drifting into criminal behavior, who should be helped and rehabilitated by the specially trained workers at juvenile court and protected from contamination by the hardened criminals with whom they would associate if tried and sentenced under the court of general criminal jurisdiction. The juvenile court is given concurrent jurisdiction with the court of general criminal jurisdiction over children falling within this group, although the present statute no longer defines them as "wayward minors." 18

According to juvenile court and recorder's court officials, the original "wayward minor" act was passed in order to correct a situation which is prevalent only in metropolitan Wayne County. There large numbers of late adolescent marauders, operating in gangs, constitute a threat to the public peace by stealing automobiles, molesting and attacking passersby, terrorizing small restaurants and drug stores in sparsely policed neighborhoods, and by committing other vandalisms. Unlike other children within the juvenile court jurisdiction, these wayward minors may be detained in the county jail for thirty days, and after commitment to the Michigan Corrections Commission pass within the authority of that commission rather than that of the juvenile court. It is provided, however, that such children are to be confined separate and apart from persons committed by courts of criminal jurisdiction.

The present machinery, then, providing for concurrent jurisdiction, leaves the prosecutor and police with the choice of tribunals: a wayward minor may be charged as such in juvenile court, or may be charged in recorder's court under the specific offense which makes him a wayward minor. In operation, the current statute is unsatisfactory to all, not only because the juvenile court is given responsibility for a

18 See supra pp. 37 et seq., and the discussion in that section of the elimination of "branding" by eliminating from the present statute the definitions of different types of children who come within the jurisdiction of the juvenile. court. 
group of children over whom it loses control after commitment, but because many persons in this age group are already confirmed criminals who have committed several serious offenses. During observation, habeas corpus proceedings were brought on behalf of twelve girls described on the circuit court docket as twelve "Mary Roes." The writs were granted when it was found that these girls, having been committed by the juvenile court to the corrections commission under the wayward minor provision of the present Juvenile Court Act, had been confined by the commissioners in the Detroit House of Correction, an institution to which persons committed by courts of criminal jurisdiction are committed. During the investigation which followed the publicity with which the cases were attended, it was found that the house of correction contained a total of thirty-four girls who had been committed as wayward minors through the juvenile court. That is, children routed through juvenile court because they seemed likely to be worth protecting from contact with adult criminals were, after trial, illegally confined with such criminals.

After the release of the first twelve, the present writer checked their records with the circuit and recorder's courts, but was unable to obtain information from the juvenile court owing to the policy of "protected record" which prevents the disclosure of information there. At least four of the girls were shortly apprehended and brought before the recorder's court for fresh violations of the law: these four were found, in August 1948, to be on probation to the women's division of recorder's court. One girl had been arrested for shoplifting in a Detroit store within thirty minutes of her release on the habeas corpus writ. These findings tend to indicate that some of the wayward minors originally routed through juvenile court are already hardened criminals who cannot be rehabilitated by separation from others. 
The city of Detroit has recently passed a curfew ordinance, under which many unruly late adolescents are currently appearing before the ordinance referees of the traffic court. Many others, charged with loitering, are disposed of by the misdemeanor division of recorder's court, where thirty-six youths were convicted of that offense on October 4, I948, a day picked at random.

Aside from the unworkability of a statute which is so drawn as to deprive the juvenile court of control over children whom it is desired to rehabilitate through specially trained supervisory personnel attached to that court, the present difficulty arises from the fact that the police and prosecutors, who make the selection of the tribunal which is to dispose of late adolescent offenders, are channeling many serious offenders into juvenile court, and many misguided but not yet thoroughly contaminated adolescents into the recorder's court. While there is clearly a need for the specialized functions of both tribunals, the choice of tribunal might better be made after investigation, diagnosis, and recommendation by those equipped professionally to deal with the legal and social aspects of each case, as might have been done in Detroit had the legislature not abandoned the recently established Michigan Youth Commission. ${ }^{10}$ In New York, a local youth board, organized under

$1925.243(\mathrm{I})-(4)$ Mrch. STats. AnN. expired by its own terms on July I, 1947. Of it, Professor Lowell Juilliard Carr, of the sociology department of the University of Michigan, says: ". . Michigan created a State Youth Commission. ... With a change of administration, however, the legislature changed its mind about a centralized agency for planning prevention, and abolished the Youth Commission, which had never had an adequate budget in the first place. The result . . . was . . . a state spending upwards of half a million dollars annually on delinquency prevention services of one kind or another without any guiding, over-all philosophy of delinquency prevention, and without any central agency capable of drafting one or applying it if one existed. All this, of course, in striking contrast to the situation in California, Minnesota, Wisconsin, and Massachusetts, and especially in contrast to the situation in New York." "Organization for Delinquency Control," 26r Annals of the American Academy of Political and Social SCIENCE, r949, at p. 66. 
the state commission, is said to review each youthful offender arrested in the city, and after expert investigation and recommendation to select the tribunal most appropriate for each. Under the present Michigan statutes, there is no means whereby such selection of a tribunal can be made.

\section{Domestic cases}

Cruelty to children, abandonment of children, and contributing to delinquency of minors are all criminal offenses cognizable by the court of general criminal jurisdiction, and in all of these cases a separate procedure in juvenile court for the child may be used. Furthermore, any or all of these offenses may be encountered by assistant Friends of the Court in supervising children of divorced persons, and may be handled by the Friend through exertion of the control of the circuit court over care and support of such children.

Many observed cases displayed domestic discord which had first reached court action as criminal nonsupport cases in the recorder's court, which had resulted-sometimes after several years and after repeated nonsupport convictionsin divorce action in the circuit court, and in anywhere from one to a dozen contacts with the juvenile court for delinquency, abandonment, or dependency of the children of the same families.

Paternity out of wedlock cases can be handled in any one of the following ways, in the city of Detroit:

I. The parents may be united under the Secret Marriage $A c t^{20}$ in either the probate or juvenile court, depending on the age of the parents;

2. A certificate of acknowledgment of parenthood, which constitutes a basis for legal liability for the support of the child, may be filed in the probate court by both parents,

20 551.20I Comp. Laws (x948); 25.5 I Mich. Stats. AnN. 
or-if the probate court deems it necessary to protect the privacy of the mother-by the father only $;^{21}$

3. Civil proceedings in chancery may be had in circuit court, wherein the father acknowledges paternity and submits to an order whereby the circuit court determines the amount of support which the child is to receive $;^{22}$

4. Bastardy proceedings in the misdemeanor division of recorder's court originate as criminal proceedings with the mother acting as complainant. After examination, and finding by the justice that there is sufficient evidence to establish the prima facie guilt of the alleged father, the case is bound over - not to the felony division of the recorder's court, but to the circuit court-for further proceedings in the nature of chancery inquiry leading up to the determination of the amount of support which the father is required to contribute to the child's support and to the medical and lying-in expenses of the mother $;^{23}$

5. Where the father is unknown, out of reach, unemployable, or where no suitable home for the child can be supplied by the mother, the child may be placed for adoption. Adoption proceedings involve both probate and juvenile courts. ${ }^{24}$

The duplication of jurisdiction as to these domestic cases is very significant, because the number of such cases is relatively large in a metropolitan area, ${ }^{25}$ and for the further reason that such cases as these domestic cases are most often disposed of by placing the offender on probation and extending family supervision over a long period of time.

21 702.83 CoMp. Laws (1948); 27.3 78 (153) Mich. Stats. ANN.

22722.612 CoMp. Laws $(1948) ; 25.462$ Mich. Stats. AnN.

23722.601 Comp. LaWs (1948); 25.45 I Mich. Stats. Ann. et seq.

24 See p. 42.

25 See supra pp. 25-30. 
Thus, in many cases, probation workers from several different courts are trying to rehabilitate the same family.

\section{Section 2. Extent of Co-operation among Courts}

The six courts in Detroit exist independently of one another. There is no organizational integration; instead, the impetus toward specialization has resulted in transforming what used to be four courts into what are now six. In two instances-the juvenile division at probate court and the traffic division at recorder's court-the specialized division has become structurally and operationally distinct from the parent. Two others-recorder's court's misdemeanor division, and the court of common pleas-represent widely divergent results of an early cleavage between the civil and criminal duties of Detroit justices. ${ }^{26}$

This tendency to specialization and to the growth of special tribunals, coupled with the lack of adequate machinery for integration from court to court within the metropolis, makes co-operation difficult.

26 When Detroit was incorporated in 1806 , each ward was made equivalent to a township. An 1832 local act gave Detroit constables the same powers over minor civil and criminal cases that township justices had. There were, at that time, four justices, or constables, in each ward. SwEETMAN G. SMITH, Practice and Procedure of the Common Pleas Court of the City of Detrort (Chicago: Callaghan and Company, 1938), especially pp. iii-iv, and $\S \S \mathbf{I}, 2$.

In 1850 , one Detroit justice was designated to act as police justice, and took over all duties of all city justices relating to minor criminal offenses within the city of Detroit. O'HAGAN, op. cit., p. 2, L. 1850, act 3or. In 1855 , a police court for the city of Detroit took over the jurisdiction of the police justice. O'HAGAN, ibid., L. 1885 , act $\mathbf{1} 6 \mathbf{x}$.

This police court became the misdemeanor division of the recorder's court when, in 1857 , that tribunal was created and given jurisdiction over all criminal offenses committed within the city limits of Detroit. O'HAGAN, ibid., charter (1857), chap. VI, $\$ \S 5$, 50.

The justices who had been left with exclusively civil jurisdiction when in 1850 the police justice was given specialized criminal work, were later consolidated into the present common pleas court. See supra pp. $44-45,48$. 
a. Exchange of Personnel, Facilities, Records, and Information

\section{Exchange of judicial personnel}

Statutes provide that a circuit court judge may act for either branch of the recorder's court, ${ }^{27}$ for an absent or disabled probate judge, ${ }^{28}$ or in place of the judge in a juvenile case. ${ }^{29}$ Another statute provides for assignment of a recorder's court judge to traffic court, and the machinery providing for state-wide exchange of circuit judges supports the assignment of recorder's court judges to circuit court. ${ }^{30}$ In Wayne County, the same result may be obtained by assigning civil transitory actions in Detroit, under circuit court control, to individual recorder's court judges. ${ }^{31}$

In practice, the machinery by which judges may be exchanged is very little used in Detroit. Circuit judges from outside Detroit visit the traffic court about once or twice a month, according to the presiding judge of the traffic and ordinance division. No judges visit the recorder's court, and judges from Circuit Court of Wayne County do not visit the traffic court. In I94I, I42 civil cases were referred by circuit court to recorder's court. We are informed by both courts that the practice was discontinued in 1943 , and it is interesting to note that the practice of assigning re-

${ }^{27} 691.202$ COMP. LAws (1948); 27.292 Mrch. STATs. ANN. giving the presiding judge authority to designate one or more judges to hold court in the circuit and recorder's courts on requests of the governor, was upheld in People v. Buckley, 302 Mich. I2 (I942). In People v. Mellor, 302 Mich. 537 ( 1942 ), it was held that a visiting judge may properly determine an ordinance case.

28 7or.i ( Comp. Laws (1948); 27.3178 (rr) Mich. Stats. Ann.

${ }^{29}$ Loc, cit.

30725.18 Comp. Laws (r948); 27.3958 Mrch. Stats. AnN. Upheld in People v. Buckley, 302 Mich. 12. (1942).602.53 Comp. Laws (1948); 27.190 Mich. STATS. AnN.

${ }^{31} 725.23$ CoMp. Laws (1948). This statute, Act 24 of 1933 , is not included in Mich. STATs. AnN. because it is applicable only to the recorder's court, a municipal court. 
corder's court judges to the Circuit Court of Wayne County was discontinued in the same year. ${ }^{32}$

In practice, there is no interchange of personnel between circuit and probate courts in Wayne County. Since the probate court and the juvenile division are operated as separate courts, it may be noted here that one of the five probate judges was spending a day and a half a week at the juvenile court, at the request of the juvenile judge, during the field-work period of observation.

\section{Exchange of other personnel}

The jury panel at recorder's court serves the traffic court. The probation department and psychopathic clinic at recorder's court are shared by the traffic court, and the clerk of recorder's court is ex officio clerk of traffic court, which in practice means that he acts as liaison officer between the two courts.

Aside from the foregoing, there is no machinery for the exchange of nonjudicial personnel.

\section{Exchange of facilities}

The psychopathic clinic at recorder's court accepts references from other courts and from public and private social agencies when its work permits. During I947, .48 per cent of its total load of 1,924 cases were referred by sources outside the court. These sources were chiefly social agencies

32 Eighteentit Annual Report of the Judicial Council of Michigan, $o p$. cit., table VII, shows 436 court days spent in 1933 by Recorder's Court judges assigned to the Circuit Court of Wayne County; 298 days in 1938, 154.5 in 1942,57 in 1943 , $O$ in 1944 , and thereafter.

On June 1,1950 , after the book had been put into galley proof, the presiding judge of the recorder's court requested the governor to have the state presiding circuit judge assign a visiting circuit judge to the court for two months. 
and institutions in the area; references from other courts occur very seldom. ${ }^{33}$

The child study clinic at the juvenile court receives references from public and private social agencies, and is willing to accept references from other courts. During 1947 , although one fourth of its load had been referred from outside the juvenile court, no cases had been referred by other courts. ${ }^{34}$ The juvenile court investigates adoptions for the probate court, and the detention home at the juvenile court acts as a shelter for children detained by other courts. For instance, during 1947 , twenty-seven children were held as police witnesses at the detention home. ${ }^{35}$

The probation officer at the Circuit Court of Wayne County supervises probationers from Wayne County justice and municipal courts; in 1948,538 such probationers were supervised. ${ }^{36}$

The foregoing comprise all the instances of exchange of facilities in Detroit of which the writer was able to learn. Attention is called to the fact that all of them represent the extension of diagnostic and supervisory services by heads of specialized administrative agencies within courts as a matter of departmental courtesy to persons and agencies outside the court, rather than as a matter of judiciallydetermined court policy or as a matter of right.

\section{Exchange of records and information}

There is no provision for the exchange of records or information from court to court within Detroit. The obtaining of such information depends on the relationships of individual members of the various court organizations. The policy of most of the court personnel appears to be that

33 Information supplied by clinic.

34 Information supplied by clinic.

${ }^{35}$ Information supplied by police.

${ }^{36}$ See supra pp. $152-\mathrm{r}_{5} 6$. 
records are confidential, and the practice is that such cooperation is rarely sought and even more rarely given.

There is occasional co-operation of an unofficial and voluntary kind between individual employees who aid one another in spite of the lack of official channels for exchange of information. Also, court employees are sometimes able to obtain information or co-operation from another court indirectly, by appealing to the police or to a public or private social agency.

For instance, the women's probation department at recorder's court, when it learns of cruelty, neglect, or abandonment of a child by one of its probationers, makes it a policy not to notify the juvenile court, but to notify the women's police division, which in turn takes steps resulting in juvenile court action. In the same manner, the juvenile court, when one of its employees learns of behavior which constitutes violation of a circuit court order to support and care for children of divorced persons, notifies the women's police division instead of the Friend of the Court. The 1948 report of the Friend of the Court shows no cases referred by other courts, but shows I 7 cases referred by the women's division of the police department, which is used by all probation departments as an unofficial clearing house for domestic relations cases which involve more than one Detroit court. In this connection, it is notable that when any law enforcement or court agency learns of a seduction or rape which has resulted in pregnancy, the case is referred to the public welfare department, which chooses one of the five court procedures which may be instituted. ${ }^{37}$

These techniques, however, from the point of view of judicial administration, have serious disadvantages: they occur mostly outside the orbit of direct judicial control and hence imperil the control by judges of the operation of their 
courts; they take place among individuals within a highly departmentalized court personnel, hence are not likely to harmonize with court policy determined in the light of judicial grasp of the problem in its entirety; and at best they consist, in sum, of mere amelioration of the disconnectedness of the various courts, rather than comprising an affirmative solution to the need for vigorous and intelligent co-operation.

\section{Transfer and exchange of cases}

Bastardy cases originating in the recorder's court are bound over to the circuit court after examination. ${ }^{38}$ Adoption cases, after investigation at juvenile court, are sent to probate court for completion..$^{39}$ One of the psychologists at the psychopathic clinic at recorder's court has been deputized as a deputy sheriff, to act as petitioner in cases coming through the clinic where the defendant needs commitment by probate court as insane. When such a case occurs, the judge and probation department at recorder's court are asked to continue the criminal proceedings until the defendant can be committed. This procedure is used in from one to two dozen cases a year, and is an example of cooperation worked out between individual members of the staff at the mental division of probate court and the psychopathic clinic at recorder's court.

The writer has been unable to find other examples of exchange or transfer of case load.

\section{b. Areas of Inadequate Co-operation between Courts}

"Protected record" at juvenile court

The present statute provides that a juvenile court disposition shall not be evidence against the child in proceedings 
in another court, and that the records of the juvenile court shall be open only by court order to persons having a legitimate interest therein. ${ }^{40}$ The crippling effect of this restriction upon other courts is illustrated by People v. Smallwood, , $^{41}$ where recorder's court, in trying a father for the statutory rape of his daughter, excluded evidence (on crossexamination) of the girl's previous record of sex offenses. The Supreme Court of Michigan held that exclusion of testimony as to the juvenile court record, despite the protective statute, was a denial of the defendant's constitutional rights, since the question was vital to establishing the falsity of the charges. Dean Wigmore regards such statutes, when applied to known sex offenders, as "a suppression of means of truth," and as "indefensible on any grounds."

Delinquent children usually have relationships with adults who are guilty of criminal offenses arising out of the facts constituting the delinquency, while dependent and neglected children almost always are the product of the breakdown of family life through conduct which may be the subject of court action at recorder's or circuit court. At present there is a large area of confusion and misunderstanding as to the handling of such relationships and such families. Though not the only factor, the stringent policy of the juvenile court to protect its record by revealing no information about any juvenile court case to any employee of another court contributes to this confusion. In an observed case, for instance, the juvenile court declined information regarding the status of two children who were objects of a custody and support order of the circuit court. The information was requested by the Friend of the Court, an officer whose inquiry would seem to be prompted by a

40 7r2A.2; 712A.23; 712A.28 COMP. LAws (1948);27.3178 (598.2); 27.3178 (598.23); $27.3178(598.28)$ Mich. Stats. AnN.

41 306 Mich. 49 (1943). John Henry Wigmore, On Evidence, 3 d ed. (Boston: Little, Brown and Company, r940), Vol. I, pp. 675-6. 
legitimate desire to take steps which would protect the children.

It is pointed out by the juvenile court that much of the present duplication and confusion arises because the police and prosecutors make the decision whether a given case should be handled by juvenile court action as to the children, or by criminal proceedings in recorder's or circuit court against the adults, or both. They believe that the juvenile court, in order to discharge its obligation to protect children under its care, must scrupulously protect their privacy, and that all cases involving children should be referred directly to the juvenile court, which could act as a clearing house for all social and legal problems arising out of each case and could recommend to other courts such action with regard to adults as was desirable in each case.

The "protected record" policy, however, is frequently circumvented, in Detroit. Police case histories, for instance, always include the date, nature, and action taken by the juvenile court for each person, and probation officers from other courts routinely obtain this information in investigating each new case. On April 18, 1948, for instance, in a random check of 500 new felony cases which had reached the recorder's court probation department, I 27 records showed previous juvenile court delinquency contacts. Interviews with families, neighbors, police officers and case workers also often disclose to an inquiring probation officer or Friend of the Court the nature of the juvenile court action with respect to certain children. The present policy, therefore, though soundly rooted in a desire to protect children from humiliation and from acquiring a bad reputation through juvenile court contacts, often seems to hamper other courts without actually extending protection. 


\section{Family support}

There are several court agencies substantially engaged in enforcing family support: the juvenile court dependentneglect department, the pre-court adjustment division of the recorder's court probation department, the domestic relations division of the recorder's court probation department, the probation department at circuit court, and the Friend of the Court at the circuit court. Although there is considerable overlapping in their case loads, there is little cooperation from court to court on these cases. Each agency is largely composed of overworked, conscientious professional people who regard themselves as in a fiduciary relationship with the people in their case loads-for instance, they call them "clients." Each employee is loyal to his own agency and proud of its work. These attitudes account in no small measure for the success of these agencies in extending supervisory control over families. They do not, however, conduce to ready co-operation with other agencies in other courts, and when coupled with the lack of any official channels for co-operation, result in the present positive policy of nonco-operation.

This policy is frank and open. Each worker, because he thinks his own agency is the only one doing a really good job, because he wants to protect the privacy of his clients, because he has enough work of his own to do without doing somebody else's, and because he does not want to lose his job by creating complications, declines to disclose the contents of his files to workers from other agencies who request such information, unless the worker is a personal friend, or unless the court has specially ordered such disclosure.

One result has been that unscrupulous attorneys have turned this particular area of duplicate activity into a means of preventing any court from enforcing support. In one case, for instance, a defendant convicted in recorder's 
court of assault and battery on his divorced wife was placed on probation to pay $\$ \mathrm{I} 2$ a week. He refused to do so on the ground that the circuit court support order totaled only $\$ 10$, and that the recorder's court was interfering with the jurisdiction of the circuit court to determine and enforce support. When the recorder's court judge sentenced him to jail for violation of probation, the attorney obtained a writ of habeas corpus from the circuit court. Although this writ later was vacated on a technicality, and although a later atempt to obtain a habeas corpus writ was unsuccessful, the use of the authority of one court to block another from achieving a common purpose caused the judges and probation officers of both courts to seek means of better integrated co-operation in support cases.

A resulting investigation disclosed a number of cases in which men placed on probation to recorder's court for nonsupport had filed suit for divorce at circuit court, had notified the recorder's court probation officer of the pendency of the divorce action (which caused the probation department to close its file), and had then left the state before the circuit court had time to enter a temporary support order. In one such case, the man was located in Georgia, but that state refused to extradite for the reason that the governor of Georgia did not recognize failure to support as a crime for which extradition papers should be honored. Instances of attempts to evade both recorder's court and circuit court jurisdiction by slipping out of the state increased after this case.

At present, all male divorce plaintiffs are subjects of an immediate investigation by the Friend of the Court, with particular attention to their status at recorder's court. Further, recorder's court probation officers are now instructed to remain active on cases in which divorces are pending until an order for temporary support is entered at circuit court. Within the last two years, the prosecutor 
and the Friend of the Court have rigorously pursued husbands who have left the state in order to avoid enforcement of support orders, and the recorder's court has extended full co-operation in this effort. The 1948 report of the Friend shows forty-five cases referred to the prosecutor for extradition, and nine completed.

If there were full and prompt co-operation between recorder's court and circuit court in support cases wherein both courts are active, most such escapes from all court control could be avoided. The difficulty of effective co-operation is at present a serious problem to both courts, for the nonsupport case loads at both courts are large. It is made more difficult by the fact that where the pre-court adjustment division is the only recorder's court agency with contact, the recorder's court has no legal hold over the defendant and can do nothing more then supply information regarding the whereabouts of the husband.

The juvenile court enforces support by trying to get the father to support his children without official court action, which, if finally necessary, consists of taking the children away. Where children are taken from the custody of a father who can support, the juvenile court can collect from the father sufficient money to reimburse the county for the care of the child. There is no machinery for the sharing of information, or for other co-operation, between juvenile court and any other support-collecting agency.

According to probation officers from juvenile, circuit, and recorder's court, as well as the Friend of the Court, retention of control over husbands unwilling to support their families is made particularly difficult because the wife, who is the best source of information as to the husband's whereabouts and financial circumstances, is often motivated by her desire to stay on relief so that she gives false information, remains silent, or becomes unavailable for a period of time sufficient to cover the husband's retreat. 
Sometimes she bribes the husband, with relief money, to remain out of the court's orbit.

The establishment and use of a central clearing house for daily exchange of information among court officers officially interested in enforcing family support seems to be an urgent need.

\section{Family supervision}

The probation departments of the circuit, recorder's, and juvenile courts and the Friend of the Court devote much time in supervising family relationships and conduct. The number of Detroit families being served by more than one probation officer is not known, because there is no systematic attempt by any probation department to ascertain the duplication, nor is there any machinery for doing so. The Friend of the Court estimates, however, that at least three fourths of its case load have had or now have contact with one or more other courts in the Detroit area. These contacts are usually in connection with a nonsupport or domestic assault prosecution at recorder's court, and if there are children, some history of juvenile court contact is likely.

The supervision case load of the women's division of recorder's court, which load consists of delinquent women many of whom have come into conflict with the law through unwillingness or inability to discharge their family responsibilities, consists to a substantial though undetermined extent of women whose children are currently under the jurisdiction of the juvenile court.

Social treatment of a family on probation involves, as Young points out, not only routine activities such as drafting budgets, arranging for proper diet, providing medical care, looking after school programs, establishing community contacts and so on, but also demands the establishment of "confidence, rapport, and a sense of security" such as will 
support a desire on the part of the family to "launch unabashed into a mutual exploration of the circumstances surrounding 'the trouble.' " ${ }_{42}$ Where a probation officer from the recorder's court, one from juvenile court, and a representative of the Friend of the Court are all trying to provide adequate social case work for a single family, each without consultation or knowledge of the program of either of the other two, efficient social treatment is unlikely to result. Even where one worker is able to achieve rehabilitation despite the misunderstanding, confusion, and irritation resulting from this duplication and lack of integration, the extravagance in use of court personnel and the waste of specialized talents is large.

And even where there is no present duplication, as where the domestic relations division at recorder's court has a long case history covering several years of probation and family supervision-and hence a valuable fund of experience with the family-it seems wasteful to have the juvenile court workers or the Friend of the Court start anew on the job of supervising the family life of the same family without the benefit of the case history.

\section{c. Factors Restricting Co-operation}

The present substantial disuse of the statutes for exchange of judicial personnel and for curing duplication of jurisdiction by waiver ${ }^{43}$ indicate that merely establishing methods of exchange of information, records, and personnel does not necessarily result in effective use of such machinery. Mere lack of channels for co-operating, therefore, is not the only cause of the absence thereof; equally important is the conscious disinclination of judges and other court personnel.

42 Pauline V. Young, Social Treatment in Probation and Delinquency (New York: McGraw-Hill Book Company, Inc., 1937), pp. 318-19 et seq.

${ }^{43}$ Supra pp. 226-227; 233-238. 
This unwillingness to co-operate seems to rest not on failure to recognize the areas of confusion and conflict but on a more compelling recognition of the fact that each of the courts in Detroit is now a highly complex organization with many functions and many employees, administration of which is made arduous by the size of the organization and of its case load. To encourage members of a staff to exchange material freely with members of other staffs is to risk loss of control and to jeopardize adequate disposition of one court's case load. The universal attitude seems to be that each is willing to co-operate, provided that he can control the extent and the results of mutual activity. Contributing factors to the disinclination are the loyalty of each court staff to its own organization, fear of political reprisals, and the professional reluctance of probation officers and others having access to confidential information to betray or jeopardize their clients.

Recent experiments in co-operation, such as that between recorder's court and the circuit court with regard to husbands unwilling to support their families, should be a demonstration of the fact that well-planned integration in areas of mutual activity can result in increased efficiency.

Without amending any statute, it would be possible to arrange for the routine sharing of records among Detroit courts, particularly among probation officers, upon a basis which would not hopelessly confuse the administrative responsibility for social treatment of cases on long-term supervisory control. If this could be done, the increased efficiency in handling cases, in economical use of court personnel, and in elimination of much useless duplication, would be tremendous.

Section 3. Effect of Diversity of Sources of Financial SUPPORT

Each of the courts operating in the city of Detroit draws upon more than one governmental unit for financial support; 
and each, in the course of daily business, collects large amounts of money for itself, for various governmental units and relief agencies as well as for litigants. The fiscal year of the county ends on November 30 of each year, and the published report of the county auditor goes to press before all department expenditures and receipts are accounted for. Hence the figures in the auditor's report are, to a certain extent, based on estimates. The fiscal year of the city, on the other hand, ends on June 30 of each year. Each of the courts operating in Detroit draws upon city funds to a certain extent and disburses certain collections to the city. The report of the auditor general of the city of Detroit, although it accounts for court funds, does not break down the departmental allocations so as to exhibit clearly the relationship between city and county funds in, for instance, the criminal division and the traffic and ordinance division of recorder's court. This circumstance, in addition to the difference in fiscal year, results in nearly complete confusion in attempting to obtain a general idea of the annual cost of maintaining the courts in Detroit for any single year.

To confuse the matter still further, each of the courts is in part maintained by state funds, returns a portion of its income to the state treasury, and is in part served by state employees-such as welfare investigators, tax investigators, and auditors-who spend much or all their time in the courts although they are not allocated to the court pay roll. The state fiscal year ends June 30 .

This sort of confusion, growing out of multiple sources of financial support, reaches its pinnacle in the recorder's court, which has attributes of a city, a justice, and a circuit court. The judges are paid partly by the county and partly by the city; the police detail is paid by the city; the probation department and court reporters by the county; the 
psychopathic clinic staff by the city; the clerk's staff by the city, but this staff includes a county auditor's officer who has the responsibility of conducting a daily audit of moneys received for the county by the recorder's court, and who in performing this task also contributes to the performance of the clerk's office duties. The clerk is paid partly by the city and partly by the county; he receives certain fees for work on county cases which he turns over to the city. The confusion was illustrated recently by the predicament of this official when he attempted to file the bond which he is required by statute to furnish. The city refused to accept it on the ground that the recorder's court is in effect a specialized branch of the circuit court, and the clerk is therefore in effect a county officer, or perhaps a state officer. The county and state also refused to accept the bond, and when the clerk asked the attorney general for an opinion, that officer replied that inasmuch as the clerk of the recorder's court is a municipal officer, he is not entitled to receive advice from the attorney general of the state of Michigan.

In fact, the financial affairs of the recorder's court are so inextricably intertwined between the county and the city that the county and city financial officers have entered into a working agreement which in general provides that all fines and costs collected by the criminal division shall go to the county, and all collections at the traffic and ordinance court shall go to the general fund of the city. A similar arrangement exists at the juvenile court between the county and city financial authorities with respect to the operation of the detention home. 
Section 4. Co-operation between Courts and Welfare Agencies

a. Number and Character of Welfare Agencies

Public welfare agencies

The State Department of Public Welfare is the official state agency which administers federal-state funds under the Social Security acts for old age assistance, Aid to the Blind, Aid to Dependent Children, and which administers general relief on a state-local fund basis without federal contribution. In addition to a widely departmentalized staff working directly under the state board, the Department works through local units such as the Wayne County Bureau of Social Aid and the Detroit Bureau of Social Aid, which are subject to some state control.

For instance, the children's division of the department of public welfare, working as a part of the state agency, has a staff housed in the juvenile court building which licenses children's boarding homes, child care and placement agencies, day nurseries and placement agencies, institutions for unmarried mothers, as well as places of juvenile detention. It consults with all public and private agencies on children's problems. Another group of trained child welfare workers, paid by the State Department of Public Welfare, and assigned to the juvenile court (under the appellation of county agent), make social studies of all adoptive families and make reports and recommendations regarding prospective adoptions. This group also supervises children in trial adoption homes, investigates guardianship petitions for the probate court, makes social studies on out-county cases, and supervises girls paroled by state institutions.

The Wayne County Department of Social Welfare, a 
county agency under the authority of the county commissioners, furnishes general and medical relief to indigent persons resident in Wayne County outside Detroit, and to all needy persons who are classified as "nonsettled"-i.e., recent migrants. Since there are large numbers of transients in Detroit, this responsibility is heavy.

The Detroit Department of Public Welfare is a charterestablished relief agency of the city which administers a social service program for all indigents in the city. Half the agency's funds are allocated from the state.

Other public agencies. Although there are other public agencies, such as the crippled children's commission and the police department, which share fields of common activity with one or more courts located in Detroit, a full enumeration would be tedious and of little informative value.

\section{Private agencies}

In addition to these public agencies and the many specialized bureaus and departments which branch off from each of them, there are numerous private agencies which deal extensively with family case work, child welfare and placement problems, chronic alcoholics, and mental cases.

The 1948 directory of the Detroit Council of Social Agencies, a voluntary association of all public and private agencies, which acts as a channel for mutual co-operation and planning, lists over two hundred active private social agencies in Detroit. Between these agencies and the courts there has developed a widespread daily co-operation in dealing with criminal, mental, juvenile, and domestic problems.

b. Areas of Co-operation with Welfare Agencies Welfare agencies concerned with mental cases

Social workers employed by the county investigate the financial status of all persons committed by the mental 
division of the probate court. The county and city currently employ a total of seven medical social workers who act as petitioners in mental cases reaching court from the psychopathic wards of the Wayne County General Hospital and the Detroit Receiving Hospital. ${ }^{44}$ In February, 1948, city medical social workers prepared and filed mental petitions involving II 5 patients in the psychopathic ward, and during that month, the workers appeared in probate court to testify in a total of 184 cases.

Child welfare workers from all public and private agencies often refer children with mental problems to the child study clinic at the juvenile court, which is able to supply diagnostic service and to obtain hospitalization for children whose parents or guardians are willing to agree to voluntary commitment. The board of education of the city of Detroit maintains a psychopathic clinic which employs a worker who often acts as petitioner in mental cases involving children alleged to be feeble-minded or psychotic, who have been referred from city public schools. These petitions are filed in the probate court. On April 2I, for instance, the writer observed a docket of twenty cases involving children alleged to be feeble-minded or otherwise mentally afflicted. Many of the petitions in these cases had been signed by the board of education's worker, who was in court. Many of the children on this docket, it was noted, came from broken homes.

\section{Welfare agencies concerned with criminal offenses}

The women's bureau of the Detroit Police Department, which employs about seventy-five policewomen, functions in a dual capacity. They investigate and prepare for court criminal cases arising out of sex crimes involving women and children under ten as well as those arising out of pro-

44 See supra p. 186 et seq. 
tective laws for women and children. Cases most often handled by the bureau include violations of ordinances forbidding children from peddling, soliciting, or offering services for hire; violations of theater, bowling alley, and dance hall ordinances regulating the conduct of minors unaccompanied by parent or guardian; violation of state child-employment laws; violation of laws prohibiting marriage of persons under a certain age; and commission of crimes such as contributing to the delinquency of a minor, indecent liberties and exposure, common law rape, statutory rape, and assault with intent to rape.

For many years, the head of the bureau, recently retired, was a highly trained and experienced social service executive, under whose direction the bureau developed policies of recruitment which required at least thirty hours of social service training for employment, and of investigation and referral which stressed the social service aspect of the work as of primary importance. The bureau "deals with problems disturbing to the persons involved on a case work basis." In this capacity, the department "acts as an investigating and sifting agency, referring cases to local agencies best adapted to give the service or treatment indicated." ${ }_{45}$ For instance, where an illegal sex act has resulted in pregnancy, the bureau decides whether the case is to be handled as a rape case or as paternity out of wedlock, though in either case the bureau will probably notify a social agency to look after the girl. If the legal proceedings are handled as paternity out of wedlock, the entire case is transferred to the department of public welfare, which employs a worker to act as liaison officer between social agencies and courts in dealing with cases of this type. ${ }^{46}$ In dealing with

45 Jessica Sinclair Kimball, A Manual of Court Function and Procedure FOR SOcIAL WORKERs, compiled under the auspices of the Council of Social Agencies of Metropolitan Detroit and the School of Public Affairs and Social Work of Wayne University, pp. 18-20.

46 See supra pp. 23I-232. 
sex crimes of a pedophilic nature, the bureau attempts to obtain psychiatric diagnosis by inducing the offender to obtain clinical service from the city or county hospital. ${ }^{47}$

The juvenile bureau of the Detroit Police Department consists of an inspector and staff selected for facility in handling children and in co-operating with social agencies, probation officers, courts, and other community agencies active in children's problems. The headquarters staff is stationed at the juvenile court building, and each precinct has a juvenile officer. The bureau handles boys between ten and seventeen. If an interview by the precinct officer with parents and neighborhood residents can solve the problem, no arrest is made. If arrest is necessary, the headquarters officers attempt to work out some means of handling the boy short of taking him to the juvenile court. One means often employed is that of placing a boy on "police visits," a method of case work or pre-court probation consisting of periodical home visits by a police officer from the Juvenile Bureau of the Detroit Police Department. These officers also work closely with group recreation agencies such as the Boys' Club, the Y.M.C.A., and others.

Alcoholics Anonymous is an agency devoted to the rehabilitation of chronic alcoholics, staffed largely by people who have themselves been rehabilitated. Many judges and court officials call the attention of this group to alcoholics who come before the court. Such references are not official, but take the form of highly confidential suggestions to an alcoholic that he attend a meeting of the organization, or to a worker that he get in touch with a certain alcoholic. Many judges and court employees supply clothing, emergency funds, employment suggestions, and other specific help in particular cases, through the Alcoholics Anonymous.

47 KIMBall, op. cit., p. 20. 
Other welfare agencies concerned with criminal cases. During observation at recorder's court, the judges requested Catholic and Protestant churches to supply volunteer workers to remain on duty at the court two days a week to find jobs, lodging, clothing, consultation, or group contact service for offenders who need such help. The clerk reports in $195^{\circ}$ that no Catholic chaplain appeared in response to this call, that the Protestant chaplain reported regularly for three months and has since then been only "on call," and that no Jewish chaplain appeared. The Salvation Army operates an industrial home for single men to which unattached misdemeanants are sometimes sent, and the Volunteers of America operate a supervisory service for men on probation or parole.

\section{Welfare agencies concerned with child placement}

Through its authority to license and inspect all boarding homes and institutions in which children are placed by any agency or court, the children's bureau of the state department of public welfare maintains some control over all child placement. Also, through its Aid to Dependent Children staff, the state agency is influential indirectly by referring to the juvenile court children of relief families whose home life is unsatisfactory to the Aid to Dependent Children workers.

In addition, there are several large private agencies in child placement. The Children's Aid Society is a nonsectarian corporate entity for temporary or permanent care of children of all races between the ages of three weeks and twenty-one years in their own homes when possible, or in boarding homes under the control and supervision of the society. It was organized to provide a means of co-operation with the juvenile court to see that children were placed with families or in institutions. The society handles some de- 
linquent children. When a child is placed by the juvenile court, the order places him with the society, which in turn selects a home and provides supervision. The court maintains control over the child, in such case, through the supervision extended by the society, which provides all facilities for necessary court and protective work. The society is in part supported by county funds, in part by the Community Chest, in part by private contributions.

A similar Catholic organization is the Society for St. Vincent de Paul, an international group of Catholic laymen for charitable service which has a child caring project in Wayne County, organized in order to co-operate with the juvenile court in caring for Catholic dependent and neglected children.

In May of 1948, I, 500 out of I,900 current neglect cases at juvenile court were in care of either the Children's Aid Society or the Society for St. Vincent de Paul. ${ }^{48}$

Other child placement facilities include Providence Hospital, which has a complete service for unmarried mothers and maintains a legal department to establish paternity and enforce support and maintenance for both mother and child. The Boys' Republic, a private agency established by the Ford enterprises, is an institution affording thoroughly supervised vocational training and institutional life for boys of average or unusually high intelligence, whether dependent, neglected, or delinquent. A similar service is now offered by the Catholic Boystown, established after the completion of field work.

The Wayne Community Survey, conducted in 1948 by the Citizens Survey Committee covering public as well as Community Chest supported agencies, shows that dependent and neglected negro children are not receiving care through the present placement agencies: out of 6,40 I children whose

48 Information supplied by statistician, juvenile court. 
cases were active in child care agencies supported by the Community Chest, only 566 were negro, although negro children are 18 per cent of the children in the community. The Children's Aid Society cared for 503 of the 566 children mentioned. ${ }^{4 \theta}$ Many authorities in Detroit believe that the negro community absorbs its homeless children more readily than the white community, so that there is less call upon the agencies for aid to negro children.

The same survey shows the need for over-all planning among agencies in the area of families with children who are being served by a family case-work agency but whose family life is disintegrating. There is found to be considerable confusion among agencies as to the duties, in such cases, of family case-work agencies and of child placement agencies. The same area is further confused, the Community Survey states, by the fact that "proper relationships have not been developed between the Police Women's Division, the Juvenile Division of the Police Department which handles boys' cases, and the public and private agencies handling protective cases."

Welfare agencies concerned with family case work

Not only does each of the public agencies maintain a complete family case-work service, but there are a large number of private agencies in this field, including the Society of Good Neighbors, the Salvation Army, the Family Casework Agency, the Family Service Society, the League of Catholic Women, and others. For instance, the juvenile court furnishes office space to volunteer workers from Catholic and Protestant groups called the Big Brothers and Big Sisters, who do limited probation work for the court.

49 Wayne Community SuRvey at p. 33.

50 Ibid., p. 29. 


\section{Welfare agencies concerned with family support}

In Wayne County in 1947, I6,8I7 cases were aided financially through federal-state old age assistance, 6,739 through federal-state Aid to Dependent Children, 342 through federal-state Aid to the Blind, 1,998 through the county relief program, and 12,500 through the Detroit department of public welfare, the city agency. Total expenditures for all these programs were $\$ 23,973,258$ in direct relief through public agencies alone. ${ }^{51}$ Note that the figures do not include unemployment compensation, railroad or other publicly-administered retirement annuities, or any of the service assistances such as Veteran's Administration.

The relief case load of all agencies is at this time increasing rapidly: for instance, the research director of the Council of Social Agencies of Metropolitan Detroit reports that the case load of the city agency for 1948 represented a 406 per cent increase in families receiving full relief over the comparative load in 1942 . Family cases receiving supplemental aid have increased 323 per cent during the same period. $^{52}$

Private agencies which supply financial relief include United Jewish Charities, the Polish Aid Corporation, the Servicemen's Bureau, several Catholic agencies, and relief committees operated by various unions.

It is in the area of family support cases that the welfare agencies and the courts located in Detroit experience the most need for mutual understanding and integration, for where a court is able to enforce the liability of the husband or parent to support, the welfare agencies are relieved of the necessity of supplying further financial relief to the family, and in some cases are reimbursed through the courts for relief already supplied.

51 Wayne Community Survey (1948), "Family Casework Service," table 8. 52 Statistical report of the director. 
c. Methods of Co-operation with Welfare Agencies

\section{Probate Court: aid to dependent parents}

Very similar to the recorder's court pre-court adjustment division's activities in screening out criminal nonsupport cases in which no formal complaint has been made is the duty performed for the probate court by the aid to dependent parents division, which performs a similar service for cases in which public relief authorities seek to file petitions in probate court to enforce the liability of children to support parents. Technically a part of the prosecutor's office, the division operates solely as a pre-court screening agency in which relief authorities, in investigating applications for aid by aged persons, have found relatives who are in the jurisdiction of the Probate Court of Wayne County and who appear to be able to support their parents.

Until four years ago, the division was a part of the county auditor's investigation unit; at that time, the old age assistance case load contained enough cases ${ }^{53}$ in which relatives could be made to support their parents or to reimburse the welfare authorities through the probate court, so that transfer of the division to the prosecutor's office took place. Its entire staff of four are professional case workers; none are lawyers. Most of its cases are referred by the old age assistance staff of the county agency, some by private agencies, some by recorder's and circuit court, some by newspapers, none by the Detroit department of public welfare. Upon receiving a case, the division conducts its own investigation to confirm the ability of resident children to contribute to their parents' support, to persuade them to make a partial contribution, or to work out some other solution. Frequently the cause of difficulty is friction caused by crowded living conditions. In such

${ }^{53} 401.2$ and 400.77 CoMp. Laws (1948); 16.122 and 16.477 Mrch. STAts. AnN. 
cases it is often possible to place the parents in private homes through private social agencies, or to obtain medical attention through one of the public hospitals. The division works out the best solution possible on the basis of voluntary contributions and refers the case back to the original agency with its recommendations for the amount of public assistance necessary to piece out the sums contributed by the children. In such cases, the public agency then proceeds with an application for a partial pension. Where the division learns that no financial support can be obtained from the children, the case is returned to the referring agency and the division closes its file.

Where the children can but will not support their parents, the division institutes action in the probate court to enforce support. Petitions are presented, in court, by the director of the division, who is not a lawyer. During 1947, there were approximately forty court cases, some of which represented appearances in response to show cause orders previously entered by the court. As in the pre-court adjustment division at recorder's court, and the Friend of the Court at circuit court, the division collects all money on cases being actively serviced by it.

\section{Recorder's Court}

During final revision of this study, the city investigated its active relief cases. During the first few weeks of investigation, and as a result of it, fifty-nine husbands whose wives had received city welfare were found guilty in recorder's court of nonsupport. Ordinarily, men convicted of nonsupport in these circumstances are placed on probation, with repayment of relief and continued future employment made conditions of probation. Repeated failures to continue in employment, however, often result in the imposition of jail sentences for violation of probation. 
Incarceration in these cases has the disadvantage of throwing the burden of support back on the relief authorities. There are also several recent convictions for fraud on welfare authorities, growing out of the same investigation.

So numerous are cases in which family relief and criminal actions for nonsupport coincide that the Detroit department of public welfare and the Wayne County department of social welfare each employs a full-time worker to act as liaison officer between the recorder's court and the respective relief agencies. Each worker handles cases which have come to the attention of his agency because of some recorder's court action which affects relief-as when the court is trying a man for nonsupport who might be able to reimburse the relief authorities. In such a case, the worker attends court, consults with the judge as to the contents of the probation order, and perhaps gives testimony about the service extended to the family by the agency. This service usually includes financial assistance and family case work and possibly includes child welfare service. The worker currently assigned to the recorder's court by the city agency states that his case load averages about 500 cases a month. Not all of these represent actual trials, of course; in many, the recorder's court contact is in the pre-court adjustment division, the psychopathic clinic, or one of the supervisory probation establishments.

\section{Circuit Court}

Although the report of the Detroit department of public welfare for February, 1948, shows 346 cases in which relief supplemented alimony, ${ }^{54}$ so far as can be learned there is no city worker regularly assigned to the Circuit Court of Wayne County ${ }^{55}$ however, members of the Friend of the

54 At p. 6.

55 Subsequent to the period covered by the survey, the presiding judge of 
Court's staff, upon learning of such supplemental relief, often call the court's attention to it. In some cases the court's order is as large as the husband's earning capacity permits, but still below the recommendation of the Friend as to the sum necessary to take adequate care of the family. In other cases, however, the relief which supplements the courtcollected support money brings the family income above the amount determined as necessary by the court. In these latter cases, the supplemental relief amounts to a usurpation of the court's authority to determine and collect support for the family.

At this writing the county relief agency has assigned a full-time worker to the Circuit Court of Wayne County. This assignment occurred recently, as the result of a very large number of cases encountered at circuit court in which the court has found it difficult or impossible to enforce its orders for alimony or child support because the wife, once she is receiving relief, ceases to co-operate with the court in proceedings to enforce support. The number of such cases, in fact, is related to the practices recently adopted by the Friend of the Court whereby all payments of alimony and support must be made to the Friend's office, which institutes automatic proceedings for contempt when payments are not promptly made, whether or not the wife has complained. The county relief worker at the court receives reports from the Friend or the trial judge concerning cases in which both court and relief agency are actively trying to see that the family receives support, and she co-operates with the court in attempting to work out a policy which is satisfactory to both the court and the agency. By current policy, in the trial of any proceedings concerning the payment of money as directed by the circuit court in a domestic

the circuit court was able to obtain the assignment to his court of a full time worker from the Aid to Dependent Children's staff of professional child welfare workers. 
relations case, the judge makes it a point to ascertain whether the family is receiving financial assistance from the relief authorities. Where it appears that such is the case, the judge continues the hearing, writes a letter over his own signature to the agency or agencies concerned, and withholds final action on the legal proceedings pending the receipt of information from the agency.

In child support cases, the circuit court experiences its greatest difficulty in co-operating with the public welfare agencies. The "ADC," or Aid to Dependent Children program, is administered by a state-paid staff of highly trained child welfare case workers some of whose policies are suggested by the United States Children's Bureau. At this writing, no $\mathrm{ADC}$ staff member has been assigned to the circuit court. The function of this agency is to extend regular aid including support to dependent children, in such a manner as its case workers determine after giving expert attention to each case. Many of its children come from broken homes. In many ADC cases, therefore, the circuit court also has the function of seeing that the children receive support. Co-operation is difficult, according to the circuit judges and the Friend of the Court, for these reasons: (a) extension of financial relief by the ADC often makes legal pressure on the fathers very difficult, because it removes the economic pressure which causes the mother to be willing to co-operate with the court in enforcing the father's legal liability to pay family support; (b) the amounts found necessary for child support by the Friend of the Court, and the kind of family case work offered by the Friend, often differ from the amount of support and the kind of case work provided by the $\mathrm{ADC}$; (c) there is no means, under current practice, whereby routine consultation takes place between circuit court personnel and ADC personnel with regard to cases serviced by both, so that there is much 
duplication of effort, mutual irritation, and many cases in which the efforts of each inhibit or even cancel out those of the other.

In bastardy and civil paternity cases, ${ }^{56}$ the court is required to make an order for support which will indemnify the county for the mother's confinement expenses and the child's maintenance. This amount, once the responsibility of the county relief authorities, is now collected through the Friend of the Court, which is also charged with the responsibility of investigating the facts and reporting to the court. The amount of the order is the subject of frequent discord, for often the determination of the court on the recommendation of the Friend of the Court differs from the amount determined by the child welfare or family case workers, or both, assigned to the case by various public relief agencies. In one such case, the writer attended a hearing in circuit court which was attended by six different case workers, all of whom had some official connection with the case. Another observed case, which is cited as an example of the disagreement between court and public welfare agencies, involved the mother of an illegitimate child. The mother, a trained stenographer, resided with her parents, who were of modest but stable income. The judge made an order, as recommended by the Friend, based on a requirement that the girl should go back to her job and leave the child in the care of its grandmother during her working hours; this arrangement was desired by the grandparents and agreed to by the employer. The child welfare case worker for one of the two public agencies which was active on the case, however, did not approve of this method of handling the case; she held it to be bad family case work and bad child welfare. She required the girl to set up a separate establishment for herself and the child, and to give

${ }^{56} 722.601$ et seq. Comp. Laws (1948);25.451 et seq. Mich. Stats. Ann. 
all her time to the baby. The cost of this plan was beyond the means of the baby's father, a married man with a wife and several small children to support. The position of the case worker was that the amount necessary to indemnify the county in this case was the amount required to handle the case as the county family case worker under the supervision of the state child welfare worker wanted it handled, and she proposed to supplement the court order by relief to bring it up to the sum so required. The position of the court was that both the amount of support and the function of supervision were the province of the court, and that the public welfare agencies had no legitimate position since the amount ordered by the court constituted an amount adequate to handle the case without the necessity of any financial assistance from the relief agencies.

Such problems as these are often multiplied by the presence in the case of several case workers from various priva'e welfare agencies and perhaps a juvenile court probation officer, if the unmarried mother is a juvenile. In such a case, too, there might be a recorder's court probation officer concerned where the man had been prosecuted for contributing to the delinquency of a minor.

\section{d. Central Registration Bureau}

The central registration bureau is an official clearing house maintained by the Detroit Council of Social Agencies for the exchange of information about cases. Members of the police force or of probation staffs or the Friend of the Court's office may find out by telephoning the bureau the public and private agency contacts and the dates thereof on any family or individual. The data are recorded on cards filed by the surname of the family head or single person receiving service. Various court departments make use of this bureau. 
The pre-court adjustment division of the probation department at recorder's court currently reports all its cases to the bureau, and reports to the bureau all cases coming into the division. It should be borne in mind, however, that the division is limited in activity to seeing that the wife receives support-from the husband directly if possible, through the division as a general rule, and by means of criminal action for nonsupport as a last resort. Precluded by its limited function from doing any family case work, it can make no real use of information obtained from the bureau. On the other hand, the reporting of this division's cases to the bureau should prevent disbursement of public assistance to many applicants who are in fact receiving support collected by the division.

Other divisions of the probation department at recorder's court do not report their cases to the bureau except occasionally, and make no routine attempt to check with the bureau for information about previous welfare agency contacts. The investigating probation officer's technique in assembling a case history so far as welfare agency contacts are concerned appears to be limited to reading the police department record which is always placed on the probation officer's desk by a police officer, and which in certain types of cases may include certain principal welfare agency contacts, as well as juvenile court contacts which are not directly available to the officer from the juvenile court.

Recorder's court probation officers who are supervising cases appear to make no attempt to get in touch with agency case workers who are serving the same families.

The Friend of the Court does not report its cases to the bureau, but frequently consults the bureau to obtain information about the activities of the public welfare agencies with reference to family case work or family support activities. 
Other probation departments of courts located in Detroit appear to follow the same general policy; they do not routinely report their own cases to the bureau, and they inquire of the bureau only in infrequent cases. The writer was able to find no example of actual consultation or cooperation between a probation officer and a case worker who were working on the same case.

The psychopathic clinic at recorder's court, on the other hand, which makes a social study of each patient, currently inquires of the bureau with reference to each patient, and frequently follows up the inquiry by getting in touch with department heads, case workers, or court officials who have had some contact with the patient or a member of the patient's family which might bear upon the social study.

In a previous study, statistical tables from the bureau were used as a basis for the conclusion that there is no serious overlap or duplication as between the public and private welfare agencies and the courts operating in Detroit. ${ }^{57}$ This writer has attempted no examination of the bureau's records, for the reason that observation and interview indicate that the reporting by court departments of their cases to the bureau is infrequent and haphazard, and that the use made of such information as is obtained by court departments from the bureau is negligible, except as an aid in diagnosis by the psychopathic clinic at recorder's court and as a means of preventing fraud on welfare authorities by women already receiving support through recorder's court and/or the circuit court. The practices encountered during the year and a half of field work for this study are such as would make such statistics entirely misleading. More important, it is apprehended that the disuse of this bureau, which might operate as an integrating force, indicates the unwillingness of courts to co-operate with public

${ }^{57}$ Lapp, Cooper, and Dawson, op. cit., pp. 165-172. 
welfare agencies and vice versa, and that it tends to indicate that the size of the area of overlap and confusion, of duplicating and conflicting service, is not known to anyone because of the lack of co-operation under current practices.

e. Areas and Extent of Overlapping between Courts and Welfare Agencies

With respect to the actual amount of duplication and overlap, the writer had knowledge, through reading litigation or probation files, or through courtroom or other court observation, of an aggregate of at least two hundred cases in which one or another kind of inefficient or irresponsible domestic behavior was the immediate cause of the court contact. Of all such cases examined or observed, there were less than a dozen which did not show at least one other agency or court contact prior to or concurrent with the contact of the court being observed. In the area of family case work, nonsupport, and child welfare cases, there were more often than not several public and private welfare agencies and at least two courts having current contact with the case. This is even more impressive in light of the fact that no consistent attempt is made by these courts to obtain systematic information about welfare agency or other court contacts.

The results obtained in terms of family rehabilitation are likely to be poor when more than one probation officer is trying to provide family case work with budget supervision for the same family, and still worse when several case workers from public and private agencies are added, so that often half a dozen case workers are at work on a family, each with the duty of extending minute supervision over the financial, social, and domestic behavior of the entire family. 


\section{Chapter VIII}

\section{Summation and General Conclusions}

$\mathrm{H}$

AVING examined the trial courts operating in the Detroit metropolitan area with a view to enumerating those problems which are thought to exist because of the metropolitan nature of the community, it may be useful to summarize here the general purport of some of the material set out at length hereinabove, insofar as the same relates to the precise result sought by this study.

I. Like any metropolitan community, Detroit is confronted with problems of court operation differing from those of other courts by reason of the density and mobility of the population, and the displacement of the stable elements of population. The case loads contain disproportionately large numbers of mental, chronic alcoholic, criminal, traffic, and domestic conflicts cases. ${ }^{1}$

2. The greater size of the case loads and the types of cases comprising them necessitates large court staffs, elaborate machinery for handling dockets, and the development of specialized administrative agencies within the courts for handling sociolegal and medicolegal problems. Primarily because of the widespread and growing use of such administrative agencies, the orbit of the court extends in many cases over a long period of time, during investigation and supervision.

3. The multiplicity of governmental units found in the metropolitan community is reflected in the complication of courts operating there. Among the areas of confused jurisdiction due to the creation of coexisting independent courts

${ }^{1}$ Supra pp. 16-30; Chaps. III and IV, passim. 
which have developed without comprehensive planning for the locality to be served, are these: the large number of small claims brought in the higher rather than the lower court, lack of authority of juvenile court over cases in which children are alleged to be mentally afflicted, lack of jurisdiction in recorder's court to diagnose and hospitalize chronic alcoholics, the small fringe of criminal jurisdiction retained by the Circuit Court of Wayne County, and the confused situation with regard to wayward minors. The most serious area of duplication and conflict, however, involves domestic cases with family or sex problems, as to many of which any of several courts may exercise jurisdiction. $^{2}$

4. The multi-judge court is a typically metropolitan feature. Such a court calls for the use of an administrative or presiding judge to secure effective court control over its large and highly departmentalized staff. The use of a longterm presiding judge with centralized control of all aspects of the work of the court appears to result in more efficient operation than the rotating of the presiding judgeship at short intervals. ${ }^{3}$

5. The most serious problem of judicial administration encountered in the Detroit area is the lack of co-operation among courts, particularly in handling family cases. Such machinery as does exist for exchange of judicial personnel and for sharing of equipment and facilities is in disuse. With the notable exception of the Friend of the Court at the circuit court, a strong policy of local autonomy pervades each court and each department within each court. Among the most harmful results of the lack of integration of courts operating in the area, the following may be named: the existence of five different systems for obtaining juries despite

2 See table I, p. 6; pp. 226-232.

${ }^{3}$ Supra pp. 75-77;82-84; 194-203; 205-213; 217-218. 
270 METROPOLITAN COURTS: DETROIT AREA

the small number of jury trials taking place; diversity of sources of financial support; the independent existence of three different probation departments and the Friend of the Court, with no means of co-operating, although their family supervision and support case loads contain much overlapping and duplication; the nonexistence of statistical records in some courts and the lack of an integrated plan for keeping records and statistical material. ${ }^{4}$

4 Supra pp. II8-129; 234-248. 


\section{APPENDICES}




\title{
APPEndiX A
}

\section{A Chancery Pre-Trial Statement}

\author{
STATE OF MICHIGAN \\ In the Circuit Court for the County of Wayne \\ in Chancery
}

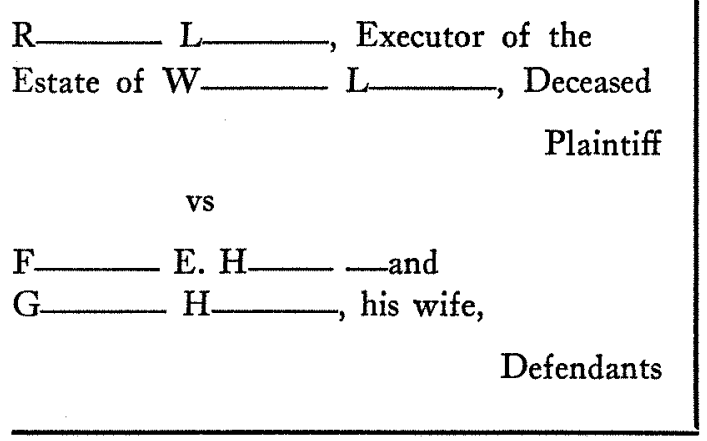

No. 400,802

Proceedings had before the Honorable Ira W. Jayne, Circuit Judge, in the above entitled cause, on Wednesday, April 14, 1948.

Appearances

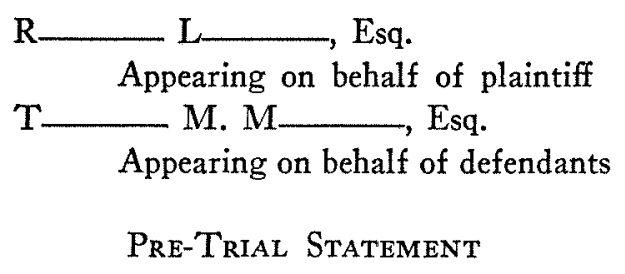


This is a bill in equity brought by the Estate of W L _ Deceased, for a specific performance of an alleged contract to purchase land specifically and correctly described in the bill of complaint and by reference made a part of this pre-trial statement.

The defendant admits the execution of the agreement but claims that it was for security for money loaned and that the money has been paid back in full, which raises the issue of law and fact for the trial judge.

The plaintiff will offer in evidence a deed marked Pre-Trial Exhibit A from the State Land Office Board to the defendant $\mathbf{F}$ $\mathrm{H}$ _ which is admittedly lawfully in the possession of the plaintiff.

At the pre-trial hearing the plaintiff also offers Exhibits $A$ and B, the same being photostats of a check and a receipt, the originals of which are marked Pre-trial Exhibits B and G. The execution of these the defendant admits.

By way of defense, the defendant offers Pre-trial Exhibit D, photostat of which has been filed, as proof of his contention that the transaction was one of security for a loan and that the same has been repaid.

Pre-trial Exhibit D on its face discloses that the words "I will return his bill of sale for five lots" is a crowded entry. Counsel for the defendant admits that all of Pre-trial Exhibit D is in the handwriting of the defendant $\mathrm{H}$ _ $\mathrm{He}$ admits that the above quoted sentence was written by $\mathrm{Mr}$. $\mathrm{H}$ with a different pen, but insists that it was a part of the receipt signed by the plaintiff $\mathrm{W} \longrightarrow \mathrm{L} \longrightarrow$, added in his presence and with his consent.

The plaintiff on the other hand admits the signature to this receipt of the Plaintiff W$\mathrm{L} \_$_. The extent and meaning of this receipt is an issue for the trial judge.

The defendant $\mathrm{G}$ _ $\mathrm{H}-$ is made a party because of a possible dower interest in the real property of the defendant F. $\mathrm{H}$

Circuit Judge 


\section{APPENDIX B}

\section{Organization and Personnel of Courts Operating in Detroit (1948)}

Circuit Court of Wayne County, Michigan

Judicial personnel:

18 judges, $I$ of whom is presiding judge

Quasi-judicial personnel:

4 circuit court commissioners

Friend of the Court occasionally functions as referee

\section{Clerical staff:}

A. County clerk (in capacity of clerk of court)

I secretary to clerk

I administrative assistant to clerk

I deputy clerk (as general assistant)

a. "Front Counter" staff: 4 clerks handling commencement of suits, information, entry

b. Cashier's staff: I cashier

$$
\text { I assistant }
$$

3. Records staff litigation files):

I supervisor

I assistant

I I clerical employees

3 journal clerks

d. Courtroom clerks: 22

e. Court stenographers: 18

B. Circuit court commissioners' staff:

I office clerk

I5 assistants to office clerk

4 courtroom clerks

C. Assignment clerk's staff (responsible to presiding judge) : 4 assistants

I librarian 
Administrative agencies:

A. Probation officer's staff:

I assistant chief

I director women's division

9 probation officers

9 clerical and stenographic employees

B. Friend of the Court's staff:

8 chief assistants

Investigation department:

3 supervisors

22 investigators

I5 stenographic and clerical employees

Alimony complaint department: I2 employees

Stenographic division: I4 employees

Cashier's department:

I cashier

14 assistants

Other:

I 8 deputy sheriffs are assigned to devote full-time service to the court. They act as courtroom assistants to the judges and clerks.

Total personnel: Approximately 240.

\section{Probate Court of Wayne County *}

Judicial personnel:

5 judges, of whom $I$ is presiding judge.

Clerical staff:

Register (executive officer for all departments).

I assistant register assigned to certified copies, and 3 typists

I assistant register assigned to publications, and 3 clerks

I assistant register assigned to calendar and 6 employees

I secretary to the register

5 courtroom secretaries

5 court reporters

Order department staff: 15 employees

* Juvenile court is separately diagramed. 
"Long Counter" staff (entry, information, forms, bonds) : 5 employees

Claims department: I employee

"Short Counter" staff (files, records): 3 employees

Inheritance tax examiner

Administrative agency: Mental division (responsible to register)

I head

I assistant head

I matron

3 typists

5 process servers

Other: No figures available on number or frequency of use of such occasional assistants as referees, assessors, physicians in mental cases.

Total known personnel: Approximately 75 plus

\section{Juvenile Court of Wayne County}

Judicial personnel:

I full-time judge

\section{Quasi-judicial personnel:}

I official boys' referee

The chief clerk acts as referee in traffic cases

The head of the boys' department acts as referee in boys' cases

The head of the girls' department acts as referee in girls' cases

The head of the dependent and neglected children's department acts as referee in cases arising in that department

The register acts as referee in traffic cases

Clerical staff: Register is executive officer for the court

I secretary-reporter for judge

I secretary-reporter for relief judges (see Other, infra).

I secretary for the register

I director of statistics and research with I assistant

I chief clerk with Io employees

I stenographic pool with 20 to 22 phonotypists 
Administrative agencies: (responsible to judge)

County agent (investigates adoptions)

I assistant

4 social workers

I worker loaned by State Department of Social Welfare

Boys' department: Head is chief probation officer of department

2 assistants

20 probation officers

Girls' department: Head is chief probation officer of department

I assistant

14 probation officers

Dependent and neglected children's department: Head is chief probation officer of department

I assistant

I4 probation officers

Clinic for child study: I director

3 psychologists

5 social workers

3 clerks

6 part-time psychiatrists

\section{Other:}

I judge from the probate court comes in two half days a week as relief. During the latter portion of the field work, a second judge came in once or twice a week as the case load increased.

The court operates a detention home with a superintendent under whom are:

I boys' supervisor with 35 employees

I girls' supervisor with 35 employees

I director of education and 7 teachers (city employees supplied by the Detroit Board of Education but subject to the control of the court)

Total personnel of court: Approximately $1 \mathrm{r} 5$

of detention home:

grand total 


\section{ReCorder's Court}

Judicial personnel: 10

Clerical personnel: Clerk is executive officer, with staff of:

I secretary

I bail bond bureau clerk with 2 assistants

I librarian

I warrant clerk with 4 assistants

I I court reporters

IO courtroom clerks

I presiding judge's clerk

6 assistant clerks assigned to docket, journal, calendar, index, statistics, files, subpoenas, appeals, and miscellaneous

\section{Administrative agencies:}

Probation department: I chief probation officer

I assistant chief probation officer

Pre-court adjustment division with 1 director and 3 probation officers

Domestic relations division with I director and 8 probation officers

Women's division with I director and ro probation officers Men's division with staff responsible directly to assistant chief probation officer and divided into:

Pre-sentence investigation section with $\mathrm{I}$ supervisor and Io probation officers

Supervision section with I supervisor and I 7 probation officers

I liaison employee working betwen investigation and supervision sections

Psychopathic clinic with I director

2 psychiatrists

I medical doctor

5 psychologists

6 typist-clerks

Other: A police detail of 52 is assigned to full-time service. They act as courtroom attendants, as escorts to prisoners, and in other capacities under the control of the courtroom judge and his staff. 
Total personnel: Approximately 130. The psychopathic clinic and probation departments serve both misdemeanor and felony divisions, and their services are available to the traffic court.

\section{Traffic Court}

Judicial personnel: 2

Quasi-judicial personnel: 5 referees

Clerical: The chief deputy clerk is executive officer of the court. His staff consists of :

5 court clerks for the referees

2 court clerks for the judges

2 secretary-reporters for the judges

I secretary for the chief deputy clerk

I administrative assistant

I accountant

2 statisticians

I head clerk in charge of a staff consisting of:

22 clerks assigned to counter, docket

18 stenographers

8 cashiers

20 mail clerks

I 5 clerks assigned to accident prevention bureau records

I head clerk in charge of a staff consisting of :

I principal clerk in charge of

23 clerks assigned to index, coding, and records which are sent to Secretary of State

I principal clerk in charge of

I I clerks assigned to information, calendar, ledger, clearance

5 statisticians

4 clerks assigned to various tasks as need arises

Total personnel: Approximately i 50.

(Violations bureau staff and accident prevention bureau staff are part of the police department, not regarded or administered as part of the court.)

Court of Common Pleas of Detroit

Judicial personnel: 9 judges, 1 of whom is presiding judge 
Clerical personnel: Clerk of court is executive officer, with staff consisting of:

9 courtroom clerks

5 clerks assigned to partial payment

5 clerks assigned to assignment

4 clerks assigned to journal

4 clerks assigned to file preparation

9 clerks assigned to docket

I deputy clerk in charge of:

3 clerks assigned to alias

I clerk assigned to filing

I clerk assigned to control

I clerk assigned to counter

3 clerks assigned to summons

3 clerks assigned to issue

3 clerks assigned to returns

I deputy clerk in charge of:

2 stenographers

6 bookkeepers

4 clerks assigned to index

3 cashiers

I deputy clerk in charge of:

I clerk assigned to summarize the activity of each judge in his courtroom, and to prepare daily and monthly reports from this data

Total personnel: Approximately I39 


\section{APPENDIX C}

\section{Hearing on Petition to Commit Alleged Insane Person*}

$\left.\begin{array}{l}\text { State of Michigan } \\ \text { County of Wayne }\end{array}\right\}$ ss.

IN THE MATTER OF

$\mathrm{V}$ $\mathrm{V}$ AN

Alleged Insane Person
In the Probate Court, HoN.

Presiding.

No. $357-84 \mathrm{I}$

Thursday, April 8th, 1948 .

Present: Hon. Judge of Probate

Mr. B

Application for Admission

Mr. B : The patient is present, your honor

$\mathrm{L}$ — $\mathrm{V}$ _ being first duly sworn, took the witness stand and testified as follows:

EXamined by the Court:

Q. Are you $\mathrm{L}$ $\mathrm{V}$

A. Yes sir

Q. You are the husband of $\mathrm{V}$

A. I am

Q. Your wife is a resident of Detroit

A. Yes sir

Q. She is about thirty one years of age

A. Yes sir

Q. During a recent period, has she shown evidence of mental difficulty

A. Yes sir, I think she has

* Complete transcript of hearing on petition to commit V $\mathrm{V}$ an alleged insane person, before Probate Court of Wayne County, Michigan, Thursday, April 8, 1948. 
Q. Prior to the I Ith of March when you made this application, did she want to sell everything in the house

A. I wouldn't say "everything"

Q. She did want to sell the gas stove

A. Yes sir and the refrigerator

Q. Did she neglect herself and her children

A. Yes sir, she did

Q. Did she make the observation that the children needed only a candy bar for a meal

A. Yes sir, many times

Q. Was there a period when she would sit and stare into space

A. Yes sir

Q. For long periods

A. Between a half hour or an hour at a time

Q. Did that seem to you what we might call "bizarre"

A. Yes sir

Q. Did she seem to have a persecution complex

A. Yes sir; we have recently purchased a new home out there and every once in a while she felt that the neighbors were persecuting her. I think the neighbors are very nice; everyone seems to mind their own business. She seemed to think they were doing her harm; inasmuch as it is a new neighborhood and there is still a little bit of dirt around and the children go out and come back dirty and she complains that the neighbors were the cause of it

Q. What is your occupation

A. I am an engineering clerk

Q. With what company

A. The Cononial [sic] Broach Company; I had been a funeral director and embalmer when I had my own business for a while

Q. Are you in a position to pay for her support at an institution

A. No, I am not

Q. Is her mother or sister here

A. Her sister is here

$\mathrm{U}$ G_ , being first duly sworn, testified as follows:

\section{Examined by the Court:}

Q. You are Mrs. G

A. Yes, sir, I am

Q. Were you born in Italy and also your husband

A. My husband was, I was born in Detroit 
Q. And your sister was born where

A. In Detroit

Q. What is her education

A. She went to the Ioth or I Ith grade

Q. You heard the husband testify

A. Yes sir, I did

Q. Do you feel from your own knowledge that those facts are true

A. They were very true; he didn't imagine that; he is a good husband; he has been very good

Q. Do you feel that your sister really is in need of hospital care

A. Yes sir; she has done things and said things that were not right Dr. L_ $\mathrm{L} \longrightarrow$ being sworn, testified as follows:

EXAMined by the Court:

Q. Doctor, have you examined the patient, $\mathrm{V}$ V

A. I did, yes

Q. To-day

A. Yes sir, to-day

Q. Can you tell us about the results of the examination and some of the details and episodes

A. This patient shows absolutely no evidence of any in-sight of her own; she stares into distance and has lost a great deal of responsible, sense of responsibility and she has ideas of persecution. She is firmly convinced that the neighbors and relatives are jealous and are trying to harm her. There is no question in my mind that this patient has a psychosis which probably is of a paranoid type and she should be hospitalized and receive treatment

Mr. B_ I will prepare a blank

Dr. I B. S__ being first sworn, took the witness stand and testified as follows:

\section{EXamined by the Court:}

Q. You are a physician and surgeon and psychia-trist [sic]

A. I am

Q. Do you specialize in psychiatry

A. I do

Q. Have you interviewed V
A. I have
Q. She is present here in court
A. She is 
Q. Can you tell us the result or the details, more or less, of your examination and the results that you arrived at from talking to her

A. In my opinion this woman is very sick from a psychiatric stand-point [sic]. My conclusion is based upon the history obtained and from my interview with the patient. She apparently has behaved very peculiarly in that she has lost interest and has been unable to take care of her home and children properly. She is unable to manage the children and frequently calls on her physician asking advice as to what to do. She has confined herself to the house because of fear of going outside saying when she goes outdoors, the people in the neighborhood watch her and talk about her. The reason given is that she is more beautiful and younger and they talk about her. She has a total lack of insight and unable to realize that she is sick woman. My diagnosis is schyzophremia [sic], paranoid type and is in need of prolonged hospitalization and treatment

The Court: Schyzophrenia; that would mean a split personality

A. Yes sir

Q. Can you tell us what the characteristics of what you call it, is

A. Yes; it is a type of disease of an individual having certain ideas in her mind and which she firmly believes but which are not true; therefore, they come in conflict and it runs along because of the difference of opinion and no amount of talking would convince them that their opinion is wrong. This patient shows a very lack of insight; they have visions and hallucinations but this woman hasn't reached that stage yet; that is the reason $I$ think she should have the benefit of treatment

Q. Would the so-called shock treatments be of benefit

A. I believe in this case, I believe it would be better for her to have the insulin shocks

Q. You do, without hesitation, recommend hospital treatment and care for her psychotic condition

A. I certainly do

$\mathrm{V} \longrightarrow \mathrm{V} \longrightarrow$, being first duly sworn, testified as follows:

Q. You are V $\mathrm{V}$

A. Yes sir

Q. You heard what the doctors said

A. The best I could, yes sir

Q. Are you willing to co-operate to have treatment for your condition

A. If it is necessary, yes 
Q. You don't think it is necessary

A. No; I think I need a little rest at home; with the children growing up, I can't be washing and ironing and doing twice as much laundry work as I have been besides caring for the children. They are of school age now - they are not babies any more; they want to get dressed up and go places and see things. All I would do is take care of myself very well and take care of the children and have some one do my work. I can wash dishes and cook and sew but I can't do the heavy work like I have. The only thing wrong with me is I need a little rest. I have no help; my husband don't help any. $\mathrm{He}$ did the heavy shopping and I was thankful and he was satisfied

Q. You don't feel that-

A. I have been in the hospital for two weeks and I am on my own. I wait on six hundred people when I can stand it with the rest of the women and I can cook and I consider myself a working girl. I like to keep myself occupied. I don't get any night rest. They are crying and screaming and there is no rest for me; I could get some rest at home I would say it was all right for two weeks but I don't think I am that sick and I don't belong there. I have no aches and pains; I can stand on my own feet; all I need is rest; I should be treated like a mother of two children who is raising them

The Court: I must admit you make a very good case for yourself but I feel, however, that the recent amount of hospital care has improved your condition and a further period in the hospital will be beneficial

A. Well, my children need me and I think I could take care of them much better; I have kept them healthy; I must have shown my duty more than a lot of others

THE CourT: I have to be governed by the weight of the evidence here and $\mathrm{I}$ am inclined to think that the judgment will be that you be committted to Ypsilanti with temporary detention at Wayne County General

Mr. B She is at Ypsilanti now

The Court: That you be committed to Ypsilanti as a public charge 


\section{Bibliography}

Abbott, Edith. Public Assistance. Chicago: University of Chicago Social Service Series, 1940. 894 pp.

Abbott, Grace. The Child and the State. Chicago: University of Chicago Social Service Series, I938. Vol. I, 679 pp.; Vol. II, 7or pp.

Blackburn, William J., Jr. The Administration of Criminal Justice in Franklin County, Ohio. Baltimore: The Johns Hopkins Press, 1935. $274 \mathrm{pp}$.

Bonger, William Adrian. Criminality and Economic Conditions.

Boston: Little, Brown \& Co., I9I6. 706 pp.

Bradway, John S., "Children of Divorced Parents," Law and Contemporary Problems. Durham: Duke University School of Law, 1944. Vol. X, No. 5, pp. 697-866.

Bureau of the Census. Fifteenth Census of the United States: 1930:

Metropolitan Districts, Population and Area. Washington: Government Printing Office, 1932. 253 pp.

Bureau of the Census. Governmental Units in the United States

1942. Washington: Government Printing Office, 1944. 67 pp. Bureau of the Census. Governmental Units Overlying City Areas.

Washington: Government Printing Office, 1947.55 pp.

Bureau of the Census. Patients in Hospitals for Mental Disease 1934.

Washington: Government Printing Office, 1936. 45 pp.

Bureau of the Census. Population Characteristics of Metropolitan

Districts. Washington: Government Printing Office, April, I947. $8 \mathrm{pp}$.

Bureau of the Census. "Population Characteristics of the Detroit, Mich., Metropolitan District: April, 1947," Current Population Reports. 1947. Series P-21, No. 19, 5 pp.

Bureau of the Census. Prisoners in State and Federal Prisons and

Reformatories 1939. Washington: Government Printing Office, I94I. $99 \mathrm{pp}$.

Bureau of the Census. Sixteenth Census of the United States: 1940, Population and Housing, Families, General Characteristics; States, Cities of 100,000 or more, and Metropolitan Districts of 200,000 or More. Washington: Government Printing Office, I943. $332 \mathrm{pp}$. 
Burgess, Ernest W. and Locke, Harvey J. The Family. New York: American Book Company, 1945. 800 pp.

Burt, Cyril. The Young Delinquent. Bickley, Kent: University of London Press, Ltd., 4th and rev. ed., 1945. 662 pp.

Burton, Clarence M. and Burton, M. Agnes. History of Wayne County and the City of Detroit, Michigan. Chicago: The S. J. Clarke Publishing Company, 1930. 5 Vols. Vol. I, 796 pp.

California Special Crime Study Commission. Second Progress Report. Sacramento, California: March 7, 1949. 5 pts.

Callender, Clarence N. American Courts; Their Organization and Procedure. New York: McGraw-Hill Book Co., Inc., I927. 284 pp.

Carpenter, William Seal. Problems in Service Levels; the Readjustment of Services and Areas in Local Government. Princeton: Princeton University Press, 1940. 234 pp.

Carr, Lowell Juilliard. Delinquency Control. New York: Harper \& Bros., Ist ed., I94I. 447 pp.

Carr, Lowell Juilliard. "Organization for Delinquency Control," The Annals of the American Academy of Political and Social Science. Philadelphia: 1949, Vol. 26I, pp. 64-76.

Charter of the City of Bloomfield Hills, Michigan. Printed by Authority. Birmingham, Michigan: The Eccentric, Printers, 1932. 32 pp.

Circuit Court of Wayne County, Michigan. Instructions to the Jurors. 25 pp.

Circuit Court of Wayne County, Michigan. Rules for the Circuit Court for the Third Judicial Circuit of Michigan. (Revised to April 1, 1948). 28 pp.

Circuit Court of Wayne County, Michigan. Twenty-fifth Annual

Report of the Probation Department. First report, July I, 1947 to June 30 , I948. I 2 pp.; second report, July I, I948 to June 30 , I949. I2 pp.

City of Highland Park, Michigan. Municipal Court Rules. 1945. $12 \mathrm{pp}$.

Clark, Charles E. and Shulman, Harry. A Study of Law Administration in Connecticut; a Report of an Investigation of the Activities of Certain Trial Courts of the State. New Haven: Yale University Press, 1937. 239 pp. 
Connecticut. Report of the Commission to Study the Integration of the State Judicial System. Hartford: 1944. 5 I pp.

Cooper, Frank E. Pre-trial Procedure in the Wayne County Circuit Court, Detroit, Michigan. Sixth Annual Report of the Judicial Council of Michigan, Ann Arbor: 1936. pp. 61-75.

Cooper, Frank L. and Dawson, John P. The Office of the Friend of the Court in Wayne County, Detroit, Michigan; A Study in Judicial Administration. Fifth Annual Report of the Judicial Council of Michigan, Ann Arbor: 1935. pp. 51-160.

Detroit. Annual Report of the Auditor General of the City of Detroit, Michigan, for the Fiscal Year Ended June 30, 1947. I $27 \mathrm{pp}$.

Detroit Common Pleas Court. Rules of the Common Pleas Court for the City of Detroit. Effective May 15, 1946. Detroit: 1946. $38 \mathrm{pp}$.

Detroit Department of Public Welfare. Monthly Statistics, February, 1948.

Detroit, Michigan. Annual Report of the Psychopathic Clinic of Recorder's Court Detroit, Michigan. 1940. 59 pp.

Detroit Police Department. Annual Report. Detroit: Compiled by Record Bureau, I946. I947. I948.

Detroit Recorder's Court. Jurors' Manual for the Recorder's Court of the City of Detroit. I4 pp.

Drown, Frank S., ed., Thirty-fifth Annual Report of the Municipal Court of Philadelphia. 1948. 357 pp.

Federal Bureau of Investigation, United States Department of Justice. Uniform Crime Reports for the United States and Its Possessions. Washington: Government Printing Office, I947. Vol. XVIII, No. I, 74 pp.

Freeman, Donald. "The Public Defender System," Journal of the American Judicature Society. Ann Arbor: The American Judicature Society, October, 1948. Vol. 32, No. 3, pp. 74-78.

Fuller, Hugh N. Criminal Justice in Virginia. New York: The Century Co. for the Institute in the Social Sciences, University of Virginia, 1931. I95 pp.

Gehlke, C. E. Criminal Actions in the Common Pleas Courts of Ohio. Baltimore: The Johns Hopkins Press, 1936. 326 pp. 
Gillis, Joseph A. "The Conciliation Division of the Common Pleas Court." Reprint of an address delivered to the Detroit Bar Association January 9, 1935.

Gillis, Joseph A. "The Constables and the Conciliation Division," Detroit Bar Quarterly. Detroit: Detroit Bar Association, February, 1937. Vol. V, No. 2 pp. 7-Io.

Gist, Noel P. and Halbert, L. A. Urban Society. New York: Thomas

Y. Crowell Company, 5th ed., 1937. 724 pp.

Glueck, S. Sheldon. Mental Disorder and the Criminal Law; a Study in Medico-sociological Jurisprudence, with an Appendix of State Legislation and Interpretive Decisions. Boston: Little, Brown and Company, 1925. 693 pp.

Glueck, Sheldon and Eleanor. Criminal Careers in Retrospect. New York: The Commonwealth Fund, 1943. 380 pp.

Glueck, Sheldon and Glueck, Eleanor T. Five Hundred Criminal Careers. New York: A. A. Knopf, 1930. 365 pp.

Glueck, Sheldon and Eleanor T. Five Hundred Delinquent Women.

New York: A. A. Knopf, 1934. 539 pp.

Glueck, Sheldon and Eleanor. Juvenile Delinquents Grown Up.

New York: The Commonwealth Fund, 1940. 330 pp.

Glueck, Sheldon and Eleanor. Later Criminal Careers. New York:

The Commonwealth Fund, 1937. 403 pp.

Glueck, Sheldon and Eleanor T. One Thousand Juvenile Delinquents; Their Treatment by Court and Clinic. Cambridge: Harvard University Press, I934. 34I pp.

Glueck, Sheldon and Eleanor, eds. Preventing Crime, A Symposium. New York: McGraw-Hill Book Co., Inc., rst ed., r936. 509 pp.

Haynes, Evan. The Selection and Tenure of Judges. Newark: The National Conference of Judicial Councils, 1944. $308 \mathrm{pp}$.

Healy, William and Healy, Mary Tenney. Pathological Lying, Accusation and Swindling; A Study in Forensic Psychology. Boston: Little, Brown and Company, 1915. $286 \mathrm{pp}$.

Hentig, von Hans. The Criminal and His Victim. New Haven: Yale University Press, 1948. $461 \mathrm{pp}$.

Hunter, Joel D., ed. Survey of Community Services in Wayne County, Michigan. 1948. 
Jayne, Ira W. "The Mouse in the Mountain," The Detroit Lawyer. Detroit: The Detroit Bar Association, December, 1948. Vol. I6, No. I2, pp. 237-240.

Jellinek, E. M. "Recent Trends in Alcoholism and in Alcohol Consumption," Quarterly Journal of Studies On Alcohol. New Haven: June 1947. Vol. 8, No. I, pp. I-42.

Jones, Victor. Metropolitan Government. Chicago: The University of Chicago Press, 1942. 364 pp.

Kimball, Jessica Sinclair. A Manual of Court Function and Procedure for Social Workers. I945. 25 pp.

Lapp, Theodore E., Cooper, Frank E., and Dawson, John P. The Administration of Family Law in Michigan, Seventh Annual Report of the Judicial Council of Michigan. Chicago: Callaghan \& Company. 1937. pp. 57-191.

Lenroot, Katherine F. and Lundberg, Emma O. Illegitimacy as a Child-Welfare Problem. U. S. Children's Bureau Bulletin No. 75, Washington: Government Printing Office, 1921. 408 pp. Lepawsky, Albert. The Judicial System of Metropolitan Chicago. Chicago: The University of Chicago Press, 1932. 265 pp.

Lottier, Stuart. "Distribution of Criminal Offenses in Sectional Regions," Journal of the American Institute of Criminal Law and Criminology. Chicago: Northwestern University Press, MayJune 1938. Vol. XXIX, pp. 329-344.

Lottier, Stuart. "Regions of Criminal Mobility," Journal of the American Institute of Criminal Law and Criminology. Chicago: Northwestern University Press, 1938. Vol. XXVIII, pp. 657673.

Macomb County, Michigan. Official List of County, City, Village and Township Officers. County Clerk. I948.

Maher, John J. Mind Over Motor. Detroit: i 937. I 78 pp.

McKenzie, R. D. The Metropolitan Community. New York: McGraw-Hill Book Company, 1933. 352 pp.

Michael, Jerome and Adler, Mortimer J. Crime Law and Social Science. New York: Harcourt, Brace \& Company, 1933. 440 pp.

Michigan. Juvenile Court Statistics-Semi-Annual Report. Lansing: Compiled by the Juvenile Court Reporting Unit State Department of Social Welfare, November I, 1946. Io pp. 
Michigan Official Directory and Legislative Manual. State of Michigan: Department of State, 1947-1948. 854 pp.

Minnesota, Judicial Council. Report of the Committee on Unification of the Courts to the Judicial Council of Minnesota. St. Paul : West Publishing Co., 1942. 30 pp.

Moley, Raymond and Wallace, Schuyler C., eds. "Administration of Justice," The Annals of the American Academy of Political Science. Philadelphia: May, I933. Vol. 167, 256 pp.

Mumford, Lewis. The Culture of Cities. New York: Harcourt, Brace and Company, 1938. 586 pp.

Murphy, Charles K. The Spirit of the Society of St. Vincent De Paul. Dublin, Ireland: The Society of Saint Vincent De Paul, 2d ed., I944. $213 \mathrm{pp}$.

New York. Fourteenth Annual Report of the Judicial Council of the State of New York. New York: Publishers Printing Co., 1948. $268 \mathrm{pp}$.

Northrop, Everett H. "Small Claims Courts and Conciliation Tribunals: A Bibliography," Law Library Journal. Washington: American Association of Law Libraries, March 1940. Vol. 33, No. 2, pp. 39-50.

Nugent, Rolf. "Devices for Liquidating Small Claims in Detroit," Law and Contemporary Problems. Durham: Duke University Press, April, 1935. Vol. 2, No. 2, pp. 259-268.

Oakland County, Michigan. Official List of County, City, Village and Township Officers. County Clerk. I948.

O'Hagan, Charles. Detroit Recorder's Court. Michigan Historical Records Society. 1942.

Pollock, Herman I. "The Voluntary Defender as Counsel for the Defense," Journal of the American Judicature Society, Ann Arbor: The American Judicature Society, April, 1949. Vol. 32, No. 6, pp. I74-I77.

Porter, Charles O. "Defects in the Administration of Justice in Hamilton County (Cincinnati), Ohio," Journal of the American Judicature Society. Ann Arbor: The American Judicature Society, June, 1948. Vol. 32, No. I, pp. I4-22.

Pound, Roscoe. "The Administration of Justice in the Modern City," Harvard Law Review. Cambridge: February, 1913. Vol. XXVI, No. 4, pp. 302-328. 
Pound, Roscoe. "Causes of Popular Dissatisfaction with the Administration of Justice," Reports of the American Bar Association. Philadelphia: Dando Printing and Publishing Co., 1906. Vol. XXIX, Part I, pp. 395-4I7.

Pound, Roscoe. Organization of Courts. Boston: Little, Brown and Company, I940. $322 \mathrm{pp}$.

Pound, Roscoe and Frankfurter, Felix, eds. Criminal Justice in Cleveland; Reports of the Cleveland Foundation Survey of the Administration of Criminal Justice in Cleveland, Ohio. Cleveland: The Cleveland Foundation, 1922. 729 pp.

Risk, Mary Henderson. "Instalment Sale Contracts in the Detroit Conciliation Court," Law and Contemporary Problems. Durham: Duke University Press, April, 1935. Vol, 2, No. 2, pp. 269-284.

Schramm, Gustav L. Piedpoudre Courts; a Study of the Small Claim Litigant in the Pittsburgh District. Pittsburgh: The Legal Aid Society, 1928. $219 \mathrm{pp}$.

"Second Draft of a Model Act to Establish a Court for a Metropolitan District," American Judicature Society to Promote the Efficient Administration of Justice. Chicago: C. H. Morgan Co., January, Igı6. Bulletin IV-B (Bulletin IV rev.), 94 pp. Sellin, Thorsten, ed. "Juvenile Delinquency," The Annals of the American Academy of Political and Social Science. Philadelphia: January, 1949. Vol. 26I, 233 pp.

Selling, Lowell S. "The Psychopathic Clinic in a Criminal Court, Its Uses and Possibilities-A Reprise." Journal of the American Judicature Society. Ann Arbor: The American Judicature Society, April 1945. Vol. 28, No. 6, pp. I69-I73.

Shartel, Burke. "Federal Judges-Appointment, Supervision and Removal-Some Possibilities Under the Constitution," Michigan Law Review. Ann Arbor: University of Michigan Law School, March, April, May 1930. Vol. XXVIII, pp. 485-529, 723-738, 870-909.

Shartel, Burke. "Retirement and Removal of Judges," Journal of the American Judicature Society. Ann Arbor: The American Judicature Society, December, I936. Vol. 20, No. 4, pp. I33-153. Simes, Lewis M. and Basye, Paul E. Problems in Probate Law: Model Probate Code. Ann Arbor: The University of Michigan Press, 1946. 782 pp. 
Skillman, W. McKay. "Slow Justice'-an Answer," Michigan State Bar Journal. Hastings: State Bar of Michigan, August, I 948. Vol. XXVII, No. 8, pp. 33-37.

Smith, Reginald Heber. Justice and the Poor; A Study of the Present Denial of Justice to the Poor and of the Agencies Making More Equal Their Position Before the Law, With Particular Reference to Legal Aid Work in the United States. New York City: The Carnegie Foundation for the Advancement of Teaching, Bulletin No. 13, 2d ed., 1919. 27 I pp.

Smith, Sweetman G. Practice and Procedure in the Common Pleas Court of Detroit, Embracing Local, Special and General Acts and Rules Annotated. Chicago: Callaghan \& Co., 1938. I37 pp. Snively, John R. "The Right of an Accused to the Assistance of Counsel," Journal of the American Judicature Society. Ann Arbor: The American Judicature Society, December, I948. Vol. 32, No. 4, pp. III-II4.

Society of St. Vincent de Paul of Detroit. 6oth Annual Report for the Year 1947.

Statutes of the State of Michigan and Rules for the Recorder's Court of the City of Detroit. 1938. 136 pp.

Stermer, James E. and Rosemont, Harold N. Manual for Juvenile Court Officers of the State of Michigan. Lansing: W. P. A. Emergency Recreation Division, 1936. II5 pp.

Stewart, William Scott. "The Public Defender System is Unsound in Principle," Journal of the American Judicature Society. Ann Arbor: The American Judicature Society, December, 1948, Vol. 32, No. 4, pp. II 5-II8.

Straus, Robert. "Alcohol and the Homeless Man," Quarterly Journal of Studies on Alcohol. New Haven: Journal of Studies on Alcohol, Inc., December, I946. Vol. VII, No. 3, pp. 360-404. Studenski, Paul. The Government of Metropolitan Areas in the United States. New York: National Municipal League, 1930. $403 \mathrm{pp}$.

Sunderland, Edson R. The Efficiency of Justices' Courts in Michigan. Fourth Annual Report of the Judicial Council of Michigan. Ann Arbor: 1934. pp. I69-I 22.

Sunderland, Edson R. Judicial Administration, its Scope and Methods. Chicago: Callaghan \& Co., 1937. 1395 pp. 
Sunderland, Edson R. A Study of Justices of the Peace and Other Minor Courts; Requisites for an Adequate State-wide Minor Court System. Fifteenth Annual Report of the Judicial Council of Michigan. Lansing: I945. pp. 53-I I8.

Sunderland, Edson R. "Subject-Matter Jurisdiction of Minor Courts," Journal of the American Judicature Society. Ann Arbor: American Judicature Society, April, 1946. Vol. 29, No. 6, pp. 175-185.

Sunderland, Edson R. "Territorial Jurisdiction of Minor Courts," Journal of the American Judicature Society, Ann Arbor: American Judicature Society, February, 1946. Vol. 29, No. 5, pp. I 47-I 55 .

Sunderland, Edson R. and Campbell, Morse D. Michigan Probate Procedure for the Commitment of Insane, Feeble-minded and Epileptic Persons to Institutions for Their Care, and the Release of Such Persons. Thirteenth Annual Report of the Judicial Council of Michigan. Lansing: 1943. pp. 57-198.

Tappan, Paul W. Delinquent Girls in Court. A Study of the Wayward Minor Court of New York. New York: Columbia University Press, 1947. 265 pp.

Thompson, Guy A., chairman. The Missouri Crime Survey. New York: The Macmillan Company, 1926. $587 \mathrm{pp}$.

Tietze, Christopher, Lemkau, Paul, and Cooper, Marcia. "Personality Disorder and Spatial Mobility," The American Journal of Sociology. Chicago: The University of Chicago Press, July, 1942. Vol. XLVIII, No. 1, pp. 29-39.

United States National Commission on Law Observance and Enforcement, Report on Prosecution. Washington: Government Printing Office, I931. Vol. 4, 337 pp.

Vanderbilt, Arthur T. Minimum Standards of Judicial Administration. New York: Published by the Law Center of New York University for the National Conference of Judicial Councils, 1949. $752 \mathrm{pp}$.

Waite, John Barker. The Prevention of Repeated Crime. Ann Arbor: University of Michigan Press, 1943. $221 \mathrm{pp.}$ 
Waite, John B. "'Slow Justice' in Michigan," Michigan State Bar Journal. Hastings: State Bar of Michigan, July, 1948. Vol. XXVII, No. 7, pp. 17-20.

Warner, Florence M. Juvenile Detention in the United States; Report of a Field Survey of the National Probation Association. Chicago: The University of Chicago Press, 1933. 227 pp.

Warner, Sam Bass. Crime and Criminal Statistics in Boston. Cambridge: Harvard University Press, 1934. I50 pp.

Warner, Sam Bass and Cabot, Henry B. Judges and Law Reform. Cambridge: Harvard University Press, 1936. 246 pp.

Watts, Reginald E. "The Influence of Population Density on Crime," The Journal of the American Statistical Association. Concord: Rumford Press, March, I93I. Vol. XXVI, New Series, No. I 73, pp. I I-20.

Wayne County, Michigan. Annual Financial Report. Detroit: 19461947. $78 \mathrm{pp}$.

Wayne County, Michigan. Annual Report of the Friend of the Court of the Circuit Court. 1947. 19 pp.; 1948. 19 pp.

Wayne County, Michigan. Official List of County, City, Village and Township Officers. Compiled by E. M. Branigin, County Clerk. 1948. 67 pp.

Whalen, Cecile M. Tenure, Training and Compensation of Detroit Social Workers. Detroit: Detroit Bureau of Governmental Research, Inc., 1938. $68 \mathrm{pp}$.

White, R. Clyde. "The Relation of Felonies to Environmental Factors in Indianapolis," Social Forces. Chapel Hill: University of North Carolina Press, May, 1932. Vol. X, No. 4, pp. 498-509. Whitehead, John L. Methods of Selection of Trial Jurors. Unpublished. Detroit, 1939.

Wigmore, John H., ed. The Illinois Crime Survey. Compiled by the Illinois Association for Criminal Justice. Chicago : Blakely Printing Co., 1929. 1108 pp.

Willoughby, William Franklin. Principles of Judicial Administration. Washington: The Brookings Institution, 1929. $662 \mathrm{pp}$.

Woolston, Howard. Metropolis; A Study of Urban Communities. New York: D. Appleton-Century Co., Inc., 1938. 325 pp.

Worthington, George E. and Topping, Ruth. Specialized Courts Dealing with Sex Delinquency; A Study of the Procedure in Chicago, Boston, Philadelphia and New York. New York: F. H. Hitchcock, 1925. 460 pp. 
Young, Pauline V. Social Treatment in Probation and Delinquency; Treatise and Casebook for Court Workers, Probation Officers and Other Child Welfare Workers. New York: McGraw-Hill Book Company, Inc., Ist ed., I937. 646 pp.

Zink, Harold. Government of Cities in the United States. New York: Macmillan Co., rev. ed. 1948. 637 pp. 


\section{Index}

Abandonment, 23I.

Administrative agencies within courts, I49-186.

cases disposed of by, 215 .

Friend of the Court, I73-180. mental division, probate court,

186-193.

used for investigation and supervision, I5-16, 268.

Administrators, public, I30-I3I. Adoption, 42, 185, 232, 236, 249. Age of cases, 206-218.

Aid

to dependent children, 254, $257,262$.

to dependent parents, 258-259.

Alcoholics Anonymous, 164, 253. Alcoholism, chronic. See Chronic alcoholism.

Alimony. See also Friend of the Court.

automatic checkup, I 78-1 79 .

compulsory payment to Friend of the Court, I78-I79.

American Bar Association, Section of Judicial Administration, Committee on Metropolitan Trial Courts, VII, Appeal XI, XIV-XVI, 3.

from circuit court commissioners judgment, 34 . trials de novo, 222.

Arraignment

by circuit court, I 99.

by recorder's court

on information, 83 .

on warrant, I99.

Arrearage. See Alimony.

Assignment clerk, circuit court, 197-198.

attendance of judges, 93 .
Assignment of cases, circuit court, 194-199. See also Docket. Attorneys, in courts, I08-II7. Auditor general, Detroit, 247.

Bail bond bureau, recorder's court, I 44 .

Bail cases, age of, 208.

Bailiffs, I3I-135.

Bastardy, 33, 232, 238, 263.

Births, illegitimate, in Detroit and Wayne County, 28.

Board of Education, Detroit, psychopathic clinic, $25 \mathrm{I}$.

Boston, juvenile delinquents, 30 . Boys' Republic, 255.

Boys' section, juvenile court, I66I 68.

Boystown, 255.

"Branding law," 38.

Burt's juvenile delinquency study, 29-30.

Calendar, circuit court, 195-196. "No progress," 196. trial, 195-196.

Calls, circuit court, 197-198. See also Dockets; Calendar.

Case load

child caring agencies, 28 .

chronic alcoholics, 24-25.

clinic for child study, I 85-186. family relief in Detroit, 257.

Friend of the Court, 175, I76$177,179$.

heavy, I0-16, 268. See also Cases.

machinery for disposition of, 194-218.

per judge, 96-Ioo.

probate court, 204 .

probation department, circuit court, 156. 
Case load (continued)

probation department, juvenile court, I68-I69, I 70 .

probation department, recorder's court, 164-165.

domestic relations section, I 59, 160 .

men's section, 163,164 .

pre-court adjustment section, 158 .

women's section, 162 .

psychopathic clinic, recorder's court, 183 .

Society for St. Vincent de Paul, 255.

Cases

transfer and exchange of, 238.

$$
\begin{aligned}
& \text { age of, } 205-2 \text { I } 8 \text {. } \\
& \text { circuit court, 205-207. } \\
& \text { recorder's court, } 207-2 \text { I4. } \\
& \text { bail, 207-208. } \\
& \text { jail, 208-2II. }
\end{aligned}
$$

assignment of, circuit court, 198.

characteristic, of metropolitan areas, $16-30$.

criminal, 20-23.

domestic relations, 25-30.

habitual drunkenness, 23-25. mental cases, $16-18$.

traffic cases, I 8-20.

disposed of

by court administrative agencies, 215.

by police, $214-215$.

summarily, 2 I 5-216.

without trial, 214.

without use of legal safeguards, 216-2I7.

jury, circuit court, 128, 129. nonjury, circuit court, I 29. timely disposition of, 214-218.

Central registration bureau, 264267.

Centrifugal drift of metropolitan population, 20, 268.

Chancery

age of cases, circuit court 205 . jurisdiction, circuit court, 33 . masters in, 33-35.

Child-caring agencies, load, 28.

Child placement

Children's Aid Society, 254255.

Society for St. Vincent de Paul, 255.

State Department of Public Welfare, 254.

welfare agencies concerned with, 254-256.

Child study clinic, juvenile court, I83-186, 236.

\section{Children}

abandonment, overlapping jurisdiction, 23I.

adoption, 42 .

afflicted, 4I-42.

board of education, mental cases, $25 \mathrm{I}$.

clinic for child study, 183-184. crippled, 4I-42. cruelty to, 231 .

delinquent, 39-40.

dependent and neglected, 3739.

Detention Home, I71-172.

Friend of the Court, 173-180. illegitimate

affidavit of acknowledgment, 36.

civil acknowledgment, 33 .

Friend of the Court, I77I 78 .

in care of Wayne County, 28. juvenile court jurisdiction, 3744.

of divorced parents, 40 .

offenses against, 28-29.

placement agencies, 254-256.

probation department, juvenile

court, I65-170.

traffic offenders, 42.

wayward minors, 40-4I.

Children's Aid Society, 254-255. 
Children's bureau, State Department of Public Welfare, 254.

Chronic alcoholism

case load

characteristic of metropoli$\tan$ area, 23-25.

in Detroit, 24-25.

in probate court, $25,192$.

in recorder's court, 24-25, $163-164$.

in traffic and ordinance court, 24-25.

"golden rule," 215.

overlapping jurisdiction, 223225.

rate of, in Detroit, 24-25.

Circuit Court of Wayne County. See also Circuit courts. assigned counsel, I08-I I3. cases disposed of prior to, or without, trial with full legal safeguards, 2I4-2 I8. co-operation with welfare agencies, 260-264.

counsel, I08-II3, II7. court records, $137-140$. criminal case load, 23. divorce case load, 27 . docket, r 94-199.

Friend of the Court, I73-I8o. as referee, IOI. office of, I 73-18o.

judges age of, 62 .

as "one-man grand jury," 80 .

case load per judge, 96-97. compensation of, 68-69. experience of, $56-58$. legal education of, 56-58. organization of judicial personnel, 75-8o.

presiding, $75-77$. presiding miscellaneous, 798 o.

pre-trial, $77-80$.

judgments, I29, I30. judicial committees, 8 o.

judicial services rendered, 9394.

jurisdiction of, $3 \mathrm{I}-35$.

jury

cases (1947), 124, I29. selection of, I I9-1 20.

use of, $123-126$.

mental problems, I81-192.

personnel for court records, $137-140$.

pre-trial hearing, 77-79, 273-

274.

in relation to docket, $194-$ I95.

probation department, I52I 56 .

prosecutors, I08-II3.

"quick justice," I I2-I I 3.

Circuit Court Commissioners of Wayne County

as quasi-judicial personnel, IOO-IOI.

jurisdiction of, 33-35.

use of juries, I27.

Circuit courts. See also Circuit Court of Wayne County.

in Detroit metropolitan area, 6 . jurisdiction of, 3I-35. jury selection methods, I 19129.

judges

age of, 62 .

case load per judge, 96-97. compensation of, 68-69. methods of selecting of, 64 . organization in multi-judge courts, $75-80$.

qualifications of, 56-57. services rendered, 93-94. specialized and administrative, use of, 9I-92.

Cities, in Detroit metropolitan area, 5 .

City courts, XII. See also Recorder's court; Court of common pleas. 
City courts (continued)

in metropolitan district outside Detroit

juries, $50-55$.

selection of, $\mathbf{I} 23$.

probation in, I70-I $7 \mathrm{I}$.

City justice courts. See also Court of common pleas.

in Detroit metropolitan district, 5 .

in Detroit metropolitan district outside Detroit, 52.

City justices in Detroit metropolitan district outside Detroit

compensation of, 52 .

jurisdiction of, 52 .

qualifications of, 62 .

selection of, 66 . size of staff, I 4 .

Civil acknowledgment proceedings, 33 .

Civil cases

\section{jurisdiction of}

court of common pleas, 50 .

minor courts in Detroit metropolitan district outside Detroit, 50-55. recorder's court, 46 .

Civil jurisdiction

of circuit court, 3I-33.

of courts in Detroit metropoli$\tan$ district outside Detroit, 54.

Civil service

circuit court employees, 137 . court of common pleas employees, I 46 . juvenile court employees, I 42 . probate court employees, I 40. probation officers, I $5 \mathrm{I}-152$, I 57, 165-166.

traffic and ordinance court employees, I 45 .

Civil Service Commission of Wayne County, 137.

Clerical personnel, I35-149. See also Personnel, clerical.
Clinic for child study, juvenile court, I 83-1 84 .

Collection

of family support by Friend of the Court, I73-180.

of family support by pre-court adjustment section, recorder's court, I 57-I 59 .

of family support, fines, etc. by circuit court probation department, I 53-I 55.

Common pleas court. See Court of Common Pleas of the City of Detroit.

Compensation, of judges, 68-72. Complaint and enforcement department, I78-179.

Conciliation docket, circuit court, 197.

Conclusions, 268-27o.

Condemnation cases, 46.

Conflicting jurisdiction, 2 I 9-232.

Consolidation of courts in Detroit metropolitan area outside Detroit, 54.

Cook County, Illinois

large court staffs, I4-I 5 .

metropolitan case load, 13 .

Constables, court of common pleas, $13 \mathrm{I}$.

Co-operation, among courts in Detroit, 233-248.

Counsel

journal entries in Detroit courts, 147 .

use of, in Detroit metropolitan area, I08-II7.

for defense, IO8-I 14, II 7 .

assigned, IO9-I II.

Legal Aid Bureau of Detroit, II 7 .

Counties, in Detroit metropoli$\tan$ district, 5 .

County

agent, 249.

auditor

aid to dependent parents division, 258.

at recorder's court, 145 . 
County (continued)

clerk, circuit court, 137. prosecutor

felony cases, I08-iog.

traffic and ordinance cases,

$$
\text { I } 13 \text {-I I } 4 \text {. }
$$

Court agencies, dealing with men-

tal problems, I8I-192.

Court costs, collection of, I54I 55 .

Court of Common Pleas of the

City of Detroit

assignment clerk, 87-88.

bailiffs, I 3 I-I 35 .

cases disposed of prior to, or without, trial with full legal safeguards, 2I4-2I8.

constitutionality, 48 .

counsel in, 116 .

docket, 205 .

judges

age of, 63 .

attendance, 95-96.

case load, 97-98.

compensation, 70-71.

conciliation judge, 88-90.

hours of service, $95-96$.

presiding, 87-88.

qualifications, $6 \mathrm{I}$.

jurisdiction of, 48--50,

jury

selection of, I2I.

use of, 127 .

official court records, personnel, I 46-1 47.

process service, I3I-I35.

Courts. See also under specific court.

extent of treatment in survey, 5, 90-9I.

in Detroit, co-operation, 233248.

in Detroit metropolitan district, 6.

attorneys and juries, 108I 29.

clerical and administrative personnel, 130-193. judicial personnel, 50-107. in Detroit metropolitan district outside Detroit

civil jurisdiction, 54 .

consolidation, 54 . judges

compensation of, 62 .

qualifications of, 62 .

selection of, 66-68.

multi-judge. See Multi-judge courts.

overlap with welfare agencies, $27 \mathrm{I}$.

records, 137-140.

reporters, 136 .

reports, I47-I 50.

staffs. See Personnel.

Creditors' bill, 34 .

Crime rate, 21 .

Criminal cases

age, 206-2i3.

as characteristic of metropolitan courts, 20-23.

case load, 268.

comparative figures, I2, 23.

defense counsel, IO8-II3, I I4. disposed of prior to, or without, trial with full legal safeguards, 2I 4-218.

juvenile court proceedings, II 8 . murder, I I9.

prosecutors, IO8-II3, II4.

Criminal nonsupport, $23 \mathrm{I}$.

Criminal offenses, jurisdiction of circuit court, 35 .

court of common pleas, 50 . minor courts in Detroit metropolitan district outside Detroit, 50-55.

recorder's court, 45-46.

related to population density, 29-30.

traffic and ordinance court, 47. welfare agencies, concerned with, $254^{-256}$.

Criminal Sexual Psychopathic Act, I I8-II9. 
Crippled children, 4I-42.

Cruelty to children, 231 .

Curfew ordinance, 230.

Custody, parental, 169. See also

Friend of the Court.

\section{Dearborn}

court, 8 .

jurisdiction, 5I, 55 .

personnel, I4.

Decedents' estates, 36 .

Default, cases disposed of by, at court of common pleas, i i6, 133.

Defective jurisdiction, Detroit courts, 219-232.

Defense counsel, IO8-1I7.

assigned, IO9-I I 2 .

in felony cases, III-II3.

in misdemeanor cases, ro8.

"quick justice," I I 2-II 3 .

Delinquent children

contributing to delinquency, 231.

in care of institutions, 28 . jurisdiction of juvenile court, 39-40.

Density of population, metropolitan characteristic, IO- 12,20 , 268.

Dependent and neglected children

in care of institutions, 28 .

jurisdiction of juvenile court, 37-39.

section of probation department, juvenile court, I68I69.

Dependent parents, aid to, 258 259.

Destitution

and domestic relations cases, 30.

and rate of crime, 21 .

\section{Detention}

by juvenile court, 43 .

of alleged mentally afflicted, I 86. of wayward minors with adult offenders, 229.

Detention home of juvenile court, I 70-I 7 I.

case load, 172 .

Detroit, city of. See also under specific courts, agencies, or departments.

courts in, 6 .

population density, IO-I I.

relationships among courts, law enforcement and welfare agencies, $219-267$.

Detroit Council of Social Agencies, 250, 257 .

Detroit Department of Public Welfare, 192, 250, 260.

Detroit metropolitan district, 4 . courts in, 6 .

governmental units in, 4-8. jurisdiction of courts in, $3 \mathrm{I}-55$. map of, 6 .

townships in, 5 .

villages in, 5 .

Detroit Receiving Hospital, mental cases, I 88, 25 I.

Discovery proceedings, 34 .

Divorce

case load, circuit court, 27.

rate in cities, 26-27.

Divorced parents, children of, 40 .

Docket, machinery for handling, 194-21 8, 268.

circuit court, 194-199.

special, I96-I97.

recorder's court, I99-203.

clerk, 200-203.

Domestic relations. See also Delinquent children; Dependent and neglected children ; Family welfare ; Family support; Friend of the Court; Juvenile court.

cases

characteristic of metropolitan court case load, 2530. 
Domestic relations (continued) cases (continued)

predominance in circuit court, 33 .

related to destitution, 30 . jurisdiction, overlapping, defective and conflicting, 23I232, 268-27o.

Domestic Relations Court of Wayne County

history of, 25-26. unconstitutional, 26 .

Domestic relations section, probation department, recorder's court, I 59-16o.

Drug addicts, 36 .

Drunkenness, habitual. See also Chronic alcoholism.

as characteristic of metropolitan court case load, 23-25. jurisdiction of probate court, 36.

Duplication between courts and social agencies, $266 \mathrm{ff}$.

Duration of cases, 206-218.

"Early Sessions," misdemeanor division, recorder's court, $85-87$.

Enforcement department, Friend of the Court, I78-179.

Epileptics, 36.

Escheated estates, public administrator in, $130-131$.

Examinations, preliminary, recorder's court, I99.

Exchange of personnel, facilities, etc. among Detroit courts, 233-238.

Experience, of judges, 56-62.

Facilities, exchange of, 236-238. Family. See also Domestic relations.

case work

by probation officers, $\mathrm{I} 55$. court administrative agencies, I49-I 93, 24I-245. overlap between court and social agencies, 267 .

welfare agencies concerned with, 255-256.

defective relationships, 25-30. offenses against, 28-29.

problems, related to juvenile delinquency, 29.

supervision, duplication of, 244-245.

support

collection by

circuit court, probation department, I53-I 54 .

domestic relations section, recorder's court, I 59-I60.

Friend of the Court, I79. See also I73-I80.

pre-court adjustment section, recorder's court, I $56-165$.

Friend of the Court, 24I. inadequate co-operation

between courts, 24I-244. between courts and welfare agencies, 257.

overlapping jurisdiction, $24 \mathrm{I}-244$.

welfare agencies concerned with, 257 .

Family court of Wayne County.

See Domestic Relations

Court of Wayne County.

Feeble-minded children, in care, 28.

Felonies

case load in Detroit, 23. recorder's court machinery for handling docket, 200-203.

Felony division, recorder's court. See also Recorder's Court for the City of Detroit. juries, use of, 126.

Financial support of courts, effect of diversity, 246-248, 270. 
Flint Act city courts judges compensation, $7 \mathbf{I}$. qualifications, 62. selection, 66.

jurisdiction, 50-5I.

Friend of the Court of the Circuit Court of Wayne County, I73-I80.

cashier's department, I79.

disposition of cases prior to trial, 215 .

quasi-judicial functions, IOI. use of, 179-18o.

Garden City, justice's criminal case load, I 2.

Girls' section, probation department, juvenile court, 168 .

Glueck, Boston juvenile delinquency study, 30 .

"Golden Rule." See Police.

Governmental units

in Detroit metropolitan district, 4-8.

multiple, 8-Io, 268.

Grand jury. See "One-man grand jury."

Guardianship

Friend of the Court, 177 .

jurisdiction of probate court, 36.

Habitual drunkenness. See

Drunkenness, habitual.

High misdemeanors

jurisdiction of circuit court, 35 . jurisdiction of recorder's court, 45-46.

Highland Park, city of court, 8.

maximum jurisdiction of, $5 \mathrm{I}$, 55.

personnel, I4.

Home rule charters, XII courts, 6-7.

Home rule city courts

in Detroit metropolitan district, $5 \mathrm{I}-52$. qualifications of judges, 62 .

selection of judges, 66 .

size of staffs, 14 .

Hours of service of judges, in

Detroit, 93-97.

Illegitimacy

in Wayne County and Detroit, 28.

metropolitan rate, 28 .

Illegitimate births. See Births, illegitimate.

Illegitimate children. See Children, illegitimate.

Infants. See Children.

Investigation

department of, Friend of the Court, I 73-174.

use of court administrative agencies for, I 5-I6.

Jail cases, age of, 206-208.

Jayne, Ira W.

chairman, American Bar Association Committee on Judicial Administration in Metropolitan Trial Courts, VII, XI, XIII, XIV-XVI. Council, Section of Judicial Administration of the American Bar Association, XVI. foreword by, VII-X.

Journal entries

circuit court, I38.

comment on, I47.

court of common pleas, 146 .

juvenile court, I42.

probate court ("endorsement system"), I40-I4I.

Judge

presiding, 72-93. See also Presiding judge.

use of in Detroit courts, 9I93.

specialized. See Specialized judges. 
Judges. See also Judicial personnel; Justices; Personnel. age of, 63 .

compensation of, 68-72.

election of, nonpartisan ballot, 63-68.

experience of, 56-62.

in Detroit metropolitan area. case load per judge, 96-100. hours of service, 93-97. services rendered, 93-97.

legal education of

circuit court, 57 .

court of common pleas, $6 \mathrm{r}$.

probate and juvenile court, 58.

recorder's court, 59 .

traffic and ordinance court, 60.

methods of selecting of, $63-67$. organization in multi-judge courts, 74-93.

qualifications of, 56-62. retirement of, 63 . rotation of, recorder's court, $82-87,212$.

Judgments, jury and nonjury cases, circuit court, 129-130.

Judicial administration

American Bar Association, Section of, VII, XI, XIVXVI, 3 .

in Metropolitan Trial Courts, Committee on, VII, XI, $X I V-X V, 3$.

organization in multi-judge courts, 72-93.

Judicial committees, 8o, 86 .

Judicial Council of Michigan, XII, $147-148$.

periodical reports, I47-150.

studies on

mental cases, procedures in

I9I, 192.

pre-trial hearing, I94-195.

Judicial personnel in the Detroit metropolitan district, 56-
107, 275-28I. See also Judges.

exchange of, 234-235.

total, 106-107.

Judicial specialization, I4-I 5 .

Juries

extent of use of, I23-129, 269270.

right to trial by, I 8 -I I9.

selection of, II9-I23.

trial by, in Detroit metropolitan district, II 8-I29.

Jurisdiction

circuit courts, $3 \mathrm{I}-35$.

appellate, 35 .

court of common pleas, 48-50.

juvenile courts, $37-44$.

minor courts, 50 .

tendency towards enlargement, 55 .

probate courts, 36-37.

recorder's court, $44-46$.

traffic and ordinance court, $46-$ 47.

waiver of, 226-227.

Jurisdiction of courts in Detroit metropolitan district, 3I-55. overlapping, defective, conflicting, 219-232.

Jury cases, circuit court, I28,

129.

Jury commissioners

recorder's court, $12 \mathrm{I}$.

use of, by traffic and ordinance court, 122.

Wayne County, I I9-120.

Justice courts

in Detroit metropolitan district, 5 .

jurisdiction of, $50-55$.

outside Detroit, probation in, I70-I 71 .

Justices of the peace in Detroit metropolitan district, jurisdiction of, 48-50, 52-55. 
Juvenile court. See also Juvenile Court of Wayne County; Probate Court of Wayne County; Probate court.

"Branding law," 38.

informal notice of proceedings, 102-105, 166.

jurisdiction in Detroit metropolitan district, 37-44.

"Protected record," 38-39, 238-240.

Juvenile Court of Wayne County cases disposed of prior to, or without, trial with full legal safeguards, 214-21 8 .

clinic for child study, 183-184. counsel in, I I 5-1 6 .

Detention Home, I 70-I7I. docket, 204.

judges

compensation, 69 .

judicial experience, 58-59.

legal education, 58 .

organization of, 82 .

specialized, 88-90.

jurisdiction of, $37-44$. jury

over adults, $42-43$.

selection of, I2I.

use of, 127 .

personnel, I 4 I-I 42, 277-278.

referees, I02-IO5.

Juvenile deliquency, related to family problems, 29 .

Juvenile division, police department, 214, 240, 253, 256 .

Juvenile witnesses, detention of,

I72.

Landlord-tenant cases

case load, roo.

overlapping jurisdiction, 222.

Law cases, age of, circuit court, 205.

Lawyers. See Counsel ; Attorneys.

Legal Aid Bureau of Detroit, I 7 .

Legal education, of judges, 5662.
Macomb County compensation of judges, 68-69. in Detroit metropolitan district, 5 . circuit court, I4. circuit court commissioners, 34. city courts, jurisdiction, 54 .

Marriages duration of, 26 . secret, 36 . validity doubtful, 33 .

Medicolegal problems

Criminal Sexual Psychopath Act, II8-II9.

metropolitan characteristic, 268. See also Child study clinic; Mental cases; Psychopathic clinic.

Men's section, probation department, recorder's court, I63164.

Mental cases

as characteristic of metropolitan courts, I6-I8, 268.

departments of social welfare, county and city, I88, 250$25 \mathrm{I}$.

feeble-minded children, in care, 28.

jurisdiction in, 120 .

overlapping, conflicting, defective, 223.

welfare agencies concerned with, $250-25 \mathrm{I}$.

Mental division, probate court, I4I, I86-I93, 216.

case load, I7-18.

child study clinic, 186.

Mental hygiene clinic, Wayne County, I9I.

Mental problems

clinic for child study, juvenile court, I $83-184$.

court agencies dealing with, I 8 I-I 92.

mental division, probate court, I 86-192, 282-286. 
Mental problems (continued) psychopathic clinic, recorder's court, 18 I-I 83 .

Mentally afflicted detention of, 186. jurisdiction of probate court, 36.

Metropolitan areas characteristics of, 8-30. courts, VII-IX, XI, 3. definition of, 4 . social problems of, XI.

Metropolitan courts administrative agencies, for investigation and supervision, I 5-16.

cases

disposition of without, or prior to, trial with full legal safeguards, 206-218. load, Io-16. special types, 16-30.

dockets, I94-2I5.

judicial specialization, I4-I5. juries, $\mathrm{I} 27-\mathrm{r} 29$.

jurisdiction of minor courts, 55 . multi-judge, $9 \mathrm{I}-93$.

problems of, $268-270$. staffs, I3-I 4 .

Michigan Corrections Commission, 228.

Minor courts in Detroit metropolitan district. See City justices; Courts; Flint Act city courts; Home rule city courts; Township justices.

Minors. See also Children. Jurisdiction, 226-232.

Misdemeanor complaint bureau, Detroit Police Department, 214.

Misdemeanor division, recorder's court. See also Recorder's Court of the City of Detroit. defense counsel, ro8, iro. juries, 126. prosecutor, 108. records, 144.
Misdemeanors

appeal from recorder's court judgments, 35 .

cases

age of, I99-200.

docket, I 99-200.

use of probation, $16 \mathrm{I}, \mathrm{I} 65$, 217.

Mobility

characteristic of metropolitan area, $17,268$.

related to domestic relations cases, crime, 29-30.

Multi-judge courts characteristic of metropolitan area, 9I-93.

effect on election, 67-68.

in Detroit metropolitan district, 74 .

organization, 74-93.

use of specialized and administrative judges, 9I-93.

metropolitan court problem, 269.

Murder, requirement of sanity commission, II9.

Neglected children. See also Dependent and neglected children.

cases in care, 28 .

juvenile court jurisdiction, 3739.

overlapping jurisdiction, $23 \mathrm{I}$.

No progress calendar, circuit court, I96.

Nonpartisan ballot, election of judges by, 63-68.

\section{Oakland County}

compensation of judges, 68-69. in Detroit metropolitan district, 5 . circuit court, I 4 . circuit court commissioners, 34. city courts, jurisdiction, 54 . 
Old age assistance, aid to dependent parents, 258 .

"One-man grand jury" circuit court, 80 . recorder's court, 86 .

Ordinances. See also Traffic and Ordinance Court of the City of Detroit. jurisdiction over, 47 .

Outlying courts in Detroit metropolitan district. See also Courts.

treatment in survey, 5 . use of probation in, 17 O.

Overlap between courts and welfare agencies, 271.

Overlapping jurisdiction in city of Detroit, 219-232. metropolitan court problem, 268-269.

Partial payment orders, common pleas court, 87-9o.

Paternity out of wedlock, overlapping jurisdiction, 23I232.

Periodical reports, court, I47I 50 .

Person, jurisdiction over, overlapping, 219-232.

Personnel. See also Personnel in courts in Detroit metropolitan district ; and under functional headings.

judicial specialization, 14-15. staffs, 13-14, 192-193, 268, 275-28I.

use of administrative agencies, I 5-I6, I 49-I93, 268-269.

Personnel in courts in Detroit metropolitan district, 275281. See also Personnel; under specific functional headings.

administrative agencies, I49I 93.

attorneys, I08-II7.

bailiffs, I3I-I 35 . clerical, I35-1 49 .

in charge of official records, 137-I 47 .

exchange of, 233-235.

judicial

legal education and judicial experience, 56-62.

juries, II 8-I 29 .

quasi-judicial, I00-ıo6.

total, 192-193.

Physicians, in mental cases, 186 I 92, 282-286.

Placement agencies, for children, $254-256$.

Police department, city of Detroit

boys known to, 28 .

cases

disposed of without court action, $214-215,225$.

load, juvenile boys, 168 .

criminal offenses, by precinct, 22.

family and children, offenses against, 28-29.

"Golden Rule" case load, 24, 215.

intoxicated persons known to, 24.

juvenile court contacts, record of, 38 .

juvenile division, 2 I4.

precincts, $\mathrm{I}, 8, \mathrm{I} 3$.

characteristics of, 22.

traffic violations known to, 20.

Violations Bureau, 145.

Population characteristics of a metropolitan area

centrifugal drift, 20 .

density, IO-I 2, 20.

effect on courts, $268 \mathrm{ff}$. mobility, $\mathrm{I} 7-2 \mathrm{O}$.

single men, predominance of, $2 \mathrm{I}$. Pre-court, disposition of cases, 214-2 I 8 .

Pre-court adjustment section, probation department, recorder's court, 157-159. 
Pre-sentence investigation circuit court, probation department, I 52-153.

recorder's court, probation department, I59, I6I-I62, I63-I 65 .

Presiding judge, $75-77,8 \mathrm{r}-82$, $82-84,9 \mathrm{I}-93$.

at circuit court

authority over circuit court commissioners, 34 .

duties of, 75-77.

pre-trial hearing, report on, I95.

at court of common pleas, 8788.

pro tem, 88 .

at recorder's court

duties of, $82-87$.

handling of docket, 200203.

metropolitan court characteristic, 269.

Presiding miscellaneous judge, Pre-trial circuit court, 79-80.

conference, circuit court, 194I 95.

docket, circuit court, 196-197. hearing

circuit court, 78-79, 273274.

in relation to docket, 194I95.

judges, circuit court, 77-79.

Probate court. See also Juvenile

court; Probate Court of Wayne County.

adoption, jurisdiction over, 42 . judges

age of, 63 .

case load per, 97-98.

compensation of, 69 .

organization in multi-judge courts, $80-82$.

selection of, 64 .

specialized administrative, use of, in Detroit, 9I-93.
Probate Court of Wayne County. See also Probate court; Juvenile Court of Wayne County.

aid to dependent parents, 258 259.

cases

disposed of prior to, or without, trial with full legal safeguards, 2I4-2I8.

mental, I7-18.

counsel in, II4-I 5 .

docket, 204.

judges

case load per, 97-98.

compensation of, 69 .

judicial committees, 8o-82.

legal education and experience, 58-59.

organization, $80-82$.

presiding, $8 \mathrm{I}-82$.

jurisdiction of, 36-37.

jury

selection, 120-I 21 .

use of, 127 .

mental division, I86-193, 2 I6.

child study clinic, 186.

public administrators, $130-13 \mathrm{I}$. records, personnel in charge of,

I 40-I 4I.

referees, 105-106.

Probate courts in Detroit metropolitan district. See also Probate court.

jurisdiction of, $36-37$.

Probation

in outlying courts, 170 .

use of, I 56, I64-165, I69-170,

I7 1 .

Probation departments, 149-I72 circuit court, 152-156.

city justice courts, outside Detroit, I70-17I.

duplication, 270 .

juvenile court, 165-170.

recorder's court, I 56-165. 
Probationer, relationship with probation officer, I55-I 56. See also Probation.

Process, I3I-135.

Pro confesso docket, circuit court, 197 . Friend of the Court, 177, 197. See also Divorce.

Prosecutor. See Attorneys; County prosecutor.

in misdemeanor and felony cases, I08-II3, II7.

in traffic and ordinance court, I I 3-I I 4.

"Protected record" at juvenile court, 38-39, I62, I67-168, 238-240.

Providence Hospital, 255.

Psychiatrist. See also Sanity commission; Psychopathic clinic. report of, I I 9 .

use of, by circuit court probation officer, $\mathrm{I} 8 \mathrm{I}$.

Psychopathic clinic, recorder's court, $18 \mathrm{I}-183,235-236$.

Public administrators, I30-I3I. Public welfare,

Detroit department of, I92, 250, 260 .

State Department of, 249 .

Qualifications, of judges, 56-62. Quasi-judicial personnel in Detroit metropolitan district, IOO-IO6, 275-282.

circuit court commissioners, IOO-ror.

Friend of the Court, Ior. referees, I0I-106. total, 106-107.

Real estate, jurisdiction of circuit court commissioners, 34 .

Reconciliation, Friend of the Court, I 73-I 74.

Recorder's Court of the City of Detroit. See also Traffic and Ordinance Court. cases

age of, 207-2I4. bail, $207-208$. jail, 208-2I I.

disposed of prior to, or without, trial with full legal safeguards, 2I4-218. total load, 23 .

co-operation with welfare agencies, 259-260.

counsel, I08-II2, II 7 .

defense counsel

assigned, lo9-I I r .

in felony cases, 108-113.

in misdemeanor cases, 108 .

docket, machinery for handling, 199-203.

examinations, preliminary, I99.

felonies, 200-203. presiding judge, 82-87, 200 . judges

age of, 63 .

compensation of, $69-70$.

executive judge, 85 .

hours of service, 94-95.

legal education and experience, 59-6o.

organization of, 82-86. presiding judge, $82-84$. qualifications of, 59-60. selection of, 64-65. jurisdiction of, $44-46$. historical development, 4445. jury

selection of, I2 I-I 22.

use of, $123-126$.

personnel for official court records, I42-I45.

probation department, I44I45, I 56-I 65 .

prosecutors, 108-1 12, I 17 . psychopathic clinic, I44, I8II 83 .

quasi-judicial personnel, Io6. "quick justice," I I 2-I I3. 
Records, personnel in charge of, I $37-147$.

Referees, IoI-I06. See also Quasi-judicial personnel in Detroit metropolitan district.

Register

juvenile court, I4I-I 42. probate court, I4O-I4I.

Reporters, court, 136.

Reports, court, I47-I 50.

Restitution, collection of, I54I 55 .

Retirement of judges, 63 .

Salary. See Compensation.

Salvation Army, 254.

Sanity commission, required in murder cases, I 19, 212.

Sanity, restoration of jurisdiction of probate court, 36.

probate court practice, I9II92.

Scope of survey, I-3o.

Secret marriages, jurisdiction of probate court, 36 .

Simes, Lewis M., preface by, XIXIII.

Small claims. See also Court of Common Pleas of the City of Detroit; Circuit Court of Wayne County.

overlapping jurisdiction, 219$22 \mathrm{I}$.

Social agencies

active case load, 30 .

private, XIII, 250.

co-operation with courts, 250-267.

public, XIII

co-operation with courts, $250-267$.

number and character of, 249-250.

referral to pre-court adjustment division, recorder's court, 158.
Social problems. See also Family, problems.

related to use of large administrative agencies by metropolitan courts, 15 .

typical of metropolitan court case load, r6-3o.

Social Welfare, Department of, Wayne County

mental cases, I88-192, 249, 260.

Sociolegal problems, in metropolitan courts, 268 .

Special divisions

circuit court, I96-197.

conciliation division, court of common pleas, 88-90.

recorder's court, 82-87, 92 .

relation to specialized courts, 92-93.

use of, in Detroit, 9I-93.

Specialized courts. See also Special divisions.

court of common pleas, 48-50.

juvenile court, 37 .

traffic and ordinance court, 46-47.

Specialized judges, VIII, I4-15. See also Judges; One-man grand jury ; Presiding judge. circuit court, $75-80$.

conciliation division, court of common pleas, 88-9o.

juvenile court, 82 .

probate court, $80-82$.

recorder's court, 82-86.

misdemeanor division, $85-$ 86.

traffic and ordinance court, 86-87.

use of, in Detroit, 9I-93.

Staffs, court. See Personnel.

State Department of Public Welfare, 249.

Statistics

circuit court, I 48 .

court of common pleas, 149 . 
Statistics (continued)

Judicial Council of State of Michigan, I47-I 48 .

juvenile court, I 48-I49.

lack of integration, $149,270$.

police department, 148 .

probate court, I48-I 49 .

recorder's court, 148 .

state association of circuit judges, I 48 .

United States Bureau of the Census, $\mathrm{r} 48$.

Subject matter, jurisdiction over, 219-232.

Summation, 268-27o.

Sunderland, Edson R., XIII.

Supervision

by probation department, circuit court, I 53.

by probation department, recorder's court, I 59-I65.

of families

inadequate co-operation between courts, 244-245.

inadequate co-operation between courts and social agencies, I 49-I 72 .

use of court administrative agencies for, 15-16, 149I72.

Supervisory functions, of court administrative agencies, I49I 72.

Support. See also Family, support.

of illegitimate children, 33,36 . of indigents, by relatives, 37 . See also Aid, to dependent parents.

Township justices, size of staffs, I 4.

Township justices in Detroit metropolitan district, 5 . compensation of, $7 \mathrm{r}$. judicial organization of, 909 I. jurisdiction of, $52-55$. qualifications of, 62 . selection of, 66 .

Traffic

cases, characteristic of metropolitan courts, I 8-20, 268.

noises, metropolitan court problem, I92-I 93.

offenders, juvenile, 42 . offenses, 47.

Traffic and Ordinance Court of the City of Detroit

case load, 20.

counsel in, II3-II4.

docket, 203-204.

judges

age of, 63 .

case load per, 97-98.

compensation of, 70 .

hours of service, 96 .

legal education and experience of, 60 .

organization of, 86-87.

presiding judge, 86-87.

selection of, 65 .

jurisdiction, 46-47.

jury

selection of, I 22.

use of, 126 .

personnel for court records, I $45-146$.

referees, IOI-IO2.

relation to recorder's court, 46 47. See also Recorder's Court of the City of Detroit.

Trial, disposition of cases without, 214-2I5.

Trial, juries. See Juries.

Trial calendar, circuit court, 195-196.

Trial de novo, on appeal, overlapping jurisdiction, 222.

Trustee, Friend of the Court, I77.

Unconstitutional

Criminal Sexual Psychopathic Act, I I 8-119. 
Unconstitutional (continued) deprivation of defendant's rights, psychiatrist's report, I I 9.

Domestic Relations Court of Wayne County, 26.

"protected record," 239.

separate juvenile court in Wayne County, 37.

use of probation or psychopathic clinic report prior to determination of guilt, 156 I 57.

Violation Bureau

Dearborn, I35.

Detroit, I 45 .

Visiting judges, in Wayne County, 74-75, 234-235.

Volunteers of America, 254.

Wayne Community Survey, 255. Wayne County. See also under specific courts, agencies, and units.

board of jury commissioners, I I9-I 20.

use of, by circuit court commissioners, I 20.

use of, by court of common pleas, I2I.

courts

complement of, 32 .

historical development of, 9-IO.
Wayne County Department of Social Welfare, I92, 249250, 260.

Wayne County General Hospital, mental cases, I88, 25 I.

Wayne County jail, population, $207 \mathrm{ff}$.

Wayward minors

jurisdiction

juvenile court, 40-41. overlapping, defective, and conflicting, 227-23r.

metropolitan problem, 4I.

Welfare agencies

aid to dependent parents, 258 259.

central registration bureau, 264-267.

in Detroit, operative relationship with courts, 219-267. See also Domestic Relations; Family; Social agencies.

overlap with courts, 267 .

private, 250 .

co-operation with courts, 250-267.

public, 249-250.

Women's division, police department, 214, 237, 25I-253, 256.

Women's section, probation department, recorder's court, I60-I63. 